Prepared in cooperation with the Oklahoma Water Resources Board

\title{
Hydrogeology and Simulation of Groundwater flow In the Central Oklahoma (Garber-Wellington) Aquifer, OKathoma, 1987 to 2009, and Simulation of Available Water in Storage, 2010-2059
}

Scientific Investigations Report 2013-5219

Version 2.0, October 2019

U.S. Department of the lnterior

U.S. Geological Survey 
Cover. Lake Arcadia, Oklahoma, autumn 2010.

Back cover. Left: Waterfall near Guthrie, Oklahoma, autumn 2009.

Upper right: Jessica Correll, Oklahoma Water Resources Board, autumn 2010.

Lower right: Edmond Water Treatment Facility 2 in Arcadia, Oklahoma, autumn 2010.

All photographs by Christopher R. Neel, Oklahoma Water Resources Board. 


\section{Hydrogeology and Simulation of Groundwater Flow in the Central Oklahoma (Garber-Wellington) Aquifer, Oklahoma, 1987 to 2009, and Simulation of Available Water in Storage, 2010-2059}

By Shana L. Mashburn, Derek W. Ryter, Christopher R. Neel, S. Jerrod Smith, and Jessica S. Correll

Prepared in cooperation with the Oklahoma Water Resources Board

Scientific Investigations Report 2013-5219

Version 2.0, October 2019 


\title{
U.S. Department of the Interior DAVID BERNHARDT, Secretary
}

\section{U.S. Geological Survey James F. Reilly II, Deputy Director}

\author{
U.S. Geological Survey, Reston, Virginia: 2014 \\ First release: 2014, online and in print \\ Revised: April 2018 (ver 1.1), online \\ Revised: October 2019 (ver 2.0), online
}

\begin{abstract}
For more information on the USGS - the Federal source for science about the Earth, its natural and living resources, natural hazards, and the environment-visit https://www.usgs.gov or call 1-888-ASK-USGS.

For an overview of USGS information products, including maps, imagery, and publications, visit https://store.usgs.gov.
\end{abstract}

Any use of trade, firm, or product names is for descriptive purposes only and does not imply endorsement by the U.S. Government.

Although this information product, for the most part, is in the public domain, it also may contain copyrighted materials as noted in the text. Permission to reproduce copyrighted items must be secured from the copyright owner.

Suggested citation:

Mashburn, S.L., Ryter, D.W., Neel, C.R., Smith, S.J., and Correll, J.S., 2014, Hydrogeology and simulation of groundwater flow in the Central Oklahoma (Garber-Wellington) Aquifer, Oklahoma, 1987 to 2009, and simulation of available water in storage, 2010-2059 (ver. 2.0, October 2019): U.S. Geological Survey Scientific Investigations Report 2013-5219, 92 p., https://doi.org/10.3133/sir20135219. 


\section{Acknowledgments}

The authors wish to thank the Garber-Wellington Study Team, which included the authors of this report and John Harrington (Association of Central Oklahoma Governments), Scott Bowen (Tinker Air Force Base), Neil Suneson (Oklahoma Geological Survey), Scott Christenson [U.S. Geological Survey (USGS) Emeritus], Stanley Paxton (USGS), and Noel Osborn [National Park Service, formerly USGS and formerly Oklahoma Water Resources Board (OWRB)]. This Garber-Wellington Study Team met several times per year during the initial planning and implementation phase to discuss study progress and plans, and took several field trips to outcrops of the aquifer geologic units in the study area. The authors thank the City of Norman for providing access to production wells; Brian Hapke, Chris Mattingly, and Scott Aynes were gracious in assisting the field team for the study. Fred Rice and Sam Drain with the City of Edmond provided water-use data and access to production wells. The authors wish to thank additional OWRB scientists who helped collect data for the investigation described in this report: Theda Adkisson, Gene Dousset, Chris Maggard, Maria Moreno, Jason Shievers, and Rick Wicker. The authors extend their thanks to the many landowners who provided access to their property for hydrologic data collection.

The authors wish to thank several USGS scientists involved in the data collection for the investigation described in this report and the authors wish to acknowledge them individually: Jason Lewis, Kevin Smith, Rachel Esralew (currently U.S. Fish and Wildlife Service, formerly USGS), and former USGS students Greg Helling and Rika Burr. 


\section{Contents}

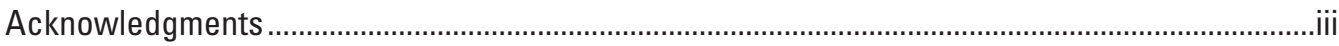

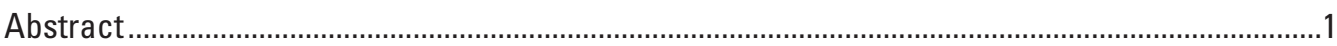

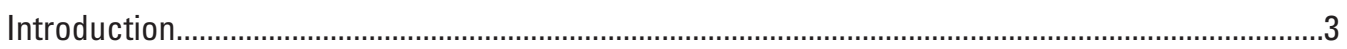

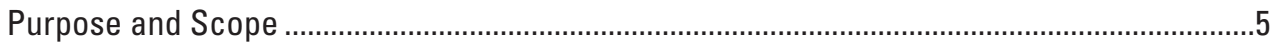

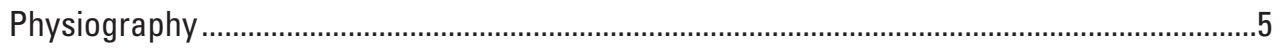

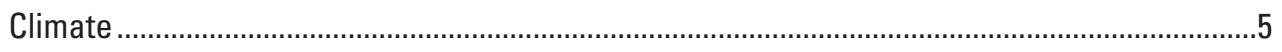

Geology of the Central Oklahoma Aquifer ..............................................................................

Geologic History and Depositional Environments .....................................................................

Quaternary-Age Alluvium and Terrace Deposits.....................................................................10

Permian-Age Geologic Units ...................................................................................... 10

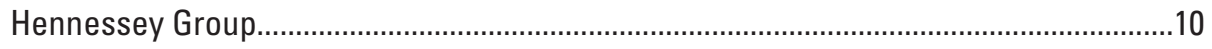

Garber Sandstone and Wellington Formation..............................................................10

Chase, Council Grove, and Admire Groups ....................................................................13

Pennsylvanian-Age Geologic Units ................................................................................13

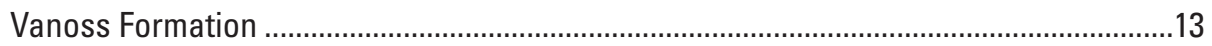

Characteristics of the Central Oklahoma Aquifer ……...............................................................

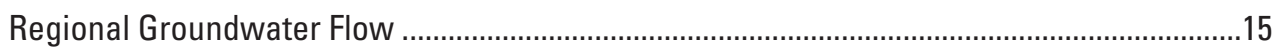

1986-87 Potentiometric Surface ...............................................................................15

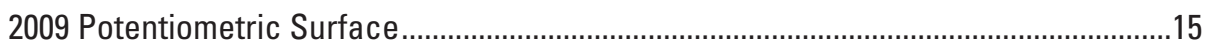

Comparison of Water Levels from 1986-87 to 2009.......................................................18

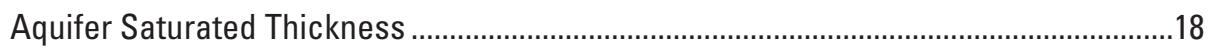

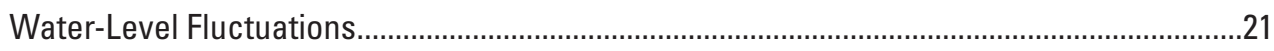

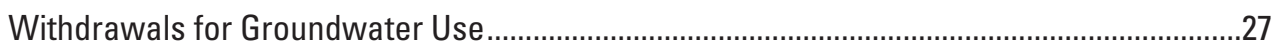

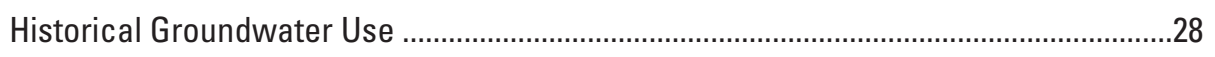

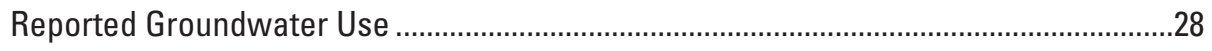

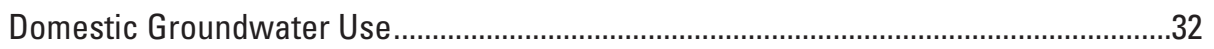

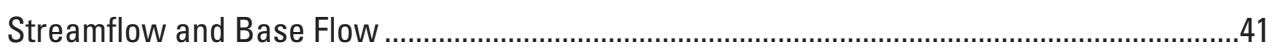

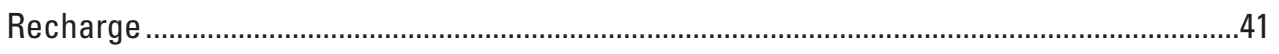

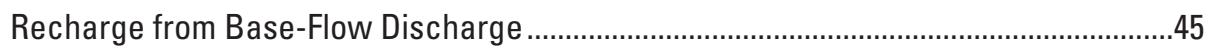

Recharge from Rorabaugh Method .............................................................................46

Recharge Calculated Using the Soil-Water Balance Code ............................................48

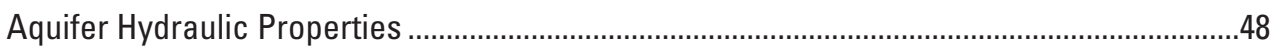

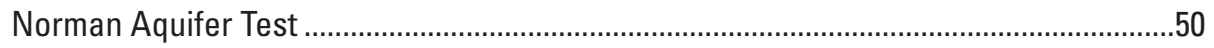

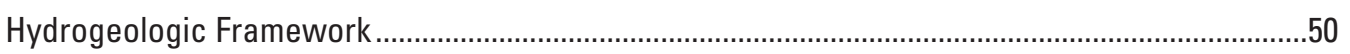

Percent Sand Data Sources and Standardization Methods .................................................50

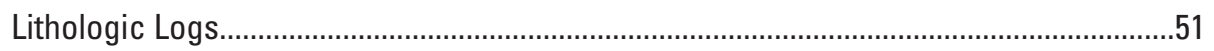

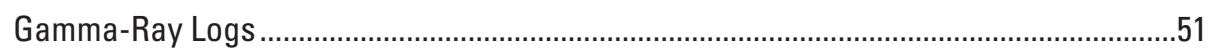

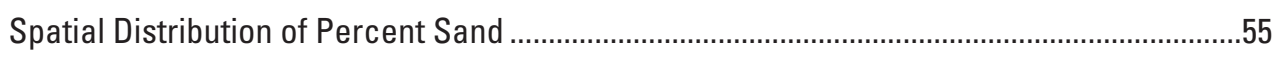

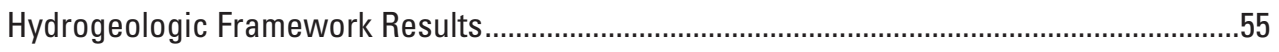

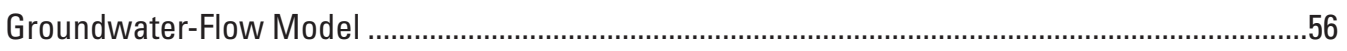

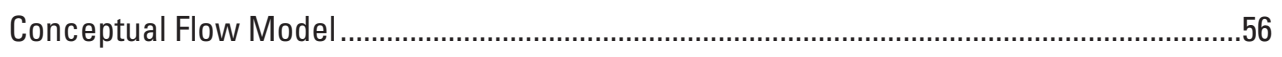

Numerical Groundwater-Flow Model Construction................................................................57 


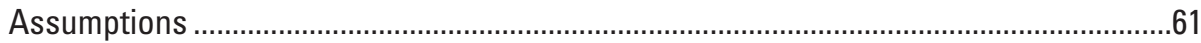

Simulation Periods

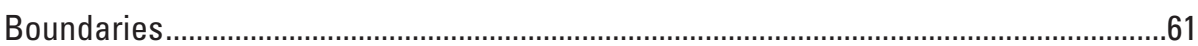

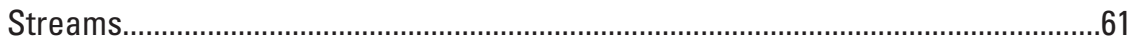

Lakes

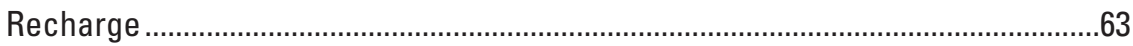

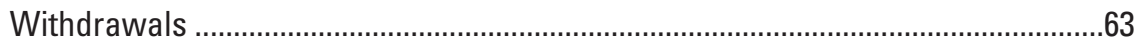

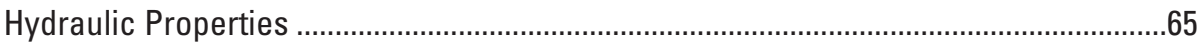

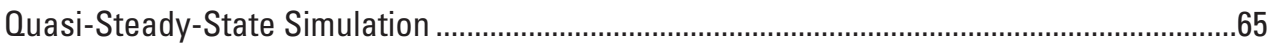

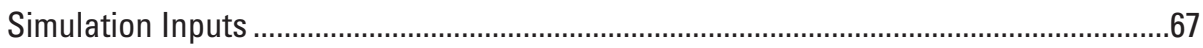

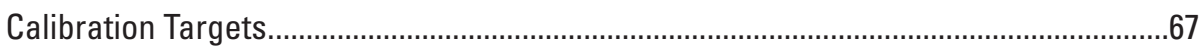

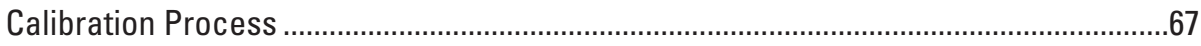

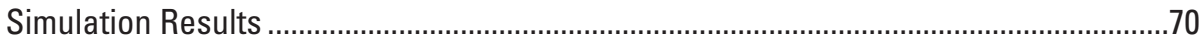

Transient Simulation 1987-2009..................................................................................

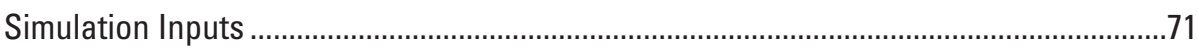

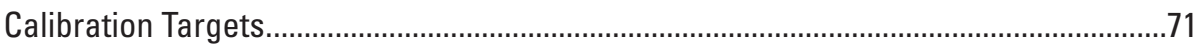

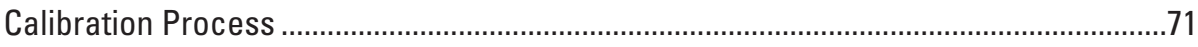

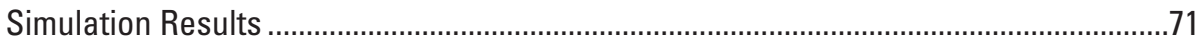

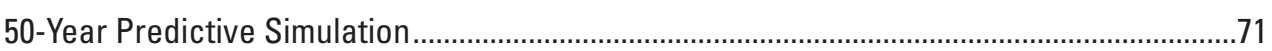

Simulation Inputs ....................................................................................................

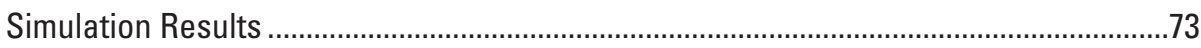

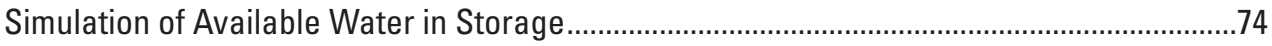

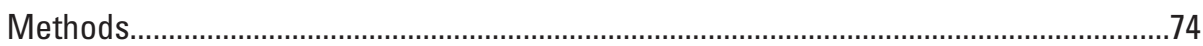

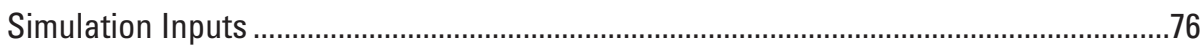

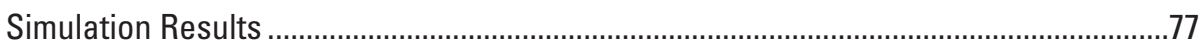

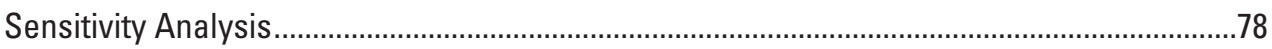

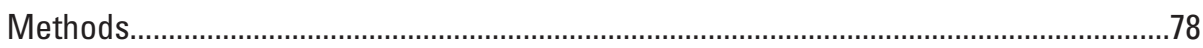

Sensitivity Analysis Results .................................................................................78

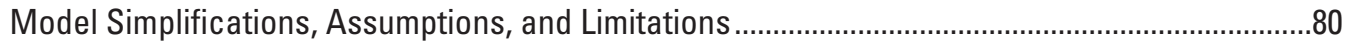

Summary

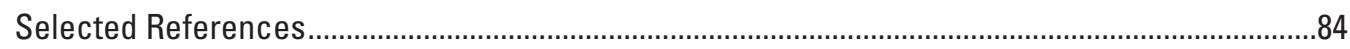

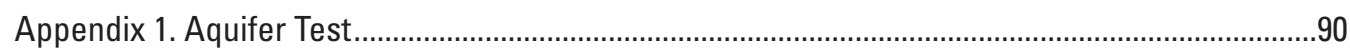

\section{Figures}

1. Map showing Central Oklahoma aquifer location, counties, cities, continuousrecorder wells, periodic water-level wells, cooperative observer stations, and Mesonet weather stations

2. Graph showing annual precipitation 1893-2009, 5-year moving average, and the number of cooperative observer stations recording during each year in the Central Oklahoma aquifer study area..

3. Graph showing the average monthly precipitation during the time periods 1950-1979 and 1980-2009 for cooperative observer stations in the Central Oklahoma aquifer study area

4. Map showing surficial geologic units in the extent of the Central Oklahoma aquifer.. 
5. Cross-section $A-A^{\prime}$ diagram showing bedrock geologic units of the Central Oklahoma aquifer.

6. Map showing the altitude of the base of the Hennessey Group (Hennessey confining unit)

7. Map showing the altitude of the base of the Wellington Formation.

8. Map showing the altitude of the base of the combined Chase, Council Grove, and Admire Groups.

9. Map showing potentiometric-surface contours (1986-87) and direction of groundwater flow in the Central Oklahoma aquifer.......

10. Map showing potentiometric-surface contours (2009) and direction of groundwater flow in the Central Oklahoma aquifer.

11. Map showing altitude of the base of fresh groundwater.

12. Map showing saturated thickness (2009) in the Central Oklahoma aquifer. .20

13. Graphs showing water levels from Oklahoma Water Resources Board Mass Measurement Program wells showing possible long-term (greater than 10 years) precipitation response in the Central Oklahoma aquifer area.....

14. Graphs showing water levels from Oklahoma Water Resources Board Mass Measurement Program wells showing possible response from localized groundwater pumping in the Central Oklahoma aquifer area.

15. Graph showing water levels from USGS wells showing possible pumping and precipitation responses in the Central Oklahoma aquifer area.

16. Graphs showing water levels from Oklahoma Water Resources Board continuous recorder wells showing possible long-term precipitation response in the Central Oklahoma aquifer area

17. Graphs showing water levels from Oklahoma Water Resources Board continuous recorder wells showing possible response from localized groundwater pumping in the Central Oklahoma aquifer area.

18. Graph showing water levels collected with a vented pressure transducer at Oklahoma Water Resources Board well site 94941 and atmospheric pressure measured at the Norman Mesonet Station in the Central Oklahoma aquifer...

19. Graph showing groundwater use from alluvium and bedrock sources in the Central Oklahoma aquifer, 1967-2008.

20. Graph showing groundwater use and estimated unreported use by type from the Central Oklahoma aquifer, 1967-2008.

21. Pie diagram showing average groundwater use by type from the Central Oklahoma aquifer, 1995-2008.

22. Map showing average annual reported groundwater use by permitted user greater than 100 acre-feet/year from the Central Oklahoma aquifer, 1995-2008 ............33

23. Graph showing groundwater use by the City of Edmond from 1967-2008 .......................34

24. Map showing population served by domestic wells during the year $1990 \ldots \ldots \ldots \ldots \ldots \ldots . . . . .35$

25. Map showing percent change in population from 1980 to 1990 ......................................36

26. Map showing percent change in population from 1990 to 2000 .......................................3

27. Map showing estimated population served by domestic wells during the year 2000

28. Map showing estimated population served by domestic wells during the year 2010

29. Graph showing estimated domestic use derived for the Central Oklahoma aquifer from the 1980, 1990, 2000, and 2010 U.S. Census Bureau data 
30. Map showing U.S. Geological Survey streamflow-gaging stations and selected surface-water basins and groundwater basins in the Central Oklahoma aquifer

31. Graph showing estimated quarterly recharge rates and average annual recharge rate using the Rorabaugh method for the Deep Fork River near Arcadia, Oklahoma basin for the period 1969 to 1983

32. Graph showing estimated quarterly recharge rates and average annual recharge rate using the Rorabaugh method for the Little River near Tecumseh, Oklahoma basin for the period 1943 to 1961

33. Map showing average annual recharge calculated using the Soil-Water-Balance code for the Central Oklahoma aquifer for the period 1987-2009 in 3,280-ft by 3,280-ft grid cells.

34. Diagram showing lithologic category bins for converting lithologic logs into percent sand

35. Map showing locations of lithologic logs and gamma-ray logs used for hydrogeologic framework percent-sand analysis of the Central Oklahoma aquifer

36. Bar charts showing distribution of depths of lithologic logs and gamma-ray logs used for hydrogeologic framework percent-sand analysis in the Central Oklahoma aquifer.

37. Graph showing scaling technique used to convert a gamma-ray log into percent sand for hydrogeologic framework percent-sand analysis in the Central Oklahoma aquifer.

38. Cross-section $A-A^{\prime}$ diagram showing layers for which percent sand was interpolated in the hydrogeologic framework of the Central Oklahoma aquifer

39. Map showing interpolated percent sand and log locations for layers 1 through 5 for the hydrogeologic framework and for layers 6 through 11 for the hydrogeologic framework

40. Bar charts showing derived percent sand distributions from lithologic logs and gamma-ray logs

41. Map showing numerical groundwater-flow model grid and boundary conditions for the Central Oklahoma aquifer study.

42. Map showing stream channel widths and wells from which reported use was simulated in the transient groundwater-flow model for the Central Oklahoma aquifer.

43. Map showing depths from land surface that estimated domestic use was withdrawn for the transient groundwater-flow model for the Central Oklahoma aquifer

44. Block diagram of horizontal hydraulic conductivity per model cell viewed from the southwest and truncated at model row 70 , showing higher conductivity in the center of the aquifer and the low conductivity of the Hennessey Group on the west.

45. Histogram of the distribution of head targets by model layer.........................................68

46. Map showing targets and residuals for the quasi-steady-state model for 1986-87 measurements

47. Graph showing simulated as compared to observed heads in the quasi-steady-state model for 1986-87 measurements.

48. Histogram of residuals from the head targets in the quasi-steady-state model for 1986-87 measurements 
49. Map showing head residuals and error for the last stress period of the transient model, 1987-2009

50. Graph showing simulated as compared to observed heads in the transient model, 1987-2009

51. Histogram of residuals from the head targets in the transient model, 1987-2009 ..........73

52. Bar charts showing water budget for the transient model showing total flux for the period 1987-2009, by boundary condition.

53. Map showing drawdown in the Central Oklahoma aquifer numerical model after 50 years with 2009 pumping rates compared to the aquifer with no pumping....

54. Graph showing 50-year predictive model budget showing recharge, water removed from storage, groundwater pumpage, and base flow to streams assuming constant recharge and pumping at estimated 2009 rates

55. Graph showing percent of aquifer that had less than or equal to 15 feet of saturated thickness at various pumping rates at the end of a 50 -year period (scenario 1)

56. Maps showing Central Oklahoma aquifer altitude of the water table (head) after 1, 25 , and 50 years of pumping for the 2009-58 depletion-scenario simulation

57. Graph showing percent of aquifer that had less than or equal to 15 feet of saturated thickness at a pumping rate of 2.0 (acre-feet per acre) per year (scenario 2)

58. Graph showing changes in simulated heads at head targets in the transient model with percent changes in selected model parameters.

1-1. Schematic diagram showing layout of the aquifer test in the Central Oklahoma aquifer.

1-2. Graph showing the deep observation well water-level during the pumping (March 1-8) and recovery periods (March 8-16) of the Norman aquifer test in the Central Oklahoma aquifer, 2011

1-3. Graphs showing pumping drawdown data curves and derivatives with best-fit Hantush method with aquitard storage solution for leaky confined aquifer analysis

1-4. Graph showing water-level recovery data in Agarwal equivalent time with best-fit curve for the recovery analysis 


\section{Tables}

1. Data collection time periods of precipitation at the cooperative observer stations used in the Central Oklahoma aquifer study area..............................................

2. Stratigraphic column of geologic and hydrogeologic units in the Central Oklahoma aquifer...

3. Reported and estimated groundwater-use statistics for the Central Oklahoma aquifer, 1967-2008.

4. Average annual reported and estimated groundwater use by type for the Central Oklahoma aquifer, 1967-2008...

5. Largest users of groundwater from the Central Oklahoma aquifer from 1995 to 2008 .

6. Cumulative population data and estimated domestic water use derived from the 1980, 1990, 2000, and 2010 census for the Central Oklahoma aquifer.

7. Streamflows at USGS streamflow-gaging stations in the vicinity of the Central Oklahoma aquifer summarized through 2009.

8. Streamflow measurements (at base flow) and calculated recharge rates from small selected streams located near the Central Oklahoma aquifer

9. Water budget and inflow-outflow discrepancy for the transient model

10. Hydraulic properties, storage properties, and available water in storage at the end of the transient simulation of the Central Oklahoma (Garber-Wellington) aquifer, 1987-2009.

11. Sensitivity of simulated heads to changes in parameters in the transient model...........80 


\section{Conversion Factors}

This report contains a mixture of inch/pound and System International (SI) units. The water management in Oklahoma traditionally works in acre-feet units, whereas the numerical groundwater-flow model was built in SI units. Measurements and calculations are reported in units appropriate to the subject under discussion and not converted to one system of units.

Inch/Pound to SI

\begin{tabular}{|c|c|c|}
\hline Multiply & By & To obtain \\
\hline \multicolumn{3}{|c|}{ Length } \\
\hline inch (in.) & 2.54 & centimeter $(\mathrm{cm})$ \\
\hline foot $(\mathrm{ft})$ & 0.3048 & meter $(\mathrm{m})$ \\
\hline mile (mi) & 1.609 & kilometer (km) \\
\hline \multicolumn{3}{|c|}{ Area } \\
\hline acre & 4,047 & square meter $\left(\mathrm{m}^{2}\right)$ \\
\hline acre & 0.004047 & square kilometer $\left(\mathrm{km}^{2}\right)$ \\
\hline square foot $\left(\mathrm{ft}^{2}\right)$ & 929.0 & square centimeter $\left(\mathrm{cm}^{2}\right)$ \\
\hline square foot $\left(\mathrm{ft}^{2}\right)$ & 0.09290 & square meter $\left(\mathrm{m}^{2}\right)$ \\
\hline square inch $\left(\mathrm{in}^{2}\right)$ & 6.452 & square centimeter $\left(\mathrm{cm}^{2}\right)$ \\
\hline section ( 640 acres or 1 square mile) & 259.0 & square hectometer $\left(\mathrm{hm}^{2}\right)$ \\
\hline square mile $\left(\mathrm{mi}^{2}\right)$ & 259.0 & hectare (ha) \\
\hline square mile $\left(\mathrm{mi}^{2}\right)$ & 2.590 & square kilometer $\left(\mathrm{km}^{2}\right)$ \\
\hline \multicolumn{3}{|c|}{ Volume } \\
\hline gallon (gal) & 0.003785 & cubic meter $\left(\mathrm{m}^{3}\right)$ \\
\hline million gallons (Mgal) & 3,785 & cubic meter $\left(\mathrm{m}^{3}\right)$ \\
\hline cubic foot $\left(\mathrm{ft}^{3}\right)$ & 28.32 & cubic decimeter $\left(\mathrm{dm}^{3}\right)$ \\
\hline cubic foot $\left(\mathrm{ft}^{3}\right)$ & 0.02832 & cubic meter $\left(\mathrm{m}^{3}\right)$ \\
\hline acre-foot (acre-ft) & 1,233 & cubic meter $\left(\mathrm{m}^{3}\right)$ \\
\hline \multicolumn{3}{|c|}{ Flow rate } \\
\hline acre-foot per day (acre-ft/d) & 0.01427 & cubic meter per second $\left(\mathrm{m}^{3} / \mathrm{s}\right)$ \\
\hline acre-foot per year (acre-ft/yr) & 1,233 & cubic meter per year $\left(\mathrm{m}^{3} / \mathrm{yr}\right)$ \\
\hline acre-foot per year (acre-ft/yr) & 0.001233 & cubic hectometer per year $\left(\mathrm{hm}^{3} / \mathrm{yr}\right)$ \\
\hline foot per second $(\mathrm{ft} / \mathrm{s})$ & 0.3048 & meter per second $(\mathrm{m} / \mathrm{s})$ \\
\hline foot per day (ft/d) & 0.3048 & meter per day $(\mathrm{m} / \mathrm{d})$ \\
\hline foot per year (ft/yr) & 0.3048 & meter per year (m/yr) \\
\hline cubic foot per second $\left(\mathrm{ft}^{3} / \mathrm{s}\right)$ & 0.02832 & cubic meter per second $\left(\mathrm{m}^{3} / \mathrm{s}\right)$ \\
\hline cubic foot per day $\left(\mathrm{ft}^{3} / \mathrm{d}\right)$ & 0.02832 & cubic meter per day $\left(\mathrm{m}^{3} / \mathrm{d}\right)$ \\
\hline gallon per minute (gal/min) & 0.06309 & liter per second $(\mathrm{L} / \mathrm{s})$ \\
\hline gallon per day (gal/d) & 0.003785 & cubic meter per day $\left(\mathrm{m}^{3} / \mathrm{d}\right)$ \\
\hline million gallons per day (Mgal/d) & 0.04381 & cubic meter per second $\left(\mathrm{m}^{3} / \mathrm{s}\right)$ \\
\hline inch per year (in/yr) & 25.4 & millimeter per year (mm/yr) \\
\hline \multicolumn{3}{|c|}{ Specific capacity } \\
\hline gallon per minute per foot $[(\mathrm{gal} / \mathrm{min}) / \mathrm{ft})]$ & 0.2070 & liter per second per meter $[(\mathrm{L} / \mathrm{s}) / \mathrm{m}]$ \\
\hline \multicolumn{3}{|c|}{ Hydraulic conductivity } \\
\hline feet per day (ft/d) & 0.3048 & meter per day $(\mathrm{m} / \mathrm{d})$ \\
\hline \multicolumn{3}{|c|}{ Transmissivity* } \\
\hline foot squared per day $\left(\mathrm{ft}^{2} / \mathrm{d}\right)$ & 0.09290 & meter squared per day $\left(\mathrm{m}^{2} / \mathrm{d}\right)$ \\
\hline
\end{tabular}


SI to Inch/Pound

\begin{tabular}{|c|c|c|}
\hline Multiply & By & To obtain \\
\hline \multicolumn{3}{|c|}{ Length } \\
\hline centimeter $(\mathrm{cm})$ & 0.3937 & inch (in.) \\
\hline millimeter $(\mathrm{mm})$ & 0.03937 & inch (in.) \\
\hline meter $(\mathrm{m})$ & 3.281 & foot $(\mathrm{ft})$ \\
\hline kilometer $(\mathrm{km})$ & 0.6214 & mile (mi) \\
\hline \multicolumn{3}{|c|}{ Area } \\
\hline square meter $\left(\mathrm{m}^{2}\right)$ & 0.0002471 & acre \\
\hline square hectometer $\left(\mathrm{hm}^{2}\right)$ & 2.471 & acre \\
\hline square kilometer $\left(\mathrm{km}^{2}\right)$ & 247.1 & acre \\
\hline square centimeter $\left(\mathrm{cm}^{2}\right)$ & 0.001076 & square foot $\left(\mathrm{ft}^{2}\right)$ \\
\hline square meter $\left(\mathrm{m}^{2}\right)$ & 10.76 & square foot $\left(\mathrm{ft}^{2}\right)$ \\
\hline square centimeter $\left(\mathrm{cm}^{2}\right)$ & 0.1550 & square inch $\left(\mathrm{ft}^{2}\right)$ \\
\hline square hectometer $\left(\mathrm{hm}^{2}\right)$ & 0.003861 & section (640 acres or 1 square mile) \\
\hline square kilometer $\left(\mathrm{km}^{2}\right)$ & 0.3861 & square mile $\left(\mathrm{mi}^{2}\right)$ \\
\hline \multicolumn{3}{|c|}{ Volume } \\
\hline liter $(\mathrm{L})$ & 0.2642 & gallon (gal) \\
\hline cubic meter $\left(\mathrm{m}^{3}\right)$ & 264.2 & gallon (gal) \\
\hline cubic meter $\left(\mathrm{m}^{3}\right)$ & 0.0002642 & million gallons (Mgal) \\
\hline cubic meter $\left(\mathrm{m}^{3}\right)$ & 35.31 & cubic foot $\left(\mathrm{ft}^{3}\right)$ \\
\hline cubic meter $\left(\mathrm{m}^{3}\right)$ & 0.0008107 & acre-foot (acre-ft) \\
\hline \multicolumn{3}{|c|}{ Flow rate } \\
\hline cubic meter per second $\left(\mathrm{m}^{3} / \mathrm{s}\right)$ & 70.07 & acre-foot per day (acre-ft/d) \\
\hline cubic meter per year $\left(\mathrm{m}^{3} / \mathrm{yr}\right)$ & 0.000811 & acre-foot per year (acre-ft/yr) \\
\hline meter per second $(\mathrm{m} / \mathrm{s})$ & 3.281 & foot per second (ft/s) \\
\hline meter per day $(\mathrm{m} / \mathrm{d})$ & 3.281 & foot per day $(\mathrm{ft} / \mathrm{d})$ \\
\hline meter per year $(\mathrm{m} / \mathrm{yr})$ & 3.281 & foot per year ft/yr) \\
\hline cubic meter per second $\left(\mathrm{m}^{3} / \mathrm{s}\right)$ & 35.31 & cubic foot per second $\left(\mathrm{ft}^{3} / \mathrm{s}\right)$ \\
\hline cubic meter per day $\left(\mathrm{m}^{3} / \mathrm{d}\right)$ & 35.31 & cubic foot per day $\left(\mathrm{ft}^{3} / \mathrm{d}\right)$ \\
\hline liter per second $(\mathrm{L} / \mathrm{s})$ & 15.85 & gallon per minute (gal/min) \\
\hline cubic meter per day $\left(\mathrm{m}^{3} / \mathrm{d}\right)$ & 264.2 & gallon per day $(\mathrm{gal} / \mathrm{d})$ \\
\hline cubic meter per second $\left(\mathrm{m}^{3} / \mathrm{s}\right)$ & 22.83 & million gallons per day (Mgal/d) \\
\hline millimeter per year (mm/yr) & 0.03937 & inch per year (in/yr) \\
\hline kilometer per hour $(\mathrm{km} / \mathrm{h})$ & 0.6214 & mile per hour $(\mathrm{mi} / \mathrm{h})$ \\
\hline \multicolumn{3}{|c|}{ Specific capacity } \\
\hline liter per second per meter $[(\mathrm{L} / \mathrm{s}) / \mathrm{m}]$ & 4.831 & $\begin{array}{l}\text { gallon per minute per foot } \\
{[(\mathrm{gal} / \mathrm{min}) / \mathrm{ft}]}\end{array}$ \\
\hline \multicolumn{3}{|c|}{ Hydraulic conductivity } \\
\hline meter per day $(\mathrm{m} / \mathrm{d})$ & 3.281 & foot per day (ft/d) \\
\hline \multicolumn{3}{|c|}{ Transmissivity* } \\
\hline meter squared per day $\left(\mathrm{m}^{2} / \mathrm{d}\right)$ & 10.76 & foot squared per day $\left(\mathrm{ft}^{2} / \mathrm{d}\right)$ \\
\hline
\end{tabular}


Vertical coordinate information is referenced to the North American Vertical Datum of 1988 (NAVD 88). The NAVD 88 replaced the National Geodetic Vertical Datum of 1929 (NGVD 29), previously known as the Sea Level Datum of 1929.

Horizontal coordinate information is referenced to the North American Datum of 1983 (NAD 83).

Altitude, as used in this report, refers to distance above the vertical datum.

Temperature in degrees Fahrenheit $\left({ }^{\circ} \mathrm{F}\right)$ may be converted to degrees Celsius $\left({ }^{\circ} \mathrm{C}\right)$ as follows:

${ }^{\circ} \mathrm{C}=\left({ }^{\circ} \mathrm{F}-32\right) / 1.8$

Water year is the 12-month period October 1 through September 30, designated by the calendar year in which the water year ends.

Concentrations of chemical constituents in water are given either in milligrams per liter (mg/L) or micrograms per liter $(\mu \mathrm{g} / \mathrm{L})$.

*Transmissivity: The standard unit for transmissivity is cubic foot per day per square foot times foot of aquifer thickness [(ft $\left.\left.\mathrm{ft}^{3} \mathrm{~d}\right) / \mathrm{ft}^{2}\right] \mathrm{ft}$. In this report, the mathematically reduced form, foot squared per day $\left(\mathrm{ft}^{2} / \mathrm{d}\right)$, is used for convenience. 


\title{
Hydrogeology and Simulation of Groundwater Flow in the Central Oklahoma (Garber-Wellington) Aquifer, Oklahoma, 1987 to 2009, and Simulation of Available Water in Storage, 2010-2059
}

\author{
By Shana L. Mashburn, Derek W. Ryter, Christopher R. Neel, S. Jerrod Smith , and Jessica S. Correll
}

\section{Abstract}

The Central Oklahoma (Garber-Wellington) aquifer underlies about 3,000 square miles of central Oklahoma. The study area for this investigation was the extent of the Central Oklahoma aquifer. Water from the Central Oklahoma aquifer is used for public, industrial, commercial, agricultural, and domestic supply. With the exception of Oklahoma City, all of the major communities in central Oklahoma rely either solely or partly on groundwater from this aquifer. The Oklahoma City metropolitan area, incorporating parts of Canadian, Cleveland, Grady, Lincoln, Logan, McClain, and Oklahoma Counties, has a population of approximately 1.2 million people. As areas are developed for groundwater supply, increased groundwater withdrawals may result in decreases in long-term aquifer storage. The U.S. Geological Survey, in cooperation with the Oklahoma Water Resources Board, investigated the hydrogeology and simulated groundwater flow in the aquifer using a numerical groundwater-flow model.

The purpose of this report is to describe an investigation of the Central Oklahoma aquifer that included analyses of the hydrogeology, hydrogeologic framework of the aquifer, and construction of a numerical groundwater-flow model. The groundwater-flow model was used to simulate groundwater levels and for water-budget analysis. A calibrated transient model was used to evaluate changes in groundwater storage associated with increased future water demands.

The Central Oklahoma aquifer consists of Quaternaryage alluvium and terrace deposits and the Permian-age Garber Sandstone, Wellington Formation, and Chase, Council Grove, and Admire Groups. Groundwater flows between these geologic units and many wells are completed in the Quaternaryage and Permian-age units in the study area. The investigation described in this report focused more on the Permian-age units because water in the Quaternary-age alluvium and terrace was volumetrically a small fraction compared to the Permian-age units.
Analysis of regional groundwater flows indicate that groundwater in the shallow, local flow systems discharge to nearby streams and the rate of flow and flux of water are greatest in these local flow systems. Flow in the deeper part of the aquifer is slower and flowlines are longer than in the shallow, local flow systems. In the deeper flow system, groundwater flows under small streams to discharge primarily to the Deep Fork River and Little River. Flow in the Central Oklahoma aquifer is slowest in the confined part of the Garber Sandstone and Wellington Formation and in the less transmissive parts of the unconfined flow system, which includes part of the Chase, Council Grove, and Admire Groups. Groundwater in the confined part of aquifer comes from recharge primarily from a small area of the unconfined part of the aquifer near $35^{\circ} 23^{\prime}$ latitude and $97^{\circ} 23^{\prime}$ longitude as shown by the mound of water on the potentiometric-surface maps.

Groundwater levels measured in this aquifer in 2009 were compared to water levels measured in 1986-87. Groundwater levels measured in wells in both the 1986-87 and 2009 time periods were compared (169 wells). The difference in the median depth-to-water measurements for the two time periods was a decline of 3.75 feet. A water-level decline of 3.75 feet multiplied by the area of the aquifer ( 3,000 square miles), multiplied by the minimum and maximum porosity expected for this aquifer (14 to 30 percent) indicated change of water in storage from 1986-87 to 2009 ranging from $1,008,000$ to $2,160,000$ acre-feet, assuming that all water from aquifer storage came from unconfined conditions. This loss in storage from 1986-2009 period, averaged per year, was about 44,000 to 94,000 acre-ft/yr.

Water levels from wells measured by the Oklahoma Water Resources Board Mass Measurement Program and in the U.S. Geological Survey National Water Information System database indicate that shallow wells are affected by barometric-pressure changes, precipitation, and pumping from nearby shallow wells. Water levels in deeper wells in the aquifer had minimal response to precipitation and barometricpressure changes, but responded to pumping from nearby deep wells. 
Groundwater-use data were compiled from annual water-use reports submitted by permit holders to the Oklahoma Water Resources Board. Including estimated unreported groundwater use, average groundwater use from 1967 to 2008 was about 37,367 acre-feet/year with public-water supply consuming 23,367 acre-feet/year, or about 63 percent of the average annual reported and estimated unreported groundwater use. Domestic groundwater use was estimated by using the 1990 census long-form data and population change compared to 1980, 2000, and 2010 census data. Average estimated domestic groundwater use from the aquifer from 1980 to 2010 was about 13,752 acre-feet/year.

Recharge rates to the Central Oklahoma aquifer were estimated or calculated using three methods that varied in spatial and temporal scales. Recharge rates were estimated by using a basin-scale base-flow-discharge method, a basinscale recession-curve displacement (Rorabaugh) method, and a regional-scale method using the Soil-Water Balance code. The Soil-Water Balance method was used to estimate initial recharge for the groundwater-flow model because this method estimates spatial distribution of recharge for the aquifer area. Average annual recharge from the Soil-Water Balance code for the gridded aquifer area for the 1987-2009 period was 4.6 inches. However, during model calibration, a scaling factor of 0.4 was applied to Soil-Water Balance recharge, which resulted in 1.84 inches per year of average annual recharge values for the gridded aquifer area for the 1987-2009 period.

Aquifer hydraulic properties were estimated from lithologic and geophysical well logs and a multiple-well aquifer test was analyzed to determine transmissivity and a storage coefficient. Transmissivity determined from the aquifer test at a production well near Norman, Oklahoma was 220 square feet per day. The geohydrologic-unit hydraulic conductivity was 2.4 feet per day. The storage coefficient from the analytical solution was 0.0013 . This storage coefficient indicates that, even though the Central Oklahoma aquifer extends to land surface with a potentiometric surface below the top of the Central Oklahoma aquifer, the groundwater system acts as a confined system due to laterally extensive interbedded mudstone and large contrasts in vertical hydraulic conductivity.

The objective of developing the hydrogeologic framework of the Central Oklahoma aquifer system was to provide a three-dimensional representation of the lithologic variability of aquifer materials at a scale that captured the regional controls on groundwater flow for input to the groundwater-flow model. Lithologic logs and gamma-ray logs were converted to percent sand, which was used as a proxy in the estimation of initial hydraulic conductivity of the aquifer for the groundwater-flow model.

A MODFLOW groundwater-flow model was developed to simulate groundwater flow and build water budgets in the Central Oklahoma aquifer. The Central Oklahoma aquifer was simulated using a grid comprised of 3,280-feet by 3,280-feet (1-kilometer by 1-kilometer) cells and 11 horizontal layers, each 100-feet thick (30.48 meters). The quasi-steadystate model was run to simulate the 1987 calendar year with equilibrium in flow and minimal changes in storage. Initial hydraulic conductivity used for the groundwater-flow model ranged from 0.33 to 3.3 feet per day and was estimated for each model cell using the percent sand from the hydrogeologic framework. The quasi-steady-state model was calibrated to a subset of the 1986-87 water levels. Parameters that were adjusted to affect quasi-steady-state model calibration included hydraulic conductivity, vertical anisotropy, and recharge. Recharge for the groundwater-flow model was set to 0.4 multiplied by the Soil-Water Balance recharge estimate. There was no apparent horizontal or vertical spatial bias to model error and the residuals indicated that the simulated hydraulic heads are slightly lower than the observed hydraulic heads, but most residuals were near zero. These results indicate that there is random error in the model, a large component of which is related to the discretization that could not accommodate local variation. Hydraulic heads in the aquifer have been well simulated using the spatial distribution of percent sand.

The transient groundwater-flow model was constructed to cover the period from 1987 through 2009. Because pumping rates for public water-supply wells were only available on annual intervals, each year was chosen as a stress period. The transient model was calibrated to all available water-level measurements for the aquifer during the period of the simulation (1987-2009). Parameters adjusted during the transient calibration process included the specific yield and specific storage of the aquifer, and the average annual recharge rate. The largest flux to the model is recharge, with water removed from storage, seepage from reservoirs, and water lost from the aquifer to streams being lesser amounts. Outflow is dominated by base flow to streams and pumping from wells. Water was removed from storage to meet the total outflow which indicates the aquifer was in a deficit (losing water) during this period. At the end of the transient simulation (2009), the aquifer mean saturated thickness was about 392 feet and the aquifer mean transmissivity was about 1,057 square feet per day. The simulated available water in storage was about 98.676 million acre-feet.

The purpose of the 50-year predictive simulation was to estimate the change in groundwater in storage if water use continues for 50 years at 2009 rates. The period of the predictive model was 2010 through 2059. The 50-year predictive simulation used the same model inputs as the calibrated transient model except for recharge and pumping. Because this study did not attempt to simulate effects from a predictive climate model, recharge was held constant at the average flux for each cell that was specified for the 1987-2009 time period. Pumping was held constant at the 2009 average daily discharge for each well. Estimation of the effect to water levels in the aquifer by continuously pumping at the 2009 pumping rate for 50 years was achieved by running the model without any pumping, and then running the model with pumping. The difference in hydraulic heads and water in storage between those model runs was used to estimate the effect of pumping to storage in the aquifer. Pumping at the 2009 rate for 50 years with constant recharge resulted in drawdown in upland areas and reduction of water 
in storage. The recharge rate was substantially higher than the total pumping rate, but water discharge to streams combined with pumping created a deficit that was met by releasing water from aquifer storage and decreasing base flow to streams.

The calibrated transient model also was run to determine how much water could hypothetically be extracted from the Central Oklahoma aquifer in a 50-year period (scenario 1), and the effect of pumping the temporary state-apportioned rate of 2.0 (acre-feet/acre)/year (scenario 2). The purpose of this analysis was to provide estimates of the amount of water in storage in the Central Oklahoma aquifer. These scenarios were used to simulate the equal proportionate share by placing a well in every model cell and pumping at a constant rate. The first scenario determined the discharge rate at which wells placed in every model cell would have to be pumped so that just 15 feet (4.57 meters) or less of saturated thickness remained in 50 percent of the aquifer area (50 percent of the model cells) after 50 years. The second scenario was to pump 2.0 (acre-feet/acre)/year from every model cell, and to determine the time at which one-half of the aquifer area was reduced to 15 feet or less of saturated thickness. For scenario 1, the pumping rate at all cells that reduced the saturated thickness in one-half of the cells to or below 15 feet (4.57 meters) after 50 years was between 1.1 and 1.5 (acrefeet/acre)/year. The results of scenario 2 indicate the aquifer would be 50 percent depleted after between 35 and 41 years of pumping 2.0 (acre-feet/acre)/year using 10 percent increase and decrease in specific yield. This analysis indicates that this pumping rate of 2.0 (acre-feet/acre)/year is not sustainable for more than 41 years if every landowner with a potential well in each acre in the Central Oklahoma aquifer exercised their temporary right to pump at that rate.

\section{Introduction}

The Central Oklahoma aquifer underlies about 3,000 square miles of central Oklahoma (fig. 1). Water from the Central Oklahoma aquifer is used for public, industrial, commercial, agricultural, and domestic supply (Parkhurst and others, 1996). With the exception of Oklahoma City (fig. 1), all of the major communities in central Oklahoma rely either solely or partly on groundwater from this aquifer (Oklahoma Water Resources Board, 2011). The Oklahoma City metropolitan area, incorporating parts of Canadian, Cleveland, Grady, Lincoln, Logan, McClain, and Oklahoma Counties (fig. 1), has a population of approximately 1.2 million people, estimated from the 2010 census (U.S. Census Bureau, 2010) and is expected to increase by 20 percent from 2000 to 2030 (Oklahoma Department of Commerce, 2012). Residential development also is moving into rural areas, resulting in increased groundwater withdrawals from areas with previous minimal development. As areas are developed for groundwater supply, increased groundwater withdrawals may result in decreases in long-term aquifer water storage.
As of 2013, the Oklahoma Water Resources Board (OWRB) had not determined the maximum annual yield of groundwater from the Central Oklahoma aquifer. The maximum annual yield of a groundwater basin is defined by the OWRB to be the total amount of fresh groundwater that can be withdrawn while allowing a minimum 20 -year life of a (groundwater) basin subsequent to that withdrawal (Oklahoma Water Resources Board, 2010). A groundwater basin is defined by the OWRB as "a distinct underground body of water by contiguous land having substantially the same geological and hydrological characteristics and yield capabilities." "Life of a groundwater basin or subbasin" is defined by the OWRB as "....that period of time during which at least fifty percent of the total overlying land of the basin or subbasin will retain a saturated thickness allowing pumping of the maximum annual yield for a minimum twenty-year life of such basin or subbasin, provided that after July 1, 1994, the average saturated thickness will be calculated to be maintained at five feet for alluvium and terrace aquifers and fifteen feet for bedrock aquifers unless otherwise determined by the Board [OWRB];...." (Oklahoma Water Resources Board, 2010). The average saturated thickness of an aquifer is determined through hydrologic investigations. After the maximum annual yield has been established, the amount of water allocated to each permit applicant will be proportionate to the amount of land owned or leased by that applicant. This amount of water is referred to as the landowner's equal proportionate share. For example, if a permit applicant owns 100 acres, and the equal proportionate share has been determined to be 1.5 (acre-feet/acre)/year, which is abbreviated in the remainder of this report as (acre-ft/acre)/yr, then that permit applicant is allocated 150 acre-feet per year. Oklahoma water law (Oklahoma Statutes Title 82 Section 1020.5, 2011) states that certain factors be considered in the determination of the maximum annual yield of a major groundwater basin: total land area overlying the basin, the amount of water in storage in the basin, the rate of recharge, and total discharge from the basin, transmissivity of the basin, and the possibility of pollution from natural sources.

To determine the maximum annual yield of a major groundwater basin, a hydrologic investigation is completed to obtain data and information related to the hydrology and hydrogeologic framework of the aquifer. Hydrologic data collected includes precipitation, water-level measurements, potentiometric-surface maps, measurements of transmissivity and storage coefficients, streamflow data, and geochemical data. Hydrogeologic framework data for this study consisted of lithologic properties extrapolated from gamma-ray logs and drillers' lithologic logs, base-of-formation maps, and baseof-freshwater maps. A numerical groundwater-flow model can be developed using these data and information from the hydrologic investigation to conceptualize the flow system and, in turn, to evaluate effects of water withdrawals on the aquifer. Until the hydrology has been investigated and a maximum annual yield determined for a groundwater basin, the OWRB grants temporary permits to users allocating 2.0 acre-feet of 


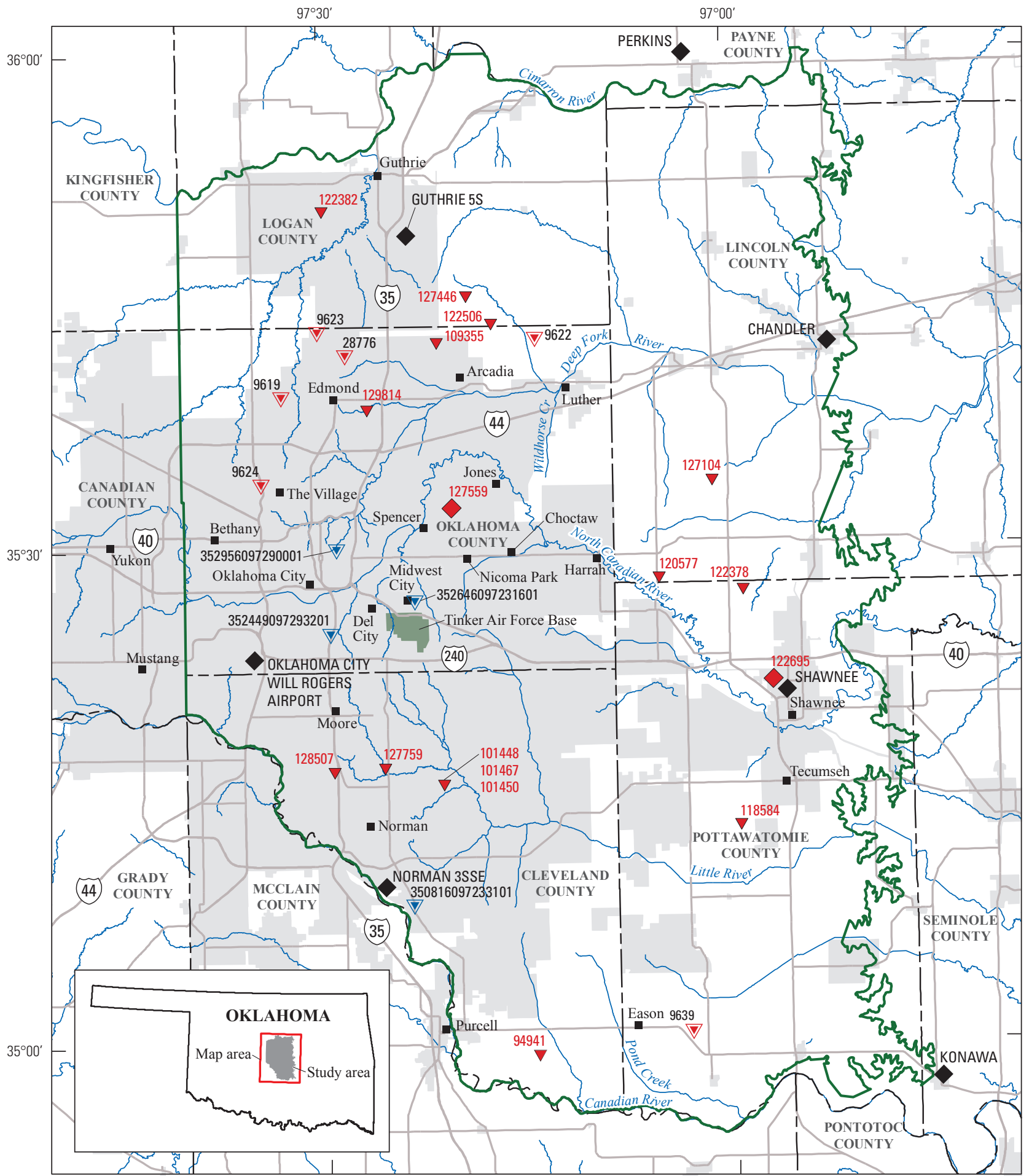

Base from Horizon Systems Corporation, 2010, University of Oklahoma Center for Spatial Analysis, 2013, and U.S. Census Bureau, 2001 Universal Transverse Mercator projection, Zone 14 North American Datum of 1983

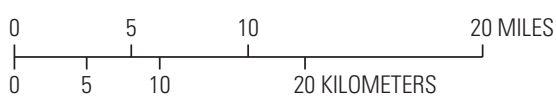

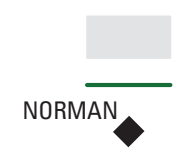

94941
Central Oklahoma aquifer from Runkle, Christenson, and Rea, 1997

EXPLANATION
Cities and incorporated places

Extent of Central Oklahoma aquifer (study area)

Cooperative observer station (precipitation, snowfall, and temperature) and identifier 35081609723310

Continuous recorder well with Oklahoma Water Resources Board (OWRB) identifier

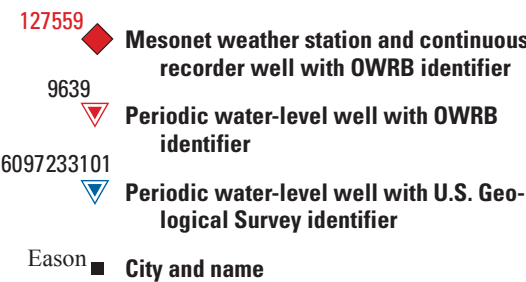

Figure 1. Central Oklahoma aquifer location, counties, cities, continuous-recorder wells, periodic water-level wells, cooperative observer stations, and Mesonet weather stations. 
water per acre of land per year (Oklahoma Water Resource Board, 2010). The U.S. Geological Survey, in cooperation with the Oklahoma Water Resources Board, investigated the hydrogeology and simulated groundwater flow in the aquifer using a numerical groundwater-flow model. The U.S. Geological Survey provides unbiased, timely, and relevant information, studies, and data about groundwater resources of the Nation.

\section{Purpose and Scope}

The purpose of this report is to describe an investigation of the Central Oklahoma aquifer that included analyses of the hydrogeology, hydrogeologic framework of the aquifer, and construction of a numerical groundwater-flow model. The groundwater-flow model was used to simulate groundwater levels and to analyze water-budget for 1987 to 2009 and for various pumping scenarios during a 50 -year predictive simulation (2010-2059). This report provides information to the OWRB that can be used to determine the maximum annual yield of groundwater from the Central Oklahoma aquifer based on proposed management plans. The scope of the hydrologic investigation is the Central Oklahoma aquifer, which encompasses the freshwater zone in the Garber Sandstone and Wellington Formation, including the underlying Chase, Council Grove, and Admire Groups, and the overlying alluvium and terrace deposits. The study area for this investigation was the extent of the Central Oklahoma aquifer (fig. 1).

\section{Physiography}

The Central Oklahoma aquifer underlies all or parts of Cleveland, Logan, Lincoln, Oklahoma, Payne, and Pottawatomie Counties (fig. 1). The eastern part of the study area is characterized by low hills, with topographic relief ranging from 30 to 200 feet. The western part of the study area consists of gently rolling grass-covered plains, with topographic relief of less than 100 feet. The highest altitude of the Central Oklahoma aquifer area is approximately 1,300 feet above the North American Vertical Datum of 1988 (NAVD 88) in the western part of the study area and the lowest altitude is approximately 800 feet above NAVD 88 in the northeastern part of the study area along the Cimarron and Deep Fork Rivers (fig. 1) (Parkhurst and others, 1996).

\section{Climate}

The Central Oklahoma aquifer is in an area having a continental subhumid climate. The average monthly temperature in Oklahoma County, which includes much of the study area, is approximately 60 degrees Fahrenheit, with a slight increase from the northern part of the county towards the south. The average maximum temperature typically is recorded in July at 93 degrees Fahrenheit and the average minimum temperature typically is recorded in January at 26 degrees Fahrenheit (Oklahoma Climatological Survey, 2011a).

Precipitation data were obtained from the Oklahoma Climatological Survey's Web site for seven cooperative observer (COOP) stations distributed across the extent of the Central Oklahoma aquifer (fig. 1); (Oklahoma Climatological Survey, 2011b). Cooperative observer stations compose a climateobservation network for the National Weather Service at which volunteers record observations in a variety of land-use settings (National Weather Service, 2011). Daily maximum and minimum temperatures, snowfall, and 24-hour precipitation data are collected at these stations. The seven stations used for the investigation described in this report were Chandler, Guthrie 5S, Konawa, Norman 3SSE, Oklahoma City Will Rogers Airport, Perkins, and Shawnee (fig. 1). Precipitation data were downloaded for the entire period of record, which varied for each station. Years with less than 10 months of data in the period of record for a station were omitted from the analysis and trace amounts of precipitation were not included. Climate data from the seven COOP stations spanned from 1893 at the Guthrie 5S station to 2009 at 7 stations. Precipitation data were not collected at some stations throughout the entire period of record (table 1).

Average annual precipitation in the study area from 1893 to 2009 was 34.27 inches (fig. 2). The 30-year average annual precipitation from 1980 to 2009 in the study area was 37.95 inches. Rainfall trends for the period of record indicate (1) below-average precipitation from approximately 1900 to 1940 , (2) variable precipitation from 1950 to the mid 1980 s, and (3) an above-average precipitation from the $1980 \mathrm{~s}$ until 2009.

Maximum monthly precipitation from 1980 to 2009 was 5.18 inches in May, minimum monthly precipitation was 1.33 inches in January, and the monthly average precipitation was 3.18 inches (fig. 3). The period from 1950 to 1979 had below-average precipitation spanning two substantial drought periods, with the average monthly precipitation of 2.78 inches, maximum average precipitation in May of 5.60 inches, and a minimum average precipitation in January of 1.08 inches (fig. 3). The difference in precipitation between the 1980-2009 period and the previous 30-year period (1950-1979) is primarily related to increased precipitation during the months of March, June, October, November, and December during the 1980-2009 period. Precipitation data (fig. 2) indicate that the 1980 to 2009 period was markedly wetter compared to the previous period (1893-1979), and the investigation described in this report was based on hydrologic data collected during this wetter period. 
Table 1. Data collection time periods of precipitation at the cooperative observer (COOP) stations used in the Central Oklahoma aquifer study area.

\begin{tabular}{clcccc}
\hline $\begin{array}{c}\text { Station } \\
\text { number }\end{array}$ & \multicolumn{1}{c}{ Station name (fig. 1) } & Period of record & Number of years & 1950-1979 average & 1980-2009 average \\
\hline 1684 & Chandler & $1902-2009$ & 99 & 32.60 & 35.82 \\
3821 & Guthrie 5S & $1893-2009$ & 110 & 31.09 & 36.27 \\
4915 & Konawa & $1943-2009$ & 101 & 33.27 & 31.05 \\
6386 & Norman 3SSE & $1895-2009$ & 106 & 33.19 \\
6661 & Oklahoma City Will Rogers Airport & $1898-2009$ & 78 & 102 & 35.45 \\
7003 & Perkins & $1928-2009$ & $1902-2009$ & Average & 36.13 \\
8110 & Shawnee & & $\mathbf{3 3 . 2 8}$ \\
\hline
\end{tabular}

${ }^{1}$ Not continuous.

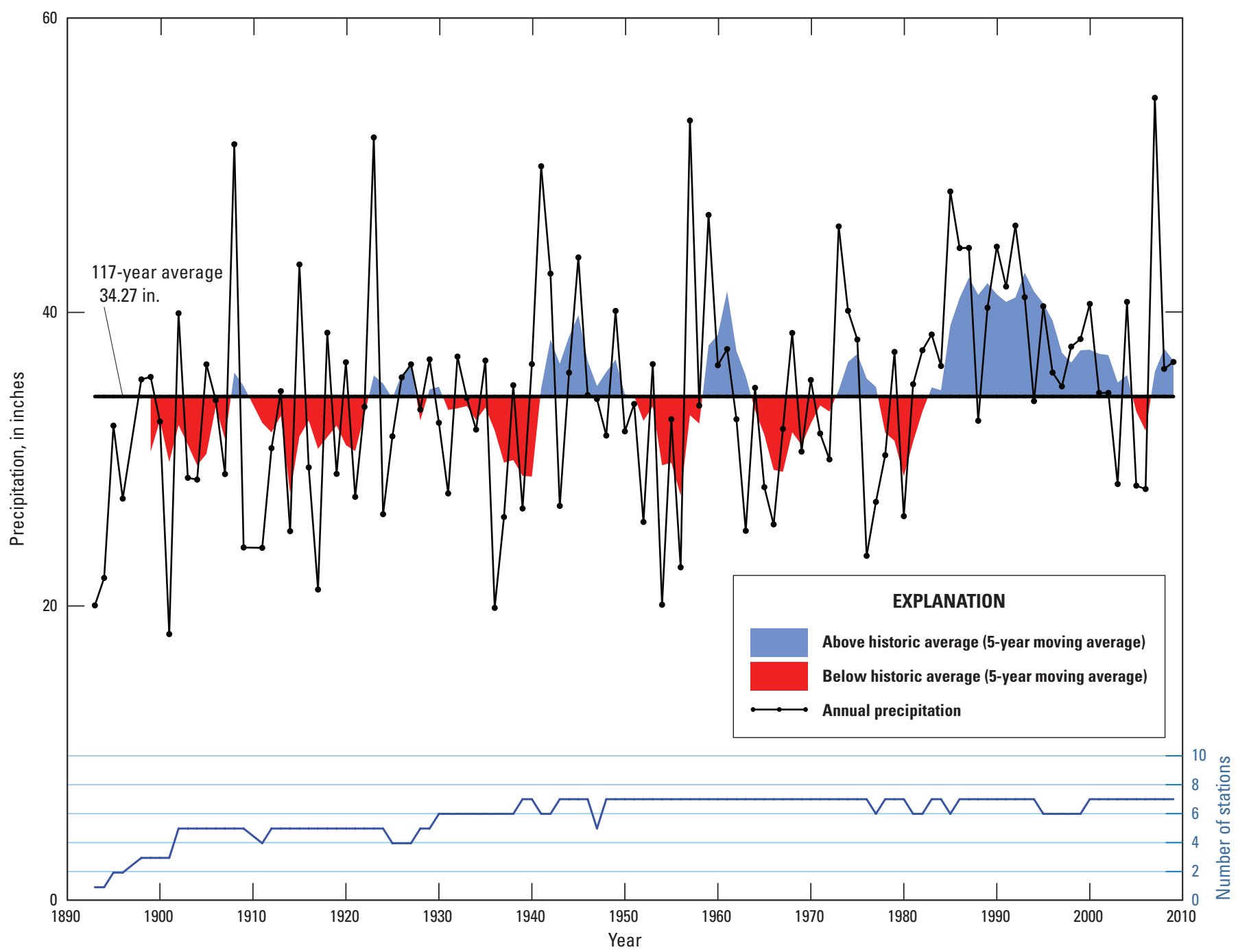

Figure 2. Annual precipitation 1893-2009, 5-year moving average, and the number of cooperative observer stations recording during each year in the Central Oklahoma aquifer study area. 


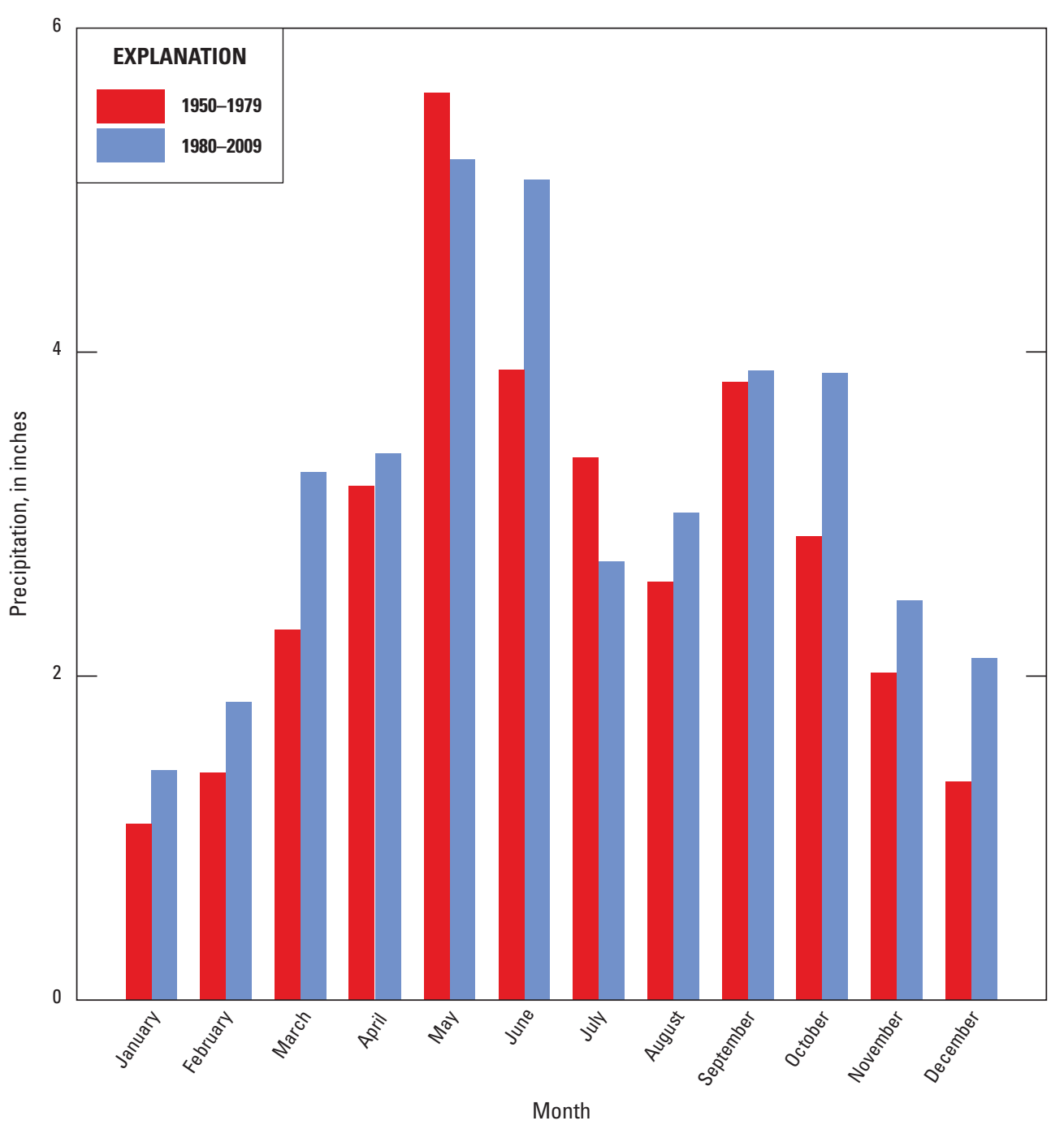

Figure 3. Average monthly precipitation during the time periods 1950-1979 and 1980-2009 for cooperative observer stations in the Central Oklahoma aquifer study area.

\section{Geology of the Central Oklahoma Aquifer}

The Central Oklahoma aquifer consists of Quaternary-age alluvium and terrace deposits and Permian-age geologic units (figs. 4 and 5 and table 2) (Christenson and others, 1990). Groundwater flows between these geologic units and both the Quaternary-age and Permian-age units are used as a source of groundwater. The investigation described in this report focuses primarily on the Permian-age units because water stored in the Quaternary-age alluvium and terrace is a small fraction of the water stored in the Permian-age units. The Central Oklahoma aquifer is referred to locally as the Garber-Wellington aquifer because the Central Oklahoma aquifer is dominantly composed of the Permian-age Garber Sandstone and Wellington Formation. However, this report does not use the name Garber-Wellington aquifer because the flow system includes Quaternary-age alluvium and terrace deposits and parts of the underlying Chase, Council Grove, and Admire Groups (table 2).

\section{Geologic History and Depositional Environments}

Understanding the geologic history is useful for determining the best approach for characterizing the hydrogeologic framework and hydraulic conductivity of the Central Oklahoma aquifer. Central Oklahoma was located near the equator during the early Permian age and shifted between wet and dry climates (Ziegler, 1990). The Permian-age geologic units that make up the Central Oklahoma aquifer were deposited on a shallow depositional slope by a system of fluvial, deltaic and marginal marine environments (Breit, 1998). However, Kenney (2005) states that the directional variability in paleocurrent indicators provide evidence that the Garber Sandstone was dominantly a fluvial system. Sea levels of the inland sea that covered much of the midcontinent were fluctuating during the Permian time (Siemers and others, 2000), which resulted in a range of depositional environments that are indicated in the various rock types of the area. The rock types and textures of the Chase, Council Grove, and Admire Groups, for example, indicate frequent fluctuations between shallow marine and fluvial systems and transition to a carbonate shelf to the north 


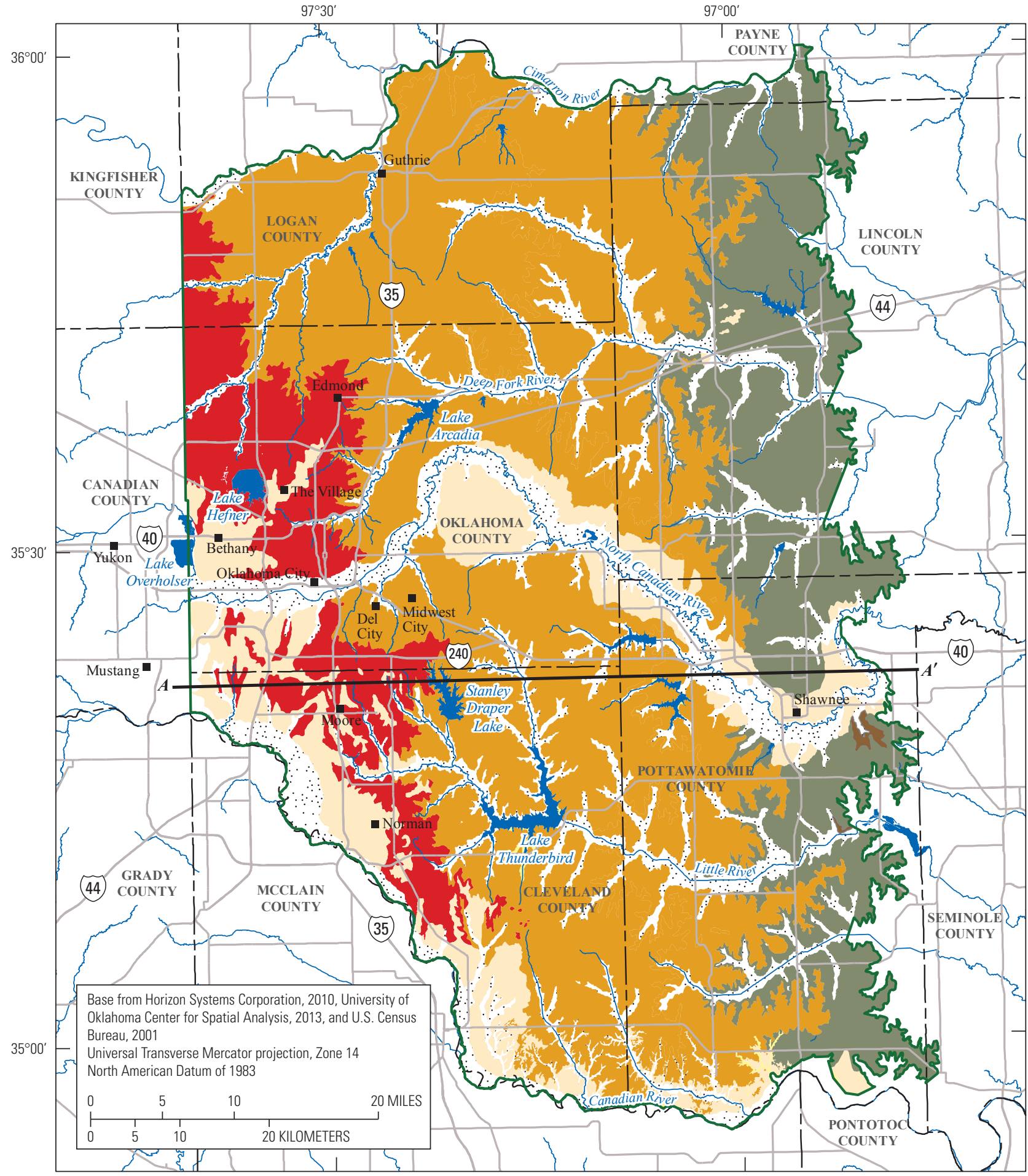

EXPLANATION

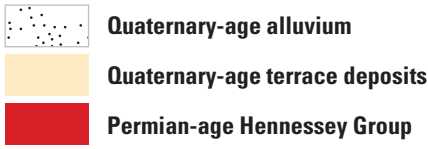

Permian-age Garber Sandstone and Wellington Formation (undifferentiated)

Permian-age Chase, Council Grove, and Admire Groups

Central Oklahoma aquifer from Runkle, Christenson, and Rea, 1997 Geology from Heran, Green, and Stoeser, 2003

Pennsylvanian Vanoss Formation

Figure 4. Surficial geologic units in the extent of the Central Oklahoma aquifer. 


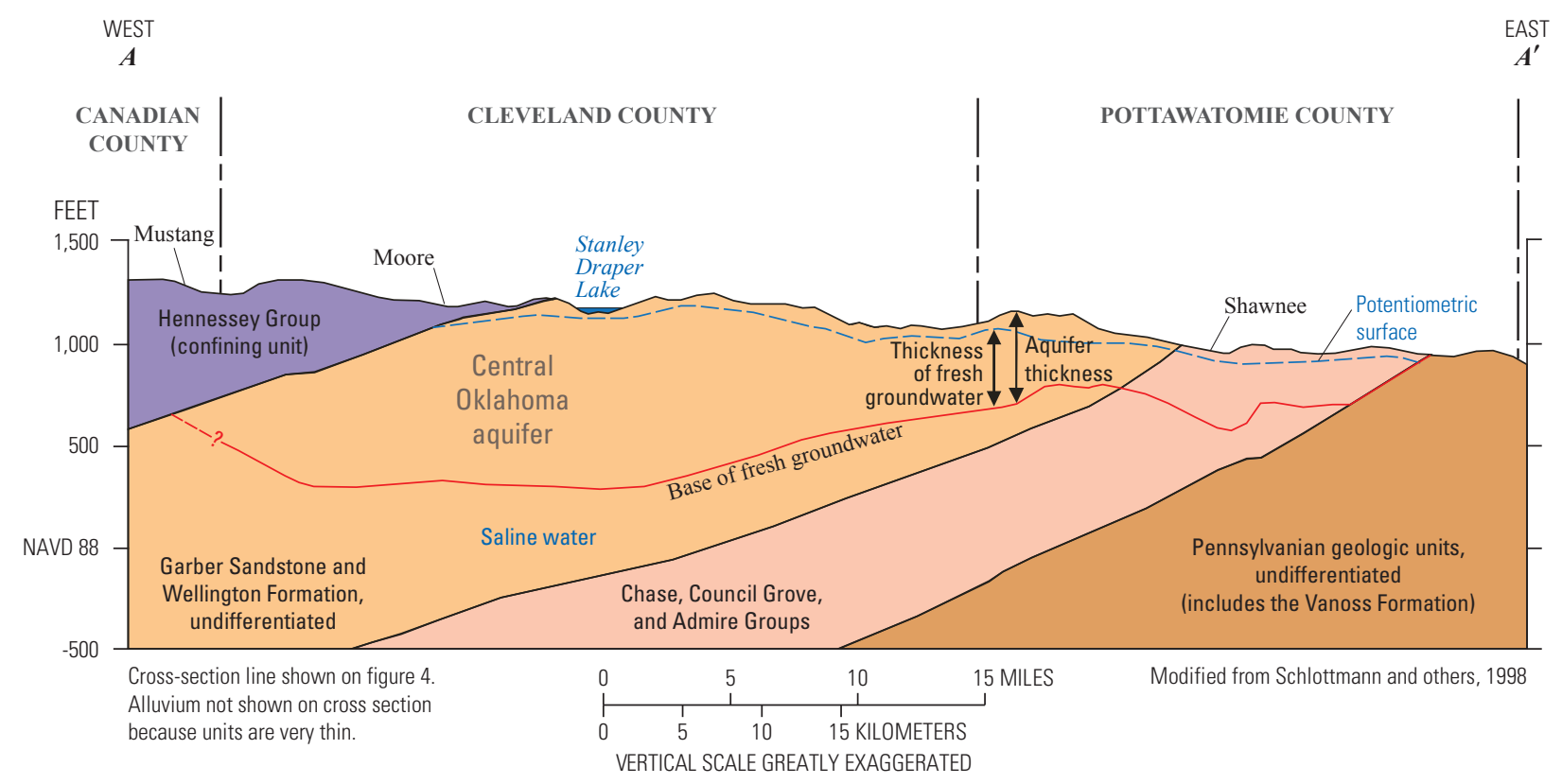

Figure 5. Cross-section $A-A^{\prime}$ diagram (shown on figure 4) showing bedrock geologic units of the Central Oklahoma aquifer.

Table 2. Stratigraphic column of geologic and hydrogeologic units in the Central Oklahoma aquifer. ${ }^{\text {a }}$

[Shaded grey hydrogeologic units and thickness are considered part of the Central Oklahoma aquifer]

\begin{tabular}{|c|c|c|c|c|}
\hline Erathem & System & Geologic unit & Aquifer unit type & Thickness, in feet \\
\hline \multirow{2}{*}{ Cenozoic } & \multirow{2}{*}{ Quaternary } & Alluvium & \multirow{2}{*}{ Aquifer } & ${ }^{\mathrm{b}} 0-100$ \\
\hline & & Terrace Deposits & & b0-100 \\
\hline \multirow{7}{*}{ Paleozoic } & \multirow{6}{*}{ Permian } & Hennessey Group & Confining & ${ }^{\mathrm{c}} 0-600$ \\
\hline & & Garber Sandstone & \multirow{2}{*}{ Aquifer } & \multirow{2}{*}{ b $1,165-1,600$} \\
\hline & & Wellington Formation & & \\
\hline & & Chase Group & \multirow{3}{*}{ Aquifer } & \multirow{3}{*}{ b570-940 } \\
\hline & & Council Grove Group & & \\
\hline & & Admire Group & & \\
\hline & Pennsylvanian & Vanoss Formation & Confining & d $250-490$ \\
\hline
\end{tabular}

${ }^{a}$ Modified from Parkhurst and others, 1989.

${ }^{\mathrm{b}}$ Christenson and others, 1992.

${ }^{c}$ Wood and Burton, 1968.

'Bingham and Moore, 1975. 
in Kansas (not shown on figures, outside of map extents). The rock types, textures, and strata of the Garber Sandstone and Wellington Formation indicate deposition of sand, silt, and clay eroded from the Ozark, Ouachita, and Arbuckle uplifts during a marine regression. The sediments were carried by a complex river system and delta flowing from east to west into the Anadarko Basin (Breit, 1998). The fine-grained texture of the Hennessey Group, a siltstone and shale, deposited on top of the Garber Sandstone, indicates a return of a shallow marine system during a minor sea-level rise or transgression.

A thin coating of hematite, an iron mineral, gives the formations in the area a reddish brown or purple color (Breit, 1998). Commonly referred to as red beds, there is a disagreement on the origin of the iron in the formations. Breit (1998) states that the history of reddening began during deposition, but continued into deep burial.

There is substantial local geologic variation in the Garber Sandstone and Wellington Formation caused by the meandering nature of fluvial and deltaic systems. The sandstone-tomudstone ratio in these units generally decreases downdip to the west, north of the Cimarron River, and south of the Canadian River (Gates and others, 1983).

\section{Quaternary-Age Alluvium and Terrace Deposits}

Alluvium and terrace deposits in the study area of Quaternary-age can be found along all major streams in the study area. These deposits are composed of lenticular beds of unconsolidated or loosely consolidated clays, silt, sand, and gravel with thicknesses ranging from 0 to 100 feet (ft) (Parkhurst and others, 1996). Terrace deposits along the North Canadian and Canadian Rivers are typically eolian in origin or are remnants of older alluvium and terrace deposits. These terrace deposits are topographically above the alluvium as a result of down cutting of the fluvial system with time. Although similar in composition, the alluvium is younger in age and is constantly being reworked by the modern river and eolian processes.

\section{Permian-Age Geologic Units}

Beneath or adjoining the alluvium and terrace deposits are consolidated bedrock units of Permian-age. The Permianage geologic units in the Central Oklahoma aquifer study area dip gently to the west at approximately 50 feet per mile (Bingham and Moore, 1975). There are no mapped or major structural features in the geologic units comprising the Central Oklahoma aquifer. The main structural feature in the area, the Oklahoma City anticline, is located in the subsurface below the Permian-age geologic units and has little effect on attitude or fracturing of the rock units of the Central Oklahoma aquifer (Carr and Marcher, 1977).

\section{Hennessey Group}

The Permian-age Hennessey Group overlies the western part of the Central Oklahoma aquifer and consists of interbedded red shale, clay, and some siltstone or fine-grained sandstone (Parkhurst and others, 1996). The Hennessey Group is composed of the Bison Formation, Salt Plains Formation, Kingman Formation, and the Fairmont Shale (Bingham and Moore, 1975). Although not considered to be part of the Central Oklahoma aquifer, the Hennessey Group outcrops in the western one-third of the aquifer area and acts as a confining layer because of its small transmissivity. Although transmissivity of this unit is small, there are small-yield wells completed in the Hennessey Group that provide enough groundwater for local domestic and stock use. Total thickness of the Hennessey Group ranges from 600 to 650 feet (Wood and Burton, 1968). However, in the study area the top parts of this group have been removed by erosion, resulting in thicknesses ranging from 0 to approximately 600 feet (Wood and Burton, 1968). A structure-contour map of the altitude of the base of Hennessey Group determined from correlation of geophysical logs was published in Christenson and others (1992), (fig. 6).

\section{Garber Sandstone and Wellington Formation}

In the study area, the Permian-age Garber Sandstone and Wellington Formation have similar lithologies and differentiating the two units in surface outcrops and in the subsurface by geophysical logs or core samples is difficult. Therefore, these two geologic units are treated as a single hydrogeologic unit in this report. The Garber Sandstone and Wellington Formation consist of cross-bedded, fine-grained sandstone with interbedded shale or mudstone (Bingham and Moore, 1975; Parkhurst and others, 1996; Breit, 1998). The sand grains in these two geologic units are generally rounded to sub-rounded quartz and are poorly cemented, mainly by hematite (Gates and others, 1983). Sand and clay lenses are common and make stratigraphic-unit correlation difficult in the study area. Generally, these two geologic units consist of about 75 percent sand in the central area of the aquifer decreasing to about 25 percent sand to the north and south (Wood and Burton, 1968). Fluvial and deltaic sedimentary structures, such as ripple marks, channel cuts, crevasse splays, and cross-bedding, are evident in the Garber Sandstone and Wellington Formation (Siemers and others, 2000), which implies that hydraulic properties are heterogeneous and specific hydrogeologic units are discontinuous. Where a full section is present, thickness of these units can range from 1,165-1,600 ft with a median thickness of 1,510 ft (Christenson and others, 1992). The Garber Sandstone and Wellington Formation are exposed at the surface in the central part of the study area but have been removed by erosion to the east. A structure-contour map of the base of the Wellington Formation, showing dipping to the west, determined from correlation of geophysical logs is shown figure 7. 


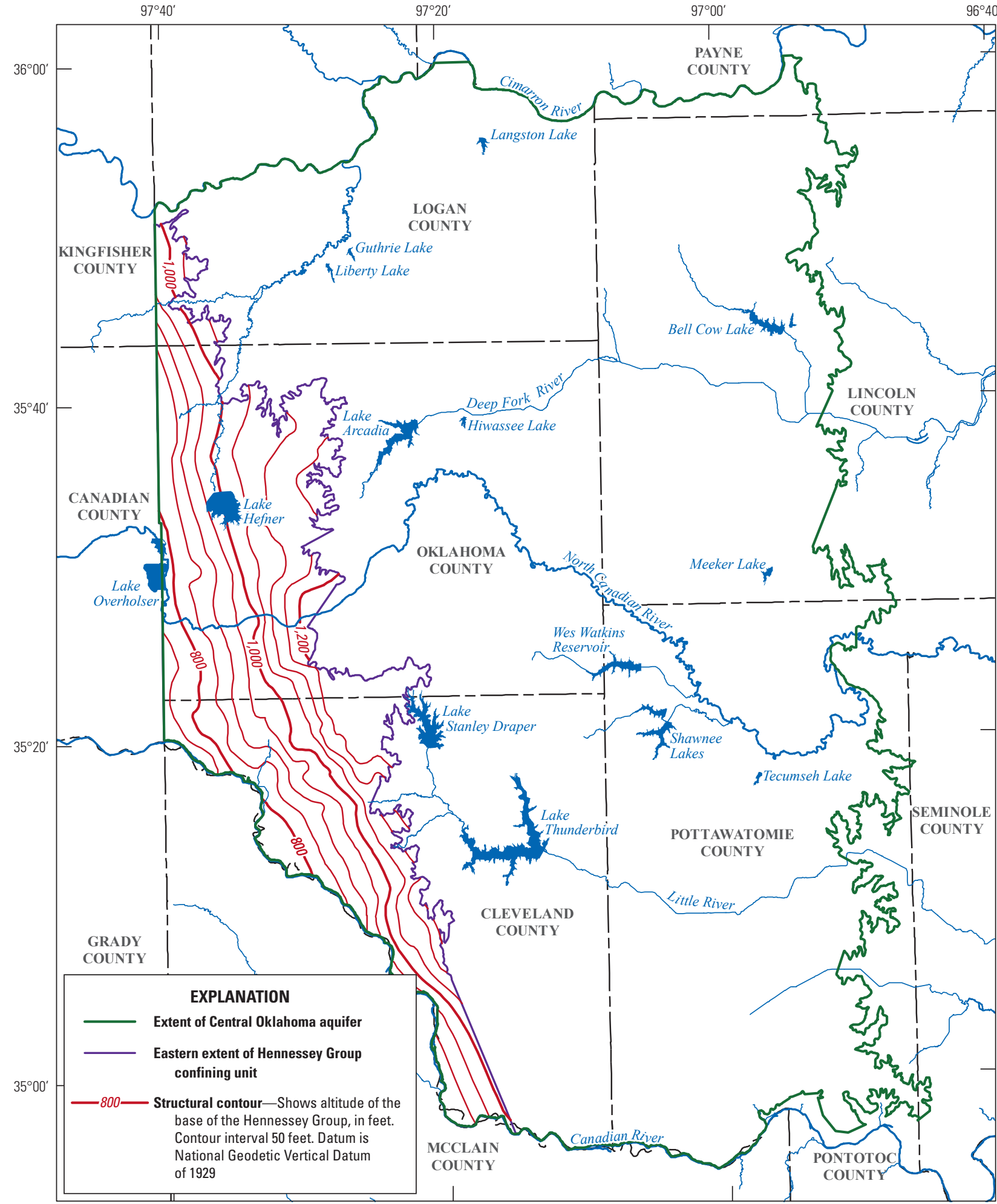

Base from Horizon Systems Corporation, 2010, and 0 , 4 , 8 University of Oklahoma Center for Spatial Analysis, 2013 Universal Transverse Mercator projection, Zone 14

North American Datum of 1983

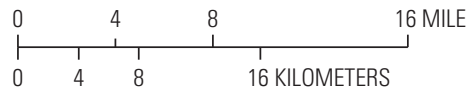

Central Oklahoma aquifer and Hennessey boundaries from Runkle, Christenson, and Rea, 1997 Structure contours modified from Christenson and others, 1992

Figure 6. Altitude of the base of the Hennessey Group (Hennessey confining unit). 


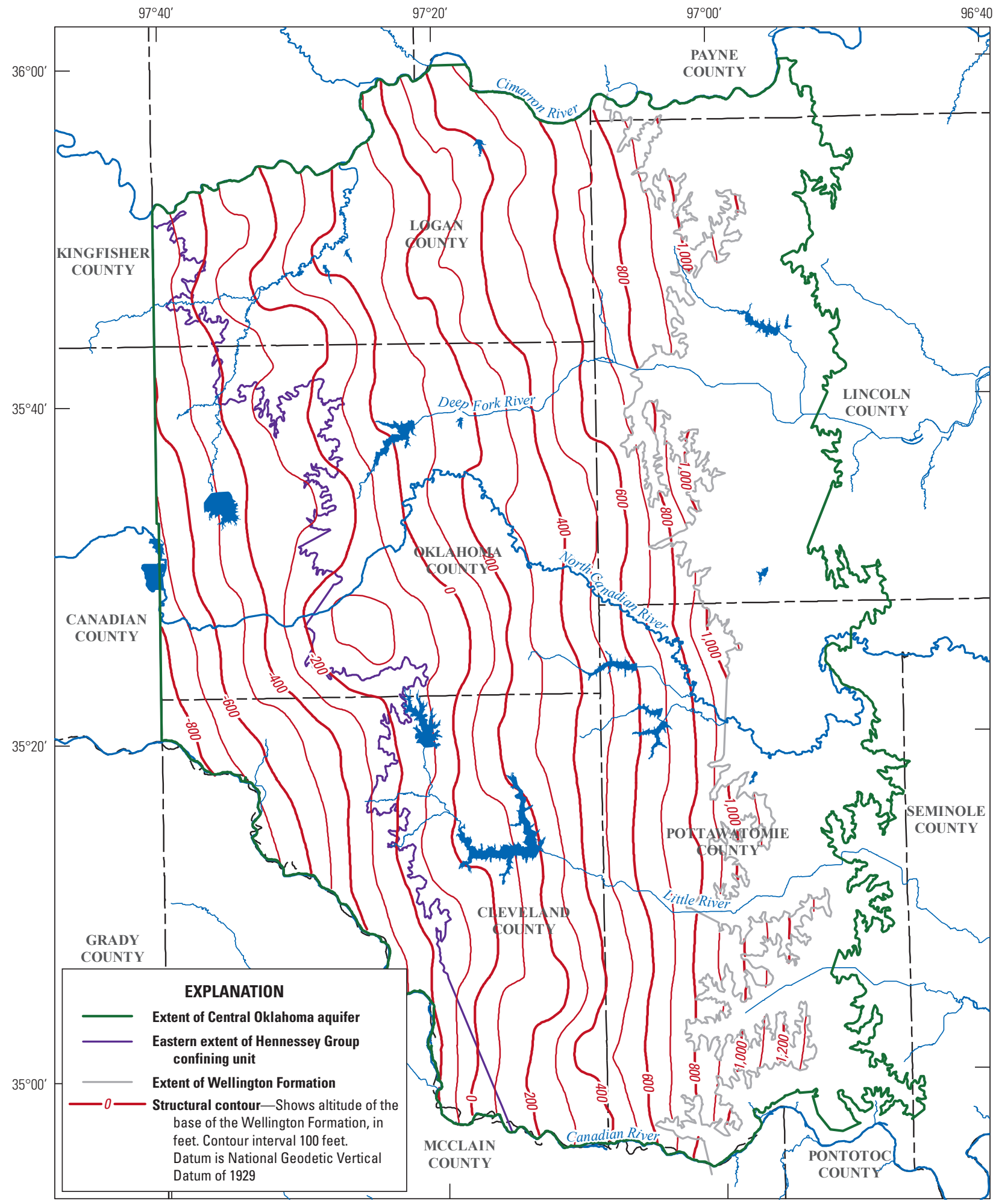

$\longrightarrow$

Base from Horizon Systems Corporation, 2010, and
University of Oklahoma Center for Spatial Analysis, 2013

Universal Transverse Mercator projection, Zone 14

North American Datum of 1983

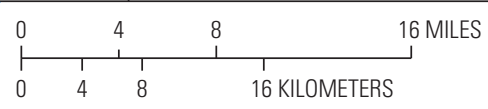

16 KILOMETERS
Central Oklahoma aquifer and Hennessey boundaries from Runkle, Christenson, and Rea, 1997 Structure contours modified from Christenson and

Figure 7. Altitude of the base of the Wellington Formation. 
Little published research has focused on the stratigraphy of the Garber Sandstone and Wellington Formation, except for several more recent Master's theses by Nkoghe-Nze (2002), Gromadzki (2004), Abbott (2005), and Kenney (2005). Those theses were funded by the Environmental Protection Agency to obtain a better understanding of the stratigraphy in the aquifer and how that stratigraphy might affect arsenic concentrations in production wells completed throughout the aquifer (Smith and others, 2009). The theses reported that the Garber Sandstone and Wellington Formation consisted of lithofacies characteristic of stacked channel bars, floodplain deposits, and related fluvial deposits. These lithofacies change abruptly and also grade gradually into one another vertically and horizontally, leading to considerable heterogeneity and discontinuity. The theses also state that the variable lithofacies, lack of continuous marker beds, and scarcity of fossils in the aquifer make traditional stratigraphic correlation difficult, especially over distances greater than 1 mile. Gromadski (2004) and Kenney (2005), using standard sieve analysis, reported that particle sizes in the Garber and Wellington sandstones sampled at the surface in the vicinity of Cleveland County were very-fine to fine-grained ( $0.125-0.25$ millimeters $)$ and moderately-well to well-sorted. The particle size and sorting in the sandstones was uniform across central Oklahoma.

Nkoghe-Nze (2002) studied the petrography of the Garber Sandstone and Wellington Formation. Nkoghe-Nze (2002) included analysis of petrographic thin sections from 5 core samples and 17 outcrop samples to describe the particle size, sorting, sandstone grain types, depositional matrix, and porefilling cement. In addition to collecting point-count data from new thin sections, the study used data and thin sections from Breit and others (1990), which reported porosity ranging from 17 to 30 percent from thin-section point counts in 7 cores from the Central Oklahoma aquifer. Nkoghe-Nze (2002) reported that the average porosity for outcrop samples was 14 percent and in core samples was 20 percent. Nkoghe-Nze (2002) also reported that the porosity in the sandstones was a primary, preserved porosity, defined as porosity developed as the sediment was deposited and includes inter- and intra-particle porosity (Tucker, 1981, p. 62). Average cement content was 20 percent in outcrop samples and 11 percent in core samples, indicating less cement is in the subsurface than in outcrops. Less percent cement in the subsurface than in outcrops indicates that cementation may not play a major role in the distribution of hydraulic conductivity in the subsurface. The compactional texture of the sandstones in thin sections and the absence of quartz cement (dolomite is the most common type of cement) indicate that the Garber Sandstone and Wellington Formation have never been deeply buried or heated to high temperatures.

\section{Chase, Council Grove, and Admire Groups}

Stratigraphically below the Wellington Formation are the Chase, Council Grove, and Admire Groups, which were considered to be undivided in the investigation described in this report. The Chase, Council Grove, and Admire Groups are composed of cross-bedded, fine-grained sandstone, shale, and thin limestone (Bingham and Moore, 1975). A structurecontour map of the base of Chase, Council Grove, and Admire Groups, showing a westward dip, determined from correlation of geophysical logs is shown in figure 8. Christenson and others (1992) state that where complete sections are present in wells, the combined thickness of these groups ranged from 570 to 940 feet with a median of 745 feet. Bingham and Moore (1975) referred to the Chase, Council Grove, and Admire Groups as the Oscar Group and assigned this Group to the Pennsylvanian-age system. Lindberg (1987) referred to these units as the Chase, Council Grove, and Admire Groups of Permian age. The term Oscar Group was not used in this study; terminology of Chase, Council Grove, and Admire Groups follows the usage of the USGS and is used in this report.

\section{Pennsylvanian-Age Geologic Units}

There are no Pennsylvanian-age geologic units in the Central Oklahoma aquifer, however the Vanoss Formation is described in this report because the Vanoss Formation is considered to be a hydrologic boundary of little to no flow.

\section{Vanoss Formation}

The Vanoss Formation is the oldest geologic formation in the study area. The Vanoss Formation underlies the Chase, Council Grove, and Admire Groups and outcrops locally along the eastern boundary of the study area (figs. 4 and 5). The Vanoss Formation consists of red-brown to grey shale and intermittent thin limestone and sandstone beds that range in total thickness from 250 to 490 feet (Bingham and Moore, 1975). This formation acts as a lower confining unit to the Central Oklahoma aquifer, limiting vertical groundwater movement.

\section{Characteristics of the Central Oklahoma Aquifer}

The geologic-unit description and information presented in this section provide the hydrogeology, hydrogeologic framework, and distribution of hydraulic properties used to form the numerical groundwater-flow model in the Central Oklahoma aquifer. In particular, model layers representing hydrogeologic units of similar hydrogeologic characteristics for the groundwater-flow model would be rather improbable to discern for the Central Oklahoma aquifer. Vertical and horizontal lithofacies change causes local heterogeneity and discontinuity of specific layers and the difficulty of stratigraphic-unit correlation indicated that hydraulic properties for the model would have to depend on data that generalized lithology and general grain size. 

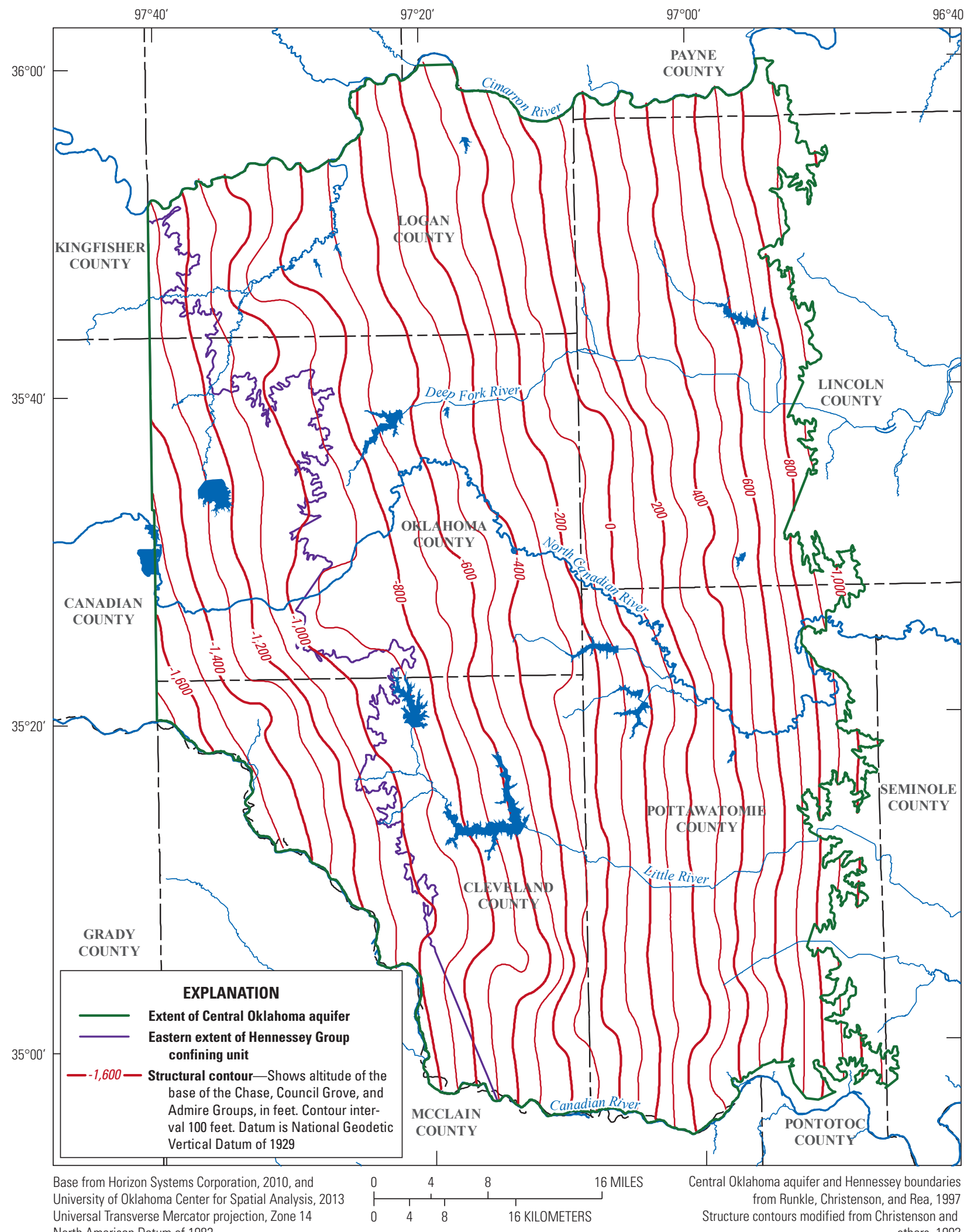

of 1983 jection, Zone 14

Structure contours modified from Christenson and

others, 1992

Figure 8. Altitude of the base of the combined Chase, Council Grove, and Admire Groups. 
The hydrogeology component of this investigation focused on groundwater flow through various lithologies in the aquifer, but also incorporated streamflows and recharge that are hydraulically connected and part of the groundwaterflow system. Potentiometric-surface data (synoptic water levels) were analyzed to describe regional groundwater flow and long-term (greater than 10 years) changes in groundwater levels. Groundwater-level fluctuations were analyzed to determine daily and seasonal trends with potential causes for those trends being attributed to variations in precipitation and barometric pressure, groundwater withdrawals, and changes in water use. Streamflow and base-flow data were summarized and recharge was estimated using methods applied at different scales.

\section{Regional Groundwater Flow}

An investigation by Parkhurst and others (1996) used a numerical groundwater-flow model combined with geochemical and petrographic data to describe the characteristics of the Central Oklahoma aquifer flow system. Results from their analysis indicated that groundwater in the shallow, local flow systems discharge to nearby streams and that the rate of flow and flux of water are greatest in these local flow systems, with transit times of tens to hundreds of years. Flow in the deeper part of the aquifer is slower and flowlines are longer than in the shallow, local flow systems. In this deeper flow system, groundwater flows under overlying small streams to discharge primarily to the Deep Fork and Little Rivers.

Transit times for groundwater flow in the Central Oklahoma aquifer can vary by several orders of magnitude. In the shallow flow systems, transit times may be tens to hundreds of years. In deeper flow systems that start along drainage basin divides, transit times are greater than 5,000 years (Parkhurst and others, 1994). Groundwater-flow in the Central Oklahoma aquifer is slowest in the confined part of the Garber Sandstone and Wellington Formation and in the less transmissive parts of the unconfined flow system, which includes part of the Chase, Council Grove, and Admire Groups. Groundwater in the confined part of the aquifer comes from recharge primarily from a small area of the unconfined part of the aquifer near $35^{\circ} 23^{\prime}$ latitude and $97^{\circ} 23^{\prime}$ longitude (near Tinker Air Force Base, location shown on figure 1) as seen in the mound of water on the potentiometric-surface maps (figs. 9 and 10).

The direction of horizontal regional groundwater flow can be inferred from potentiometric-surface maps of the Central Oklahoma aquifer. The elevation of the potentiometric surface is defined as the level to which water rises in tightly cased wells. An aquifer with substantial vertical flow can have multiple potentiometric surfaces. Potentiometric head in the Central Oklahoma aquifer changes with depth, so no single potentiometric surface could be mapped and no attempt was made to construct a potentiometric-surface map for the deep parts of the aquifer. Most of the deep wells completed in the aquifer are constructed with long gravel packs and multiple open intervals (screens, slots, or perforations) and are completed in more than one sandstone layer, each having a different hydraulic head (hereinafter referred to as head). The potentiometric surfaces described in this report approximate only the upper zone of saturation in the Central Oklahoma aquifer, sometimes referred to as the water table.

Water levels were measured in multiple wells across the Central Oklahoma aquifer in 1986-87 and 2009. The first measurement was done in 1986-87 as part of previous studies of the geochemistry and hydrogeology of the aquifer (Parkhurst and others, 1996; Christenson and others, 1992) and the second measurement was done in 2009 as part of this investigation. Wells measured for the 1986-87 and 2009 surveys were shallow (depth from land surface less than 300 feet), predominantly used for domestic supply, and were completed in the different geologic units in the Central Oklahoma aquifer, including the alluvial and terrace deposits. Many (169) of the wells measured in 2009 also were measured for the 1986-87 potentiometric-surface map.

\section{6-87 Potentiometric Surface}

A 1986-87 potentiometric-surface map was compiled in Christenson and others (1992) and Parkhurst and others (1996); (fig. 9). Water levels shown on that map were measured in more than 300 wells between December 22, 1986, and April 24, 1987. The 1986-87 water levels (depth to water, in feet below land surface) ranged from 1.5 to 177 with a median of 32 feet. The regional slope of the water table was west to east with considerable local variation. The $1986-87$ potentiometric-surface map shows "V" patterns that point upstream along the Deep Fork River, indicating the Deep Fork River was a drain for the groundwater-flow system, also known as a gaining stream. The potentiometric contours do not substantially show a "V" pattern in the vicinity of the North Canadian River, which indicates that there is little exchange of water between the aquifer and North Canadian River. The 1986-87 potentiometric-surface map shows that no streams on the aquifer are major sources of water to the groundwater-flow system, for example, few streams demonstrate the "V" pattern pointing downstream that would indicate that a stream was a major source of water to the groundwater-flow system, also known as a losing stream.

\section{Potentiometric Surface}

Water levels were measured in 280 wells as part of this investigation between February 17, 2009, and March 13, 2009. The 2009 potentiometric surface was published by Mashburn and Magers (2011). The 2009 water levels, in feet below land surface, ranged from 3.1 to 233.7 with a median of 35.8 feet (fig. 10). The potentiometric-surface altitude was calculated by subtracting depth to water from land-surface altitude. The land-surface altitude used for the 2009 potentiometricsurface map was determined by using a differentially corrected 


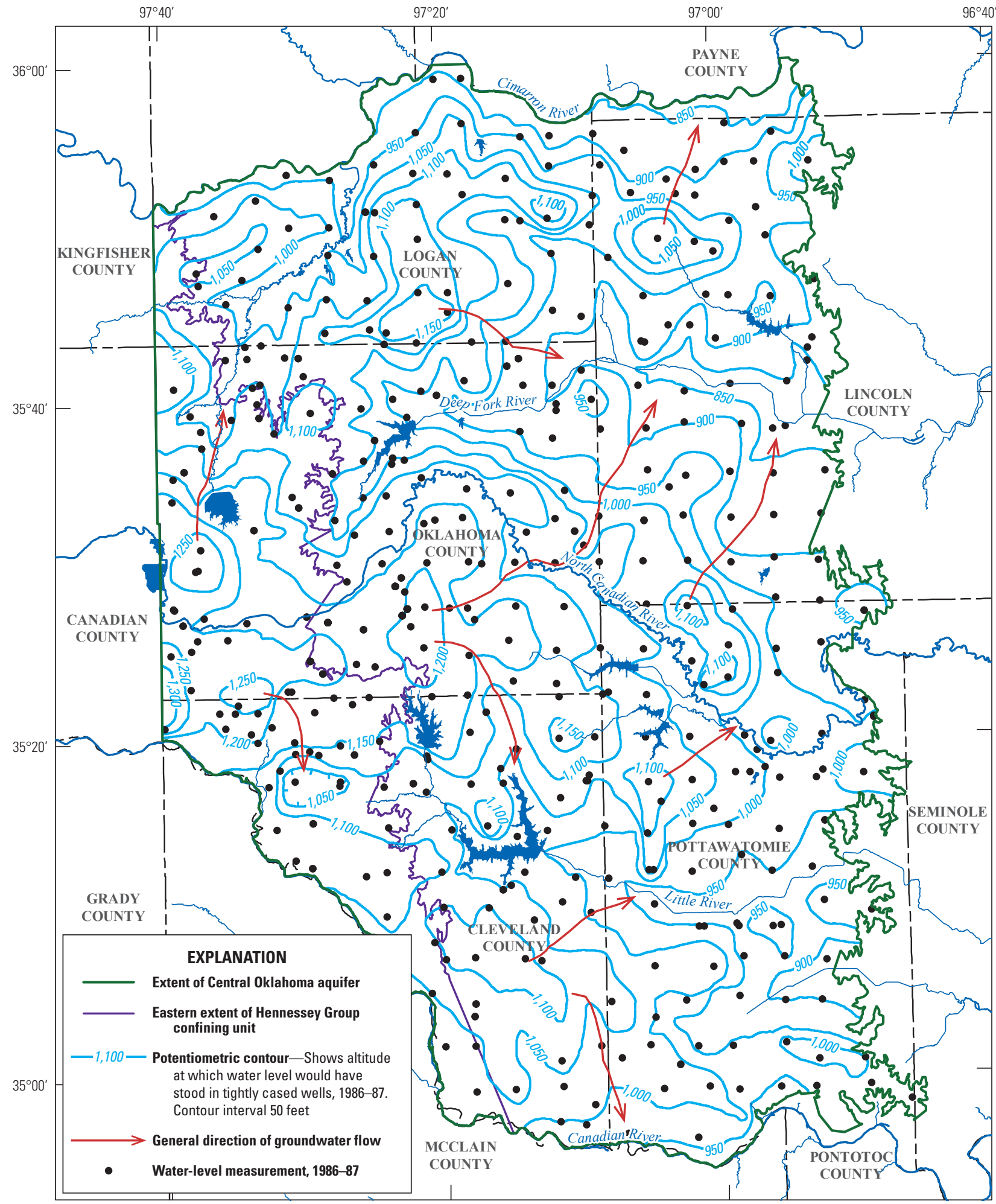

Base from Horizon Systems Corporation, 2010 , and University of Oklahoma Center for Spatial Analysis, 2013 Universal Transverse Mercator projection, Zone 14

North American Datum of 1983

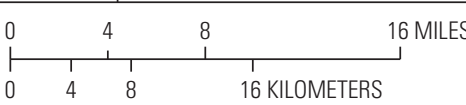

16 KILOMETERS

Central Oklahoma aquifer and Hennessey boundaries from Runkle, Christenson, and Rea, 1997 Potentiometric-surface contours and wells from Christenson and others, 1992

Figure 9. Potentiometric-surface contours (1986-87) and direction of groundwater flow in the Central Oklahoma aquifer. 


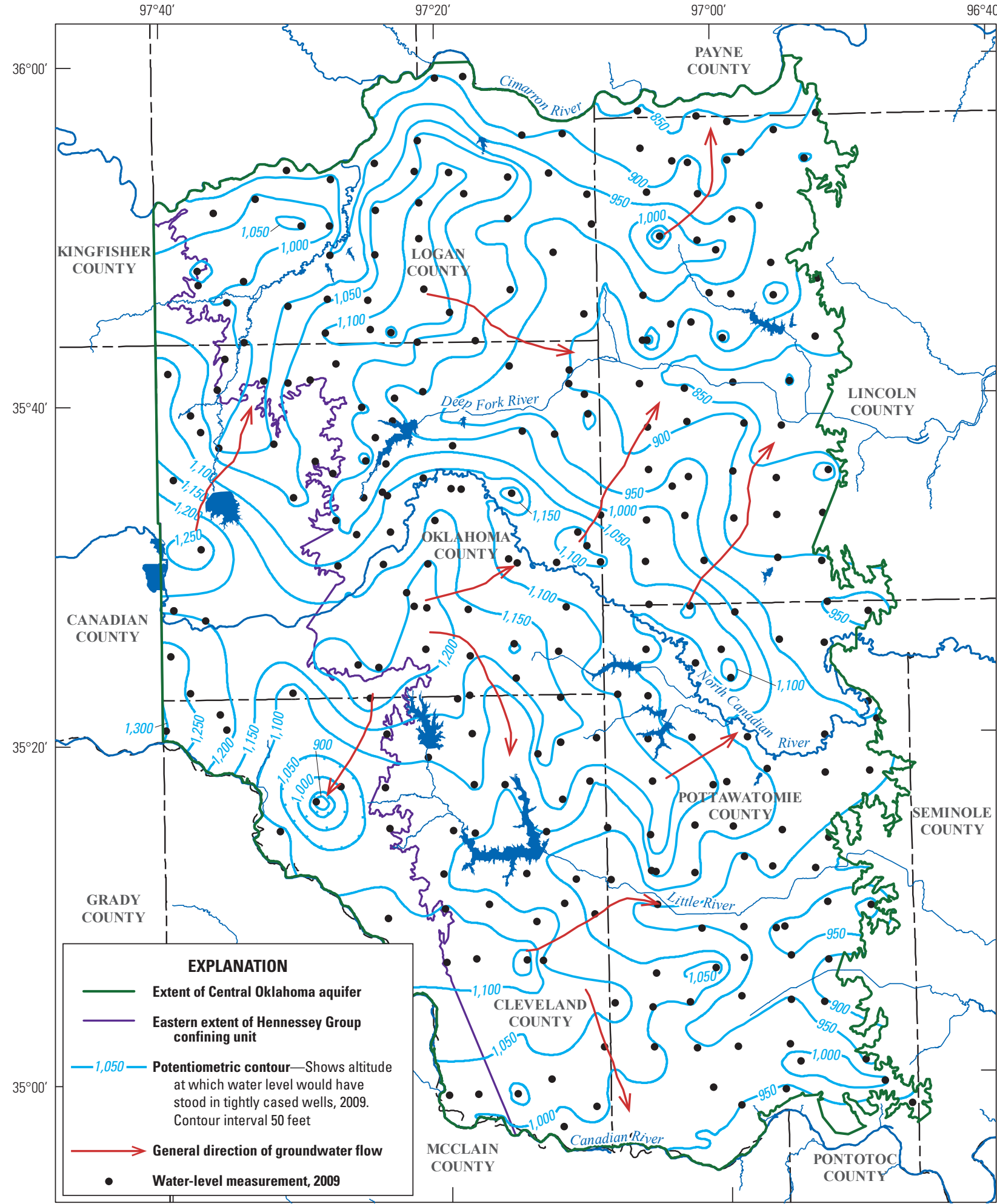

Base from Horizon Systems Corporation, 2010, and University of Oklahoma Center for Spatial Analysis, 2013 Universal Transverse Mercator projection, Zone 14

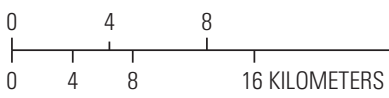

16 MILES

North American Datum of 1983

Central Oklahoma aquifer and Hennessey boundaries from Runkle, Christenson, and Rea, 1997 Potentiometric-surface contours and wells from Mashburn and Magers, 2011

Figure 10. Potentiometric-surface contours (2009) and direction of groundwater flow in the Central Oklahoma aquifer. 
Global Positioning System receiver with an accuracy of 0.5 foot and referenced to the North American Vertical Datum of 1988 (NAVD 88). Stream and lake elevations, which were obtained from a USGS 10-meter (32.8-foot) digital elevation model (DEM) (Gesch, 2007), were included when contouring the potentiometric surface, except for the western part of the aquifer that is confined by the overlying Hennessey Group where the Central Oklahoma aquifer is not considered to be hydraulically connected to the alluvial and terrace deposits above the Hennessey Group. The potentiometric-surface contours were generated in a geographic information system (GIS) by using stream and lake elevation data from the DEM and the potentiometric-surface altitudes determined at wells. The contours were adjusted manually based on professional judgment to address inconsistencies, especially near streams and lakes.

\section{Comparison of Water Levels from 1986-87 to 2009}

The water levels compared in this section of the report are only from those wells in which measurements were made in both the 1986-87 and 2009 time periods (169 wells). This comparison does not take into account the variability of water levels during the intervening years. Various factors also play roles in water-level changes and some factors may affect water levels on diurnal, seasonal, or annual timescales. These factors include tides, barometric-pressure changes, groundwater gains and losses from precipitation and streams, and groundwater losses to withdrawals. Similarities between the two maps include a regional slope from west to east, the Deep Fork River appearing to act as a drain to the groundwater-flow system, and the appearance of little or no exchange of water between the aquifer and the North Canadian River.

A (Wilcoxon) signed-rank test was used to determine if the 2009 water levels changed significantly from the 1986-87 water levels. A (Wilcoxon) signed-rank test is a nonparametric statistical hypothesis test used to compare two related samples or repeated measurements on a single sample to assess whether their population distributions differ. The null hypothesis for the (Wilcoxon) signed-rank test is that the average of the 2009 depth-to-water measurements is equal to the average of the 1986-87 depth-to-water measurements. The alternative hypothesis is that the average of the 2009 depth-to-water measurements is different than the average of the 1986-87 depthto-water measurements. Using a significance level of 0.025 for an upper-tailed test, the $z$ critical value is 1.96 . If the $z$ test statistic is greater than the $z$-critical value, then the null hypothesis is rejected in favor of the alternative hypothesis. The signed rank sum was 8,182 and resulting $z$-test statistic was 6.42 . The $z$-test statistic of 6.42 is greater than the $z$-critical value of 1.96. Therefore, the null hypothesis is rejected in favor of the alternative. This statistical test indicates that the 2009 depth-to-water measurements increased from the 1986-87 depth-to-water measurements, and this increase is statistically significant. The difference in the median depth-to-water measurements between the same wells for the two time periods was a decline of 3.75 feet. This decline in water levels was not consistent across the aquifer. There were some areas with declines in water levels and other areas in the aquifer where water levels increased. Water-level changes across an aquifer are caused by many factors and vary spatially. To determine an approximate amount of water this water-level decline indicates for the water from storage from the aquifer, the difference in median water levels can be multiplied by the porosity and area of the aquifer. A water-level decline of 3.75 feet multiplied by the area of the aquifer ( 3,000 square miles), multiplied by the minimum and maximum porosity expected for this aquifer (14 to 30 percent) resulted in a calculated change of water in storage from 1986 to 2009 ranging from 1,008,000 to $2,160,000$ acre-ft, assuming all water from storage came from unconfined conditions. This loss in storage from 1986-2009 period, when averaged per year, was approximately 44,000 to 94,000 acre-ft/yr. Some water from storage in parts of this aquifer may come from confined conditions. Water released from an aquifer under confined conditions may reduce the head, but the potentiometric surface can remain the same and the aquifer remains saturated. If the water released from the Central Oklahoma aquifer was under confined conditions, then this calculation (using changes in water levels) of water from storage under confined conditions would be greater than the storage calculated under unconfined conditions.

Several factors could have caused this decrease in water levels from 1986-87 to 2009 in the Central Oklahoma aquifer. A decrease in water levels indicates that more water is leaving the groundwater system than is entering the groundwater system. Less precipitation or an increase in the intensity of precipitation rates also could cause a reduction in recharge to the groundwater system. An increase in groundwater withdrawals could cause water levels and storage to decline. This decline in groundwater levels could reduce groundwater discharge to streams, especially those connected to the groundwater-flow system, such as the Deep Fork and Little River.

\section{Aquifer Saturated Thickness}

The 2009 potentiometric-surface contours (fig. 10) were subtracted from the base of freshwater contours (fig. 11) to construct a saturated-thickness map for the Central Oklahoma aquifer (fig. 12). The map of the base of fresh groundwater used in this study is the same map published in Christenson and others (1992) and Parkhurst and others (1996). Data points from Hart's (1966) base of fresh groundwater map also were included in the base of fresh groundwater map by Christenson and others (1992). Hart's (1966) base of freshwater maps was determined from geophysical logs and based on a dissolved solids concentration of 5,000 milligrams per liter $(\mathrm{mg} / \mathrm{L})$. For this study, the base of fresh groundwater was defined at $5,000 \mathrm{mg} / \mathrm{L}$ dissolved solids as described by Hart (1966), Christenson and others (1992), and Parkhurst and 


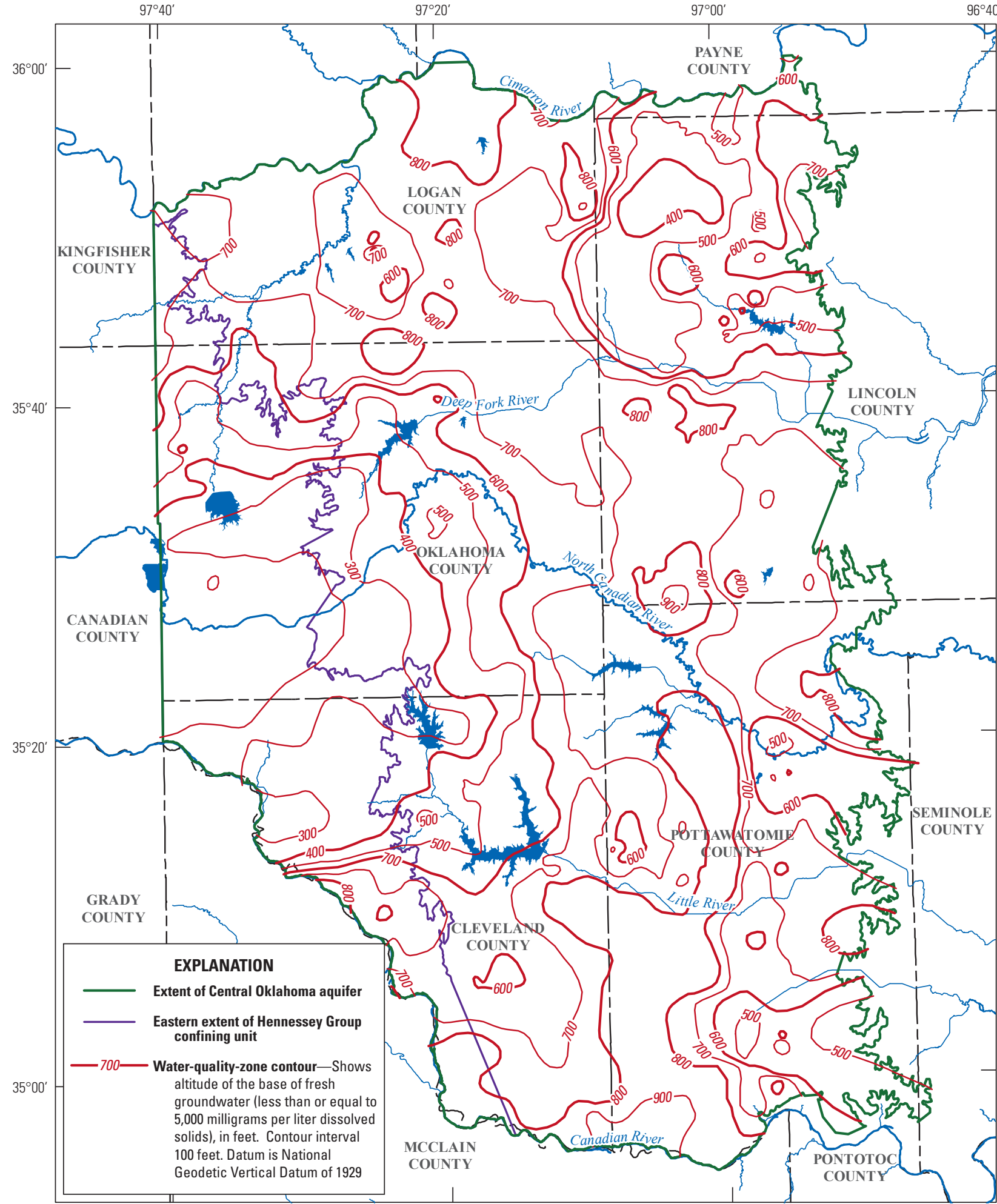

Base from Horizon Systems Corporation, 2010, and $\quad 0 \quad 4 \quad 16$ MLLS Central Oklahoma aquifer and Hennessey boundarie University of Oklahoma Center for Spatial Analysis, 2013 Universal Transverse Mercator projection, Zone 14 North American Datum of 1983

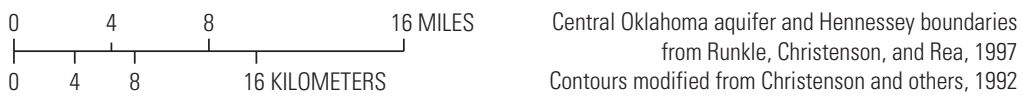

Figure 11. Altitude of the base of fresh groundwater [constructed by Christenson and others (1992) using geophysical logs]. 


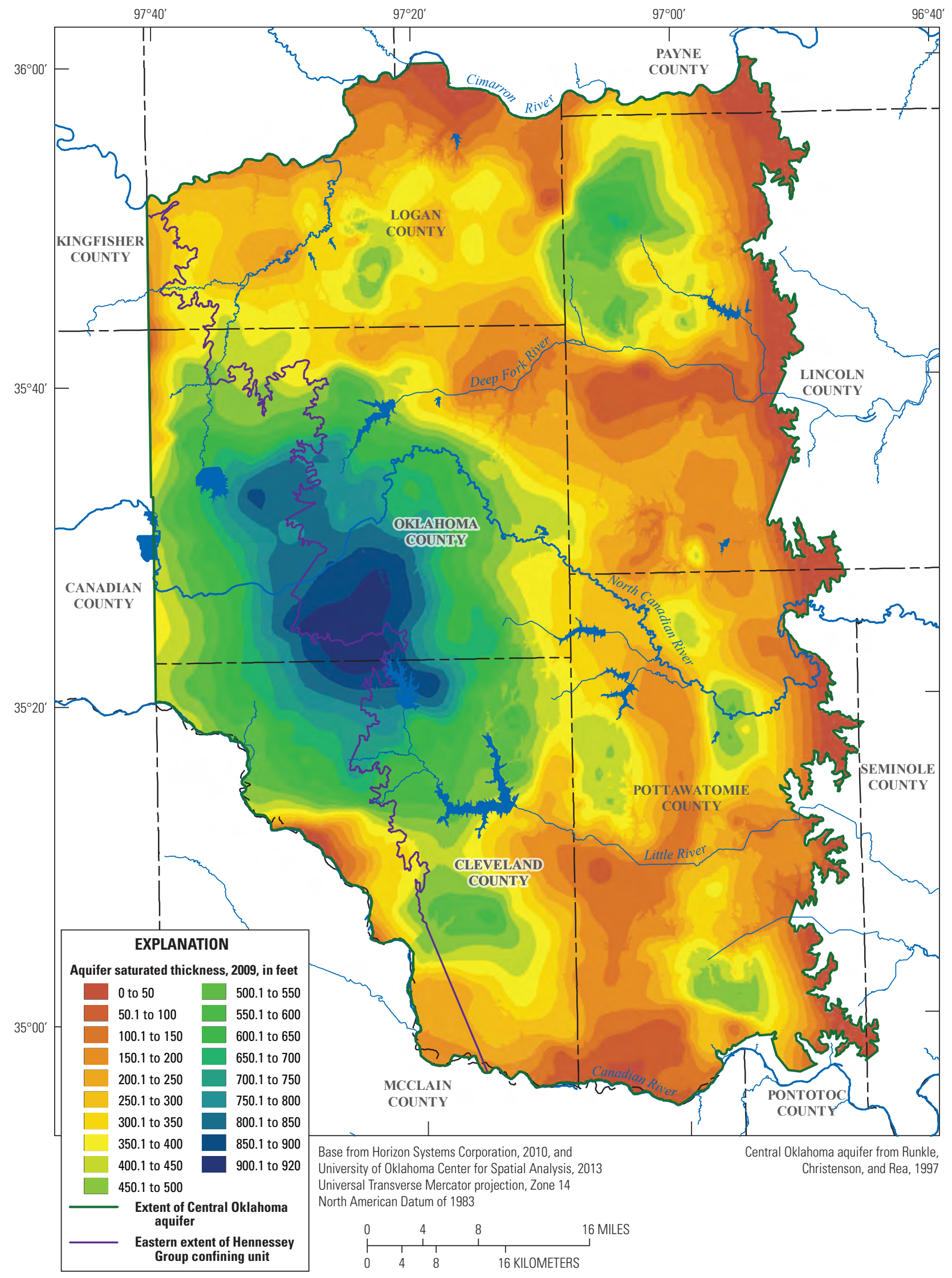

Figure 12. Saturated thickness (2009) in the Central Oklahoma aquifer. 
others (1996) (fig. 11). The OWRB regulates and permits only freshwater that has less than $5,000 \mathrm{mg} / \mathrm{L}$ dissolved solids.

The saturated thickness of the Central Oklahoma aquifer in the eastern part of the aquifer in Lincoln and Pottawatomie counties is relatively thin, 200-300 feet, related to the thinner geologic units in that area that are caused by the dip of the formations and erosion (fig. 12). The thickest zone of saturation is about 920 feet located near $35^{\circ} 25^{\prime}$ latitude and $97^{\circ} 25^{\prime}$ longitude (near Tinker Air Force Base, location shown on figure 1) along the extent of the Hennessey Group confining unit that allows freshwater recharge just to the east of the Hennessey Group extent and coincides with the deepest part of the base of freshwater (fig. 11) and the areas of higher percent sand in the aquifer (described in the Hydrogeologic Framework section of this report). The saturated thickness near $35^{\circ} 50^{\prime}$ latitude and $97^{\circ} 05^{\prime}$ longitude in another relatively thick part of the aquifer in northwest Lincoln County is about $650 \mathrm{ft}$.

\section{Water-Level Fluctuations}

Water-level observations can be used to characterize responses of aquifers to different stresses, providing insight into hydraulic properties of an aquifer. For example, relatively smaller storage capacity of porous media tends to produce more water-level fluctuations with higher amplitudes. Conversely, porous media with larger storage capacity produces water-level responses with lower amplitudes, assuming similar withdrawal rates. Water-level responses also may indicate annual trends, seasonal variations, and the relation of groundwater levels to surface-water discharge. Long-term water-level data can be used to monitor the effects of regional groundwater supply development and climate variability, changes in storage and recharge, and to calibrate groundwater-flow models. Responses to precipitation events - or lack thereofalso help to characterize an aquifer as confined or unconfined at different locations and depths.

Annual water-level measurements available through OWRB's Mass Measurement Program (Oklahoma Water Resources Board, 2013) and water-level data from the USGS National Water Information System (NWIS) database (U.S. Geological Survey, 2010b) were analyzed to determine the types of long-term (greater than 10 years) stresses in the aquifer (fig. 1). Continuous water-level recorders also were installed at 17 sites distributed across the aquifer extent during this aquifer study (2008-11) to characterize the geology, examine seasonal variability, and delineate potentially stressed areas of the aquifer. Water-level data from the USGS NWIS database also were retrieved to examine long-term pumping and precipitation trends (U.S. Geological Survey, 2010b).

One of the greatest water demands during the early use of the aquifer was from the Oklahoma City oil field, which reached a peak in production during the mid-1930s. Jacobsen and Reed (1949) noted that there was 35 feet of drawdown during this time and that as oil-field activities decreased during the 1940s, recovery of water levels was not observed.
Water-level declines in the Norman area were noted by the Bureau of Reclamation (1958), that described how water levels were stable from 1947 to mid-year 1951, followed by water levels declining by 21-24 feet in several wells from mid-year 1951 to 1953. Wood and Burton (1968) noted that substantial water-level declines were observed in five wells from 1942 to 1963 in the Norman-Midwest City area. The hydrographs of those wells showed seasonal water-level fluctuations caused by pumping of the aquifer. During summer months, water demand typically increases and more water is pumped from the aquifer. In one well east of Norman, water levels were speculated to have declined from withdrawals "required to meet public supply and military demands in the Norman area during World War II" (Wood and Burton, 1968).

Bureau of Reclamation (1958) states "available records from observation wells indicate that, since 1947, the static water level in the Midwest City-Tinker Air Force Base area (see fig. 1 for location) dropped about 50 feet, and in part of the Norman area the level has receded about 60 feet." The water-level change in the Midwest City-Del City-Tinker Air Force Base area likely was caused by an increase in water demand during World War II. Other areas of this aquifer also have experienced water-level declines, most notably, the Edmond and Nichols Hills (near The Village; fig. 1) areas (Carr and Marcher, 1977).

Wickersham (1979) also reported the seasonal production pattern in a city of Norman well observed from March 1977 through March 1978; during this time, water levels were the highest in June 1977, lowest in August 1977, and began to recover through March 1978. The wells that Wood and Burton (1968) monitored did not indicate any measurable response to precipitation. Additionally, the authors indicate that water levels in the shallow zones were affected by barometric pressure (Wood and Burton, 1968).

Water levels from 37 wells in the Central Oklahoma aquifer collected annually as part of the OWRB's Mass Measurement Program were examined for long-term trends. Only 18 wells had a period of record of approximately 10 years to determine long-term trends; 11 of the 18 wells are actively measured as part of the Mass Measurement Program and 8 wells have a period of record of more than 30 years. The hydrographs of some of these wells indicate a possible long-term precipitation-related pattern that could be related to a historical wet period in Oklahoma from the mid-1980s through the early 2000s. Hydrographs from several wells are shown in figure 13: OWRB identification numbers 9619 (total well depth (TD) = 134 feet), $9622(\mathrm{TD}=87$ feet $)$, and 9624 $(\mathrm{TD}=110$ feet). However, these wells do not have a period of record long enough to examine water-level trends before that wet period.

Well locations in areas of known regulated groundwater withdrawals were analyzed to determine how water-level trends were affected by localized pumping. Water-level data from several wells indicated possible effects from pumping (fig. 14). Examples include the following wells and data: OWRB well identification number 9623 ( $\mathrm{TD}=410$ feet) is a 
Figure 13. Water levels from Oklahoma Water Resources Board Mass Measurement Program wells showing possible long-term (greater than 10 years) precipitation response in the Central Oklahoma aquifer area (see figure 1 for locations and figs. 2 and 3 for long-term precipitation graphs).
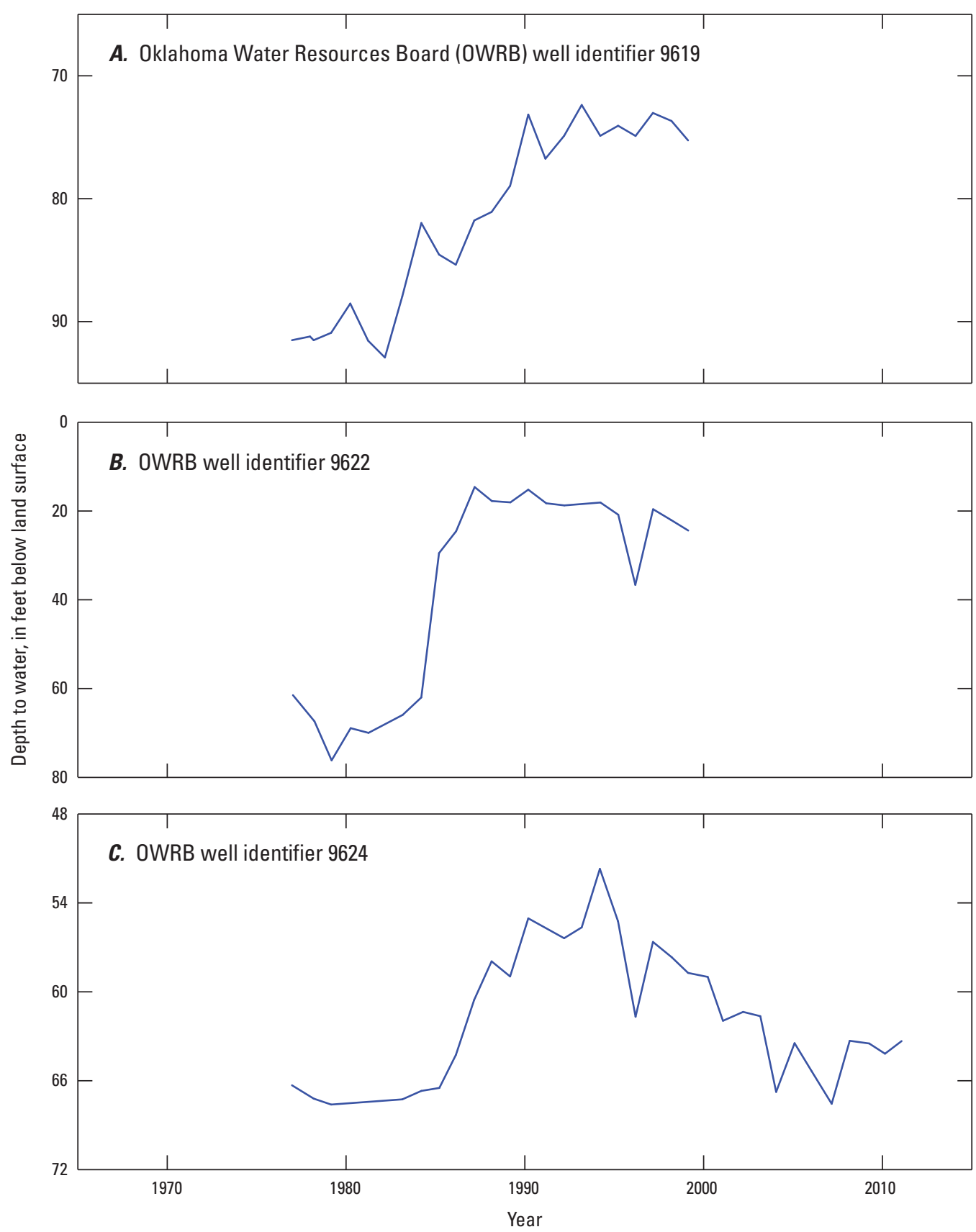

golf-course irrigation well and has a high water-level variability; OWRB well identification number $9639(\mathrm{TD}=148$ feet $)$ is a domestic well at which water levels declined throughout the 1980s and 90s; OWRB well identification number 28776 (TD $=122$ feet) is a domestic well at which water levels declined throughout the period of record that may be attributed to either domestic use, production from new city of Edmond water-supply wells beginning in 2006, or a major golf course about 1 mile away.

Long-term continuous and periodic water-level data from wells were acquired from the NWIS database (U.S. Geological
Survey, 2010b) and examined for pumping and precipitation trends; four examples are provided in figure 15 . The well with the longest-term data, from 1943 to 1989, was 350816097233101 (TD = 461 feet) with water levels in that well cycling between water-level decline and recovery, but had no general trend. The most noticeable stress shown by these hydrographs is the effect of groundwater pumping at well at sites $352646097231601(\mathrm{TD}=800$ feet) and 352956097290001 (TD = 791 feet), where cycles of depression and recovery are observed. The data from those two sites differ in that water levels in well 352646097231601 

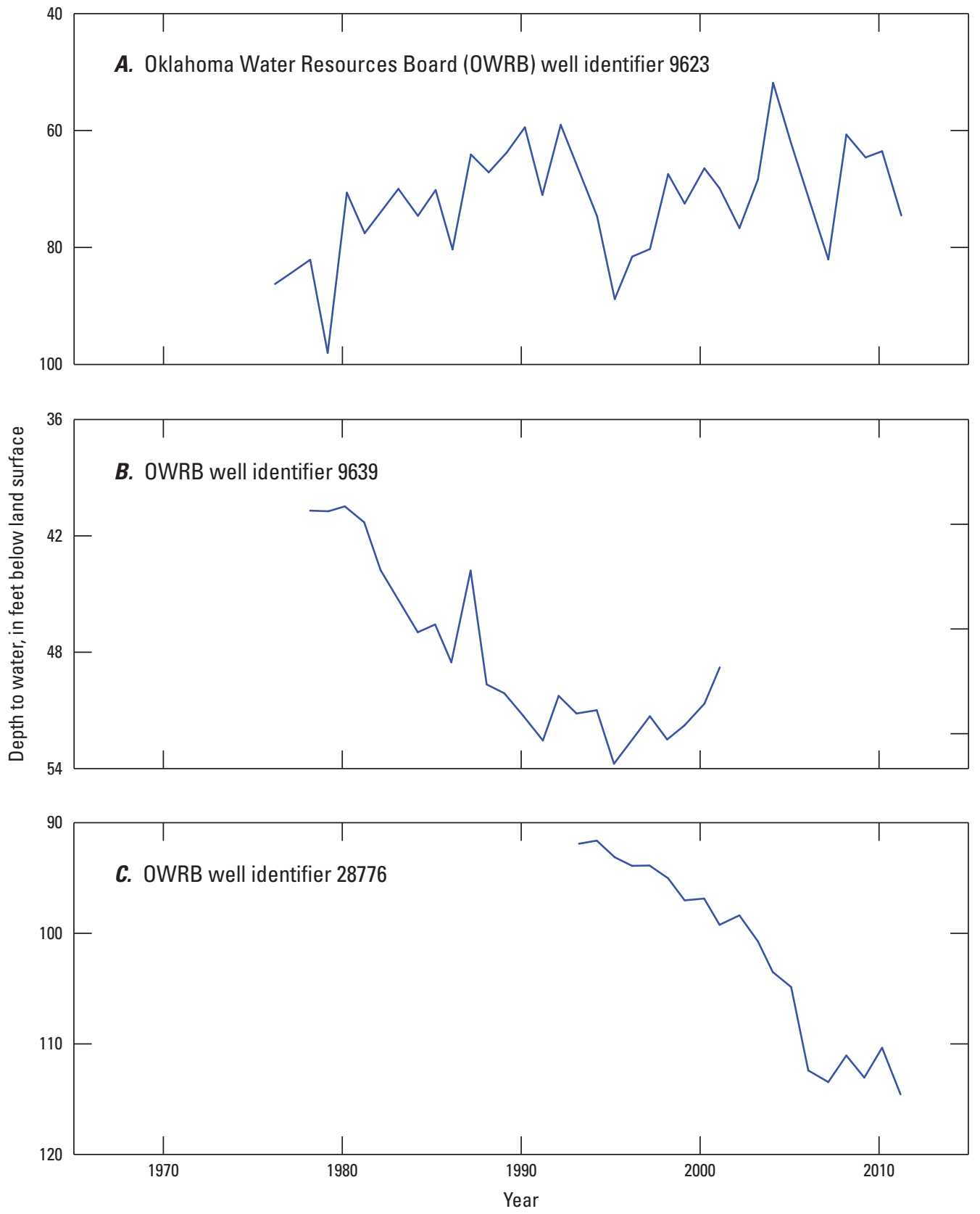

Figure 14. Water levels from Oklahoma Water Resources Board Mass Measurement Program wells showing possible response from localized groundwater pumping in the Central Oklahoma aquifer area (see figure 1 for locations and figs. 2 and 3 for long-term precipitation graphs). gradually declined approximately 75 feet between 1950 and 1957, whereas water levels in well 352956097290001 had no trend or a slight upward trend. Well 352646097231601 is near other production wells, indicating that the water-level decline in that well could be caused by long-term pumping. Well 352956097290001 is near a groundwater well permitted for irrigation purposes, which probably contributes to the cyclic decline and recovery in water levels measured at that well. Water levels in USGS well 352449097293201 changed around 1985 , perhaps caused by greater precipitation during that time.
There is no large-scale groundwater production within several miles of the site.

The OWRB installed continuous water-level recorders in 17 wells during the study, collecting data from 2008 to 2012, to identify various stresses affecting water levels (fig. 1). Stresses observed included precipitation events, long-term precipitation, localized pumping, large-scale pumping, and barometric pressure.

Water-level responses from precipitation events were observed in six OWRB continuous water-level recorder wells: OWRB identification numbers $118584(\mathrm{TD}=70 \mathrm{feet})$, 


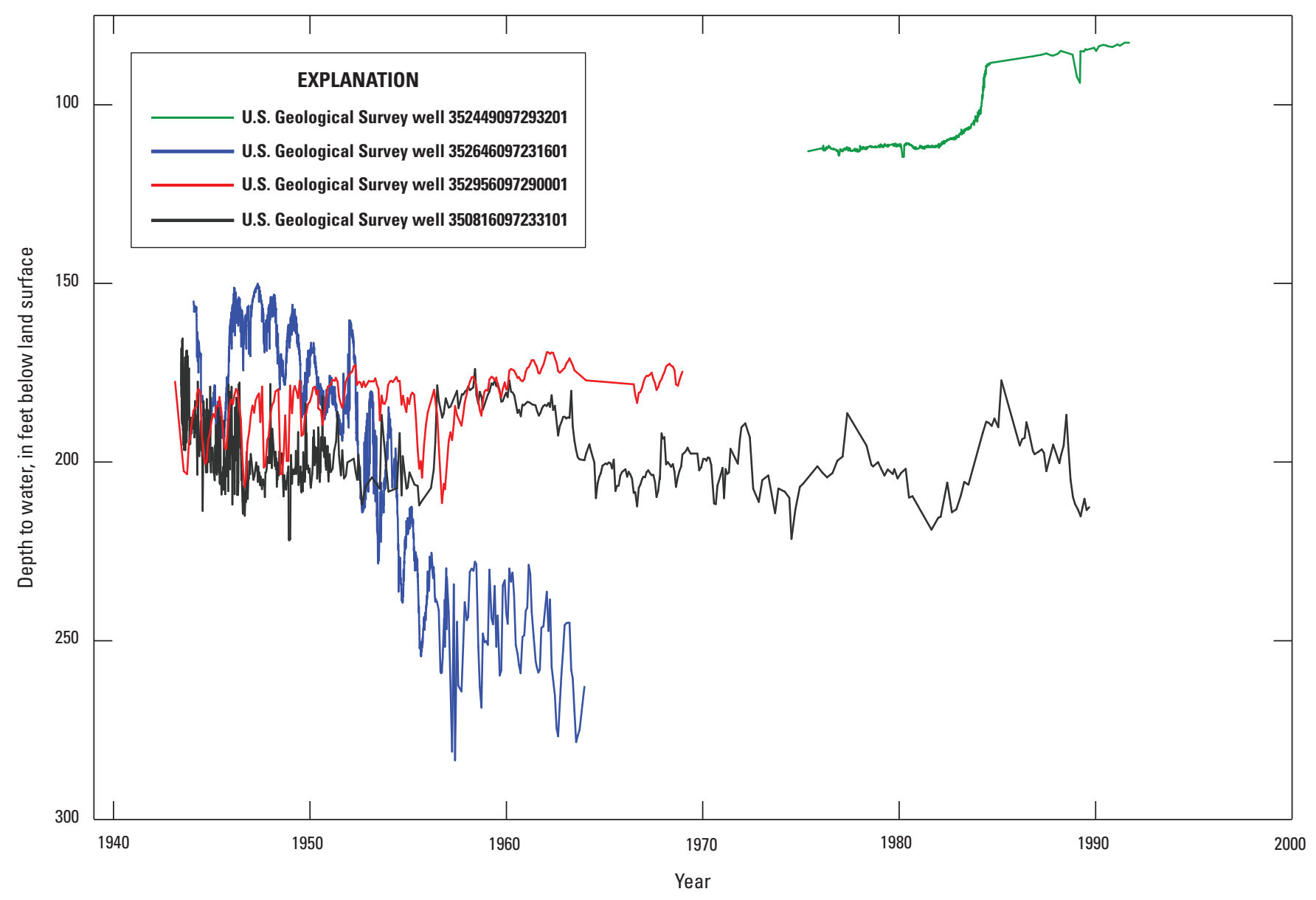

Figure 15. Water levels from USGS wells showing possible pumping and precipitation responses in the Central Oklahoma aquifer area (see figure 1 for locations and figs. 2 and 3 for long-term precipitation graphs).

$127446(\mathrm{TD}=183 \mathrm{feet}), 127559(\mathrm{TD}=140 \mathrm{feet})$, shown on figure 16 , and 120577 (TD = 50 feet $), 122378(\mathrm{TD}=80$ feet $)$, and 122695 (TD = 120 feet). Four of those wells were completed in the Chase, Council Grove, and Admire Groups that appeared to respond to precipitation events, possibly related to lesser cumulative sandstone thickness and small storage in those groups (see OWRB well 118584 in figure 16). Water levels in two wells completed in the Garber Sandstone responded to precipitation events: OWRB well 127446 responded to one precipitation event when more than 5 inches fell across the area, which was the largest precipitation event during the study; responses to precipitation in water levels in well OWRB 127559 were much smaller (fig. 16).

A multi-year precipitation pattern was observed in nine OWRB continuous water-level recorder wells. The general pattern observed over the course of the study was measurement of shallower water levels during 2010 and into 2011, with deeper water levels measured during the summer and fall of 2011 (fig. 16). Water levels that did not have multi-year precipitation patterns may not have had a long enough period of record or were affected by other stresses, such as large-scale groundwater production.
Effects of pumping were observed in three OWRB continuous water-level recorder wells as shown by several cycles of drawdown and recovery curves in figure 17 . One well (OWRB well 101448, TD = 460 feet) was about 50 feet from a production well with water-level drawdown and recovery curves of about 40 feet. The second well (OWRB well 109355, TD = 238 feet) was a 'plugged-back' oil field well and was possibly affected by a nearby (less than $1 / 4$ mile away) housing addition that was irrigating lawns, with drawdown and recovery curves of 2 to 3 feet. The third well (OWRB well 129814, TD = 740 feet) was an unused production well near other production wells, with water-level drawdown and recovery curves of 2 to 3 feet. Small-scale pumping effects were observed in three additional OWRB continuous water-level recorder wells and consisted of small pumping cyclic patterns (not shown on figures).

Barometric-pressure change can cause groundwater-level fluctuations on daily timescales (Butler and others, 2011; Rasmussen and Crawford, 1997; Spane, 2002; and Tanaka and Davis, 1963). Wood and Burton (1968) described waterlevel fluctuations caused by barometric-pressure changes in the Central Oklahoma aquifer. The premise of this effect is 


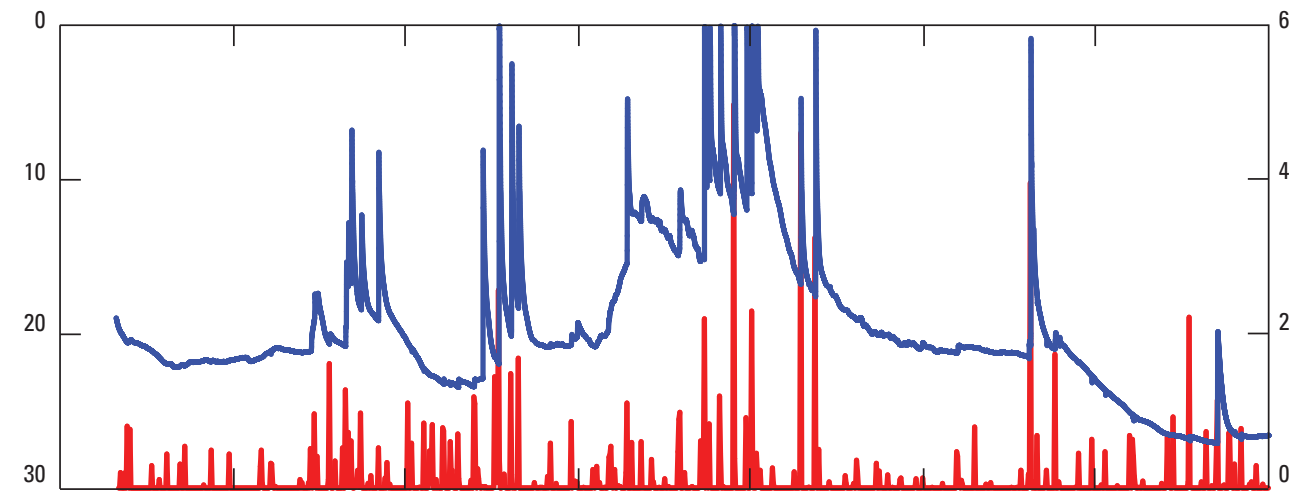

EXPLANATION

Oklahoma Water Resources Board (OWRB) well identifier 118584 water levelWell completed in Chase, Council Grove, and Admire Groups

Precipitation, Shawnee Mesonet Station
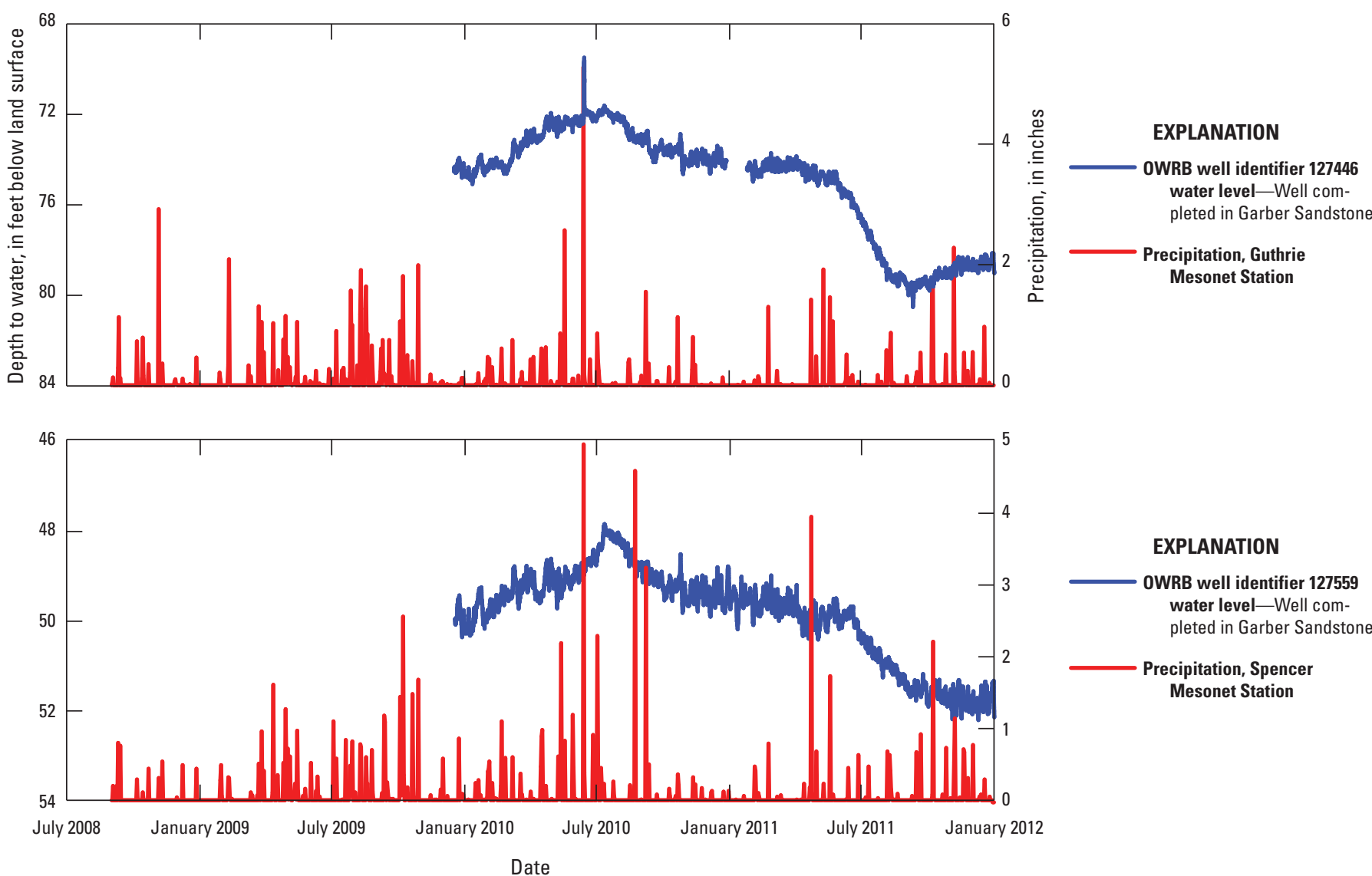

EXPLANATION

OWRB well identifier 127559 water level-Well completed in Garber Sandstone

Precipitation, Spencer Mesonet Station

Figure 16. Water levels from Oklahoma Water Resources Board continuous recorder wells showing possible long-term precipitation response in the Central Oklahoma aquifer area (see figure 1 for locations).

that when barometric pressures increase, groundwater levels are suppressed or decline; and when barometric pressures decrease, groundwater levels rise.

Data from the water-level recorders were graphed to examine the effect of barometric-pressure changes on water levels of the Central Oklahoma aquifer. This examination revealed that most of the shallow wells responded to barometric-pressure changes. Figure 18 is an example showing water levels at OWRB well 94941 (TD = 160 feet) and barometric pressure from the Norman Mesonet Station. At this site, increasing barometric pressure decreased water levels whereas decreasing pressure was associated with shallower water levels, with a time lag between the pressure change and the change in water levels.

Water levels in 9 of the 17 wells with continuous waterlevel measurements were affected by barometric-pressure changes, water levels in 3 wells were affected by large-scale groundwater pumping, water levels in 2 wells appear to have 

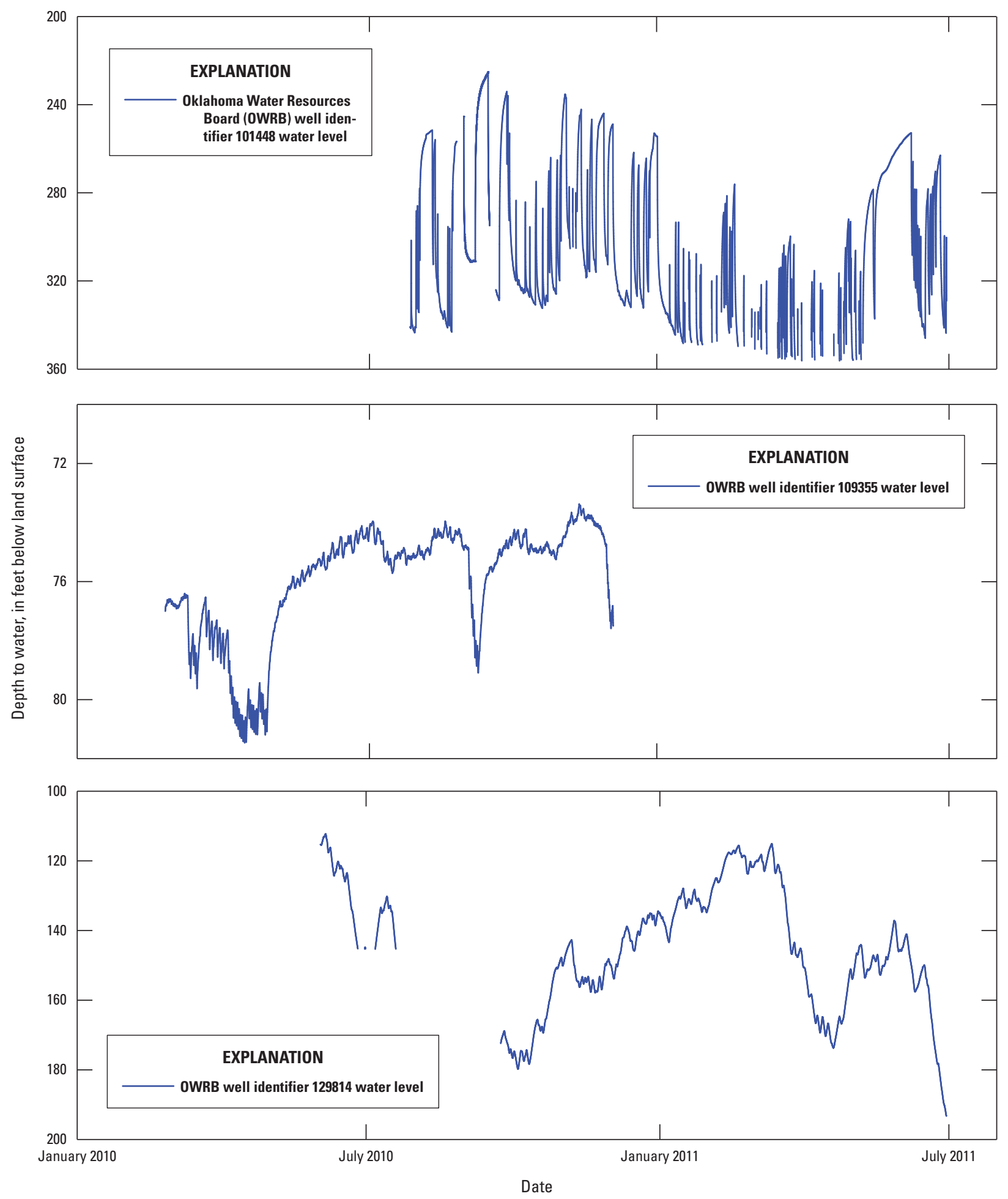

Figure 17. Water levels from Oklahoma Water Resources Board continuous recorder wells showing possible response from localized groundwater pumping in the Central Oklahoma aquifer area (see figure 1 for locations and figs. 2 and 3 for long-term precipitation graphs). 


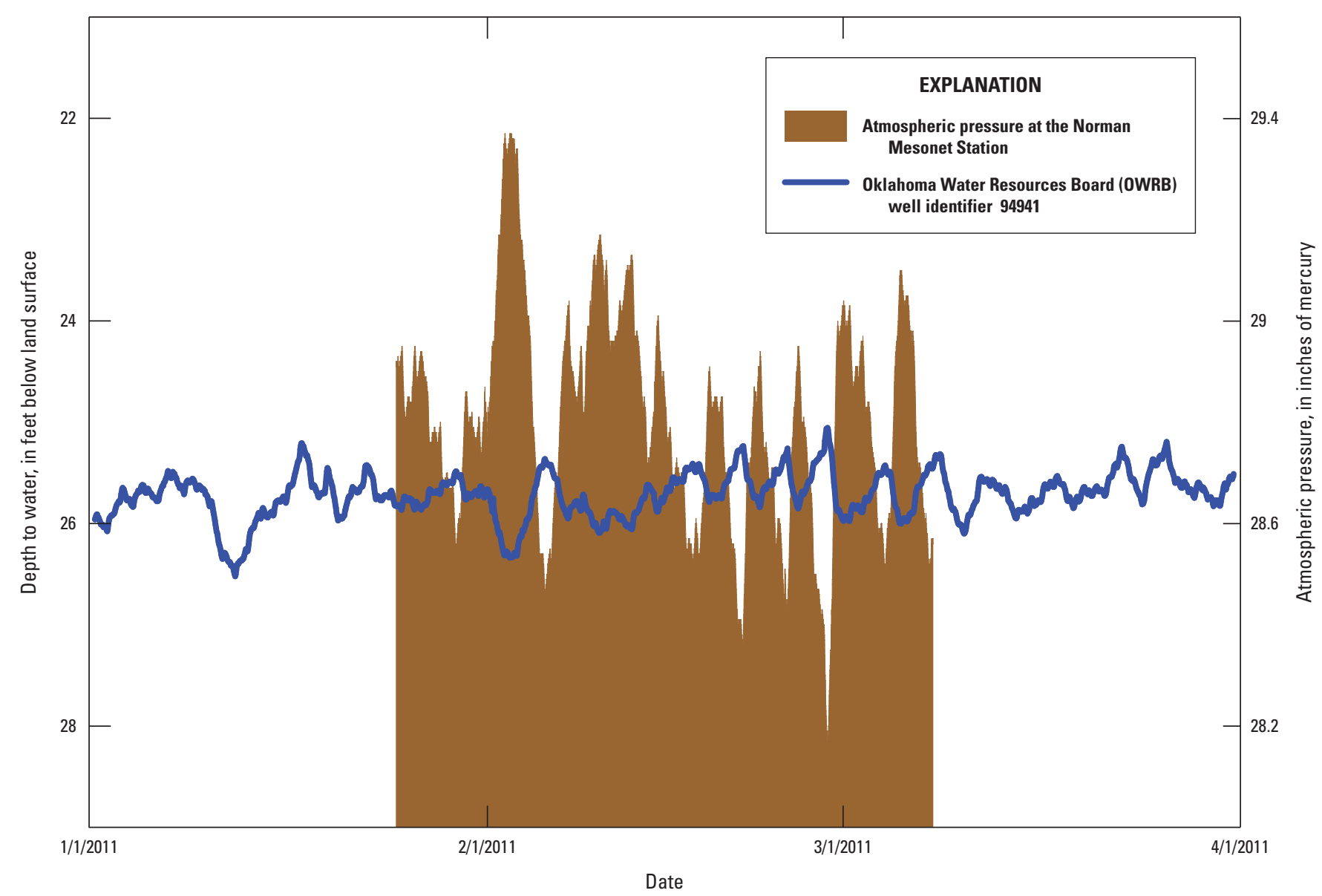

Figure 18. Water levels collected with a vented pressure transducer at Oklahoma Water Resources Board well site 94941 and atmospheric pressure measured at the Norman Mesonet Station in the Central Oklahoma aquifer.

been more affected by precipitation events than barometric changes, and water levels in 3 wells had periods of records for which local barometric-pressure data were not available.

The response of water levels in these wells measured for this investigation indicated that shallow wells were affected by barometric-pressure changes, precipitation, and pumping from nearby shallow wells. Water levels in deeper wells in the aquifer had minimal response to precipitation and barometricpressure changes, but respond to pumping from nearby deep wells. This response indicates there is low vertical hydraulic conductivity in this aquifer. The aquifer test, described in the Aquifer Hydraulic Properties section and appendix 1 in this report, indicated that water levels in shallow wells did not respond measurably to pumping from nearby deep wells during the time of the aquifer test.

\section{Withdrawals for Groundwater Use}

The Central Oklahoma aquifer provides water for publicwater supply, irrigation, commercial, industrial, recreation, fish, wildlife, and domestic uses. The OWRB regulates the use of water from the aquifer with the exception of domestic use, which can be defined as (1) water use of less than 5 acre-ft/yr for domestic (self-supplied) and agricultural purposes, or (2) water use for irrigation on land not exceeding 3 acres. A synopsis of the historical water use before the OWRB began keeping records is provided as background information about development of the aquifer. Regulated water-use data for the investigation described in this report were provided by the OWRB and domestic water use was estimated using census data. Water-use data for regulated and 
domestic categories were incorporated into the groundwaterflow model and were important for quantifying the amount of water discharging from the Central Oklahoma aquifer and for understanding the effects of water use on the aquifer water budget.

\section{Historical Groundwater Use}

Previous publications, such as Jacobsen and Reed (1949), Wood and Burton (1968), Mogg and others (1960), Benham Engineering Company, Inc. and Black \& Veatch (1967), Bureau of Reclamation (1958), C.H. Guernsey and Co. (1959), and Gould (1905), provide an estimate of groundwater development and use from the Central Oklahoma aquifer before 1967, when the OWRB began keeping records on water use. This historical information can be important to decisionmakers trying to manage this aquifer into the future. Use of groundwater from the Central Oklahoma aquifer began in the late 1800s during the settlement of the Oklahoma Territory (Edmond Historical Society, oral commun., 2009). Early mass transportation was achieved by passenger trains running from Kansas and Texas into central Oklahoma (Edmond Historical Society, oral commun., 2009). Steam engines used during that era needed substantial amounts of water at regular distances. As a result, many towns, such as Guthrie, Edmond, Oklahoma City, Moore (Verbeck), Norman (Norman's Camp), and Lexington were established along train routes (Edmond Historical Society, oral commun., 2009). Groundwater use from early statehood is difficult to evaluate because records are sparse or were not kept. Historical photographs can give some information about when and where groundwater withdrawal began. Photographs from the cities of Edmond (1889) and Moore (1900) show groundwater wells; Edmond's water well was hand dug with a diameter of 30 feet, a depth of 128 feet, and took 2 years to construct (Edmond Historical Society, oral commun., 2009).

Other central Oklahoma communities used groundwater as their initial source of water. Britton's first well was completed in 1900 (Gould, 1905) and Nichols Hills' first wells were drilled in 1938 (Wood and Burton, 1968). In addition, the City of Norman holds Oklahoma's oldest groundwater 'Prior Right', which was given a priority year of 1894 , indicating that Norman began using groundwater at that time. Midwest City, Del City, and what is now the Tinker Air Force Base area, which partly relied on groundwater, developed in the early 1940s as a result of war activities (Wood and Burton, 1968; Jacobsen and Reed, 1949).

Drought conditions in 1939-40 and again in the 1950s forced Oklahoma City, which at the time relied predominantly on surface-water sources, to drill groundwater wells to supplement the city's water supply (Jacobsen and Reed, 1949; Mogg and others, 1960; Wood and Burton, 1968). Since that time, Oklahoma City has relied increasingly on surface water and only maintains a few groundwater wells for possible future needs (Benham Engineering Company, Inc., and Black \& Veatch, 1967).
Some publications attempted to quantify early groundwater use, either from documentation or through estimation. Wood and Burton (1968) estimated that 279,000 acre-ft/yr were withdrawn from the Central Oklahoma aquifer in Cleveland and Oklahoma Counties between 1900 and 1959. Bureau of Reclamation (1958) estimated groundwater use for the bedrock part of the aquifer (Central Oklahoma aquifer) to have been 13,300 acre-ft/yr in 1953. C.H. Guernsey and Co. (1959) estimated use in 1959 for the two-county area (Oklahoma and Cleveland Counties) to have been about 17,900 acre-ft/yr. Much of the water use from 1938-63, approximately 40,000 acre-ft/yr, was used for oil field activities (Wood and Burton, 1968) with documented drawdowns of 35 feet in the Oklahoma City area (Jacobsen and Reed, 1949). In 1963, the cities of Edmond, Midwest City, Nichols Hills, and Norman, Tinker Air Force Base, and the University of Oklahoma reported groundwater use of 14,085 acre-ft/yr (Wood and Burton, 1968).

\section{Reported Groundwater Use}

Since 1967, users of groundwater that have permits have been required to submit their annual water use to the OWRB. Groundwater-use data were available from these annual wateruse reports submitted by permit holders to the OWRB and typically include public-water suppliers, irrigators, industry, and businesses. The term 'public-water supply' is used herein to describe groundwater use for drinking water by municipalities, rural water districts, housing additions, trailer parks, churches, and schools.

The OWRB reviewed, checked, and corrected groundwater-use data to ensure the quality of data included in the investigation described in this report. There were some cases where a permit holder failed to report water use to the OWRB, which are hereby referred to as unreported groundwater use. The OWRB attempted to acquire the missing unreported groundwater-use data by either requesting the information from the permit holders or retrieving monthly operational reports submitted by the municipalities to the Oklahoma Department of Environmental Quality. In cases where data could not be retrieved, an average of the intervening years for that permit holder was used to estimate the missing year's groundwater-use data, herein referred to as estimated unreported groundwater use.

Groundwater use from the Central Oklahoma aquifer bedrock and alluvium from 1967 to 2008, shown in figure 19, illustrates that most of the groundwater use was from the bedrock part of the aquifer (Central Oklahoma aquifer). Figure 20 shows groundwater use, including estimated unreported groundwater use, categorized by type: public-water supply, irrigation, industrial, power, mining, commercial, recreation, and estimated unreported. Average annual reported groundwater use from the aquifer from 1967 to 2008 was about 34,818 acre-ft/yr. Including estimated unreported groundwater use, average groundwater use from 1967 to 2008 was about 37,367 acre-ft/yr (table 3 ) with public-water supply consuming 


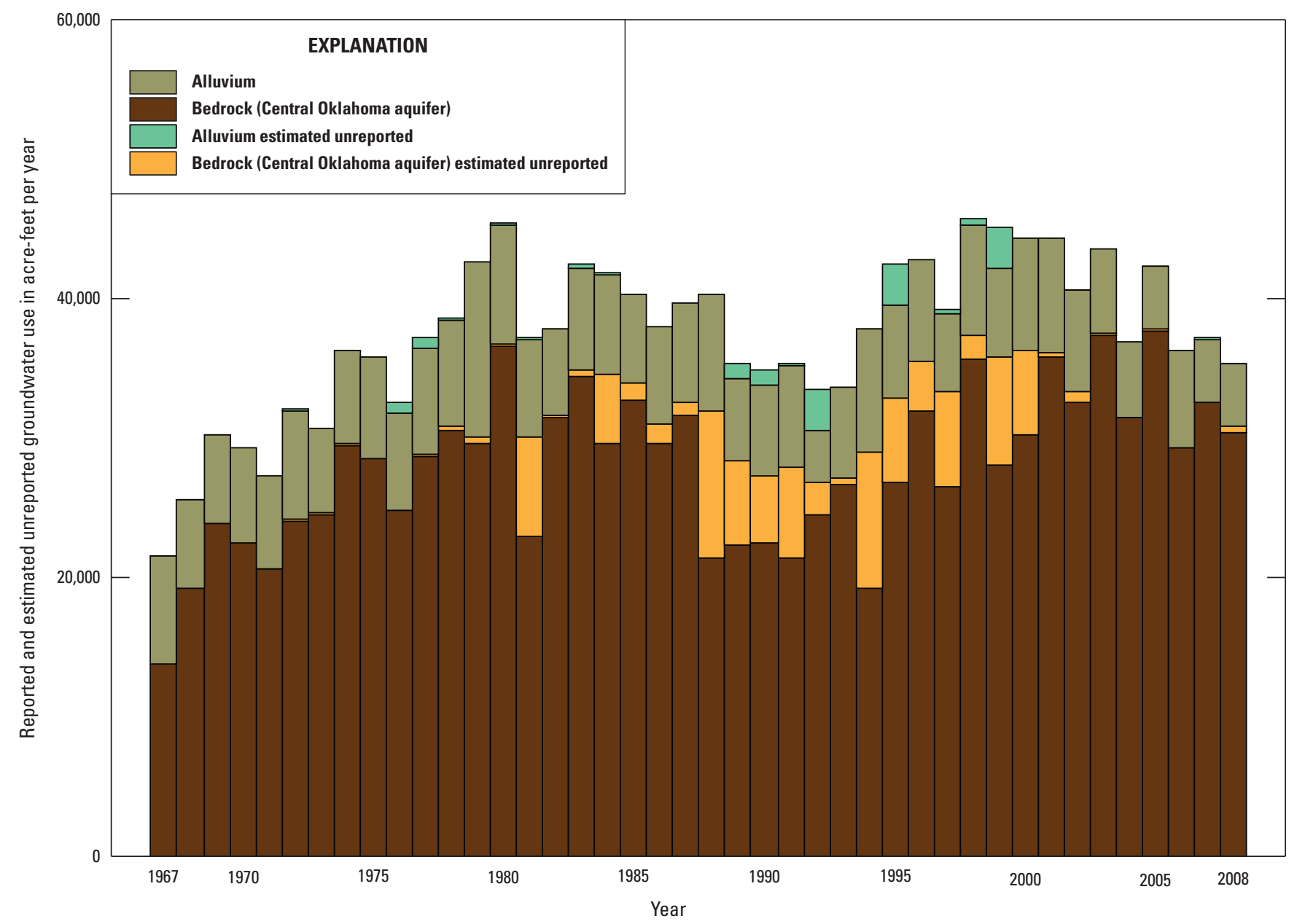

Figure 19. Groundwater use from alluvium and bedrock sources in the Central Oklahoma aquifer, 1967-2008.

23,367 acre-ft/yr (table 4), or about 63 percent of the average annual reported and estimated unreported groundwater use.

Average groundwater use increased steadily from 1967 through 1976 with an average of 30,148 acre-ft/yr (figs. 19 and 20). Public-water supply from 1967 through 1976 accounted for 52 percent of the reported and estimated groundwater use. Commercial use from 1967 through 1976 accounted for about 23 percent, largely because Tinker Air Force Base reported use as such (tables 3 and 4). Groundwater use from the aquifer during the 1977-88 period had an average annual reported groundwater use of about 40,113 acre-ft/yr. Public-water supply increased by about 55 percent from the 1967-76 period and accounted for 24,410 acre-ft/yr of use, or nearly 61 percent of the total use, whereas irrigation use increased by about 20 percent (tables 3 and 4). The peak groundwater use during this period was about 45,346 acre-ft/yr in 1980. Reported and estimated groundwater use decreased by 5,044 acre-ft/yr, about 13 percent, during the 1989-94 period. This decrease in groundwater use may be attributed to a wet period with increased rainfall and less reliance on groundwater by the City of Edmond because of construction of Lake Arcadia (see fig. 4 for location) as a water supply. During this 1989-94 period, public-water supply use of groundwater decreased by about 24 percent and unreported use was highest.

During the 1995-2008 period average annual groundwater use increased by about 6,086 acre-ft/yr (17 percent), with a peak of annual water use from the aquifer of about 45,642 acre-ft/yr in 1998. Public-water supply and irrigation use increased by about 62 percent and 30 percent, respectively, during the 1995-2008 period. Commercial water use decreased because before 1995, Tinker Air Force Base reported water use as commercial; afterward, its water use was reported as public-water supply. Industrial use decreased during each period from an average of 1,875 acre-ft/yr during 1967-76 to 343 acre-ft/yr during 1995-2008.

During the 1995 to 2008 period, public-water supply was the predominant use of groundwater that accounted for about 73 percent of reported and estimated use (fig. 21). Irrigation from 1995 to 2008 accounted for about 10 percent of groundwater use, with about one-half of that use being dedicated to golf courses. Other uses from 1995 to 2008 accounted for about 10 percent of reported and estimated groundwater use. 


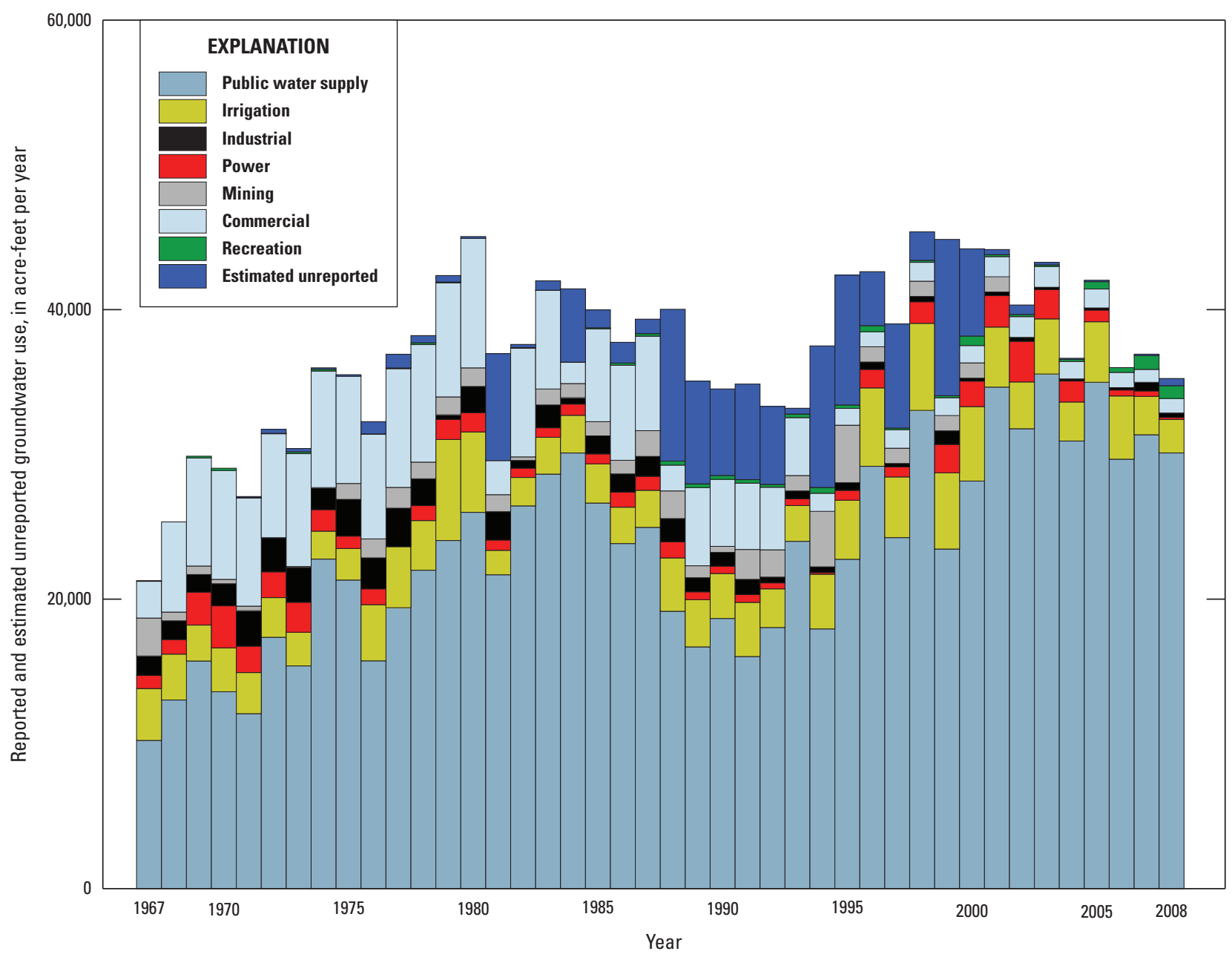

Figure 20. Groundwater use and estimated unreported use by type from the Central Oklahoma aquifer, 1967-2008.

Table 3. Reported and estimated groundwater-use statistics for the Central Oklahoma aquifer, 1967-2008.

\begin{tabular}{lccccc}
\hline \multirow{2}{*}{ Statistic } & \multicolumn{5}{c}{ Reported and estimated annual water use (acre-feet per year) } \\
\cline { 2 - 5 } & $\mathbf{1 9 6 7 - 2 0 0 8}$ & $\mathbf{1 9 6 7 - 7 6}$ & $\mathbf{1 9 7 7 - 8 8}$ & $\mathbf{1 9 8 9 - 9 4}$ & $\mathbf{1 9 9 5 - 2 0 0 8}$ \\
\hline Average & 37,367 & 30,148 & 40,113 & 35,069 & 41,155 \\
Median & 37,531 & 30,442 & 39,952 & 35,080 & 42,411 \\
Minimum & 21,576 & 21,576 & 37,234 & 33,542 & 35,360 \\
Maximum & 45,642 & 36,297 & 45,346 & 37,800 & 45,642 \\
\hline
\end{tabular}


Table 4. Average annual reported and estimated groundwater use by type for the Central Oklahoma aquifer, 1967-2008.

[PWS, public water supply]

\begin{tabular}{lccccccccc}
\hline \multirow{2}{*}{ Time span } & \multicolumn{7}{c}{ Average annual reported water use (acre-feet per year) } \\
\cline { 2 - 10 } & PWS & Irrigation & Industrial & Power & Mining & Commercial & Other & Estimated & Total \\
\hline $1967-76$ & 15,727 & 2,815 & 1,875 & 1,620 & 696 & 6,888 & 365 & 165 & 30,148 \\
$1977-88$ & 24,410 & 3,369 & 1,386 & 863 & 1,185 & 6,048 & 392 & 2,459 & 40,113 \\
$1989-94$ & 18,564 & 3,170 & 720 & 430 & 1,681 & 4,029 & 599 & 5,875 & 35,069 \\
$1995-2008$ & 29,989 & 4,108 & 343 & 1,289 & 738 & 1,209 & 581 & 2,904 & 41,155 \\
$1967-2008$ & 23,367 & 3,455 & 1,060 & 1,123 & 991 & 4,347 & 478 & 2,549 & 37,367 \\
\hline
\end{tabular}

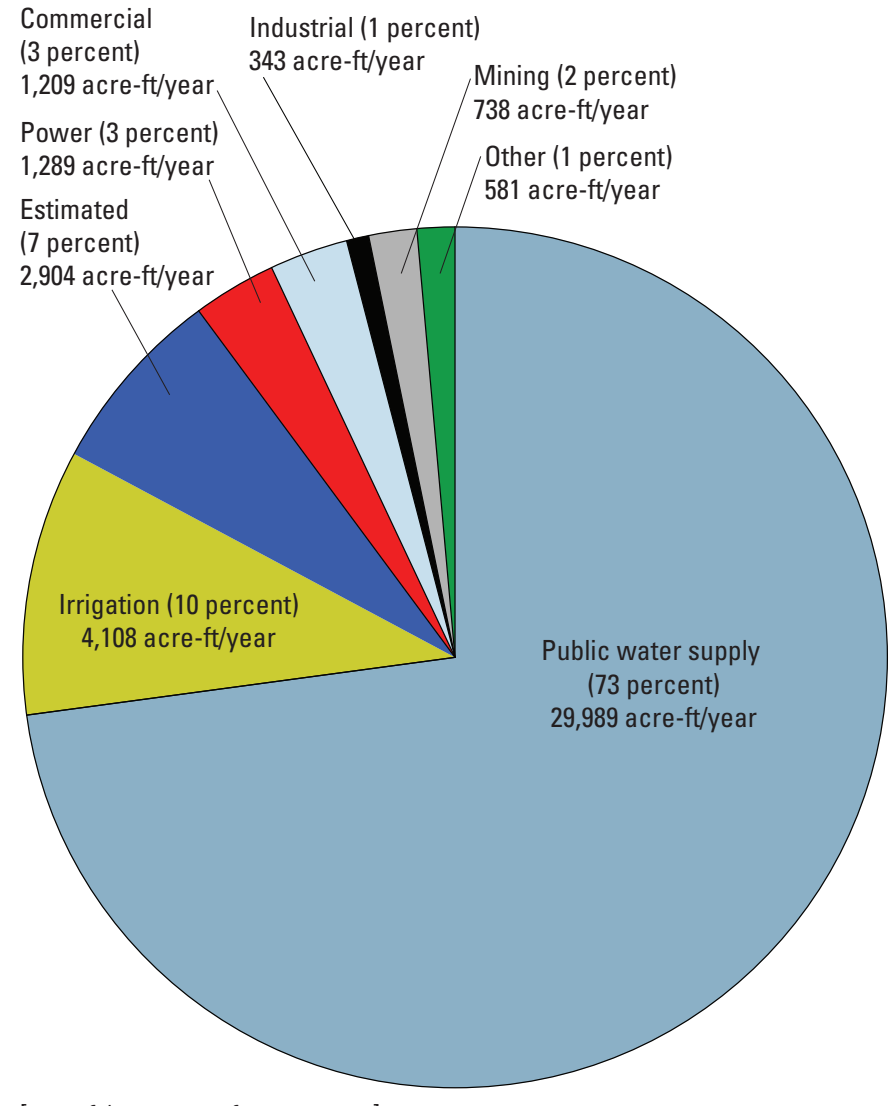

[acre-ft/year, acre-feet per year]

Figure 21. Average groundwater use by type from the Central Oklahoma aquifer, 1995-2008.
From 1995 to 2008, OWRB staff determined that 7 percent, or an average annual use of about 2,904 acre-ft/yr, was not reported. The years of greatest unreported groundwater were from 1988 to 2000, when an estimated average annual use of about 6,495 acre-ft/yr was not reported.

The two largest users of groundwater from the Central Oklahoma aquifer from 1995 to 2008 were the cities of Edmond and Moore (table 5 and fig. 22). Together, they accounted for about 10,780 acre-ft/yr, or about 26 percent of the reported and estimated unreported groundwater use. Nine of the ten highest users are public water providers; although Tinker Air Force Base (see fig. 1 for location) was one of the ten highest users, the base also uses water for other purposes. The largest users are located over the central part of the aquifer, where the largest deposits of sandstone facilitate larger withdrawals of water, described in more detail in the Hydrogeologic Framework section of this report.

A large portion of the water used from the aquifer serves public water-supply systems. Public water providers include the cities of Bethany, Del City, Edmond, Midwest City, Moore, Mustang, Norman, and Purcell, among others (fig. 22). Most of the public water-supply providers rely on the bedrock part of the aquifer to supply their needs. The City of Bethany, however, relies on water from the alluvium and terrace deposits of the North Canadian River.

Lake Arcadia (see fig. 6 for lake locations) was constructed in 1986 to augment the City of Edmond's groundwater demand, which increased during the 1970s and early 1980s. The rapid decline in groundwater use by Edmond is evident by the small consumption in 1989; however, by the late 1990s Edmond's groundwater demand had reached preLake Arcadia demand levels (fig. 23). Similarly, groundwater use by local municipalities probably declined after the construction of Lake Hefner (constructed in 1947), Lake Overholser (in 1919), Lake Stanley Draper (in 1962), and Lake Thunderbird (in 1965) (see fig. 6 for lake locations). In addition, the City of Oklahoma City currently (2013) sells treated surface water to surrounding municipalities. The purchase of treated surface water from Oklahoma City allows municipalities to pump less groundwater. 
Table 5. Largest users of groundwater from the Central Oklahoma aquifer from 1995 to 2008.

\begin{tabular}{lccc}
\hline \multirow{2}{*}{ Water user } & \multicolumn{3}{c}{ Reported and estimated annual water use (acre-feet per year) } \\
\cline { 2 - 4 } & Reported use & $\begin{array}{c}\text { Unreported } \\
\text { (estimated) use }\end{array}$ & $\begin{array}{c}\text { Sum of reported and } \\
\text { estimated use }\end{array}$ \\
\hline Edmond, City of & 5,998 & 0 & 5,998 \\
Moore, City of & 3,237 & 1,545 & 4,782 \\
Norman, City of & 3,132 & 207 & 3,339 \\
Bethany, City of & 2,317 & 429 & 2,746 \\
Tinker Air Force Base & 2,391 & 143 & 2,534 \\
Yukon, City of & 2,157 & 0 & 2,157 \\
Nichols Hills, City of & 2,000 & 0 & 2,000 \\
Oklahoma Gas \& Electric Company & 1,284 & 0 & 1,284 \\
Mustang, City of & 1,107 & 171 & 1,278 \\
Purcell, City of & 942 & 0 & 942 \\
\hline
\end{tabular}

\section{Domestic Groundwater Use}

Domestic use from self-supplied wells (does not include domestic use from public supply) was estimated for input into the groundwater-flow model by using the 1990 census longform (http://www.census.gov/prod/1/90dec/cph4/appdxe.pdf) data and compared population changes from 1980, 2000, and 2010 census data.

The extrapolation method for estimating domestic groundwater use assumes that the population outside of the municipal water-supply service areas obtains water from domestic wells. The areas of high domestic use identified using this method coincide with the number of groundwater wells constructed in the Central Oklahoma aquifer. The patterns observed in the estimated domestic groundwater use are caused by increasing population in the suburban areas surrounding Oklahoma City. Development of water supplies east of Norman has continued to increase as well as east of Edmond, Oklahoma. Continued development in areas with higher domestic use potentially may lead to interferences of drawdown between domestic wells.

The census long-form questionnaire is a combination of the basic short-form questionnaire plus about 50 additional questions on socioeconomic and housing characteristics. The long form was distributed to about 15 percent of the population; the data from the long form are weighted to represent an estimate of the total population in a particular census tract. A census tract is a geographic region defined for the purpose of taking a census and usually coincides with city and town limits or other administrative areas. The 1990 census longform questionnaire contained a question on source of water, whether supplied by municipal or individual well. The 1990 census long-form questionnaire was the only questionnaire that included a question on source of water. There were no questions of this nature on the 1980, 2000, or 2010 long-form questionnaire. The primary data used from the 1990 census to estimate domestic use for this investigation were the total population per census tract and the source of water. The 1990 census data consisted of additional options to designate number of housing units served by a public or private water supply entity, number of housing units supplied by a drilled groundwater well (drilled wells are usually less than 1.5 feet in diameter), number of housing units supplied by a dug well (dug wells are usually larger than 1.5 feet in diameter and hand dug), and number of housing units supplied by other sources. For this investigation, the population per census tract was divided by the sum of housing units to obtain the number of persons per housing unit. The persons per housing unit number was multiplied by the sum of housing units supplied by a groundwater well and housing units supplied by a dug well to obtain the population served by a domestic well. Land area for each 1990 census tract was divided into the population served by a domestic well for each tract to estimate population served by a domestic well per square mile. The estimated 1990 population served by a domestic well per square mile from census data were distributed across a $3,280-\mathrm{ft}$ by $3,280-\mathrm{ft}$ (1-km by $1-\mathrm{km}$ ) grid (fig. 24).

Total population for 1990, 2000, and 2010 was used similarly to derive gridded total population datasets. The 1980 census dataset (U.S. Census Bureau, 2013) was only available with county population. The gridded total population datasets were used to calculate a percent change from 1980-90, 1990-2000, and 2000-10. The 1980-90 (fig. 25) and 1990-2000 (fig. 26) population change grids were applied to the grid of the 1990 population served by domestic well to derive gridded 1980 and 2000 population served by a domestic 


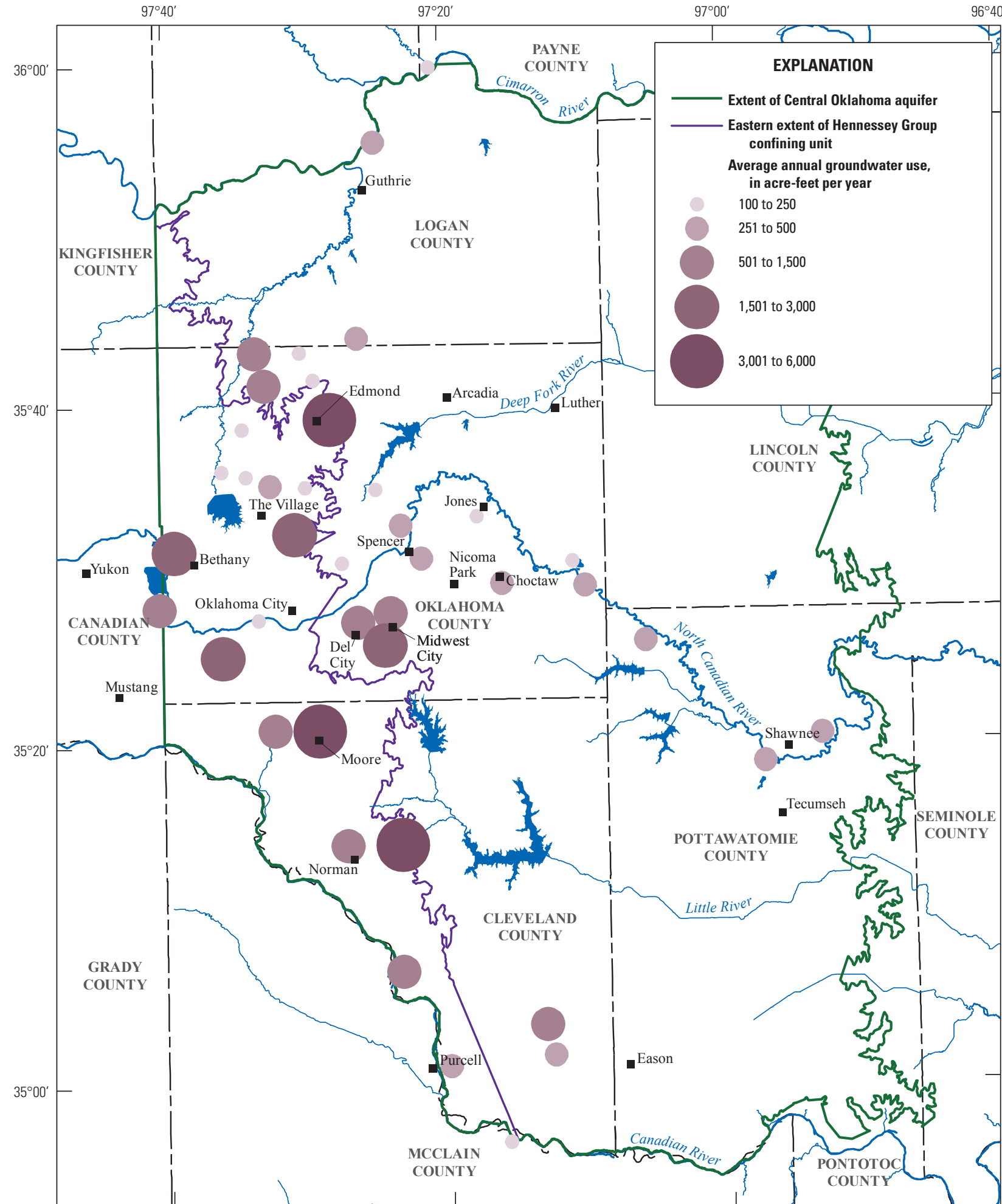

Base from Horizon Systems Corporation, 2010, and $\quad 0 \quad 4 \quad 16$ MILES Central Oklahoma aquifer and Hennessey boundaries University of Oklahoma Center for Spatial Analysis, 2013 Universal Transverse Mercator projection, Zone 14

North American Datum of 1983

Figure 22. Average annual reported groundwater use by permitted user greater than 100 acre-feet/year from the Central Oklahoma aquifer, 1995-2008. 


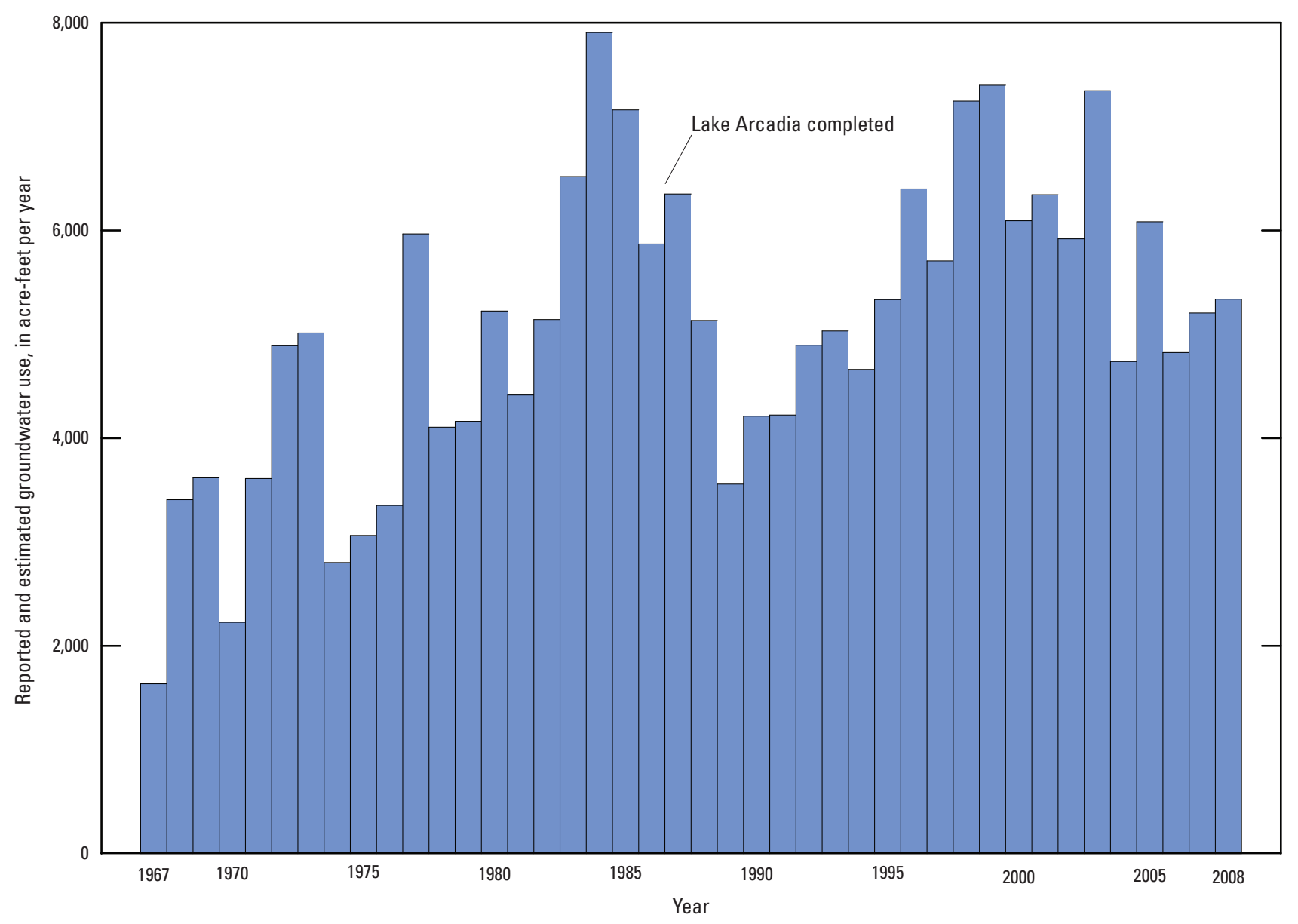

Figure 23. Groundwater use by the City of Edmond from 1967-2008.

well (fig. 27). The 2000-10 population change was applied to the 2000 estimated population served by a domestic well grid to derive the 2010 population served by a domestic well estimate (fig. 28). This method assumes that the rate of change in population changes similarly to the rate of change in population served by domestic wells.

An understanding of domestic water use from the Central Oklahoma aquifer can be obtained by examining domesticuse population density. In 1990, the areas of high domestic use based on 1990 census data are as follows: (1) along the I-35 corridor (shown on fig. 1) from northeast Oklahoma City, Okla. and west of Spencer to the Oklahoma and Logan county line, (2) an area north of Edmond, Okla. and south of Guthrie, Okla., known as Deer Creek, and (3) east of Oklahoma City near Spencer, Nicoma Park, and Choctaw, Okla. (fig. 24). Extrapolating to 2000, the estimated population served by a domestic groundwater well increased in the area east of Edmond, Okla. and to the west of Lake Arcadia, the area of southeast Oklahoma County and northeast Cleveland County, east of Norman, Okla., south of Moore, Okla., and western Logan County (fig. 27). The estimated domestic population using water from domestic wells in 2010 continued to increase in the area north of Edmond, Okla. and south of Guthrie, Okla. as well as southeast Oklahoma County and areas around and west of Moore, Okla. (fig. 28).

The grids of population served by domestic wells for $1980,1990,2000$, and 2010 needed a per capita daily wateruse rate to determine the domestic-use rate for those years. Estimates of per capita daily water use vary substantially. Stoner (1984) used 61 gallons per capita per day (gpcd) based on several methods, including those of Babbitt and Doland (1955) and Steel (1947). Kenny and others (2009) report 85 gpcd for Oklahoma based on regional methods to determine domestic per capita use rate. They define domestic use as including "indoor and outdoor uses at residences... either self-supplied or provided by public providers." The methods used to derive 85 gpcd were provided by the USGS (R.L. Tortorelli, U.S. Geological Survey, written commun., 2009). The methods for Oklahoma did not distinguish between 'self-supplied' and 'public-supplied' as is the case with other states (Tortorelli, 2009). Kenny and others (2009) indicate a national average for self-supplied and public-supplied use of 89 gpcd and 99 gpcd, respectively. As a result, applying an allencompassing rate derived for Oklahoma may skew the results higher where a 'self-supplied' rate may be more realistic for domestic use. 


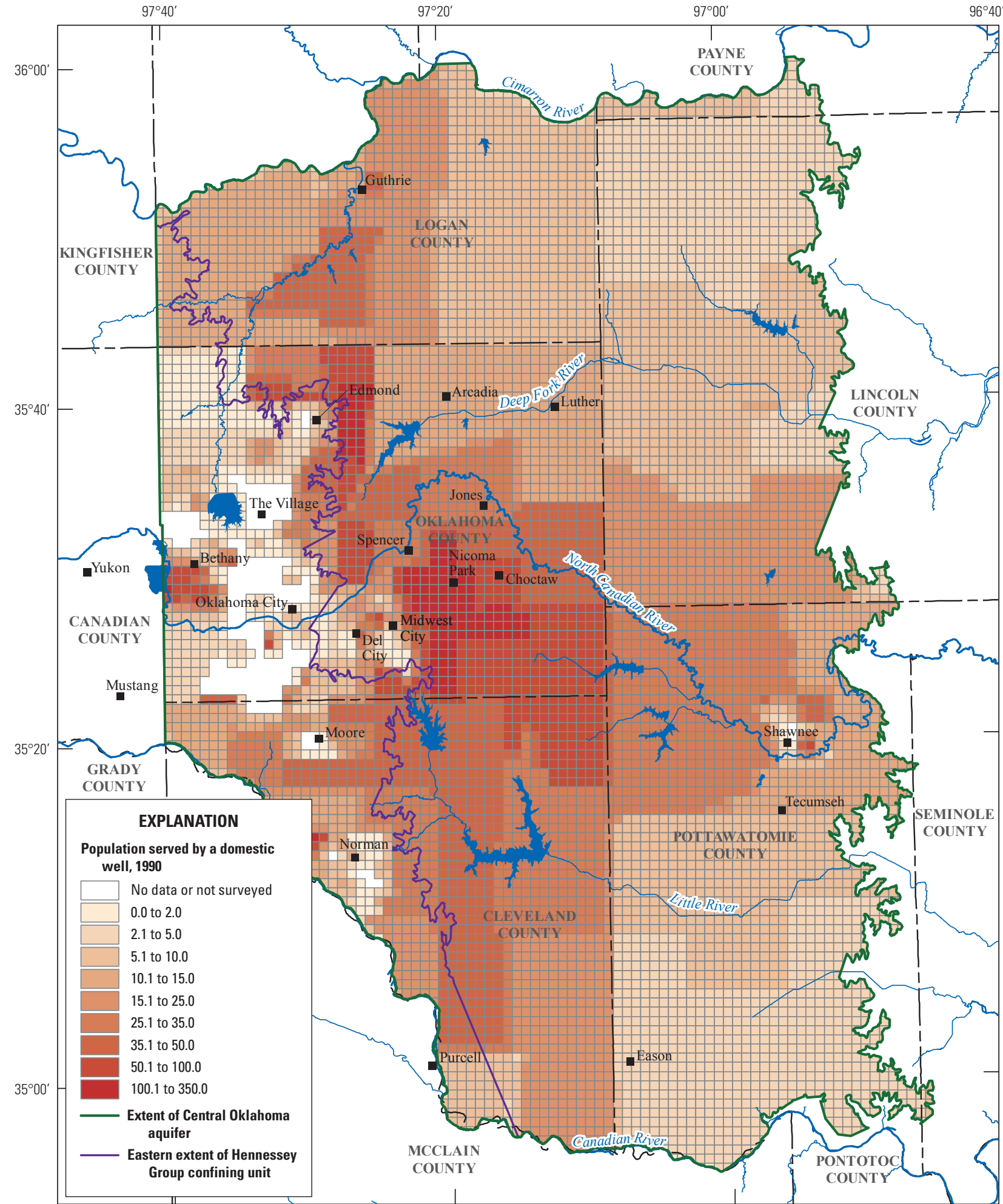

Base from Horizon Systems Corporation, 2010, and University of Oklahoma Center for Spatial Analysis, 2013 Universal Transverse Mercator projection, Zone 14

North American Datum of 1983

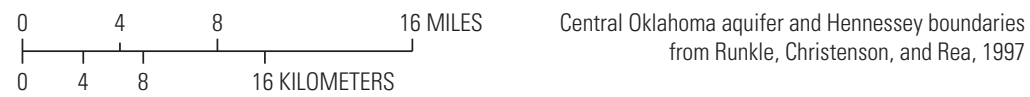

Figure 24. Population served by domestic wells during the year 1990 (per 3,280-foot by 3,280-foot grid) (U.S. Census Bureau, 2013). 


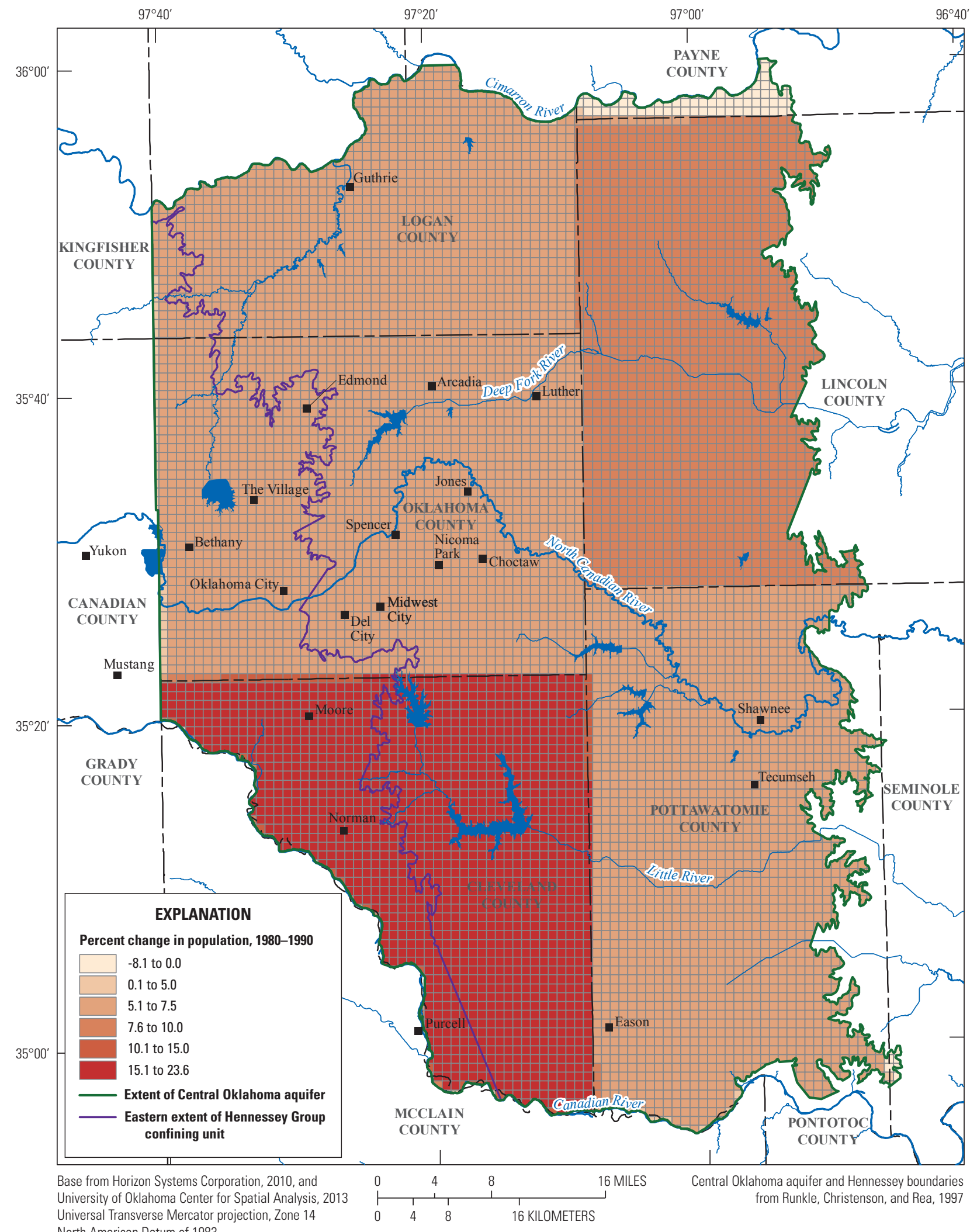

North American Datum of 1983

Figure 25. Percent change in population from 1980 to 1990 (per 3,280-foot by 3,280-foot grid) (U.S. Census Bureau, 2013). 


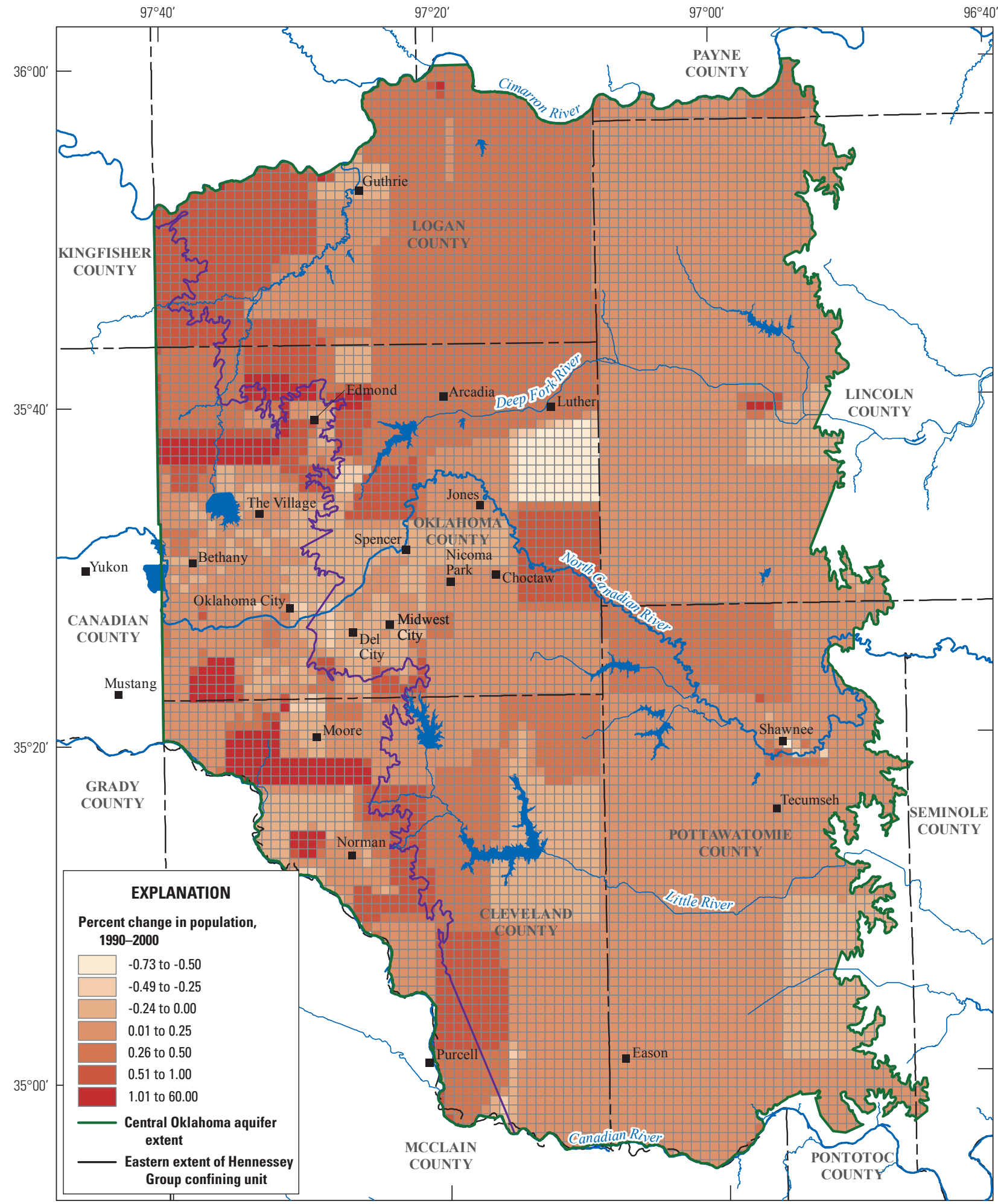

Base from Horizon Systems Corporation, 2010, and University of Oklahoma Center for Spatial Analysis, 2013 Universal Transverse Mercator projection, Zone 14

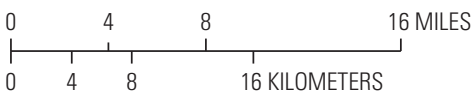

Central Oklahoma aquifer and Hennessey boundaries from Runkle, Christenson, and Rea, 1997 North American Datum of 1983

Figure 26. Percent change in population from 1990 to 2000 (per 3,280-foot by 3,280-foot grid) (U.S. Census Bureau, 2013). 


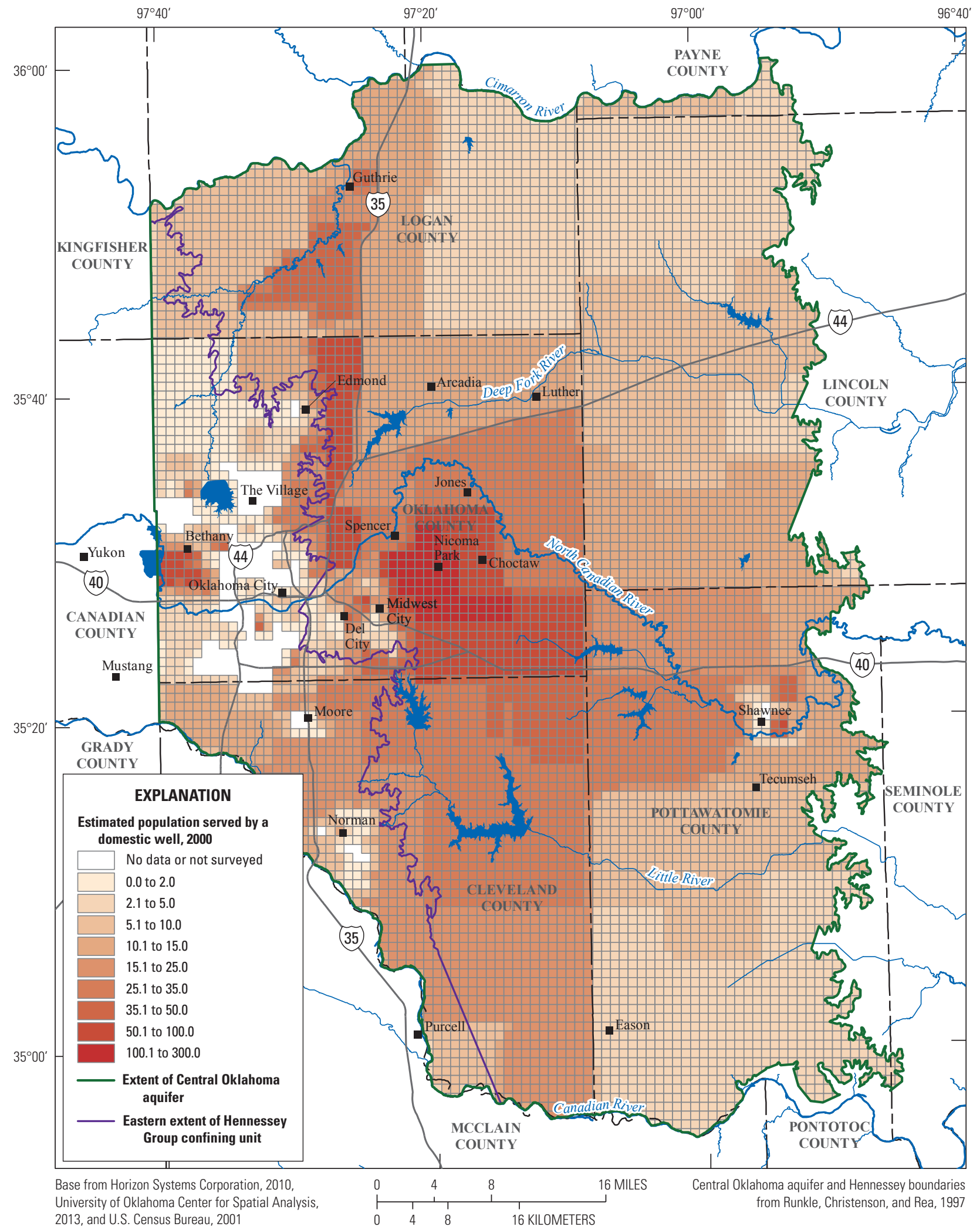

Universal Transverse Mercator projection, Zone 14

North American Datum of 1983

Figure 27. Estimated population served by domestic wells during the year 2000 (per 3,280-foot by 3,280-foot grid). 


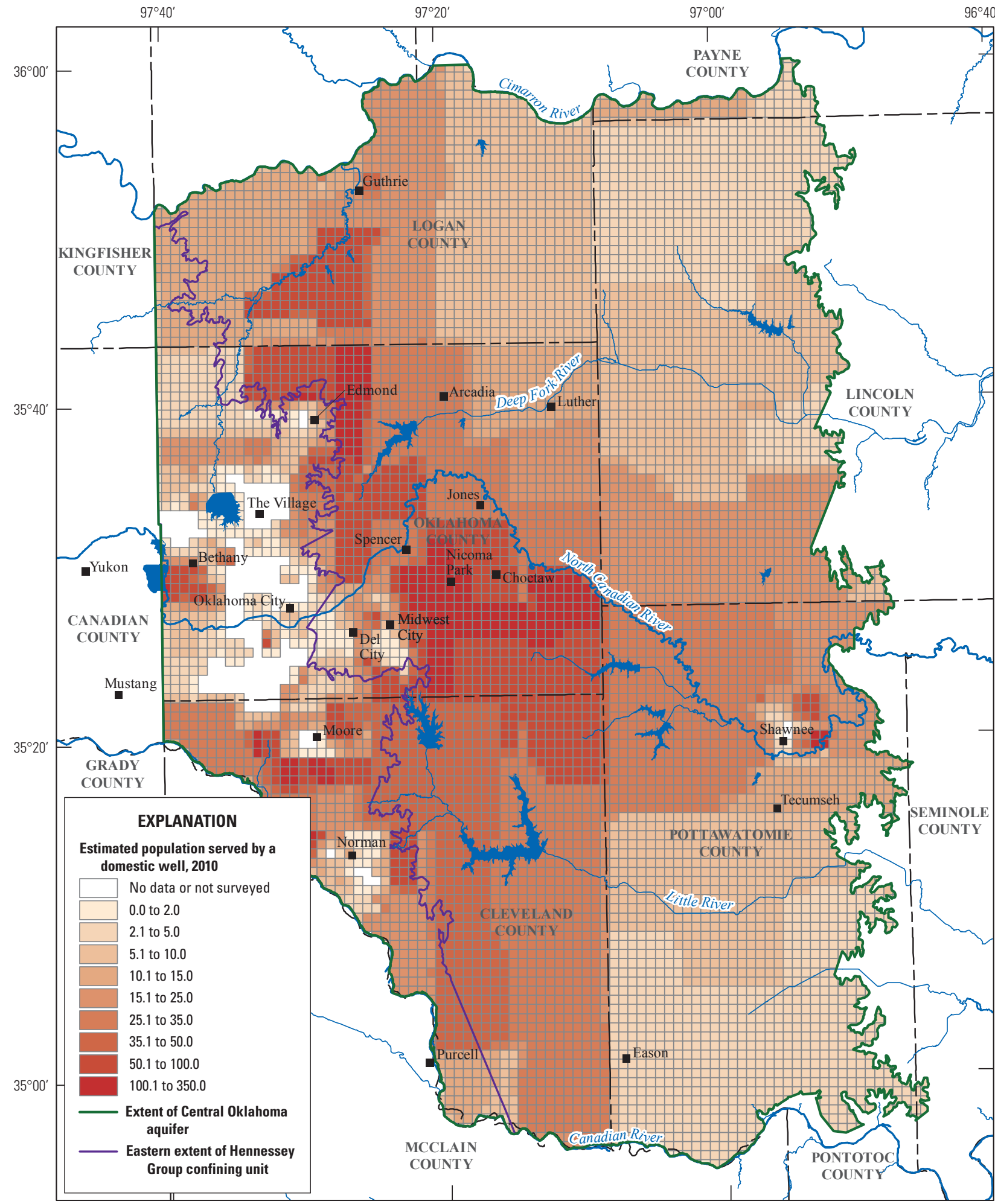

Base from Horizon Systems Corporation, 2010, and University of Oklahoma Center for Spatial Analysis, 2013 Universal Transverse Mercator projection, Zone 14

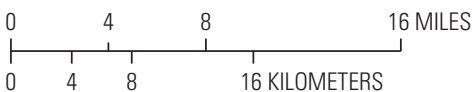

Central Oklahoma aquifer and Hennessey boundaries from Runkle, Christenson, and Rea, 1997 North American Datum of 1983

Figure 28. Estimated population served by domestic wells during the year 2010 (per 3,280-foot by 3,280-foot grid). 
For the Oklahoma Comprehensive Water Plan Report on the Central Watershed Planning Region (Oklahoma Water Resources Board, 2011), public-water supply entities were surveyed to determine daily per capita water use. In the Central Watershed Planning Region, major public water suppliers in the Central Oklahoma aquifer reported a range from 50 to 216 gpcd with an average and median of 121 and 116 gpcd, respectively. However, these per capita water uses do not represent domestic residential use because most entities did not differentiate between use classes, such as industrial, commercial, and residential uses.
The City of Edmond, Oklahoma provided their water-use data from 2006 to 2010 (Fred Rice, City of Edmond, written commun., 2011). Categorized data were provided by commercial, industrial, public, and residential meters. Based on Edmond's 2010 population of 81,405, residential daily per capita water use in 2010 was 94.7 gallons. The 3-month period with the lowest rate was January to March (56.3 gpcd) and the highest 3-month water-use period was August to October (143.5 gpcd).

Identifying an appropriate daily per-capita water-use rate to estimate domestic use is problematic; lower estimates tend to be limited to basic everyday residential needs, such as personal hygiene and laundry, whereas the larger quantities

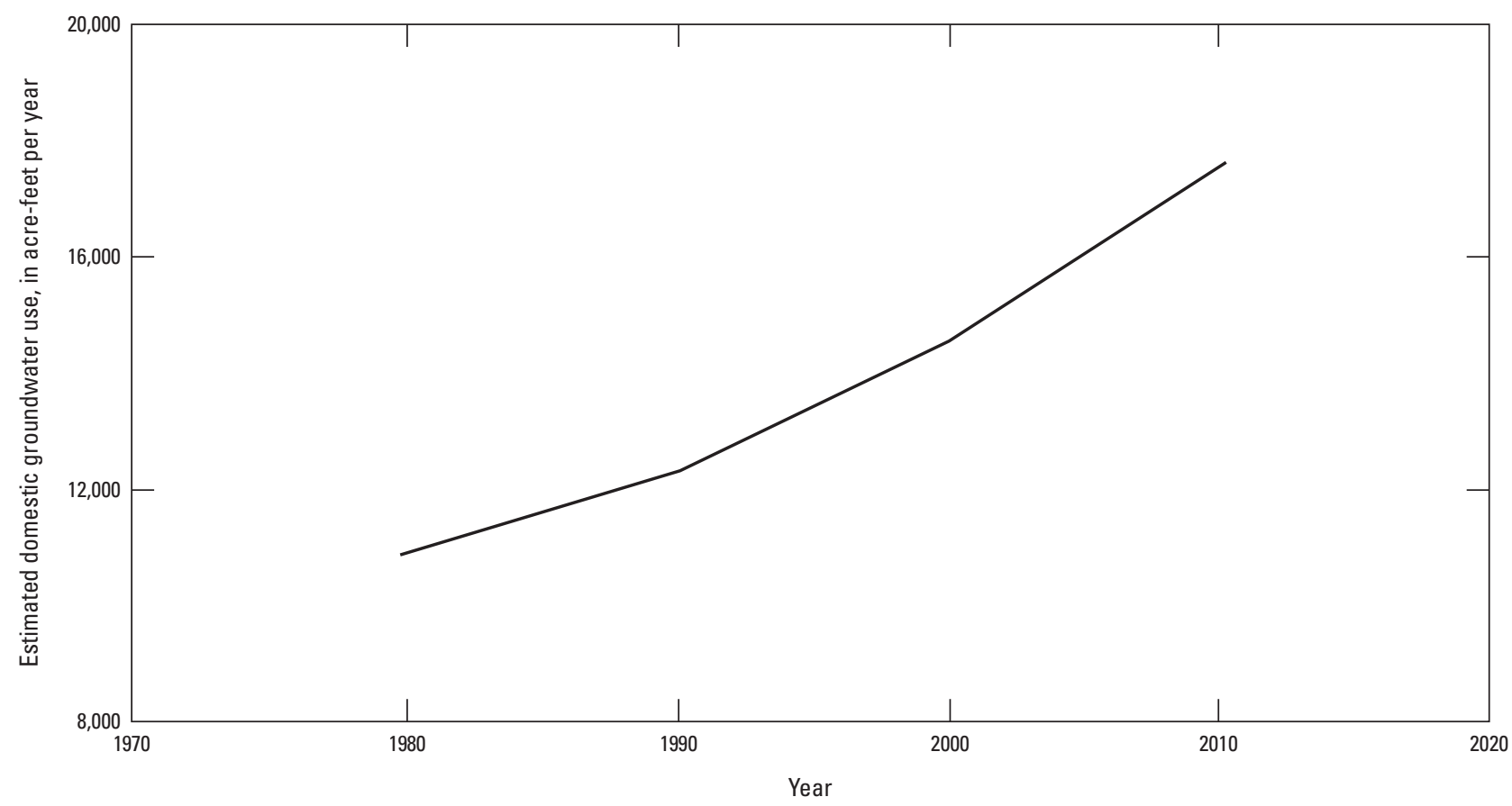

Figure 29. Estimated domestic use derived for the Central Oklahoma aquifer from the 1980, 1990, 2000, and 2010 U.S. Census Bureau data.

Table 6. Cumulative population data and estimated domestic water use derived from the 1980, 1990, 2000, and 2010 census for the Central Oklahoma aquifer.

[--, not applicable]

\begin{tabular}{|c|c|c|c|c|c|c|c|}
\hline Data type & 1980 & $\begin{array}{c}\text { Percent change } \\
1980-1990\end{array}$ & 1990 & $\begin{array}{c}\text { Percent change } \\
1990-2000\end{array}$ & 2000 & $\begin{array}{c}\text { Percent change } \\
2000-2010\end{array}$ & 2010 \\
\hline Total population & 793,198 & 9.77 & 870,699 & 12.42 & 978,852 & 12.09 & $1,097,198$ \\
\hline $\begin{array}{l}\text { Estimated domestic use } \\
\text { (acre-feet per year)* }\end{array}$ & 10,756 & -- & 12,269 & -- & 14,478 & -- & 17,506 \\
\hline
\end{tabular}

*Domestic use estimated using 85 gallons per capita per day. 
reported by water-supply entities commonly include commercial and industrial use, as well as lawn irrigation. The estimate of 85 gpcd for Oklahoma (Kenny and others, 2009) is similar to the values derived for the City of Edmond and Oklahoma Comprehensive Water Plan reported values of dominantly rural public water-supply entities, such as the City of Harrah, Oklahoma (73 gpcd) (see fig. 1 for town locations) and the Town of Jones, Oklahoma (88 gpcd) (Oklahoma Water Resources Board, 2011). Therefore, a daily per capita wateruse rate of 85 gallons was multiplied by the grids of population served by domestic wells for 1980, 1990, 2000, and 2010 to estimate domestic use per 3,280-ft by 3,280-ft (1-km by $1-\mathrm{km}$ ) grid for the Central Oklahoma aquifer (fig. 29 and table 6). Average estimated domestic groundwater use from the aquifer in 1990 derived from census data was $12,269 \mathrm{acre}-\mathrm{ft} / \mathrm{yr}$. The average domestic groundwater use for 1980 to 2010 was estimated to be about 13,752 acre-ft/yr.

\section{Streamflow and Base Flow}

The major streams flowing across the Central Oklahoma aquifer are the Cimarron River, North Canadian River, and Canadian River. The flows in these streams are regulated by dams and increased by releases from sewage-treatment plants. Streamflow data are presented in this section to provide an estimate of the streamflow magnitudes in the Central Oklahoma aquifer study area. The streamflow data presented in table 7 are summarized through 2009 from the USGS Annual Water Data Report (U.S. Geological Survey, 2010a).

Streamflow at the North Canadian River below Lake Overholser near Oklahoma City, Okla., streamflow-gaging station 07241000 (fig. 30) is regulated by Canton Lake (not shown on figures, outside of map extents), Lake Overholser, and flow diversions upstream from the streamflow-gaging station into Lake Overholser and Lake Hefner Canal. Days with no streamflow were documented at the North Canadian River below Lake Overholser near Oklahoma City, Okla., streamflow-gaging station during the 1953-55 water years. Streamflow at the Canadian River at Bridgeport, Okla., streamflow-gaging station (07228500) has been regulated upstream by Lake Meredith, Texas since 1964 (not shown on figures, outside of map extents). Streamflow at the Deep Fork at Warwick, Okla., streamflow-gaging station (07242380) has been regulated by Arcadia Lake from 1986 to present (2013). Streamflow at the Little River below Lake Thunderbird near Norman, Okla., streamflow-gaging station (07230000) has been regulated by Lake Thunderbird since 1965. Average daily mean streamflow in the study area ranged from 55.8 cubic feet per second $\left(\mathrm{ft}^{3} / \mathrm{s}\right)$ at streamflow-gaging station 07230000 for the period 1966-2009 to $255 \mathrm{ft}^{3} / \mathrm{s}$ at streamflow-gaging station 07242380 for the period 1988-2009. Total 2009 (water year) annual streamflow in the study area ranged from 6.9 million acre-ft at streamflow-gaging station 07230000 to 35.5 million acre-ft at streamflow-gaging station 07242380.
The part of streamflow that is discharged from groundwater is referred to as base flow. Base flow, for this report, is defined as the part of streamflow that is not from runoff. Discharge components of the Central Oklahoma aquifer consist of evaporation, plant transpiration, groundwater withdrawals, and discharge to streams. During the winter months, evaporation, plant transpiration and withdrawals from the shallow part of the aquifer (most regulated withdrawals are from the deeper parts of the aquifer) are considered to be minimal and discharge measurements were made when the runoff part of streamflow was considered to have dissipated. Discharge measurements made in unregulated streams during these conditions also are referred to as base flow, in which the entire flow in the stream channel is inferred to be groundwater discharge (table 8). Discharges measured in January 2009 in the study area during base-flow conditions ranged from $0.23 \mathrm{ft}^{3} / \mathrm{s}$ at streamflow-gaging station 07241570 Deer Creek near Newalla, Okla., to $4.46 \mathrm{ft}^{3} / \mathrm{s}$ at streamflow-gaging station 07242378 Captain Creek near Wellston, Okla. Base flow is the largest water discharge by the Central Oklahoma aquifer (Parkhurst and others, 1996).

\section{Recharge}

Recharge, for the investigation described in this report, is the process by which precipitation enters the groundwater-flow system at the upper zone of saturation. Recharge in the Central Oklahoma aquifer can be inferred to exist from two main processes: (1) infiltration of streamflow through stream channels and lake beds, and (2) infiltration of precipitation through the unsaturated zone above the aquifer. Factors that affect recharge are precipitation rates and amounts, vertical hydraulic conductivity, moisture capacity of the unsaturated zone, and slope of the land surface. Recharge is difficult to quantify and measure directly because recharge rates vary over short spatial and temporal scales, but there are several methods that can be used to estimate recharge rates. Some methods attempt to capture recharge rates at specified points and some methods estimate recharge at the basin or regional scale. Either of these types of methods can vary in timescale from hours to days.

In many drainage basins a substantial proportion of base flow began as groundwater recharge. Using base flow to estimate recharge requires several assumptions. First, base flow to a stream is assumed to be derived from the areally distributed recharge over the area of the basin and not from the regional flow system. Second, minimal water consumption and discharge is assumed, such as plant evapotranspiration or pumping wells in a basin. Lastly, recharge entering the saturated zone of the aquifer is assumed to discharge to the stream as base flow and does not leave the basin as part of the regional flow system. This method does not work well for losing streams, but the streams overlying the Central Oklahoma aquifer are assumed to be mostly gaining streams. Water lost to, or gained from these other sources is assumed to be less 


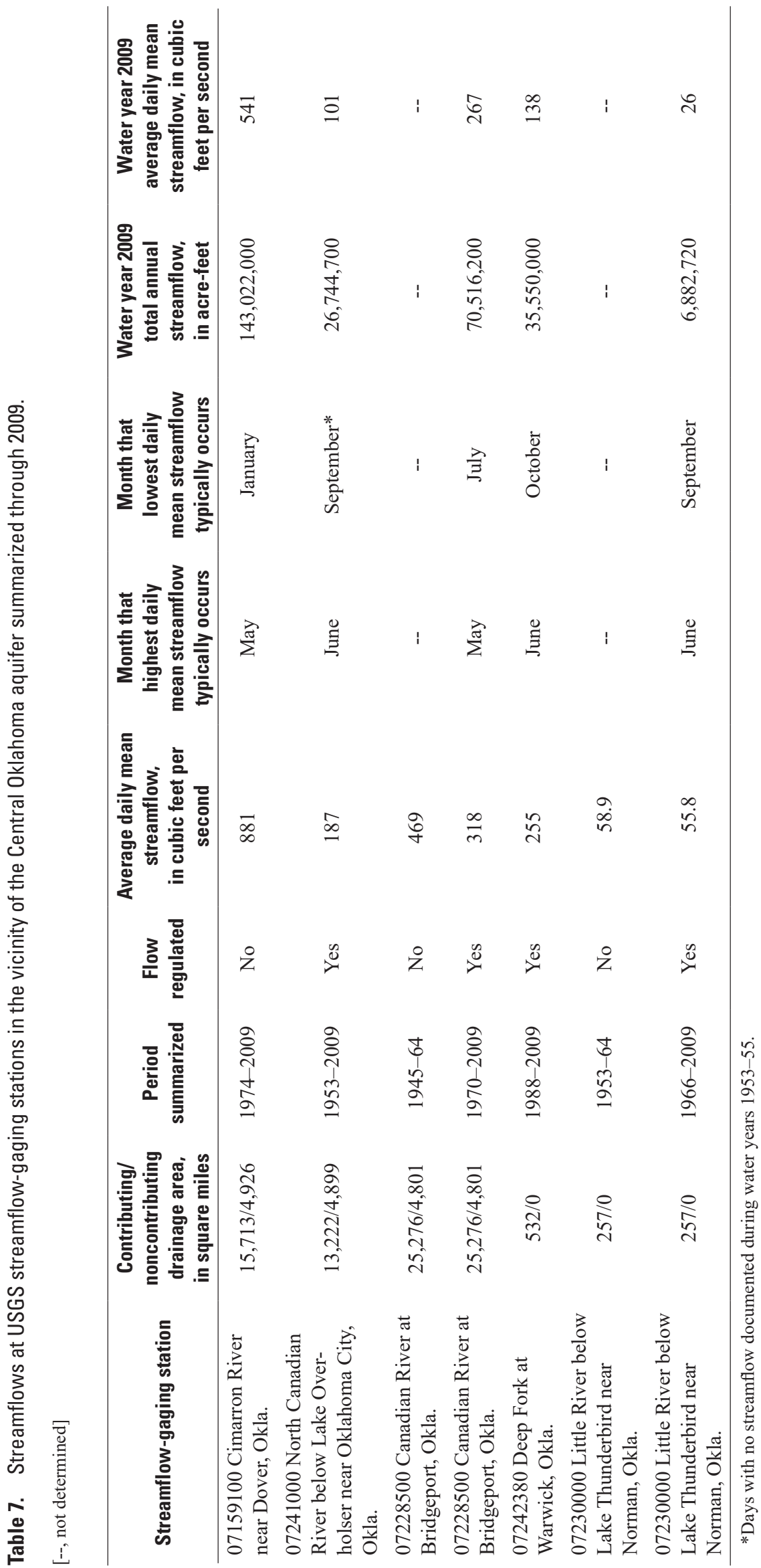




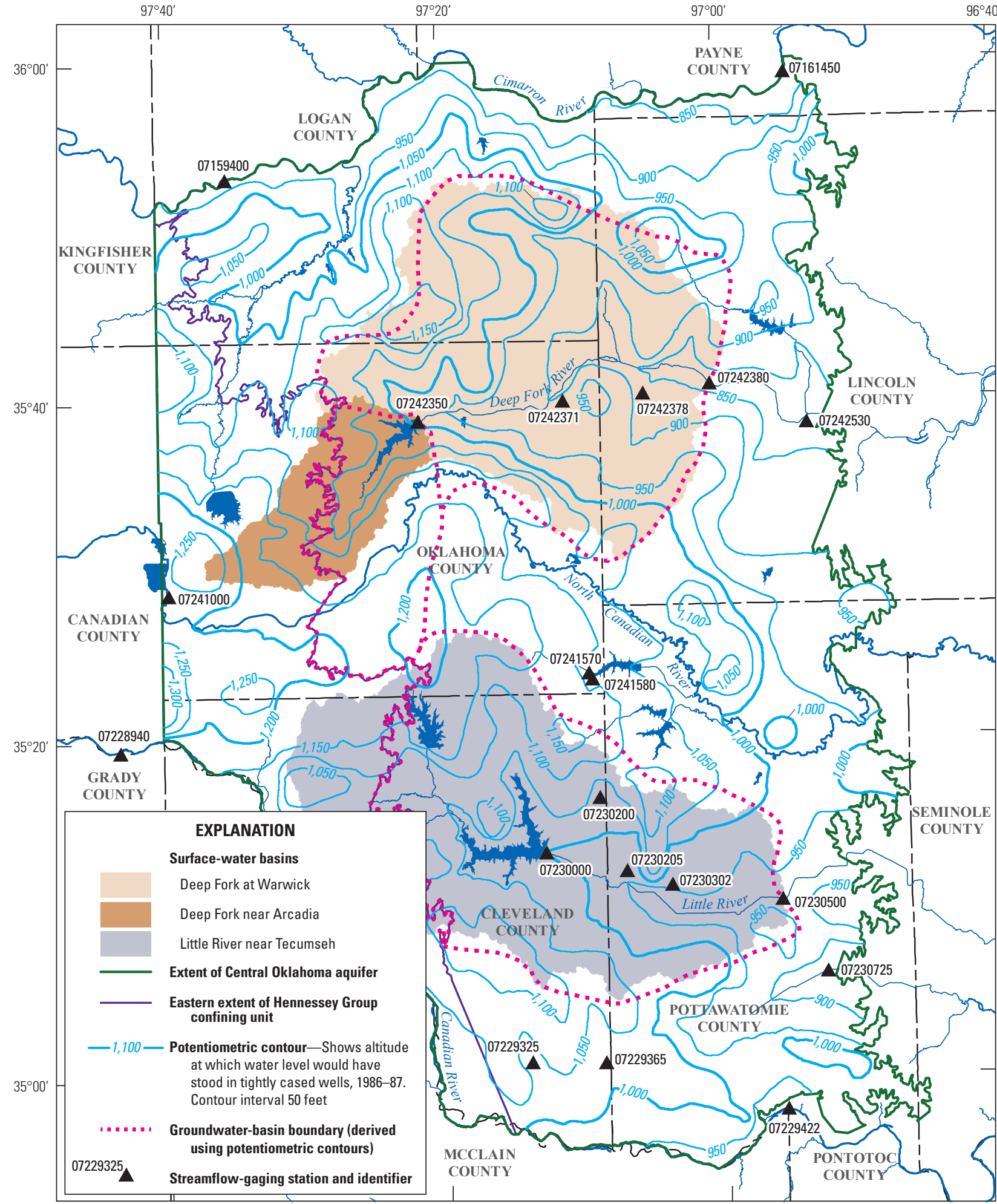

Base from Horizon Systems Corporation, 2010, and University of Oklahoma Center for Spatial Analysis, 2013 Universal Transverse Mercator projection, Zone 14

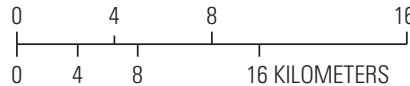

16 MILES

Central Oklahoma aquifer and Hennessey boundaries from Runkle, Christenson, and Rea, 1997

North American Datum of 1983

Potentiometric contours from Christenson and others, 1992

Figure 30. U.S. Geological Survey streamflow-gaging stations and selected surface-water basins and groundwater basins in the Central Oklahoma aquifer. 


\section{Hydrogeology and Simulation of Groundwater Flow in the Central Oklahoma (Garber-Wellington) Aquifer, Oklahoma}

Table 8. Streamflow measurements (at base flow) and calculated recharge rates from small selected streams located near the Central Oklahoma aquifer.

[--, recharge rate not calculated]

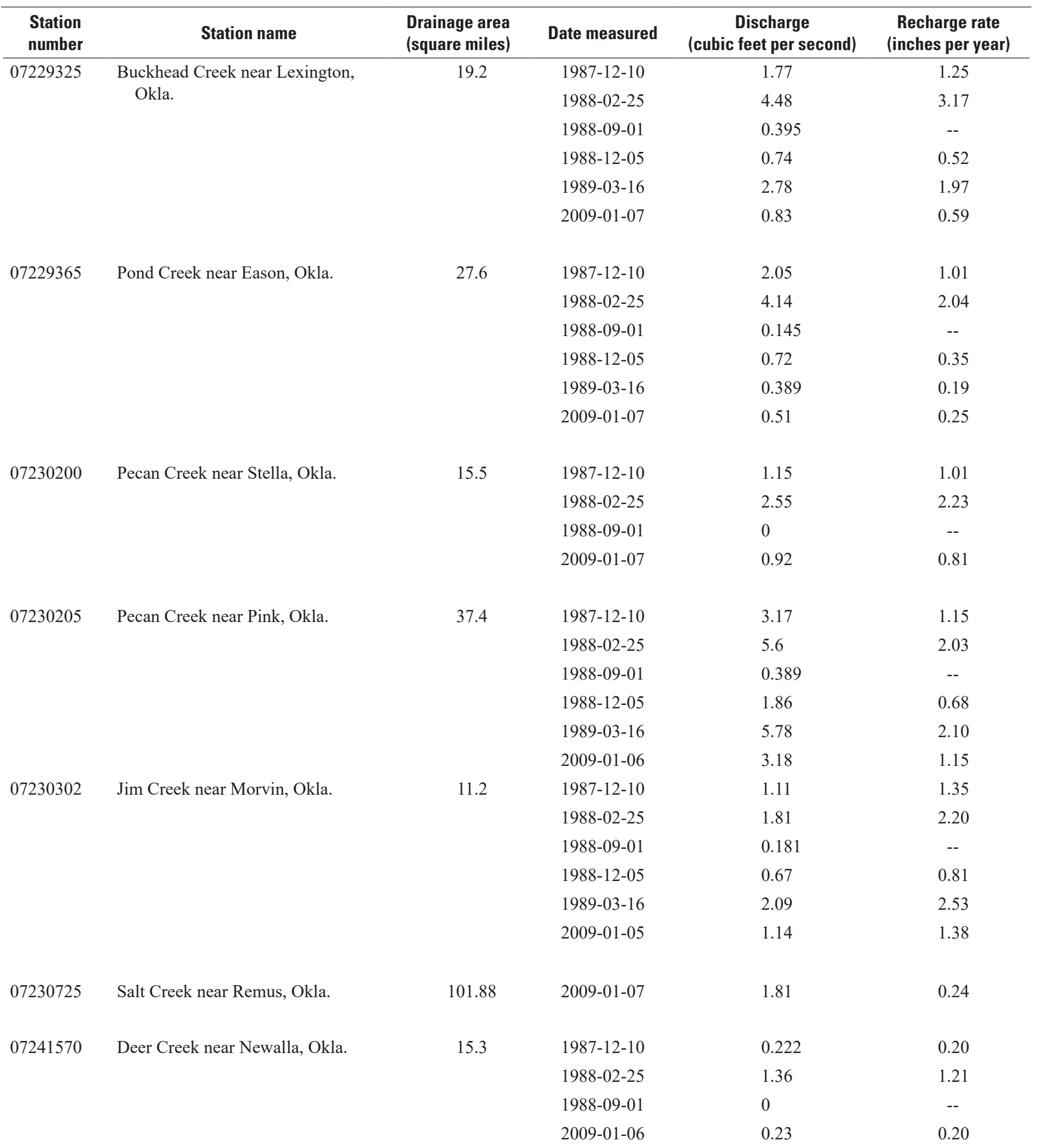


Table 8. Streamflow measurements (at base flow) and calculated recharge rates from small selected streams located near the Central Oklahoma aquifer-Continued

$[--$, recharge rate not calculated $]$

\begin{tabular}{|c|c|c|c|c|c|}
\hline $\begin{array}{l}\text { Station } \\
\text { number }\end{array}$ & Station name & $\begin{array}{l}\text { Drainage area } \\
\text { (square miles) }\end{array}$ & Date measured & $\begin{array}{c}\text { Discharge } \\
\text { (cubic feet per second) }\end{array}$ & $\begin{array}{l}\text { Recharge rate } \\
\text { (inches per year) }\end{array}$ \\
\hline \multirow[t]{3}{*}{07241580} & \multirow{3}{*}{$\begin{array}{l}\text { Unnamed tributary to Deer Creek } \\
\text { near Newalla, Okla. }\end{array}$} & \multirow[t]{3}{*}{8.7} & $1987-12-10$ & 0.163 & 0.25 \\
\hline & & & 1988-09-01 & 0 & -- \\
\hline & & & 2009-01-06 & 0.54 & 0.84 \\
\hline \multirow{4}{*}{07242371} & \multirow{4}{*}{ Wildhorse Creek at Luther, Okla. } & \multirow{4}{*}{18.2} & $1988-02-25$ & 4.06 & 3.03 \\
\hline & & & 1988-09-01 & 0.86 & -- \\
\hline & & & $1988-12-05$ & 2.89 & 2.16 \\
\hline & & & 1989-03-16 & 3.82 & 2.85 \\
\hline \multirow{5}{*}{07242378} & \multirow{5}{*}{ Captain Creek near Wellston, Okla. } & \multirow{5}{*}{57.9} & 1988-02-25 & 10.9 & 2.56 \\
\hline & & & 1988-09-01 & 1.13 & -- \\
\hline & & & $1988-12-05$ & 6.11 & 1.43 \\
\hline & & & 1989-03-16 & 11.4 & 2.67 \\
\hline & & & 2009-01-06 & 4.46 & 1.05 \\
\hline
\end{tabular}

than the total recharge-base-flow relation, and thus the base flow is an approximation of surface recharge.

Several basin-scale methods were used to quantify average annual recharge rates (that is, the quantity of recharge per unit of time) for surface-water basins in the study area. Recharge rates were estimated by using base-flow-discharge measurements (Szilagyi and others, 2003; Risser and others, 2005) and using a recession-curve displacement method (Rutledge, 1998; Rorabaugh, 1964). The recession-curve displacement method provides estimates of recharge through multiple years for the period of record of streamflow analyzed, whereas the base-flow-discharge measurements provide an estimate of recharge each year that the stream was measured. In addition, recharge was calculated for the study area using the SoilWater Balance code (Westenbroek and others, 2010) that uses climate data with soil and land-use data to provide a spatial distribution of recharge.

\section{Recharge from Base-Flow Discharge}

Recharge estimated from base-flow-discharge measurements requires a number of simplifications and assumptions that likely are not met under actual conditions, but base-flowdischarge measurements provide a simple estimate of recharge accurate to an order of magnitude of actual amounts (Rutledge, 1998; Rorabaugh, 1964). Calculation of recharge from base-flow measurements assumes that an aquifer is in steadystate condition, for which discharge is equal to recharge. Base flow was measured during January 2009 at nine of the original sites used for the 1987-89 base-flow measurements reported in Parkhurst and others (1996; table 8). Six additional stream sites were selected for measuring streamflow during baseflow conditions for the investigation described in this report. Recharge rates were calculated from the base-flow measurements by dividing the discharge by the area of the drainage basin, which assumes that the area contributing groundwater to the stream is equal to the area of the drainage basin, and that all areas in the drainage basin are recharged at the same rate. Table 8 shows measured discharge at those streamflow sites and calculated recharge for the upstream drainage basins for each measurement date.

Streams ideal for recharge-estimation measurements are streams that contain drainage basins completely in the aquifer, are not regulated, and do not have withdrawals of surface water, discharges from sewage-treatment plants, or substantial groundwater withdrawals in the drainage basin. The larger streams within the boundaries of the Central Oklahoma aquifer flow through a highly urbanized area. Therefore, most of these streams are regulated or have discharges or withdrawals, so they were not used for the recharge analysis. Recharge rates estimated from the 1987-89 streamflow measurements ranged from 0.19 inches per year at the Pond Creek near 
Eason, Okla., streamflow-gaging station to 3.17 inches per year at the Buckhead Creek near Lexington, Okla., streamflow-gaging station. Recharge rates calculated for the 2009 measurements ranged from 0.20 inches per year at the Deer Creek near Newalla, Okla., streamflow-gaging station to 2.02 inches per year at the Wildhorse Creek at Luther, Okla., streamflow-gaging station. Recharge rates calculated from the streamflow measurements in 2009 are similar to recharge rates calculated from the 1987-89 streamflow measurements (table $8)$. The streams listed in table 8 have basins completely in the aquifer, were not regulated for the period analyzed, and do not have substantial withdrawals and discharges in the streams or aquifer during the period analyzed.

\section{Recharge from Rorabaugh Method}

Another method used to estimate basin-scale recharge for this investigation was a recession-curve displacement method, developed by Rorabaugh (1964). As stated by Rutledge

(1998), the Rorabaugh method is based on the measurement of the change in the total potential groundwater discharge as estimated at the critical time after a discharge peak by extrapolation from the pre-peak and the post-peak recession periods. The Rorabaugh method produces a recharge rate expressed as inches per year for the subsurface drainage basin, which is often assumed to be the surface-water drainage basin area. After analysis of the potentiometric-surface maps in the study area, the groundwater-drainage basin areas appeared to be different sizes than the surface water drainage basin areas (fig. 30). Therefore, the groundwater drainage basin areas were used in the Rorabaugh method for this investigation. The groundwater drainage basin areas were derived by using the 2009 potentiometric-surface contours and assuming that little to no areal recharge enters the aquifer where the Hennessey Group confining unit overlies the aquifer. A series of computer programs by Rutledge (1998) were used to analyze daily stream-discharge data for three streamflow-gaging stations on the Central Oklahoma aquifer. The Deep Fork near Arcadia, Okla., (07242350) (fig. 31), Little River near Tecumseh, Okla., (07230500) (fig. 32), and Deep Fork at Warwick, Okla., (07242380) streamflow-gaging stations discharge data were analyzed using the Rorabaugh method to determine annual recharge rates for the groundwater drainage basins upstream from each streamgage.

Streamflow data were collected at the Deep Fork near Arcadia, Okla., streamflow-gaging station for an unregulated period before the construction of Arcadia Lake Dam. Therefore, estimates of recharge were determined for the period 1969 to 1983, resulting in an average annual recharge rate of 4.1 inches per year (fig. 31). The groundwater drainage basin area above the Deep Fork near Arcadia, Okla., streamflowgaging station is estimated to be 122 square miles (fig. 30). Monthly precipitation data were retrieved from the National Climatic Data Center website (National Climatic Data Center, 2010) for the nearest COOP station, Guthrie 5 S (station number 3821) and the average for each quarter for comparison to the Deep Fork quarterly recharge. COOP stations are further described in the Climate section of this report. The stations used for the recharge analysis were not the same stations used for the climate summary because of the variations in periods of record. The average annual recharge rate also was estimated from the Deep Fork at Warwick, Okla., streamflow-gaging station data to be 3.5 inches per year, but was estimated for just a few years (1984 and 1985) for the unregulated period before construction of the Arcadia Lake Dam. The groundwater drainage basin area above the Deep Fork at Warwick, Okla., streamflow-gaging station was estimated to be 562 square miles. Streamflow data were collected at the Little River near Tecumseh, Okla., streamflow-gaging station with data from 1943 to 1961 being suitable for recharge analysis, producing an average annual recharge rate of 1.3 inches per year (fig. 32). The groundwater drainage basin area above the Little River near Tecumseh, Okla., streamflow-gaging station is 428 square miles (fig. 30). Monthly precipitation data also were retrieved for the nearest COOP station, Meeker (station number 5779) (not shown on figures, outside of map extents) and the average for each quarter for comparison to the Little River quarterly recharge.

Recharge rates calculated using the Rorabaugh method varied from 1.3 inches per year for the Little River near Tecumseh, Okla., streamflow-gaging station to 4.1 inches per year for the Deep Fork near Arcadia, Okla., streamflow-gaging station. A possible reason for this variation could be from different amounts of precipitation, but precipitation is similar for the periods analyzed for each station (figs. 31 and 32). Other reasons for the difference in recharge could be (1) errors in determining the size of the groundwater basin, and (2) differences in runoff between the two watersheds, likely caused by factors such as differences in paved area, slope, and clay content of the soil. The Deep Fork near Arcadia, Okla., and Deep Fork at Warwick, Okla., groundwater drainage basins extend south of the surface-water drainage basins and include recharge from the potentiometric high located near $35^{\circ} 23^{\prime}$ latitude and $97^{\circ} 23^{\prime}$ longitude and from part of the North Canadian River alluvium and terrace deposits (figs. 4 and 30). The recharge values calculated from the Rorabaugh method compare favorably with results from the previous investigation by Parkhurst and others (1996) that describe groundwater flowing under nearby streams to discharge primarily to the Deep Fork River. In addition, the Little River near Tecumseh, Okla., groundwater-drainage basin is located in a part of the aquifer that contains a lesser percent sand and lesser thickness than the part of the aquifer where the Deep Fork near Arcadia, Okla., and Deep Fork near Warwick, Okla., groundwater-drainage basins are located (further described in the Hydrogeologic Framework section of this report). The lesser percent sand and thickness of the aquifer in the Little River near Tecumseh, Okla., groundwater basin might have a smaller hydraulic conductivity and transmissivity and impede precipitation recharge to the aquifer in that area. 


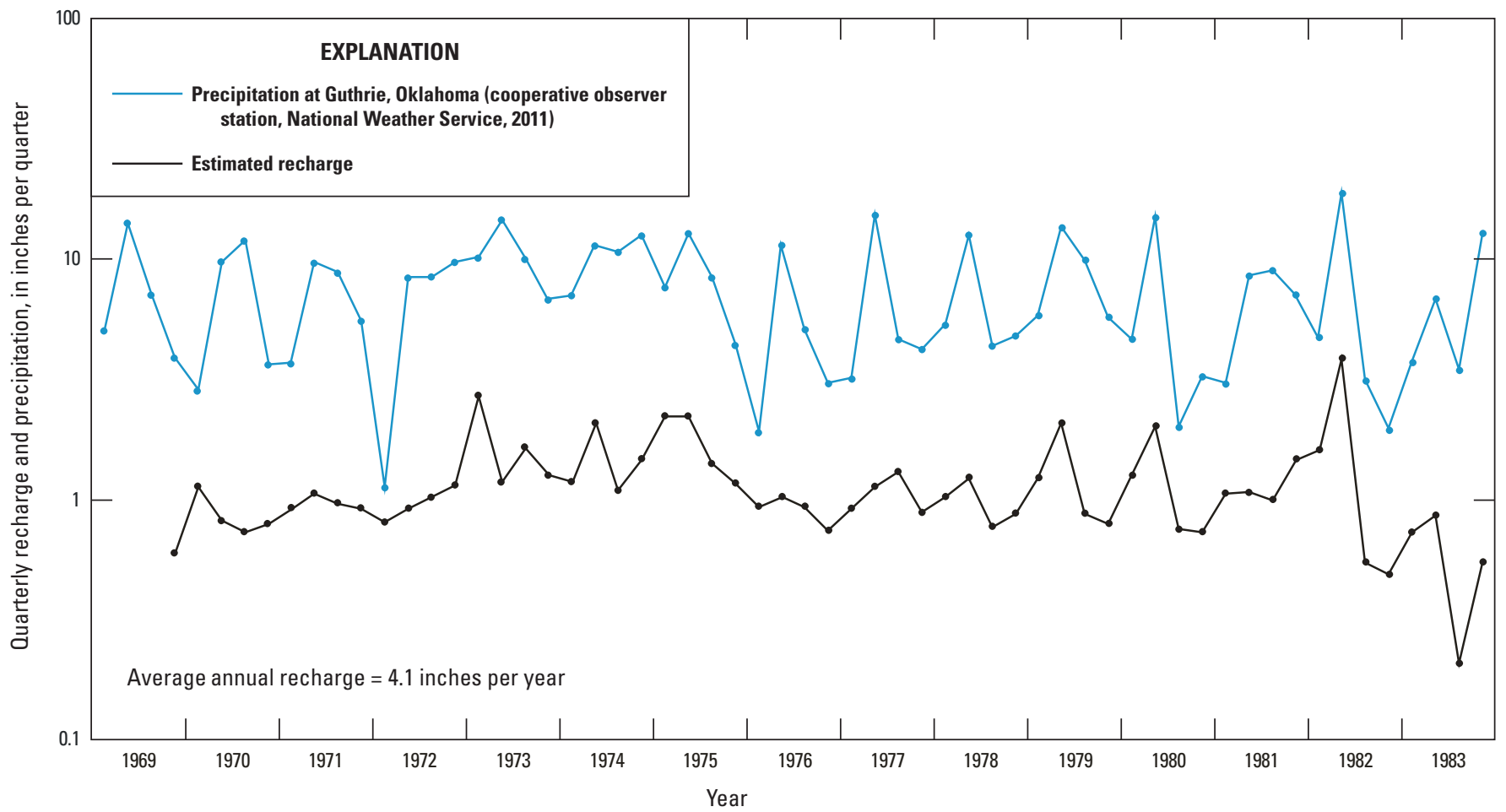

Figure 31. Graph showing estimated quarterly recharge rates and average annual recharge rate using the Rorabaugh method for the Deep Fork River near Arcadia, Oklahoma basin for the period 1969 to 1983.

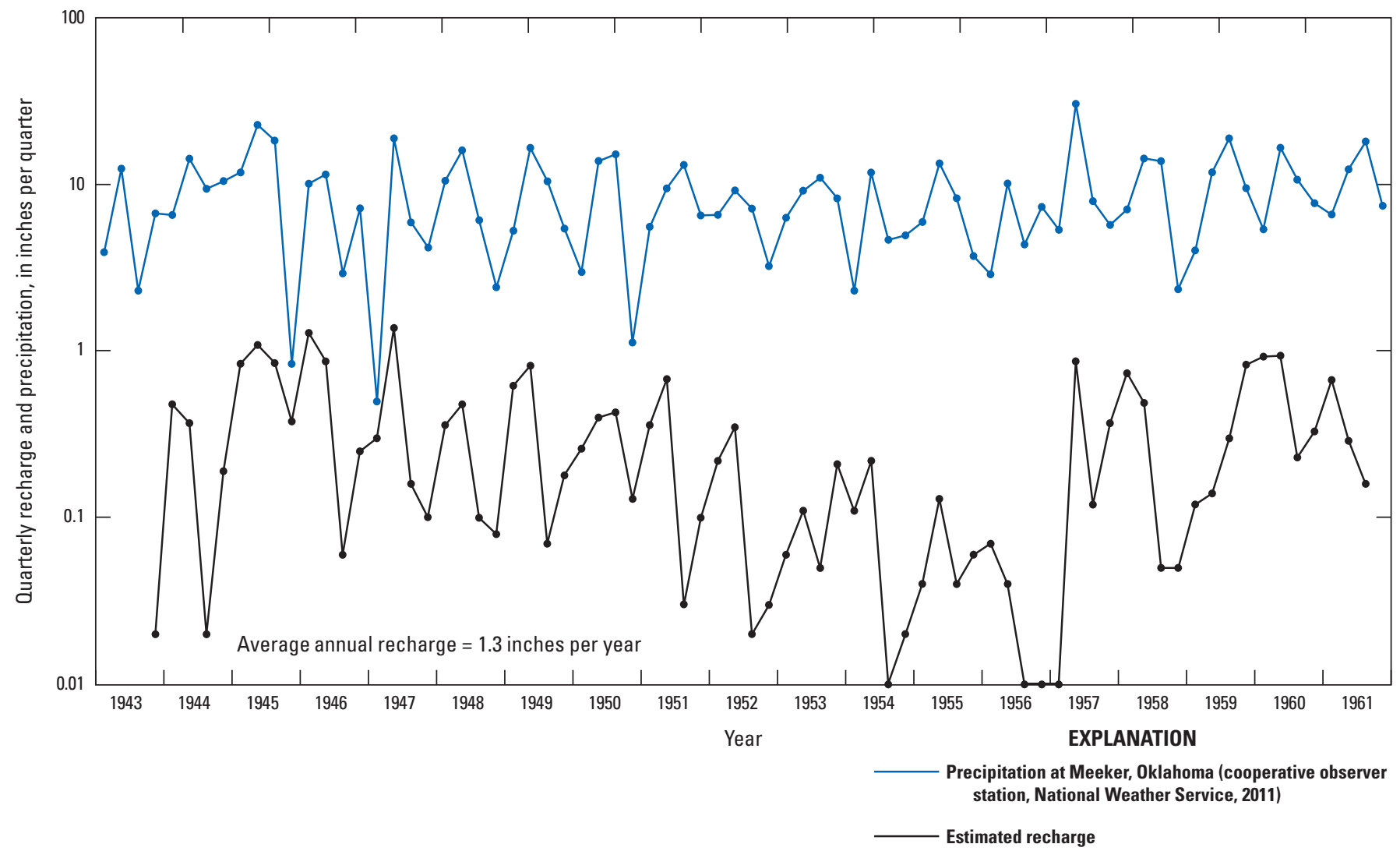

Figure 32. Graph showing estimated quarterly recharge rates and average annual recharge rate using the Rorabaugh method for the Little River near Tecumseh, Oklahoma basin for the period 1943 to 1961. 


\section{Recharge Calculated Using the Soil-Water Balance Code}

The Soil-Water Balance (SWB) code (Westenbroek and others, 2010) uses climate data with soil and land-use data to estimate spatial distribution of recharge. Recharge was estimated on a regional scale using the SWB code developed by Westenbroek and others (2010). The SWB code calculates potential recharge as water that is surplus in the soil profile, which is the amount of precipitation infiltration that exceeds the storage capacity of the soil in the root zone and the demand from plants for evapotranspiration (ET). ET is calculated using the Hargreaves-Samani method (Hargreaves and Samani, 1985) using latitude and daily high and low temperatures. Soil properties also are used to estimate how much of the daily precipitation enters the soil profile and how much of the daily precipitation runs off. Land-cover properties (MultiResolution Land Characteristics Consortium, 2001) are used in the SWB to specify interception by plants and runoff curve numbers. SWB analysis increased soil moisture during growing seasons for cells that were coded as irrigated agriculture in the land-use data set to simulate the effects of irrigation. The analysis did not route irrigation runoff or track deep percolation from inefficient irrigation application methods.

Soil properties were derived from the General Soil Map (STATSGO2; Natural Resources Conservation Service, 2006). Digital-elevation models were analyzed to determine the surface-water-flow direction for each grid cell, as described in Westenbroek and others (2010). These physical grids were assumed to remain constant during the model time period. The grid-cell size used for the SWB code was 3,280 by 3,280 feet ( $1 \mathrm{~km}$ by $1 \mathrm{~km})$. Daily climate data included grids of precipitation, high temperature, and low temperature. Precipitation and temperature data were interpolated across the study area from National Weather Service weather stations (National Climatic Data Center, 2010), and after 1994 data from the Oklahoma Mesonet weather network (Oklahoma Climatological Survey, 2011c) were included (fig. 1).

Results of the SWB model analysis were total annual recharge grids that were time-averaged to average daily values at each grid cell for use in the groundwater-flow model (fig. 33). Average annual recharge for the gridded aquifer area for 1987 was 3.4 inches per year. Average annual recharge for the gridded aquifer area for the 1987-2009 period was 4.6 inches, which was similar to the recharge rate calculated for the Deep Fork River using the Rorabaugh method. The minimum average annual recharge for the gridded aquifer area for the 1987-2009 period was 1.9 inches per year in 2006. The maximum average annual recharge for the gridded aquifer area for the 1987-2009 period was 8.5 inches per year during the year 2007. However, during model calibration (see Calibration Process sections) a scaling factor of 0.4 was applied to SWB recharge, which resulted in minimum and maximum values of 0.76 inches per year in 2006 and 3.4 inches per year in 2007, respectively. Average annual recharge values for the gridded aquifer area for the 1987-2009 period with a scaling factor of
0.4 applied, was 1.84 inches per year. Maximum values were calculated at focused recharge locations where surface water is concentrated by runoff to areas of lower altitudes.

Because SWB estimates deep percolation that may or may not contribute to the groundwater system, this model can overestimate recharge. Another limitation of the SWB code is that does not consider plant uptake from groundwater where the water table could be in the root zone for part or all of the year. The spatial distribution of recharge provided by SWB has, however, been shown to be an effective starting point for groundwater-flow model calibration (Stanton and others, 2012).

\section{Aquifer Hydraulic Properties}

Hydraulic properties refer to characteristics that affect groundwater flow through and storage of water in an aquifer. For this study, the principle hydraulic properties used to describe the Central Oklahoma aquifer were hydraulic conductivity, vertical anisotropy, transmissivity, and confined and unconfined storage coefficients. Hydraulic conductivity of the aquifer under isotropic conditions is defined as "the volume of water at the existing kinematic viscosity that will move in unit time under a unit hydraulic gradient through a unit area..." (Lohman, 1972). Hydraulic conductivity is expressed in units of length per time (feet per day in this report). Transmissivity is the rate that water is "transmitted through a unit width of the aquifer under a unit hydraulic gradient" (Lohman, 1972). Transmissivity is expressed in terms of length squared per time (square feet per day in this report).

A storage coefficient is the volume of water an aquifer releases from or takes into storage per unit surface area of the aquifer per unit change in head (Lohman, 1972), and is dimensionless. Storage of water in the Central Oklahoma aquifer is released under confined (storage coefficient) and unconfined (specific yield) conditions. Storage in confined aquifers is affected by additional stresses caused by the overburden of overlying rock and water. Water is released from storage in confined aquifers caused by the compressibility of the water and the aquifer matrix. Although the water is released from storage, the aquifer remains saturated. Water is released from storage in an unconfined aquifer as water drains from pore spaces, which is defined as specific yield.

The most difficult hydraulic property of the Central Oklahoma aquifer to quantify is anisotropy, which is the ratio of horizontal hydraulic conductivity to vertical hydraulic conductivity. Anisotropy has not been directly measured or estimated in the Central Oklahoma aquifer and that characterization was beyond the scope of this investigation. Estimations and assumptions used to characterize the vertical flow of water through the Central Oklahoma aquifer are described in the Groundwater-Flow Model Hydraulic Properties section of this report.

Aquifer hydraulic properties were compiled from previous publications about the aquifer, estimated from lithologic 


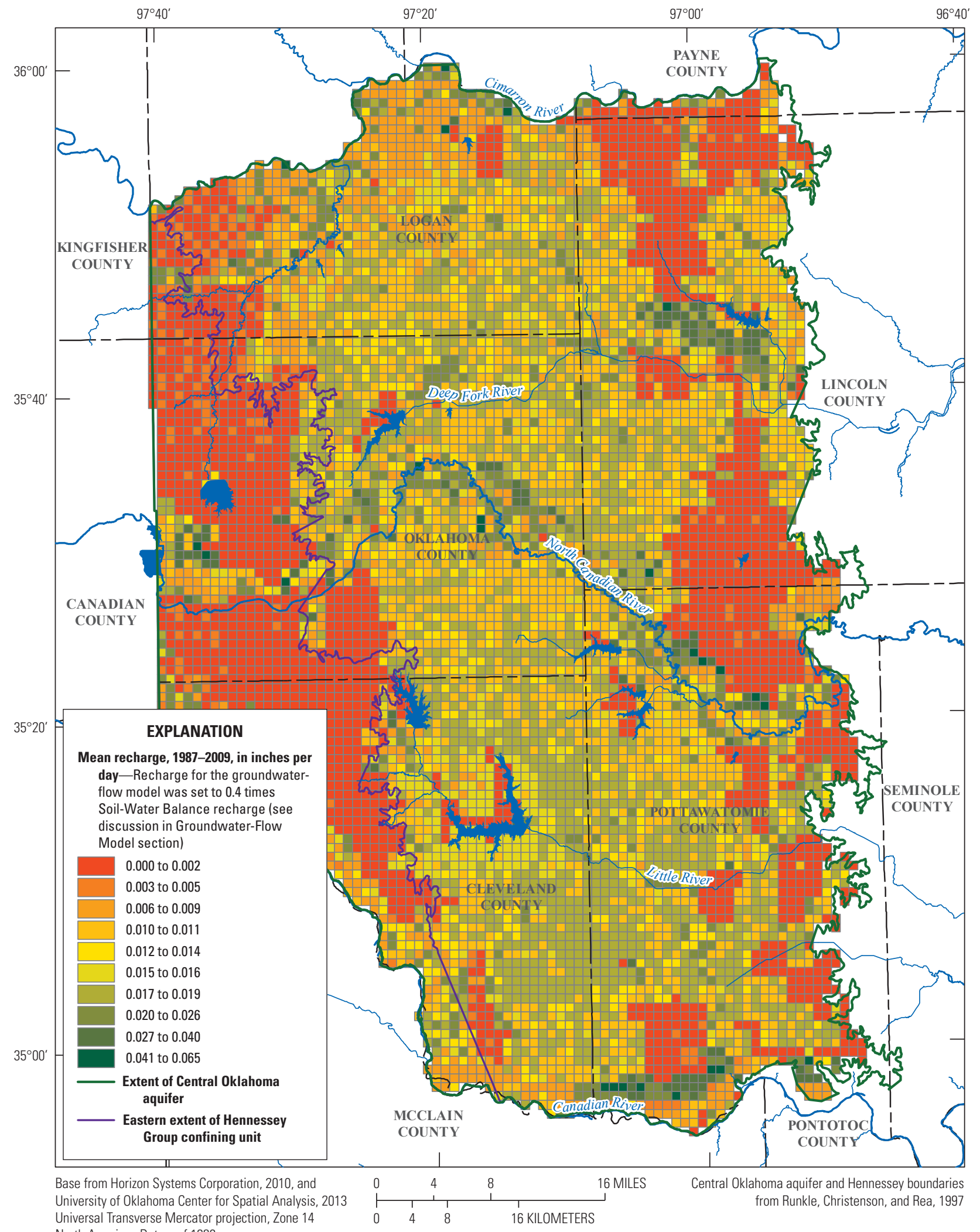

North American Datum of 1983

Figure 33. Average annual recharge calculated using the Soil-Water-Balance code (Westenbroek and others, 2010) for the Central Oklahoma aquifer for the period 1987-2009 in 3,280-ft by 3,280-ft grid cells. 
and geophysical well logs, and calculated from a multiplewell aquifer test. Parkhurst and others (1996) reported geohydrologic-unit hydraulic conductivity for wells deeper than 500 feet in this aquifer of 0.30 to 7.1 feet per day, with a median of 1.5 feet per day. Gates and others (1983) compiled hydraulic data from existing aquifer tests and conducted additional aquifer tests as part of their study. Transmissivity values in their report ranged from 20 to 900 square feet per day, with a median of 400 square feet per day. Storage coefficient values were determined for several of the aquifer tests and ranged from 0.0001 to 0.0003 . These small storage coefficients indicate that, even though the Central Oklahoma aquifer extends to land surface with a potentiometric surface below the top of the Central Oklahoma aquifer, the groundwater system acts as a confined system.

Previously published hydraulic conductivities of the Hennessey Group, which acts as an upper confining unit to the Central Oklahoma aquifer, derived from permeameter testing ranged from $1.1 \times 10^{-6}$ to $1.1 \times 10^{-4} \mathrm{ft} / \mathrm{d}$, and derived from slug testing ranged from $8.5 \times 10^{-8}$ to $3.1 \times 10^{-4} \mathrm{ft} / \mathrm{d}$ (Becker and others, 1997). Wood and Burton (1968) completed six aquifer tests in the Central Oklahoma aquifer. Three aquifer tests completed near the University of Oklahoma determined transmissivity to be 400 to 700 square feet per day and that storage coefficients ranged from 0.0001 to 0.0003 (Wood and Burton, 1968). An aquifer test completed in Midwest City, Okla., produced a transmissivity of 700 square feet per day and a storage coefficient of 0.0003 , an aquifer test completed in Edmond, Okla., produced a transmissivity of 900 square feet per day and a storage coefficient of 0.0002 , and an aquifer test completed in Nichols Hills, Okla. (near The Village; fig. 1), produced a transmissivity of 500 square feet per day and a storage coefficient of 0.0001 (Wood and Burton, 1968). Wood and Burton (1968) used the Theis (1935) nonequilibrium formula to analyze the aquifer tests, which assumes the aquifer is unconfined. Storage coefficients determined using the nonequilibrium formula do not account for water derived from low-permeability geologic units (such as the mudstones in the Central Oklahoma aquifer) and are likely to be less accurate for this aquifer but are included here for completeness.

Wood and Burton (1968) suggested that the variability in the thickness of individual sandstone beds over short distances will cause the hydraulic properties and connectivity between wells to vary over short distances. They noted during the aquifer tests in Nichols Hills that water levels in two deep wells located 0.5 mile away from the pumping well decreased by about 10 feet, whereas water levels in three nearby shallow wells fluctuated slightly (less than a foot of change).

\section{Norman Aquifer Test}

A multiple-well aquifer test was completed at a production well near Norman, Okla., (fig. 1) as part of this investigation to determine a transmissivity, hydraulic conductivity, and storage coefficient for the Central Oklahoma aquifer. Details and analyses of this aquifer test are provided in appendix 1 .
Transmissivity determined from the analytical solution was 220 square feet per day. Using the screened interval of 90 feet in the production well, the geohydrologic-unit hydraulic conductivity was 2.4 feet per day. The average percent sand of the Central Oklahoma aquifer at that location was approximately 70 percent (further described in the Hydrogeologic Framework section of this report). The analytical-model solutions indicated a leaky confined aquifer. The storage coefficient from the analytical solution was 0.0013 , which is an order of magnitude higher than previously published storage coefficients for this aquifer (Wood and Burton, 1968; Gates and others, 1983). Storage coefficients reported in previous publications (Wood and Burton, 1968; Gates and others, 1983), using the nonequilibrium formula, do not account for water derived from low-permeability geologic units (such as the mudstones in the Central Oklahoma aquifer) and are likely to be underestimated. The transmissivity, hydraulic conductivity, and storage coefficient derived from the aquifer test done for this investigation are likely to be more accurate than hydraulic values derived using other methods, such as from grain size or laboratory tests of aquifer material. However, these hydraulic values represent local conditions and are not necessarily indicative of the hydraulic property values of larger areas. For example, if an aquifer test was completed in Edmond, Okla., the transmissivity and storage coefficient would likely be different than the test completed in Norman, Okla., and the aquifer at both sites may respond differently to the withdrawal. The hydraulic conductivity at this Norman, Okla., location was expected to be somewhat larger than the hydraulic conductivity measured at a site in the aquifer that contains less sandstone and more mudstone.

\section{Hydrogeologic Framework}

A hydrogeologic framework of the Central Oklahoma aquifer was developed to describe the lithology of the Central Oklahoma aquifer, including sandstones, siltstones, and mudstones. The objective of developing the hydrogeologic framework was to provide a three-dimensional representation of the lithologic variability of aquifer materials at a scale that captured the regional controls on groundwater flow for construction of the groundwater-flow model. The distribution and variability of mudstones interbedded with sandstones and siltstones were considered to be the major control on groundwater flow in the aquifer as there were no known major structural or karst features in the aquifer that might substantially affect groundwater flow.

\section{Percent Sand Data Sources and Standardization Methods}

Lithologic and gamma-ray borehole logs, in conjunction with aquifer-test data, were used to develop the hydrogeologic framework. Lithologic logs and gamma-ray logs 
were converted to percent sand, which was used as a proxy to estimate initial hydraulic conductivity of the aquifer for the groundwater-flow model. An inventory of the available log data showed that neither lithologic nor gamma-ray borehole logs provided complete quality, depth, and geographic coverage of aquifer properties alone. However, a combination of these datasets provided adequate coverage to construct a threedimensional representation of percent sand in the aquifer.

\section{Lithologic Logs}

Available lithologic logs of varying depth, submitted to the OWRB by well drillers included descriptions of cuttings that were recorded as water-well boreholes were drilled. In the State of Oklahoma, there are no specified standards for lithologic descriptions by well drillers, leading to varying descriptions between drilling companies and individual well loggers. The OWRB provided the USGS with copies of lithologic logs for the Central Oklahoma aquifer. These data are stored in the OWRB water-well records database (Oklahoma Water Resources Board, 2013).

Most lithologic logs include, at a minimum, categories for sandstone (often called sandrock) and mudstone (often called mudrock). Many drillers' logs also contain intermediate lithologies, though the names used for these categories vary widely. To simplify and standardize the lithologic logs, the lithologic descriptions were reclassified into four categories that were used to estimate the percent sand of each depth interval. Lithology was categorized into mud, sandy mud, muddy sand, and sand, which can be conceptually simplified and quantified as a continuous series of textures from 0 percent sand (mudstone) to 100 percent sand (sandstone).

To estimate a percent sand from a lithologic log, each lithologic category was assigned a percent sand using a multiplier. For example, the sand category was assigned a bin percent sand range of 100 to 75 percent sand and a midpoint of 87.5 percent sand. The midpoint of each bin was used as a percent-sand multiplier to convert each lithologic category to a numeric value because the multiplier was a mean percent sand for each bin (fig. 34). The sand multiplier was 87.5 percent sand, the muddy sand multiplier was 62.5 percent sand, the sandy mud multiplier was 37.5 percent sand, and the mud multiplier was 12.5 percent sand. The percent sand was summarized into a total percent sand for each lithologic log using a weighted average of the length of the log. The maximum percent sand for any log was 87.5 and the minimum percent sand for any log was 12.5 . These percent-sand ranges were consistent with the 16 to 88 percent sand described by Schlottman and others (1998) for rocks in the Central Oklahoma aquifer. Lithologic logs were categorical and of irregular frequency with depth. Therefore, summarizing percent sand for regular depth intervals (layers) using an automated process was not feasible.

Approximately 11,000 lithologic logs were used for the percent-sand analysis (fig. 35). Limitations of using lithologic logs include errors in spatial location, depth of intervals, and lithologic descriptions. Records with obvious errors were corrected to extract as much useful information as possible, or deleted from the database if the log appeared to be insufficient.

Most of the lithologic logs in the OWRB database were from shallow, domestic wells, which typically only penetrate up to approximately 300 feet below land surface (fig. 36).

Therefore, lithologic logs tend to over-represent the shallow aquifer and under-represent the deep aquifer. Lithologic logs of the Hennessey Group were not included in the percentsand analysis because many of these logs were from wells completed in localized sandstone members in the Hennessey Group most likely not connected to the Central Oklahoma aquifer.

\section{Gamma-Ray Logs}

Radioactive elements occur naturally in depositional particles in sedimentary rocks. Finer particles (mudstones, claystones, shales) contain higher concentrations of radioactive elements. Larger particles (sandstones, sands, gravels) contain more silica and generally emit very low levels of radiation. Gamma-ray borehole logs are useful for differentiating fine-grained rocks (mudstones) that are less permeable than coarse-grained rocks (sandstones). For the Central Oklahoma aquifer, gamma-ray logs are useful for detecting changes in lithology and identifying potentially water-yielding rocks. Gamma-ray logs record by depth the total natural gamma-ray radiation emitted by rocks, specifically from the elements potassium, thorium, and uranium, which are present in larger amounts in mudstones and shales than in sandstones (Keys, 1990). Gamma-ray logs used in the investigation described in this report recorded intensity of gamma-ray radiation in three different units: (1) American Petroleum Institute (API) units, (2) counts per second, or (3) microRoentgens per hour. The gamma-ray logs were obtained from numerous companies, Frontier Logging Corporation, and Association of Central Oklahoma Governments.

\begin{tabular}{|c|c|c|c|}
\hline \multicolumn{4}{|c|}{ Percent sand } \\
\hline 0 & 25 & 50 & 75 \\
\hline Sand & Muddy sand & Sandy mud & Mud \\
\hline 1 & 1 & 1 & $T$ \\
\hline 87.5 & 62.5 & 37.5 & 12.5 \\
\hline
\end{tabular}

Figure 34. Lithologic category bins for converting lithologic logs into percent sand. 


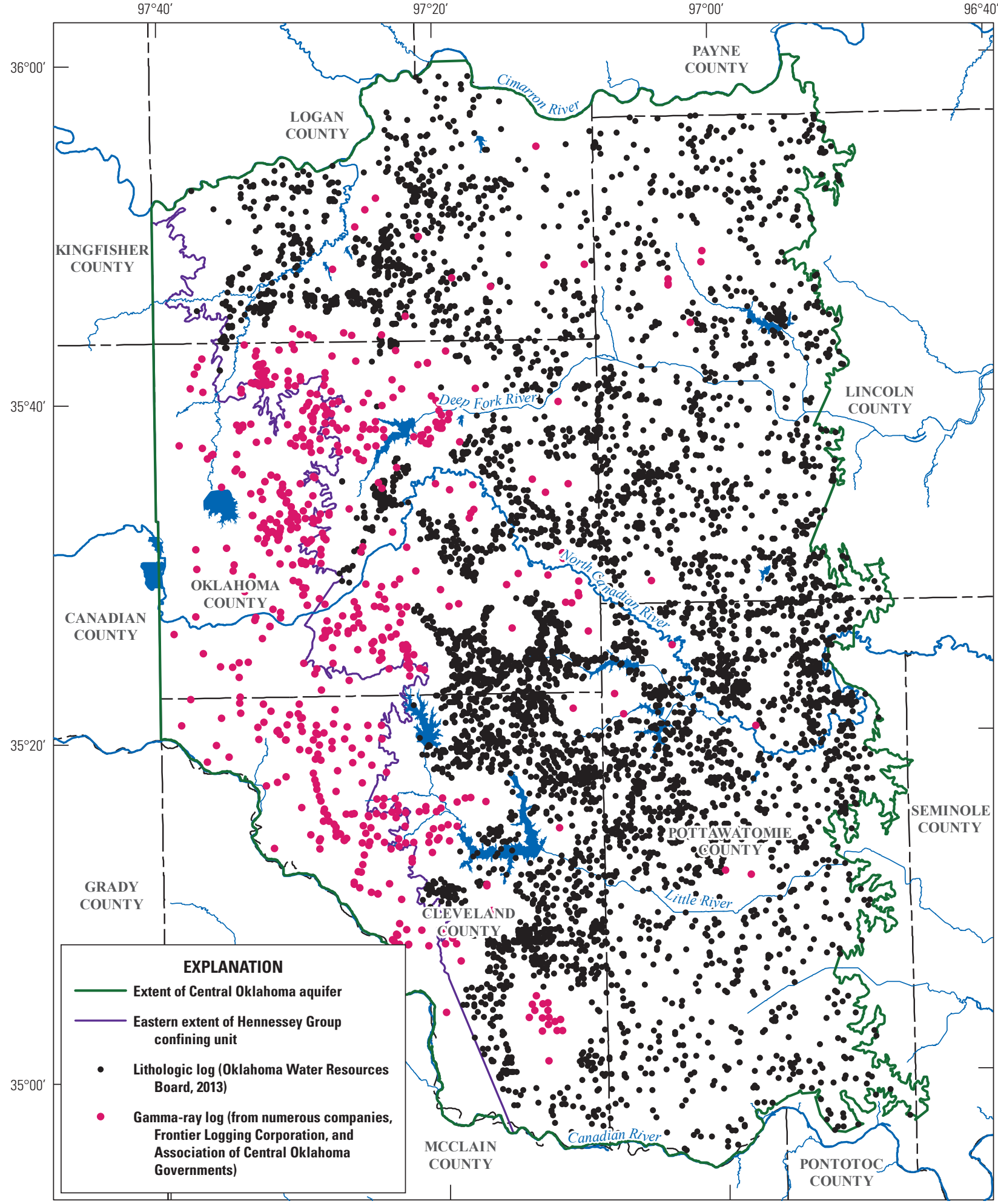

Base from Horizon Systems Corporation, 2010, and University of Oklahoma Center for Spatial Analysis, 2013 Universal Transverse Mercator projection, Zone 14

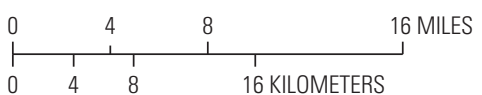

Central Oklahoma aquifer and Hennessey boundaries North American Datum of 1983

Figure 35. Locations of lithologic logs and gamma-ray logs used for hydrogeologic framework percent-sand analysis of the Central Oklahoma aquifer. 

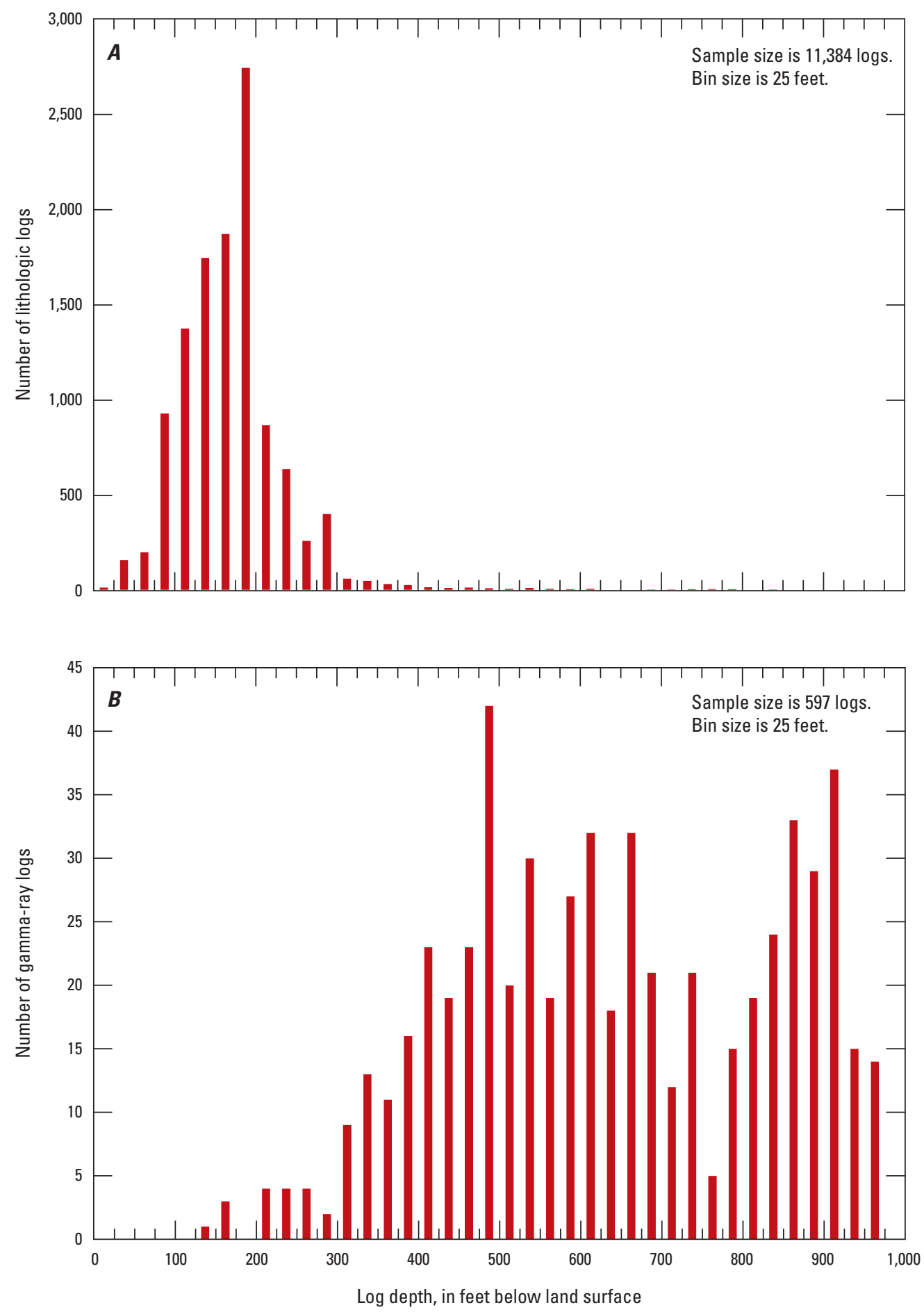

Figure 36. Distribution of depths of $A$ ) lithologic logs and $B$ ) gamma-ray logs used for hydrogeologic framework percent-sand analysis in the Central Oklahoma aquifer. 
The approach used to classify percent sand from the gamma-ray data assumed that each gamma-ray log included at least one sand ( 87.5 percent sand) and at least one mud (12.5 percent sand). A sand was determined to correspond to the minimum intensity and a mud was determined to correspond to the maximum intensity on the gamma-ray log. A sand, or minimum intensity gamma-ray, was assigned a value of 87.5 percent sand and a pure mud, or maximum intensity gamma-ray, was assigned a value of 12.5 percent sand. All gamma-ray values between the minimum and maximum were scaled relative to the position of the value between the 12.5 and 87.5 percent sand (fig. 37). This scaling technique was independent of the units of measure and normalized the gamma-ray logs to make them more comparable. The multipliers for each bin were the same as the multipliers used in the lithologic-log conversion (fig. 34).

Selection of the pure mudstone, or maximum gammaray value, was complicated by the presence of spikes in gamma-ray intensity. Spikes are anomalously high gammaray intensities that can be three to four times the gamma-ray intensity of normal mud. Zones of gamma-ray spikes are usually no more than a few feet in thickness, and occur locally, most notably near Nichols Hills, Okla. (near The Village; fig. 1), The cause of such spikes is unknown, but they could be related to increased concentrations of uranium and thorium, which emit gamma-ray radiation and can cause anomalously high readings. Increased gamma-ray intensities were documented in some core samples (Schlottmann and others, 1998) and described on page IV-8 in Gates and others (1983). The method used for this report to determine the mudstone/sandstone content would underestimate percent sand if spikes were included in the analysis for percent sand. Therefore, gamma-ray logs were screened for spikes using an automated objective process and a visual subjective process. The method of using the minimum and maximum gamma ray as indicators of percent sand for each log makes the method sensitive to the presence of spikes, so when identified, spikes were not included in the percent-sand analysis.

In areas where the gamma-ray logs contain the overlying Hennessey Group, the base of Hennessey Group structural contour map (fig. 6) was used for initial guidance as to where to omit the gamma-ray data for the Hennessey Group from the analysis. After this screening process, additional examination of the gamma-ray logs indicated in some cases, gamma-ray values near the top of the logs were much higher than the gamma-ray values for the Central Oklahoma aquifer. This anomaly was an indication that the structural contour map did not always portray the exact vertical location of the Hennessey Group, and the gamma-ray signatures provided a more detailed estimate of the depth to base of Hennessey Group. The base of freshwater-elevation contours were used to determine the base of the aquifer to remove the logs that penetrated below the base of the aquifer from the analysis (fig. 11).

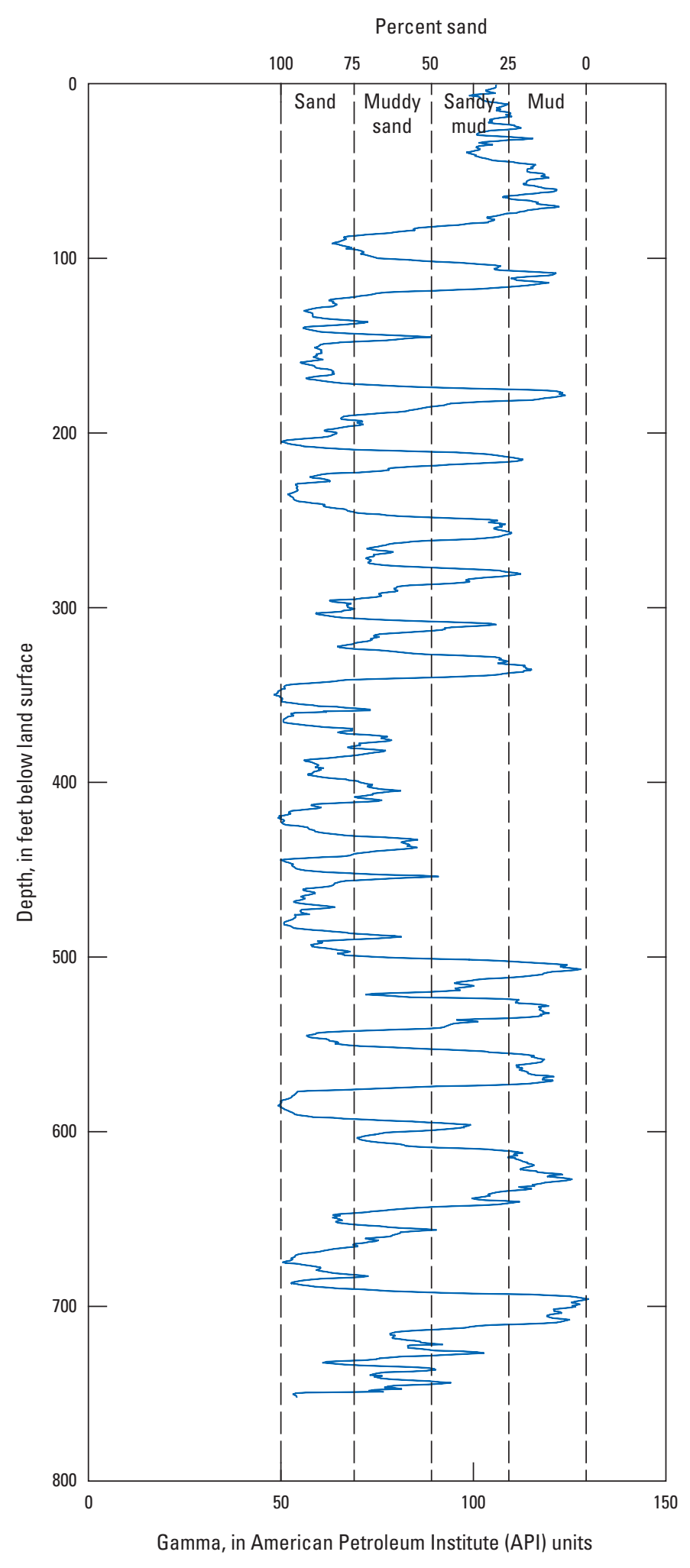

Figure 37. Scaling technique used to convert a gamma-ray log into percent sand for hydrogeologic framework percent-sand analysis in the Central Oklahoma aquifer. 
Approximately 600 gamma-ray logs were used for the percent-sand analysis (fig. 35). Most of the gamma-ray logs used for the analysis were from water-production wells, and some oil and gas wells. Depths of the logs ranged from approximately 300 to 1,000 feet below land surface (fig. 36). The spatial coverage of the gamma-ray logs was denser in the western part of the aquifer where more water-production wells are located and sparser in the eastern part of the aquifer where more domestic wells have been drilled (fig. 35).

For this investigation, gamma-ray log signatures on paper were scanned and digitized, sampling every 0.5 -foot using Neuralog software (Neuralog, Inc., 2010). The digitized logs were saved as text files in Log ASCII Standard format and as Microsoft Excel spreadsheets; gamma-ray log sites were established in the USGS NWIS database.

Gamma-ray log data were stored at 0.5 -foot depth intervals and for consistency were summarized in the same manner as the lithologic-log data, with the same 4 bins of percent sand categories and the same maximum ( 87.5 percent) and minimum percent sand (12.5 percent) (fig. 37). All data points were assigned one of four multipliers corresponding to the midpoint of each bin (fig. 34). Next, these multipliers were summarized for each log by using a weighted average of the interval thickness.

\section{Spatial Distribution of Percent Sand}

Using gamma-ray logs to determine percent sand produced a dataset that could be summarized into percent sand for any defined depth interval. Lithologic logs were used to determine percent sand and produced a dataset of total percent sand for each log. To spatially distribute the percent sand for the hydrogeologic framework, the data points of lithologic log percent sand and gamma-ray log percent sand were incorporated into GIS. For spatial interpolations at different depth intervals, each lithologic log was represented by a single percent sand value. However, for gamma-ray logs, multiple percent sand values at 0.5 -ft intervals were averaged for each interval thickness to be interpolated.

To distribute percent sand between wells, an inverse distance-weighted interpolation method was used. Inverse distance-weighted interpolation estimates percent sand for any location without logs by using logs surrounding that location, giving higher weight to logs closest to that location (Esri, 2007). Inverse distance-weighted interpolation assumes that logs closest to the location without logs are more similar to the unknown logs than logs farther away.

Percent sand was interpolated for individual layers to build the hydrogeologic framework. The hydrogeologic framework grid was $3,280 \mathrm{ft}$ by $3,280 \mathrm{ft}(1 \mathrm{~km}$ by $1 \mathrm{~km})$. Layers were horizontal and 100-ft thick (fig. 38). The top of the hydrogeologic framework was either the base of the Hennessey Group, where present (fig. 6), or the land surface. The bottom of the hydrogeologic framework was either the base of freshwater (figs. 5 and 11) (equivalent to $5,000 \mathrm{mg} / \mathrm{L}$ dissolved solids) or the base of the Chase, Council Grove, and Admire Groups (figs. 5 and 8). The base of the deepest layer was $200 \mathrm{ft}$ altitude above North American Vertical Datum 1988 (NAVD 88). Each subsequent layer was $100 \mathrm{ft}[30.48$ meters (m)] higher. This approach produced 11 layers for the percentsand interpolation. The inverse distance-weighted method was used to interpolate between data points for each layer using a power of 3 and the maximum number of points was 300. The gamma-ray percent sand and the lithologic-log percent sand were used to interpolate percent sand between log locations, however, preference was given to gamma-ray-derived percent sand because gamma-ray logs were more detailed with depth. Therefore, lithologic-log locations that were within $9,843 \mathrm{ft}$ (3 km) of a gamma-ray log location were omitted from the interpolation by using a buffer zone around the lithologic logs. The gamma-ray and lithologic logs located beyond $9,843 \mathrm{ft}$ $(3 \mathrm{~km})$ from a gamma-ray log location were used in the inverse distance-weighted interpolation. The length of $9,843 \mathrm{ft}$ $(3 \mathrm{~km})$ was chosen because any length less than $3 \mathrm{~km}$ resulted in predominant use of drillers' logs in the interpolation.

\section{Hydrogeologic Framework Results}

The hydrogeologic framework produced a unique distribution of percent-sand values for each of the 11 horizontal layers (figs. 38 and 39). Percent-sand values for the horizontal layers were designated to be between 12.5 and 87.5 percent to remain consistent with previously published percent-sand values of 16 to 88 for rocks in the Central Oklahoma aquifer. Percent sand interpolated for the 4 deepest layers ( 8 through 11) was determined from gamma-ray log data only. Percentsand values interpolated in layers 5 through 7 were determined from a combination of lithologic and gamma-ray log data. Percent sand interpolated for the shallowest layers (1 through 4) were determined from lithologic log data only.

The median percent sand derived from gamma-ray logs was approximately 63 , whereas the median percent sand from lithologic logs was approximately 53 (fig. 40). The range of percent sand from lithologic logs is higher than the range of percent sand from the gamma-ray logs (fig. 40). The differences in percent sand from the two data sources could be a result of the difference in sampling locations; the gamma-ray logs mostly capture the deeper zones of the western part of the aquifer, which contain thicker sections and larger percents of sandstone (Schlottman and others, 1998), but most lithologic logs used in this analysis are located in the eastern part of the aquifer (fig. 35), which contain thinner sections and lower percents of sandstone (Schlottman and others, 1998). Another possible cause of the difference in percent-sand estimates is that the two methods were fundamentally different. 


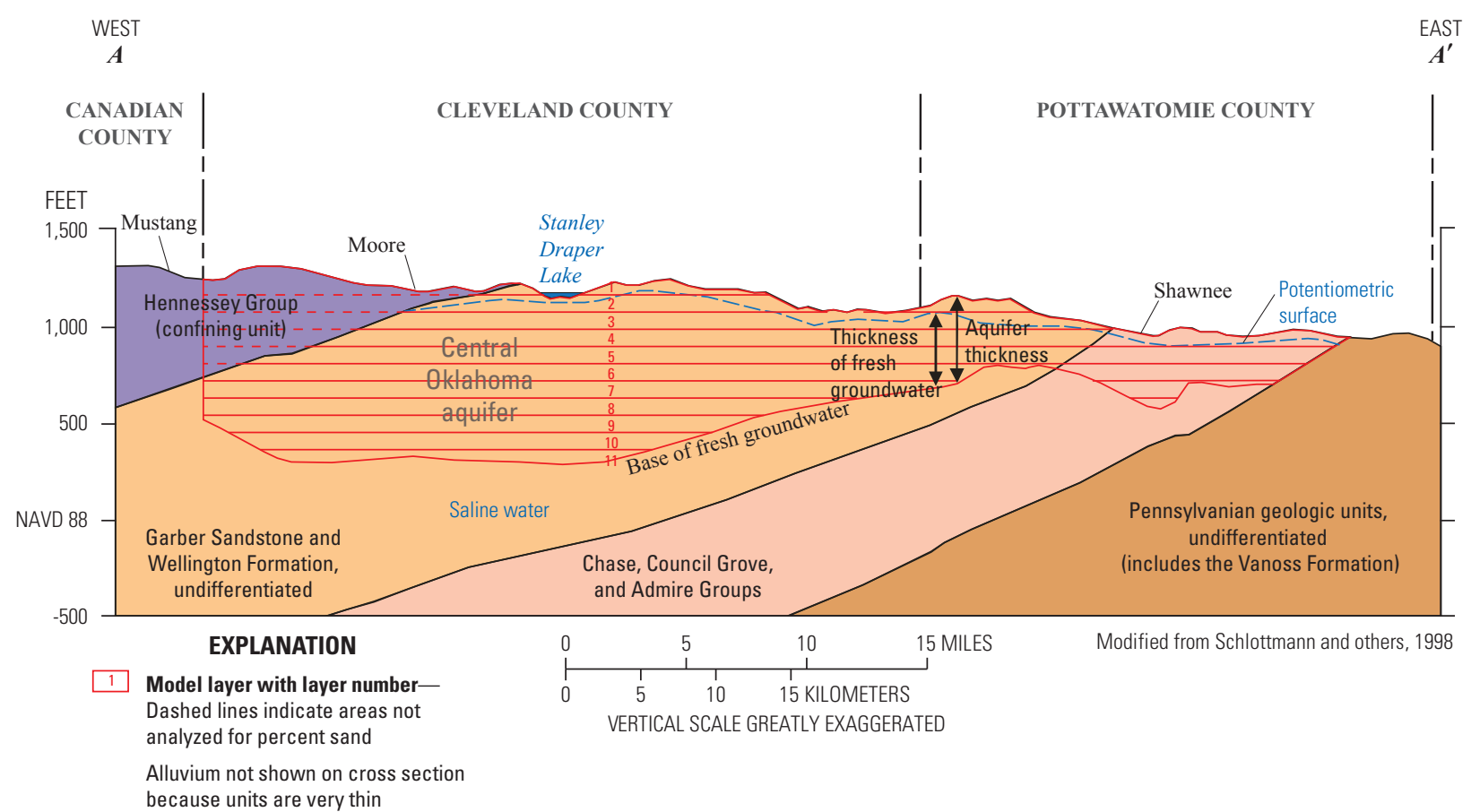

Figure 38. Cross-section $A-A^{\prime}$ diagram (shown on figure 4) showing layers for which percent sand was interpolated in the hydrogeologic framework of the Central Oklahoma aquifer.

\section{Groundwater-Flow Model}

A numerical groundwater-flow model was constructed for the Central Oklahoma aquifer to simulate groundwater flow, build water budgets under various stresses, and to describe how groundwater storage may change under these stresses. The groundwater-flow model was calibrated using water-level observations and was subsequently used to evaluate various pumping scenarios projected to the year 2059 to evaluate the effects of pumping on the amount of water in storage in the Central Oklahoma aquifer.

\section{Conceptual Flow Model}

A conceptual flow model is a narrative and schematic description of a groundwater-flow system, and an important component of constructing a numerical groundwater-flow model. The conceptual flow model describes how the groundwater-flow system is thought to function, and thus contains the framework and components that control the storage and flow of groundwater. The two key components of the conceptual flow model include the hydrologic boundaries and the water budget. The hydrologic system boundaries are parts of the flow system that interact with groundwater, providing a condition in which water enters or leaves the system. The water budget describes how much of the water in the flow system is accounted for by each of the boundaries.
Hydrologic boundaries are important for achieving a unique solution to a simulation, and include internal and exterior types (Reilly, 2001). Internal hydrologic boundaries include wells, streams (streams also can be external if no appreciable flow moves under the stream), and lakes inside the model domain. Hydrologic boundaries at the lateral or vertical extents are exterior boundaries and can include confining units, faults, or lithofacies changes. The discretization of time that the model uses also is a boundary, but this boundary is described in the Numerical Groundwater-Flow Model Construction Simulation Periods section.

External boundaries of the Central Oklahoma aquifer used in this model included: (1) zero-flow boundaries where the aquifer is absent or no substantial flow is assumed to cross that boundary, and (2) streams that interact with the aquifer. The east external boundary is considered to be zero-flow, as the Central Oklahoma aquifer becomes thin moving up-dip of the geologic units and is removed by erosion at the surface. The western boundary also is assumed to have zero flow as the part of the aquifer saturated with freshwater intersects the Hennessey Group confining unit. The northern boundary of the Central Oklahoma aquifer is assumed to be the Cimarron River, and the southern boundary is assumed to be the Canadian River. These rivers flow from west to east through areas where the freshwater zone of the aquifer is relatively thin and previous studies of the potentiometric surface indicate that little or no flow passes beneath the streams in either direction 
(figs. 10 and 12) (Christenson and others, 1992; Mashburn and Magers, 2011).

The lower external boundary of the Central Oklahoma aquifer is defined as either (1) the contact between the Chase, Council Grove, and Admire Groups (undifferentiated), a confining unit, and the Vanoss Formation (figs. 8 and 38) or (2) the depth of the base of freshwater (groundwater that contains less than $5,000 \mathrm{mg} / \mathrm{L}$ dissolved solids) (figs. 11 and 38). On the eastern part of the model area, the lower boundary is defined as the contact with the Chase, Council Grove, and Admire Groups (undifferentiated), a confining unit (fig. 38). The map of the base of fresh groundwater shows the freshwater/saline interface intersecting the base of the Hennessey Group in the western part of the Central Oklahoma aquifer near the Oklahoma-Canadian/Kingfisher-Logan County line, which indicates that circulation of freshwater does not extend beyond this intersection (fig. 11). In addition, Hart (1966) also indicates a sharp increase from about 200 to $800 \mathrm{ft}$ in elevation of the base of fresh groundwater near the Oklahoma-Canadian/Kingfisher-Logan County line. Therefore, the western extent of the Central Oklahoma aquifer was established at the freshwater/saline interface near the Oklahoma-Canadian/ Kingfisher-Logan County line. The potentiometric-surface map in Mashburn and Magers (2011) indicates that freshwater is present in the alluvium and Hennessey Group, but circulation of this freshwater in the Hennessey Group is assumed to be minimal because of low transmissivities.

The Central Oklahoma aquifer is believed to have a high vertical anisotropy ratio causing limited circulation and flow in deep parts of the aquifer (near the freshwater/saline interface). The recharge age of water sampled from deep wells in the Central Oklahoma aquifer has been found to be old, as much as 30,000 years (Parkhurst and others, 1996), indicating that under natural and stressed conditions, little to no mixing with this deep water takes place. If future pumping from deep parts of the aquifer is to be studied, however, this boundary would need to be further evaluated.

The top model boundary is assumed to be the ground surface, and is unconfined. The overlying Hennessey Group confining unit is assumed to have a small hydraulic conductivity and is included in the model. Limited flow is assumed to take place between the Hennessey Group and the Central Oklahoma aquifer, but the Hennessey Group was not setup in the model as a no-flow boundary. The alluvium and terrace deposits, associated with streams, overly the Central Oklahoma aquifer and were not differentiated for the model. The alluvium and terrace deposits were included in the top of the model, but no attempt was made to determine or simulate the flux through the alluvium and terrace deposits.

Internal boundaries used in this model include wells, streams, and reservoirs. Reservoirs are considered to be general-head boundaries, which simulate flow into or out of a model cell from an external source. The simulation uses a linear relation between the head in the external source and the head in the model cell (Harbaugh, 2005). These boundaries provide controls of the potentiometric surface and the groundwater-flow system. Wells are discharge points where a known volume of water for each time period is removed from the model (Konikow and others, 2009). The wells used in this model were domestic and public-supply wells.

Stream boundaries were used to simulate all perennial streams in the model area. These boundaries can interact with the aquifer based on the head in the aquifer relative to the stream stage, and the conductivity of the streambed material. Water is routed through each stream reach and in each reach, the flux either to the stream or to the aquifer is determined. Other stream parameters include channel width, slope, roughness, and length. Much of the stream-groundwater interaction is assumed to take place in the overlying alluvial valley deposits, which were too thin to include as a hydrogeologic unit in the scope of this study. The total stream-aquifer flux was constrained using streamflow-gaging stations upstream and downstream from the Central Oklahoma aquifer.

Evapotranspiration, which removes water from the flow system where the groundwater is shallow enough to intersect the root zone, was not simulated in this model directly, but rather was estimated and removed from incoming precipitation when calculating surface recharge using the SWB code (described in the Recharge section of this report). Some unaccounted-for evapotranspiration probably occurs in riparian areas, but estimating the additional flux caused by vegetation was beyond the scope and objectives of this study.

As previously described, recharge is defined here as amount of water that passes the soil root zone, percolates to the regional water table, and becomes part of the groundwaterflow system. Estimates from the SWB code provide a realistic spatial distribution of recharge across the model area, though the amount that reaches the aquifer is approximate and is adjusted when SWB-generated recharge is used in groundwater-flow models.

\section{Numerical Groundwater-Flow Model Construction}

MODFLOW 2005 (Harbaugh, 2005) was used to simulate boundaries and fluxes in the Central Oklahoma aquifer for the numerical groundwater-flow model. The files for the model were constructed using ArcGIS Desktop to convert spatial data to tabular files that can be read by the MODFLOW program. The Central Oklahoma aquifer was simulated using a grid composed of 105 columns by 122 rows of 3,280-ft by $3,280-\mathrm{ft}$ (1-km by $1-\mathrm{km})$ size and 11 horizontal layers, each 100 -ft thick (30.48 meters) (figs. 38 and 41). Figure 39 shows the layers for the percent sand analysis, which were not analyzed for the Hennessey Group confining unit. However, the Hennessey Group is included in the model and the model layers would look similar to figures 38 and 39. Layers included the vertical thickness of the Central Oklahoma aquifer and the Hennessey Group confining unit, which was not in a dedicated layer, but distinguished by specification of a relatively small value of hydraulic conductivity. The entire aquifer was 

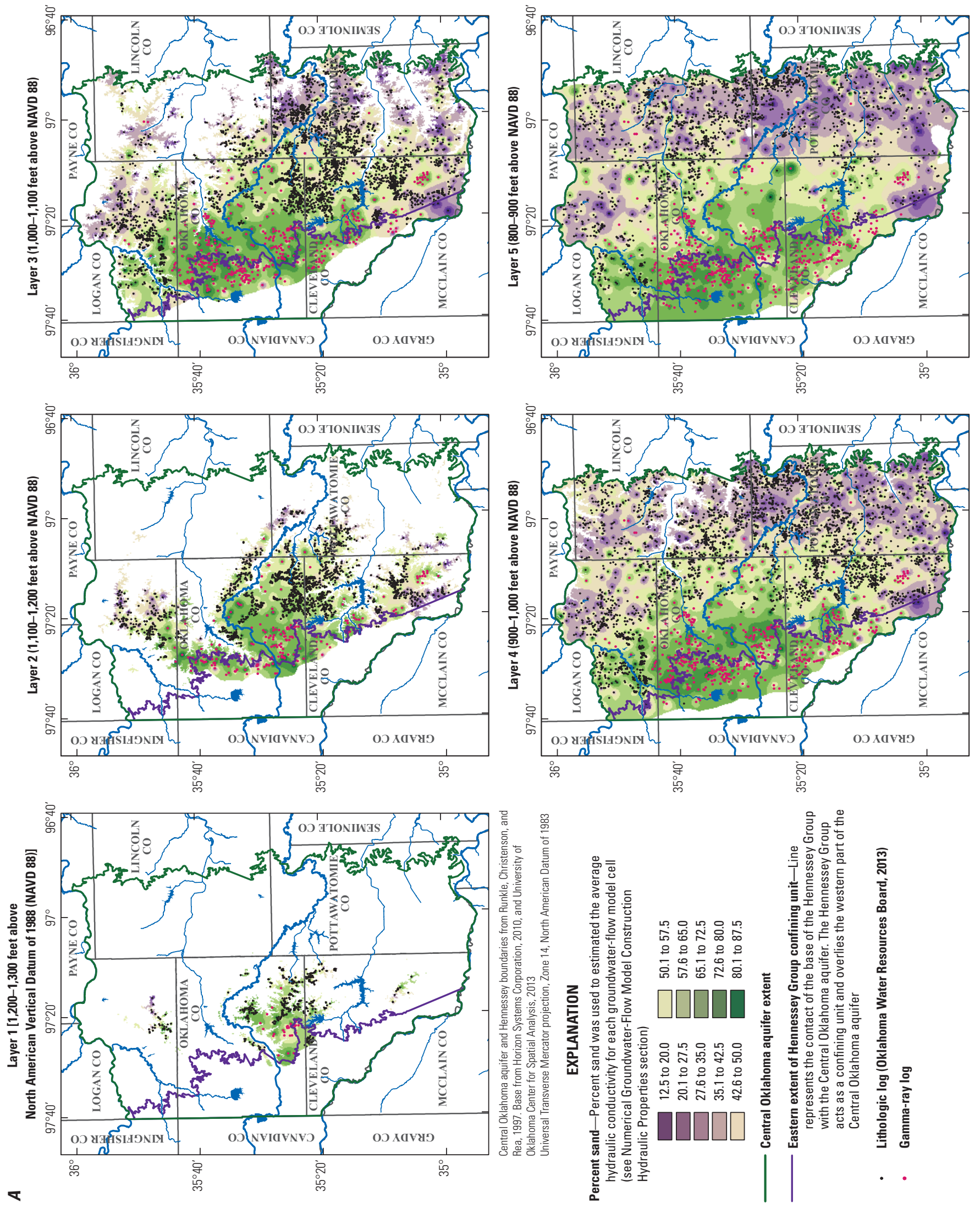

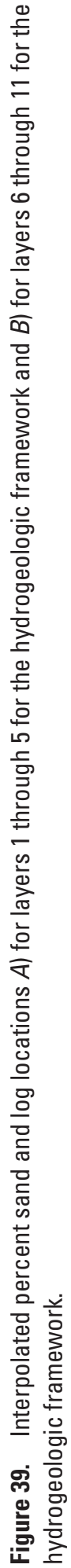



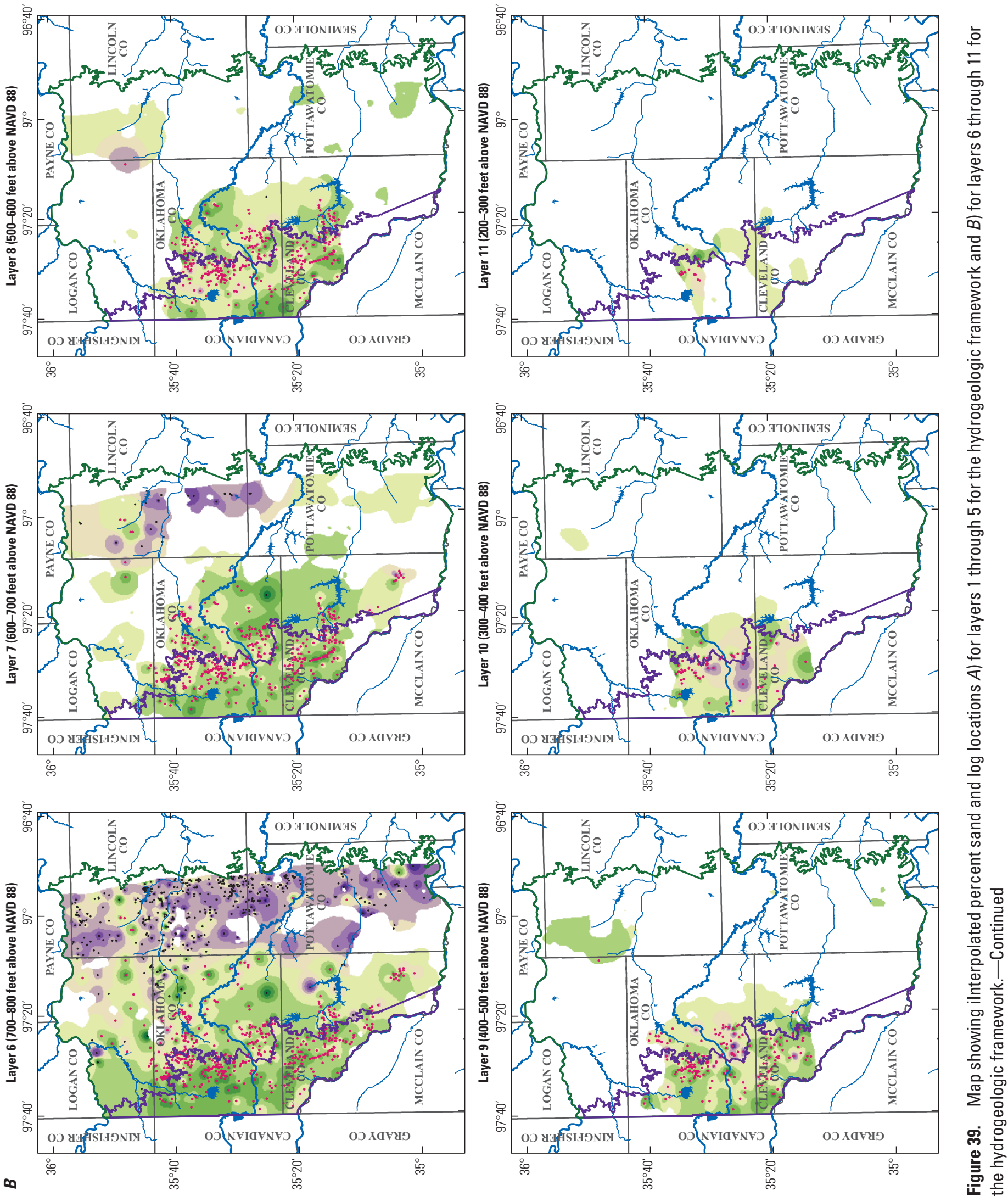

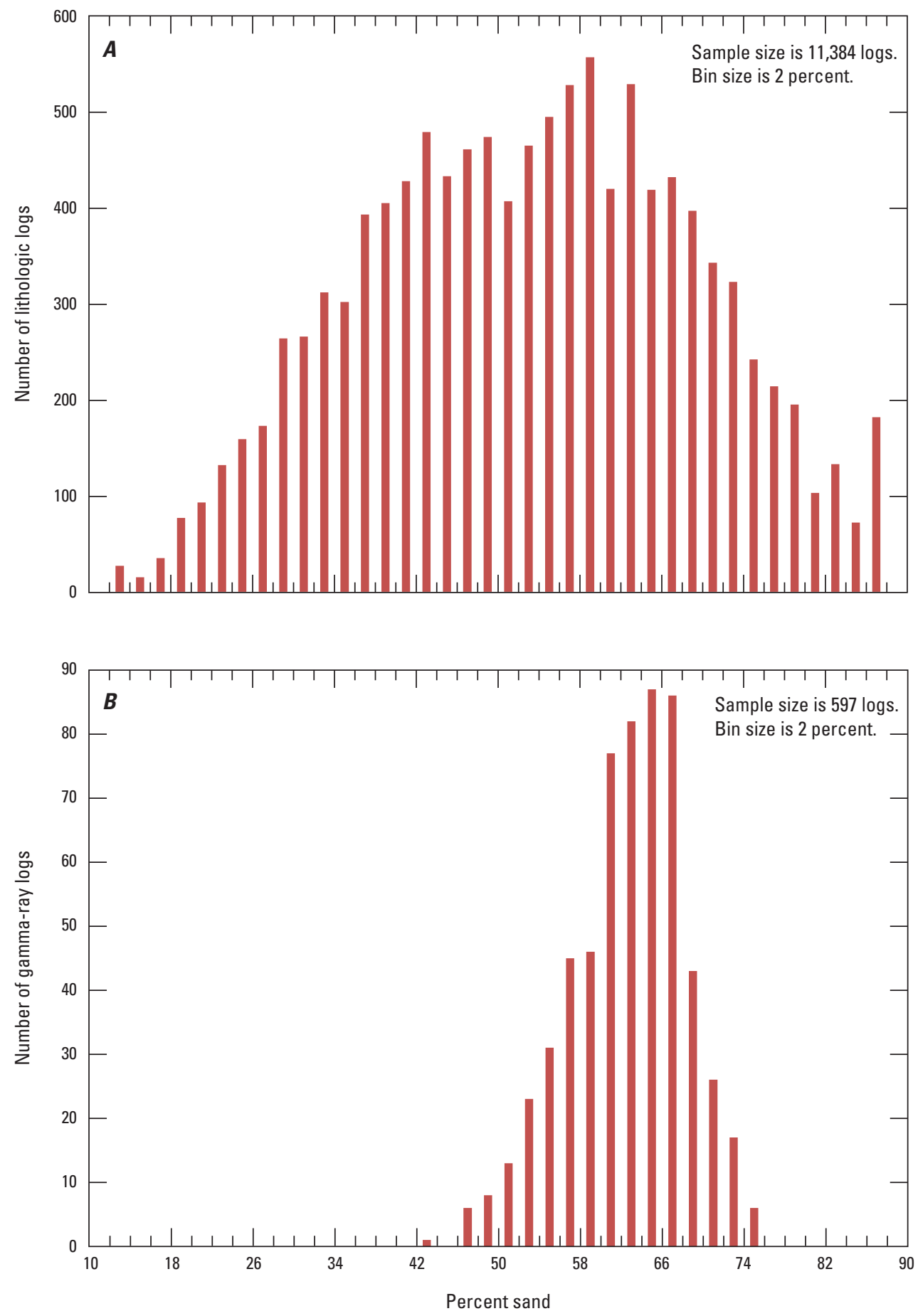

Figure 40. Derived percent sand distributions from $A$ ) lithologic logs and $B$ ) gamma-ray logs. 
simulated as convertible, by which confined conditions are simulated when water level in a cell is above the top of the cell, and unconfined conditions are simulated when water level is below the top of the cell. If the water level drops below the bottom of the cell, the cell is simulated as 'dry', and becomes inactive. Rewetting was not simulated. The groundwater-flow equation was solved using the Preconditioned ConjugateGradient package (Harbaugh and others, 2000).

\section{Assumptions}

Using the MODFLOW finite-difference flow model to simulate groundwater flow requires several assumptions about the system being modeled. Assumptions pertinent to this study include the following:

Water flows through the Central Oklahoma aquifer according to Darcian flow principles. - Water is assumed to be incompressible, aquifer properties are homogeneous and isotropic, and behave as if of infinite areal extent. Flow in each cell is laminar and not turbulent.

For the problem under consideration, the Central Oklahoma aquifer can be adequately simulated for an aquifer-scale water-supply issue using 3,280-ft by 3,280-ft cells, and 11 model layers of 100-ft thickness.-Many parameters such as hydraulic conductivity and specific yield are known to change on a spatial scale much smaller than $3,280 \mathrm{ft}$. The average value of measured or interpolated parameters in cells are assumed to adequately model the average flow conditions in the Central Oklahoma aquifer. Also, though the parameters change on a local scale, they are not sampled on the scale of their spatial variance.

The hydrogeologic framework is assumed to be a suitable basis to capture the textures of the Central Oklahoma aquifer and represent the distribution of hydraulic conductivity of the aquifer for the groundwater-flow system.-Aquifer hydraulic properties change quickly in the vertical direction. Ideally, a MODFLOW model would use model layers that represent hydrogeologic units that have consistent and similar hydraulic properties. There are no discrete hydrogeologic units with consistent or distinctive properties in the Central Oklahoma aquifer, however the aquifer does have complex vertical flow paths that require multiple layers, particularly in the near-surface parts of the aquifer. Thus, assigning interpolated and average parameters to cells with a constant layer thickness is assumed to adequately simulate flow entering at the land surface, travel through a complex mix of lenticular sand bodies and mudstone beds, and discharge at wells and streams.

The groundwater-flow system was at an approximate equilibrium during the initial model period of 1987.-Because hydrologic data were not available for a period before groundwater resources were developed, a period when recharge and reported well withdrawals were similar was identified so that the flow system was not in a state of great flux. The year 1987 had similar stresses in comparison with 1986 and 1985 and is assumed to suffice in avoiding the effects of calibrating a model to a system that is undergoing change on a time scale smaller than the model time steps.

\section{Simulation Periods}

Temporal model design is important as a boundary condition that must be scaled to achieve the study objectives of estimating the amount of water in storage and effects to this aquifer based on proposed management plans. Time periods of groundwater-system simulation can be as a steady-state or a transient model that includes changes in system stress and water in storage. In a steady-state simulation, the head in a given model cell does not change with time. The time discretization of the transient model is dependent on the objectives of the model, the rate of changes in stress on the system, and the available model inputs. The objectives of developing a groundwater-flow model were used to simulate flow in the Central Oklahoma aquifer and use a 50-year predictive model to estimate the effects of different pumping scenarios on available water in storage. Thus, a long-term transient model was needed that spanned wet and dry periods and periods of different pumping rates. Because two synoptic water-level measurement events were available for 1987 and 2009, and pumping increased slightly during this 23 -year period, this period was selected for the transient model. The year 1987 was used as an initial quasi-steady-state calibration time period, and the transient model included 1987 and continued through 2009.

The period of the predictive model was 2010 through 2059 (started using 2009 fluxes). Stress periods 1-year long were chosen because the largest stress on the aquifer was the reported well pumping, and the discharge rates reported for these wells were only available on an annual basis.

\section{Boundaries}

Head-dependent and flux-boundary conditions used and described in this section are shown in figure 41. Headdependent flux boundaries are used to simulate flow into and out of aquifer cells based on a specified head in the headdependent flux cell. Specified flux boundaries are used in a numerical groundwater-flow model to simulate flow into and out of aquifer cells based on a specified flux rate. The flux rate is usually initially determined outside of MODFLOW, but can be adjusted in the groundwater-flow model. Specified flux boundaries can be used to represent recharge and withdrawal rates.

\section{Streams}

Stream boundaries were simulated using the Streamflow Routing Package version 2 (SFR2) for MODFLOW (Niswonger and Prudic, 2005). Simulated streamflow enters the model domain from the west in the Cimarron, North Canadian, and Canadian Rivers. The average annual daily mean streamflow at the streamflow-gaging stations nearest to the western extent of the active model area with at least 10 years 


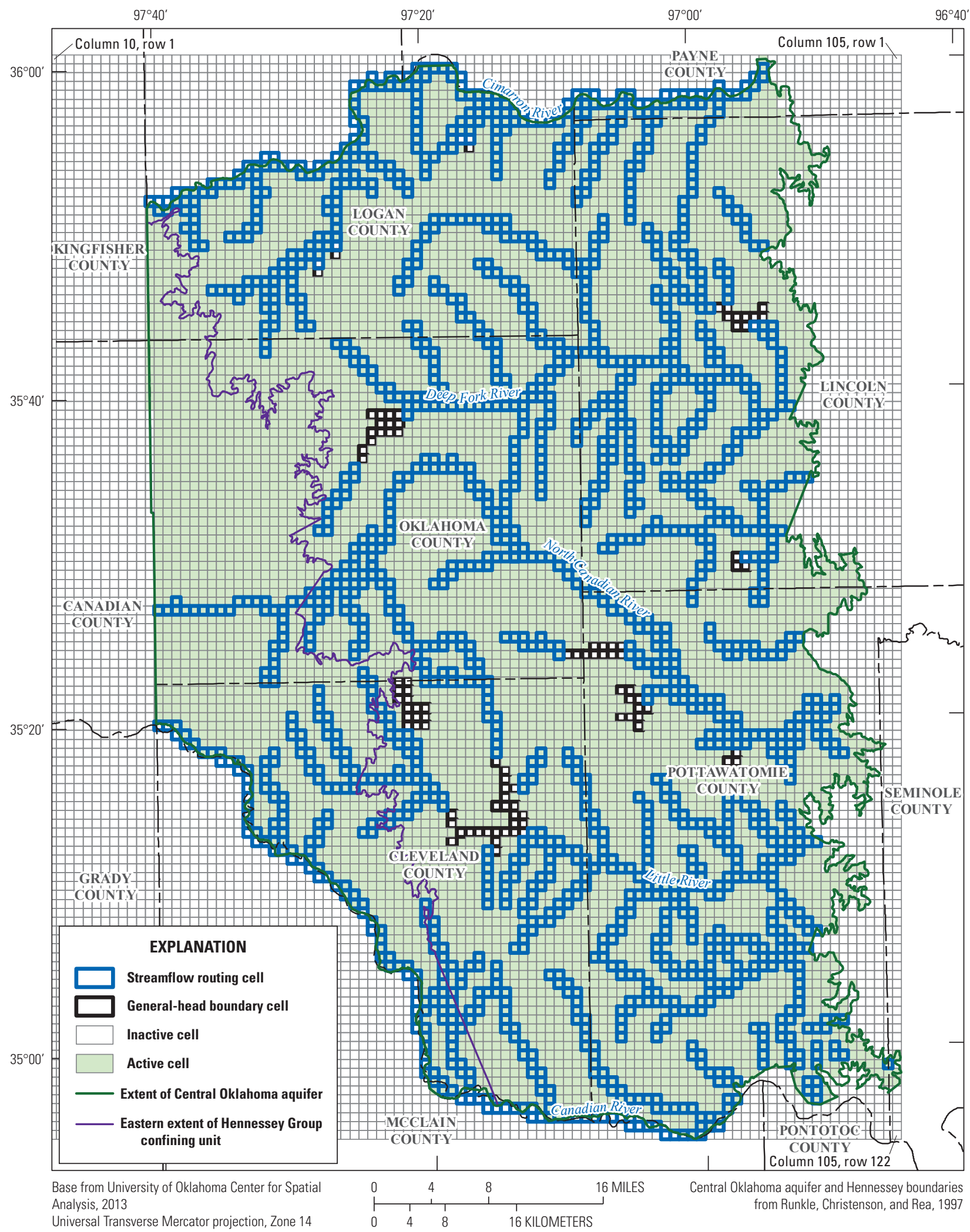

North American Datum of 1983

Figure 41. Numerical groundwater-flow model grid and boundary conditions for the Central Oklahoma aquifer study (cells are 3,280 -foot by 3,280 -foot). 
of record were used to determine inflow rates for each annual stress period in the model. Inflow for the Cimarron River was from the USGS streamflow-gaging stations near Dover, Okla., (07159100) (not shown on figures, outside of map extents). Inflow for the North Canadian River was determined from data collected at the USGS streamflow-gaging station below Lake Overholser near Oklahoma City, Okla., (07241000), and the flow entering the model in the Canadian River was determined from data collected at the USGS streamflow-gaging station at Bridgeport, Okla., (07228500) (not shown on figures, outside of map extents).

Simulated streams that originate in the active model area include the Deep Fork and Little Rivers, and numerous small tributaries. The channel conductance for all stream segments was set at 1.5 meters per day, similar to that of unconsolidated fine sand and silt (Fetter, 1994). The channel widths of all modeled streams were provided by the OWRB (Maria Moreno, Oklahoma Water Resources Board, written commun., 2011; fig. 42). The streambed altitude of each stream segment was derived from DEM grids (http://ned.usgs.gov/).

\section{Lakes}

Lakes were simulated as general head boundaries (GHB), which simulates flow into or out of a model cell based on the relative head between the cell and surrounding cells. The GHB package (Harbaugh, 2005) uses a linear relation between the head in the external source and the head in the model cell. Only lakes east of the Hennessey Group outcrop were modeled, including Arcadia, Bell Cow, Stanley Draper, Guthrie, Langston, Liberty, Meeker, Shawnee, Tecumseh, Thunderbird, and Wes Watkins (see fig. 6 for lake locations). Because the transient-stage levels in these lakes were not recorded, the head in GHB cells were set to the level of the lake provided on USGS topographic maps and was assumed to remain constant throughout the model run. Conductivity for each GHB cell was set at one-half the estimated hydraulic conductivity of the aquifer at that location to account for finer sediments that are typically at the bottom of lakes. Lakes with stream inflows were modeled with SFR2 and flow was routed through the lakes with no losses or interaction with the aquifer; the same discharge was assumed to leave the lake as entered.

\section{Recharge}

Recharge was simulated in the numerical groundwaterflow model using the recharge package $(\mathrm{RCH})$, which distributes recharge to the top of the model at a specified rate (Harbaugh, 2005). Spatial distribution of recharge rates for the simulated time periods for the groundwater-flow model were estimated using climate data and the SWB code. Because water leaving the root zone does not necessarily reach the water table, SWB recharge was adjusted using two multiplier grids. Recharge was applied to the uppermost model cells located near the land surface. Therefore, recharge was applied to parts of model layers because the land surface was not represented by only one layer (fig. 38).

\section{Withdrawals}

Withdrawals from the Central Oklahoma aquifer were simulated in the numerical groundwater-flow model using the multi-node well package version 2 (MNW2), which simulates withdrawals from wells connected to more than one node of the finite-difference model grid (Konikow and others, 2009). MNW2 simulates pumping from multiple layers using the pumping head in each layer, the length of well screen in each layer, and the well losses caused by several factors such as wellbore-skin effect. During the simulation, if a layer went dry, the layer was excluded from pumping, which was useful for the depletion scenario simulation because a constant pumping rate could be set for a hypothetical well, and the aquifer could dry up without affecting the pumping until the lowest active layer was dry. The MNW2 package also provides for well-bore flow between layers. This flow can be an important aspect of the flow system if there are vertical head gradients, such as when a well at depth is pumping. Many of the modeled wells had well-bore flow.

Water use reported to the OWRB includes uses for public-supply, irrigation, industrial, power, mining, commercial, and other. Reported water use was compiled by the OWRB for the simulated time periods for the groundwater-flow model (figs. 19-23). The annual water use for each permit holder was related to specific wells so that these water-use data could be incorporated as withdrawals for each groundwater-flow model cell. The perforated intervals were provided for wells with well log information, and these intervals were assigned to the model layer in which they were located using MNW2. For wells without gravel pack and screen information, or lacking well-log information, withdrawals were assumed from each layer by using the completion depth. Wells for which reported use was simulated in the numerical groundwater-flow model are shown in figure 42. Domestic water use is not regulated by the State of Oklahoma and was estimated using census population data for the simulated time periods for the numerical groundwater-flow model as described in the Withdrawals for Groundwater Use section.

Public-supply wells completed in the Central Oklahoma aquifer are typically constructed to depths ranging from approximately 350 to 800 feet below land surface with gun-perforated openings in stainless steel or polyvinyl chloride casing in a cement annulus, as described in OWRB well-completion reports for public-supply wells. Wells that are gun-perforated do not allow groundwater to flow into the well from the nonperforated zones. A small percent of publicsupply wells completed in this aquifer have gravel-packed annulus and screen, wire-wrap, or slotted openings. Reported wells were included in the model using their locations. The depth to the top and bottom of each perforation or screen was used to determine the layer from which they withdrew water. The pump was assumed to be placed at the midpoint of all perforations or screens. The total reported pumping for a given year was converted to cubic meters per day and applied to each well. If two wells were located in one model cell, MNW2 


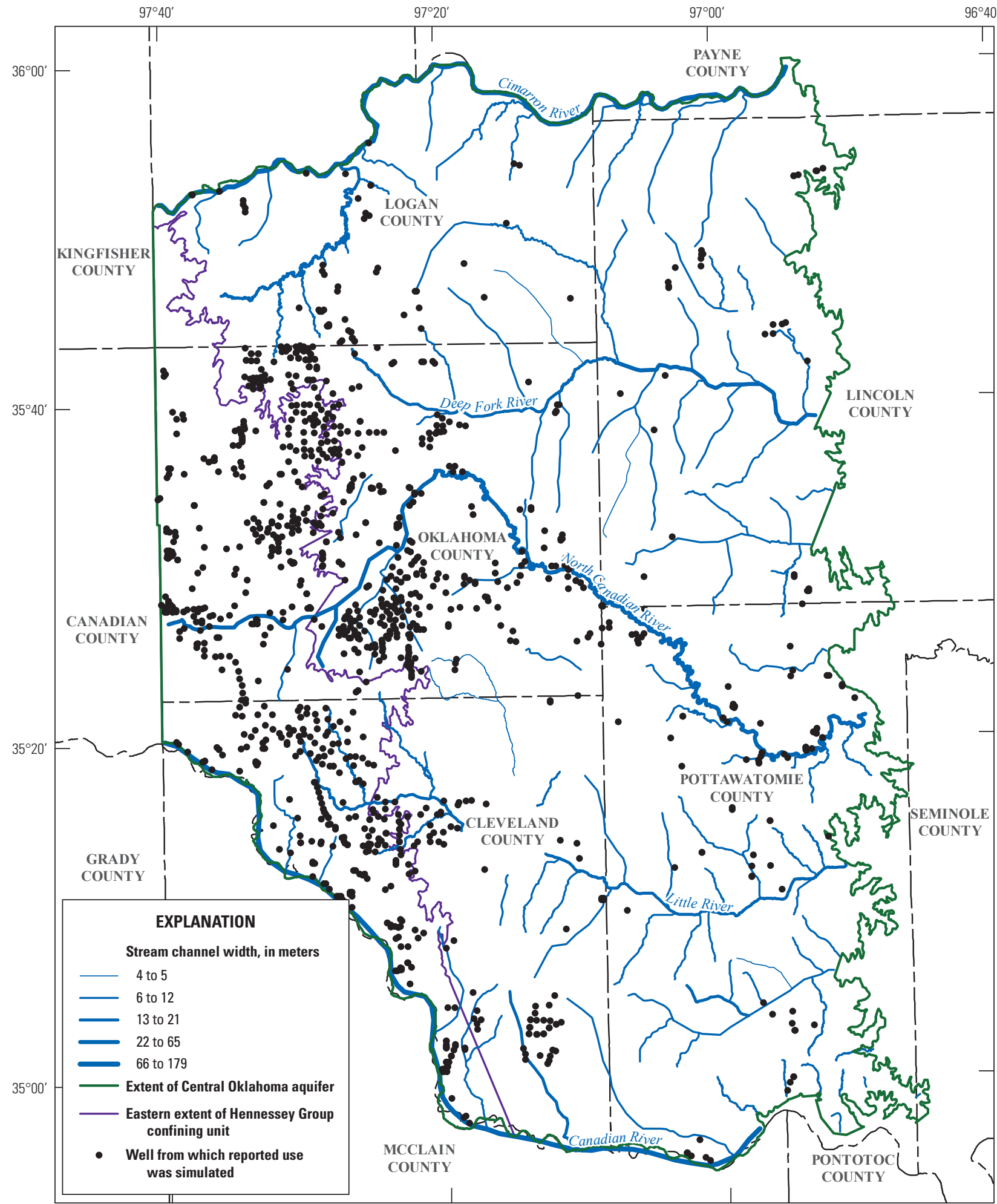

Base from Horizon Systems Corporation, 2010, and University of Oklahoma Center for Spatial Analysis, 2013 Universal Transverse Mercator projection, Zone 14 North American Datum of 1983

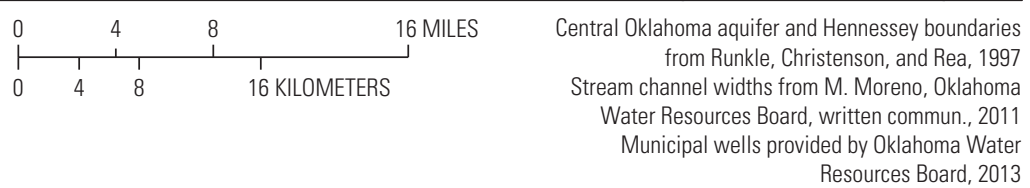

Figure 42. Stream channel widths and wells from which reported use was simulated in the transient groundwater-flow model for the Central Oklahoma aquifer. 
calculates the extraction from each layer, and MODFLOW takes the sum of all wells in each layer in each cell.

Well drillers are required to submit well-completion reports to the OWRB for water wells drilled in the State of Oklahoma. The well-completion reports for domestic wells describe information about well construction, location, and owner, but no records are kept for quantities of water use from domestic wells. Domestic wells in the Central Oklahoma aquifer typically are completed to depths of less than 300 feet, with slotted polyvinyl chloride or stainless steel casing near the bottom of each well ranging to as much as $20-40$ feet in length, as described in OWRB well-completion reports for domestic wells. The annulus in these domestic wells are usually gravel packed to as high as 15 or 20 feet below land surface allowing groundwater to flow into the well from multiple zones, although a larger percent of groundwater likely will flow into the well nearer to the location of the well pump intake in the screen. Irrigation wells completed in the aquifer typically are constructed similarly to domestic wells although irrigation wells may be completed to deeper depths.

The depths (from well-completion reports) to which domestic wells are typically completed was analyzed by the OWRB (fig. 43). Domestic wells in the model were assigned a layer below the top of the model based on the depths at which most domestic wells are completed. Domestic use was incorporated into the model as a withdrawal using the MNW2 package. As domestic wells are typically gravel-packed, the MNW2 package allowed domestic well extraction to be split over multiple layers for each model grid cell stack.

\section{Hydraulic Properties}

Hydraulic properties of the groundwater-flow model were estimated for the aquifer and the confining Hennessey Group. Hydraulic properties for the groundwater-flow model initially were estimated using the three-dimensional distribution of percent-sand values from the hydrogeologic framework.

Hydraulic conductivity for model cells representing the Hennessey Group was set to $1.0 \times 10^{-4} \mathrm{ft} / \mathrm{d}$. The extent of the base of Hennessey Group for the model was determined from a previous structure-contour map of the altitude of the base of Hennessey Group (fig. 6).

To estimate the average hydraulic conductivity in each model cell representing the Central Oklahoma aquifer, a mathematical relation was developed to relate the percent sand to the hydraulic conductivity using published values for fine sandstone and silty claystone. Hydraulic conductivity of 3.3 feet per day ( $\mathrm{ft} / \mathrm{d}$ ) was assumed for fine sandstone (sand from percent-sand analysis) and $0.33 \mathrm{ft} / \mathrm{d}$ for silty claystone (mud from percent-sand analysis) after Domenico and Schwartz (1998). This range spans grain sizes expected to be in the model cells and also includes the $2.4 \mathrm{ft} / \mathrm{d}$ hydraulic conductivity estimated at the Norman aquifer test. The minimum average percent sand for a cell estimated from lithologic and gamma-ray logs was 12.5 percent, and the maximum percent sand was 87.5 percent. Assuming that the minimum hydraulic conductivity of $0.33 \mathrm{ft} / \mathrm{d}$ is represented by 12.5 percent sand, and $3.3 \mathrm{ft} / \mathrm{d}$ is represented by 87.5 percent sand, and that a linear relation exists between percent sand and hydraulic conductivity, then the approximate average hydraulic conductivity for any cell was assumed to be:

$$
H_{k}=\left(0.0396 \times P_{s}\right)-0.165
$$

where

$$
\begin{array}{ll}
H_{k} & \text { is the hydraulic conductivity in } \mathrm{ft} / \mathrm{d} \text {; and } \\
P_{s} & \text { is the percent sand. }
\end{array}
$$

A similar relation was derived for the specific yield of the aquifer, with a linear relation between percent sand and specific yield being:

$$
S_{y}=\left(0.0027 \times P_{s}\right)-0.0233
$$

where

$$
\begin{array}{ll}
S_{y} & \text { is the specific yield; and } \\
P_{s} & \text { is the percent sand. }
\end{array}
$$

This relation is approximate, but no known field measurements exist in the Central Oklahoma aquifer in which a long-duration aquifer test to calculate $S_{y}$ has been completed in an unconfined setting where percent sand was known. This method estimated the minimum specific yield to be 0.01 for silty claystone (mud from percent-sand analysis) and 0.21 for fine sandstone (sand from percent-sand analysis).

Anisotropy, or the ratio of horizontal to vertical hydraulic conductivity, also was estimated from the percent sand, but was not linear. The two longest axes of lenticular sand bodies were assumed to be horizontal. Though the sand bodies may be randomly distributed in a given area, the horizontal hydraulic conductivity will be higher than the vertical conductivity because any horizontal flow path will encounter more sand than a vertical flow path. The maximum anisotropy for the model was assumed to be 10 .

The confined storage coefficient value was assumed to be small (0.0001), similar to the values calculated in available aquifer tests, and was assumed to be uniform and constant for all layers. This storage coefficient value was not adjusted during model calibration.

\section{Quasi-Steady-State Simulation}

A quasi-steady-state model is a transient model that is run with constant aquifer stresses for one stress period. The quasisteady-state model was run to simulate the 1987 calendar year with equilibrium in flow and minimal changes in storage. The year 1987 was chosen for the steady-state model because there were few water-level data available for model calibration prior to this year. A quasi-steady-state model was chosen because there are pumping stresses in the aquifer during 1987. The initial model run was a long-duration transient model that was 


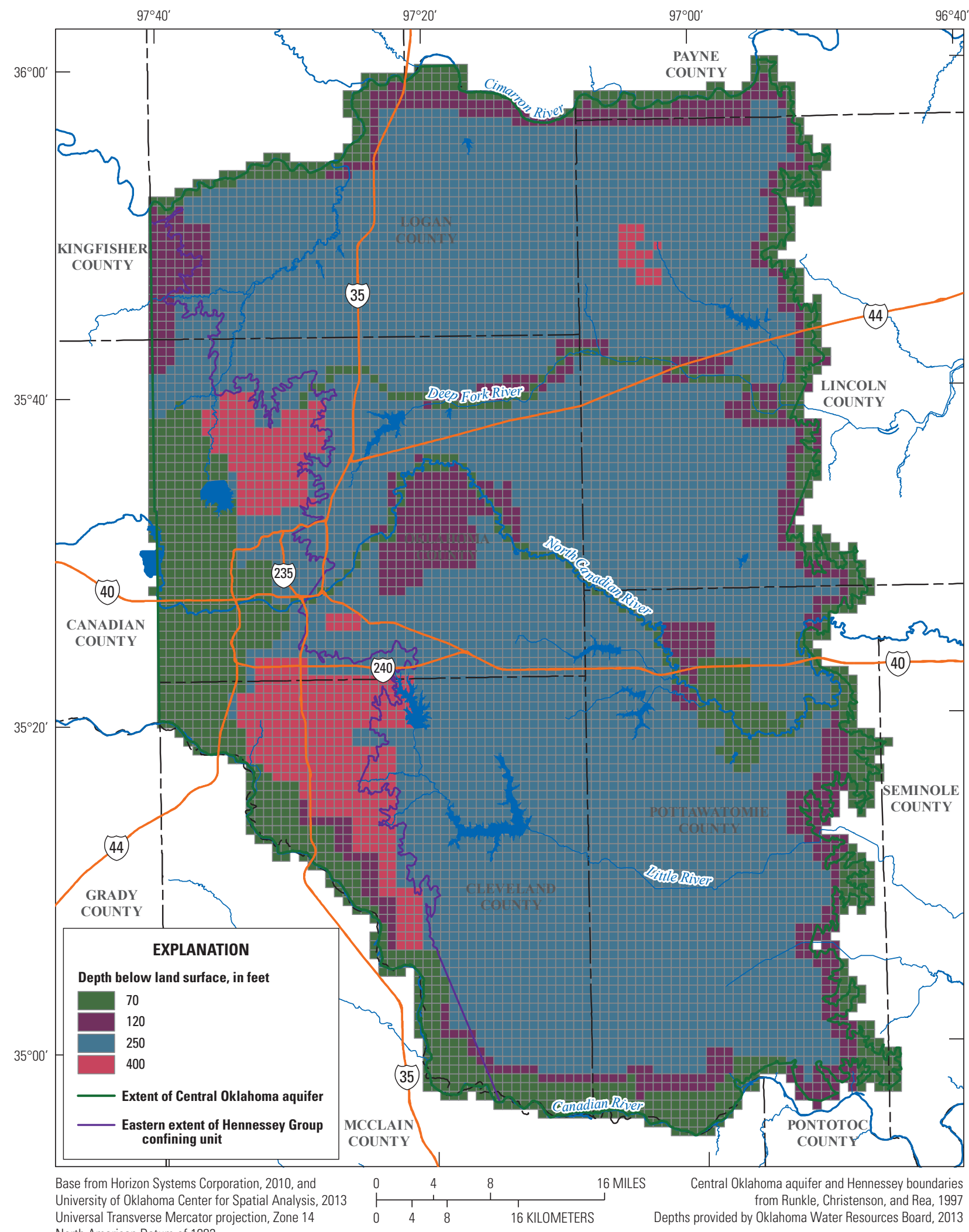

North American Datum of 1983

Figure 43. Depths from land surface that estimated domestic use was withdrawn for the transient groundwater-flow model for the Central Oklahoma aquifer. 
run until there was little change in water in storage, indicating that the flow system was in equilibrium with the inflows and outflows defined for 1987. This model was a quasi-steady-state model and there may have been some differences between this model and a model run in steady-state mode.

\section{Simulation Inputs}

This section describes the simulation inputs that were not adjusted during the calibration process. These inputs include the vertical boundaries described in the Numerical Groundwater-Flow Model section, starting heads, estimated storage parameters, well-construction parameters, and specified heads in boundary conditions. Storage parameters were not used in the quasi-steady-state model because there was no time function and no change in storage.

Two-dimensional arrays were derived for hydraulic conductivity, vertical anisotropy, and specific yield from percent sand across the model area using the methods described in the Aquifer Hydraulic Properties section of this report. The groundwater-flow model did not have layers that were assigned to specific hydrogeologic units. The layers by elevation with assigned hydraulic values provided a method to capture gradual vertical changes in hydraulic parameters and allow for the analysis of vertical flow in the Central Oklahoma aquifer.

Starting heads in the model were from the 1986 to 1987 water-level measurements, described in the Regional Groundwater Flow section of this report. These water levels represented points on the uppermost potentiometric surface of the Central Oklahoma aquifer, and did not include any parts of the aquifer that behave as a confined aquifer because of the overlying Hennessey Group confining unit, or high local vertical anisotropy. This head was applied to all layers of the model to start the simulation, and heads in lower layers were allowed to adjust to stresses and estimated vertical anisotropy.

Inflow to the Cimarron, North Canadian, and Canadian Rivers was set at a constant flow equal to the median mean daily flow for 1987 measured at the nearest upstream streamflow-gaging station. GHB heads were set at the average stage for the reservoir that each GHB cell represented. Conductivity for each GHB cell was set at one-half the estimated hydraulic conductivity of the aquifer at that location.

\section{Calibration Targets}

A subset of water-level measurements made in 1987 was compared to simulated heads to determine how well the simulation mimicked actual groundwater conditions in an assumed equilibrium condition. The subset included observations that were not in the same cell as a pumping well or stream, or were too close to a GHB or no-flow boundary. A total of 262 head observations were included, which sampled layers 2-8.

\section{Calibration Process}

Parameters that were adjusted to affect quasi-steady-state model calibration included hydraulic conductivity, vertical anisotropy, and recharge. The methods used to estimate conductivity and recharge were assumed to better represent the spatial distribution of these parameters than the estimated value of the parameters. Thus, during calibration the spatial distribution was preserved as much as possible while adjusting estimated values. A block diagram of the hydraulic conductivity used in the model is shown in figure 44.

To evaluate the model calibration, the Head Observation (HOB) Package for MODFLOW (Hill and others, 2000) was used. This package compares head targets (head observations) in one or more layers to the heads generated by the simulation, and reports both heads and the difference - the residual - in an output file. The observed heads were each assigned to a model cell using the location, and one or more model layers using the total well depth below land surface (TD) or open intervals. The HOB Package adjusts the simulated head to multiple layers by weighting the heads simulated in each layer by the screened interval in the layer. The layers sampled were biased toward the shallow and middle layers, with no targets in layers 9, 10, or 11 (fig 45). Layer 1 also contained no targets. Because this model is a generalized depiction of highly

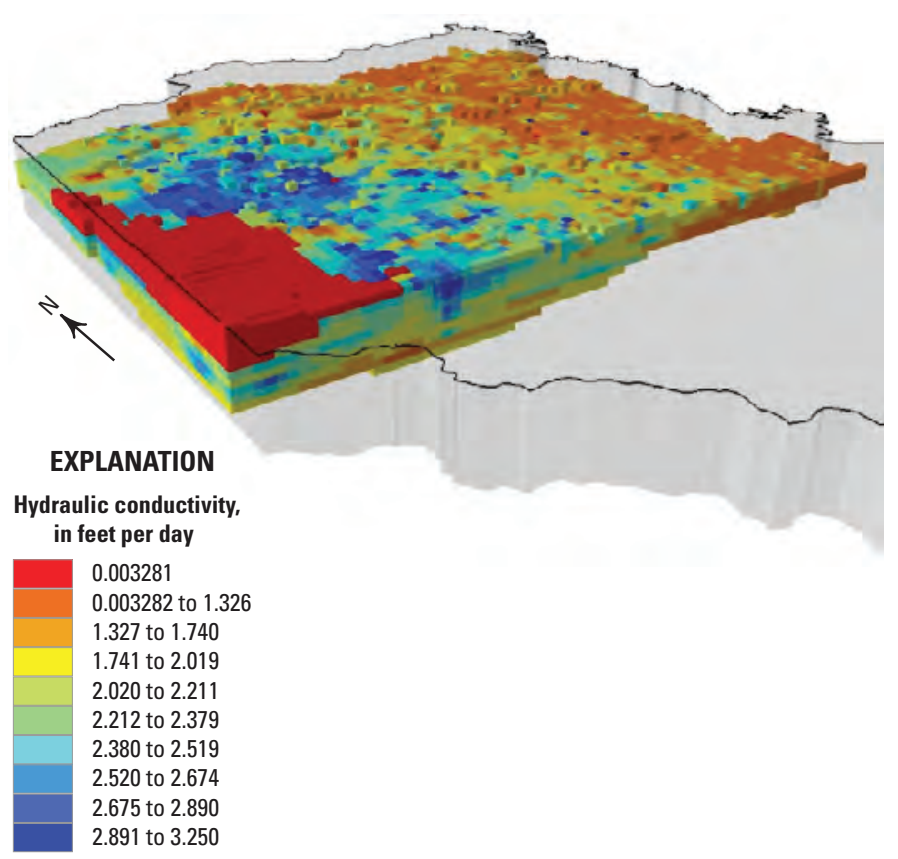

Figure 44. Horizontal hydraulic conductivity per model cell viewed from the southwest and truncated at model row 70 , showing higher conductivity in the center of the aquifer and the low conductivity of the Hennessey Group on the west (red). Surface outline of the aquifer is shown in black and volume is shaded gray. 


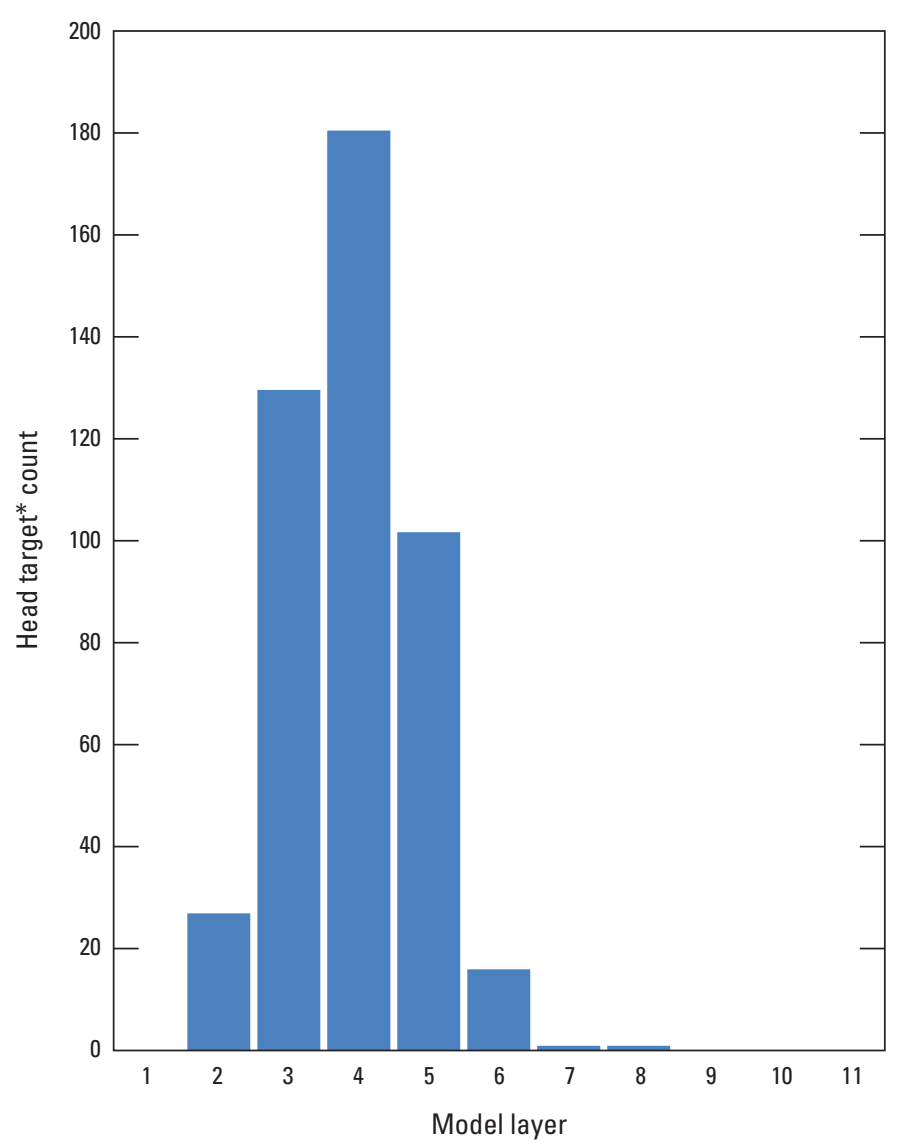

*Head targets are head observations that the groundwater-flow model is calibrated to.

Figure 45. Distribution of head targets by model layer (some head targets were used for more than one layer).

variable local hydraulic properties, there was expected to be a degree of error in the model; at some observation locations, head would not be sensitive to changes in any of the parameters being adjusted to calibrate the model.

The initial method for calibrating the quasi-steady-state model was to scale a given parameter (hydraulic conductivity, vertical anisotropy, and recharge) for an entire layer array by the same multiplier and evaluate the change in model residuals - the difference between the observed head observations and the simulated heads. A multiplier was applied to each parameter one layer at a time, and the change in the summed squares of residuals recorded. The multiplier was then adjusted and the process started again.

Model runs consisted of using the interpolated 1987 potentiometric surface as the initial heads for one run. The resulting heads were saved and used as the starting heads for the subsequent run. This process was repeated for 10 model runs. At the end of the tenth run, the model massbalance discrepancy, the amount of water that entered or was released from storage, and head residuals were recorded. The mass-balance discrepancy indicates how well the numerical groundwater-flow model simulated the system water budget; the lower the discrepancy, the closer the model came to balancing the inflow with the outflow, and converged on a stable mathematical solution.

The amount of water moving in or out of storage is an indication of how well the system is in equilibrium with the quasi-steady-state stresses. The simulation is in equilibrium when the amount of water moving in or out of storage approaches zero.

The summed square of simulation residuals is a measure of how well the entire model simulates the observations from the field (Hill and others, 2000). The lowest layers 9-11 have no observations, but also have no pumping wells or other boundaries, and thus are inferred to have little if any change in head.

When the summed squares of residuals were minimized by scaling parameter arrays, minor changes to local parameters were used to attempt to better match simulated heads with observed heads. Many times, however, heads in these areas were not sensitive to changes in parameters until unreasonable values for parameters were used. In these cases the parameters were not changed, and the residuals were considered to be caused by local variations in parameters that could not be included in the model.

The recharge grid was scaled equally in all cells to achieve the lowest sum of squared error to preserve the spatial distribution of potential recharge calculated using the SWB computer code. The best-fit scale factor for the average daily SWB recharge was 0.4 . Recharge is dependent on the hydraulic conductivity of the aquifer, and hydraulic conductivity is fixed in a range defined by the percent sand and the characteristics of the aquifer. Thus, the recharge appears to be overestimated by the SWB code (fig. 33). Therefore, recharge for the groundwater-flow model was set to 0.4 multiplied by SWB recharge. Scaling back SWB recharge is not unusual for this aquifer because of the small hydraulic conductivity of the Central Oklahoma aquifer.

Head targets were developed from the 1986-87 waterlevel measurements (points and contours shown on fig. 9) and the results of calibration are shown in a map of head-target residuals in figure 46 and a plot of observed heads from 2009 as compared to simulated head throughout the transient model in figure 47. There was no apparent horizontal or vertical spatial bias to model error; the maximum residual was $75 \mathrm{ft}$ $(23 \mathrm{~m})$, and the minimum was $-70 \mathrm{ft}(-21 \mathrm{~m})$, and the average residual was $5.8 \mathrm{ft}(1.78 \mathrm{~m})$. The range in water levels from the 1986-87 measurements was 1.5 to $177 \mathrm{ft}$ below land surface with a median of $32 \mathrm{ft}$. Graphing the simulated heads with the observed heads in figure 47 shows that most of the points follow a trend line with a slope of 0.86 . Substantial scatter and targets in shallower model layers have higher residuals than targets in deeper layers. Layers below the top of the model had simulated heads that diverged more from the observed heads, possibly because they were not sensitive to recharge, and may have been affected by pumping and vertical anisotropy 


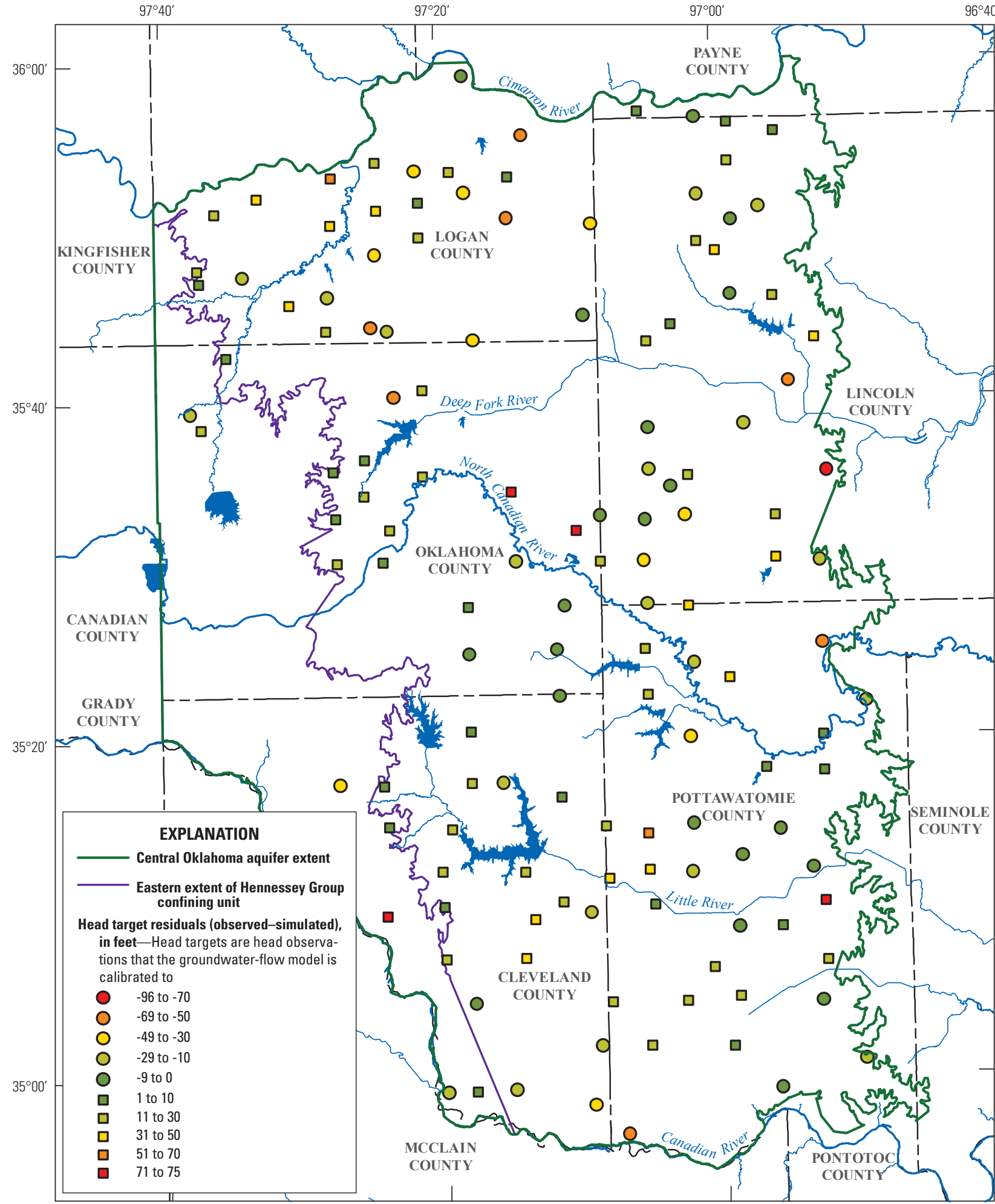

Base from Horizon Systems Corporation, 2010, and $\quad 0 \quad 4 \quad 16$ MILES Central Oklahoma aquifer and Hennessey boundaries University of Oklahoma Center for Spatial Analysis, 2013 Universal Transverse Mercator projection, Zone 14

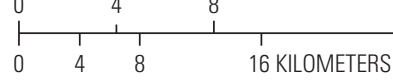
North American Datum of 1983

Figure 46. Targets and residuals for the quasi-steady-state model for 1986-87 measurements. 


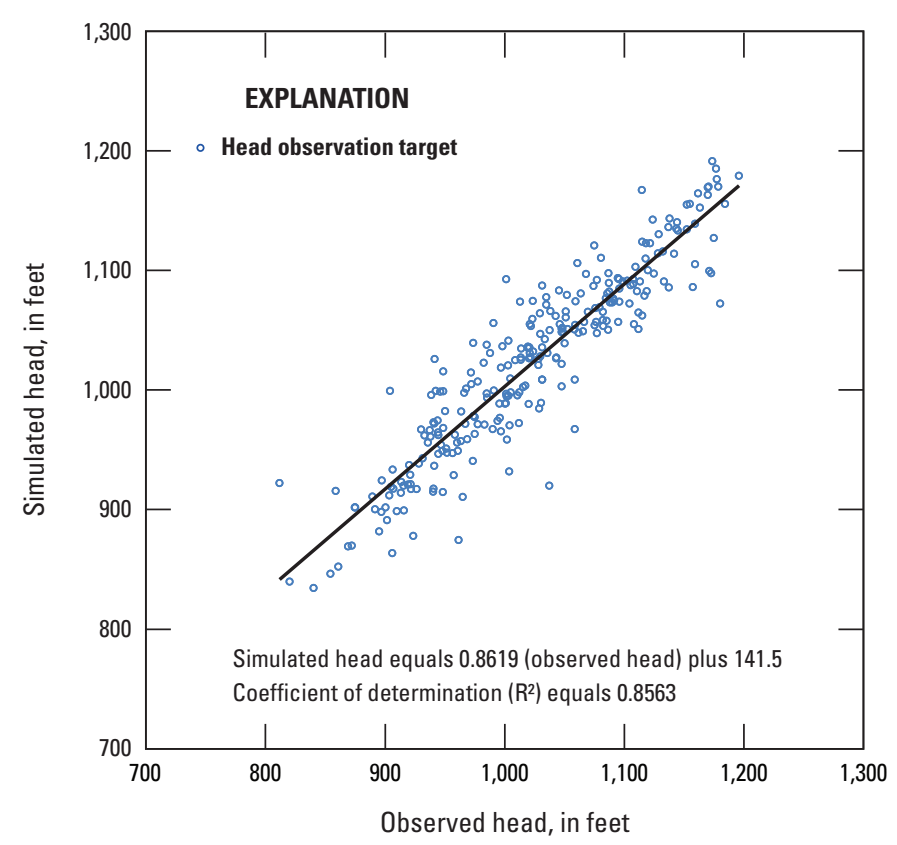

Figure 47. Simulated as compared to observed heads in the quasi-steady-state model for 1986-87 measurements (total number of observations was 262). not resolved in the model. A histogram of the residuals for 1986-87 measurements (fig. 48) has a median of $0.74 \mathrm{ft}$ with a mean of $0.16 \mathrm{ft}$, and skewed positive, indicating that the simulated heads are slightly lower than the observed heads, but most residuals were between zero and $15 \mathrm{ft}$. These results indicate that there is random error in the model, a large component of which is related to the discretization that could not accommodate local variation. Hydraulic heads in the aquifer have been well simulated using the spatial distribution of percent sand. This result is particularly evident where a simulated head that was much higher than an observed head was located close to a simulated head that was far too low. In these cases, no parameter adjusted in the model could account for this error because this adjusted parameter would in all likelihood affect both targets in the same way.

The mass-balance discrepancy of the quasi-steady-state model was low, 0.003 percent, indicating outflows were only 0.003 percent greater than inflows to the model when the model reached convergence. The flux into and out of storage was negligible.

\section{Simulation Results}

The quasi-steady-state simulation provided a reasonable equilibrium condition for the year 1987. Flow to and from storage was nearly zero during the transient run, and head residuals were minimized as much as possible by changing hydraulic conductivity, vertical anisotropy, recharge, and streambed conductance.

\section{Transient Simulation 1987-2009}

The transient model was constructed to cover the period from 1987 through 2009. Each year was chosen as a stress period, because pumping rates for reported wells were only available at annual intervals. Each stress period contained 12 equal time steps.
Figure 48. Residuals from the head targets in the quasi-steady-state model for 1986-87 measurements (total number of observations was 262).

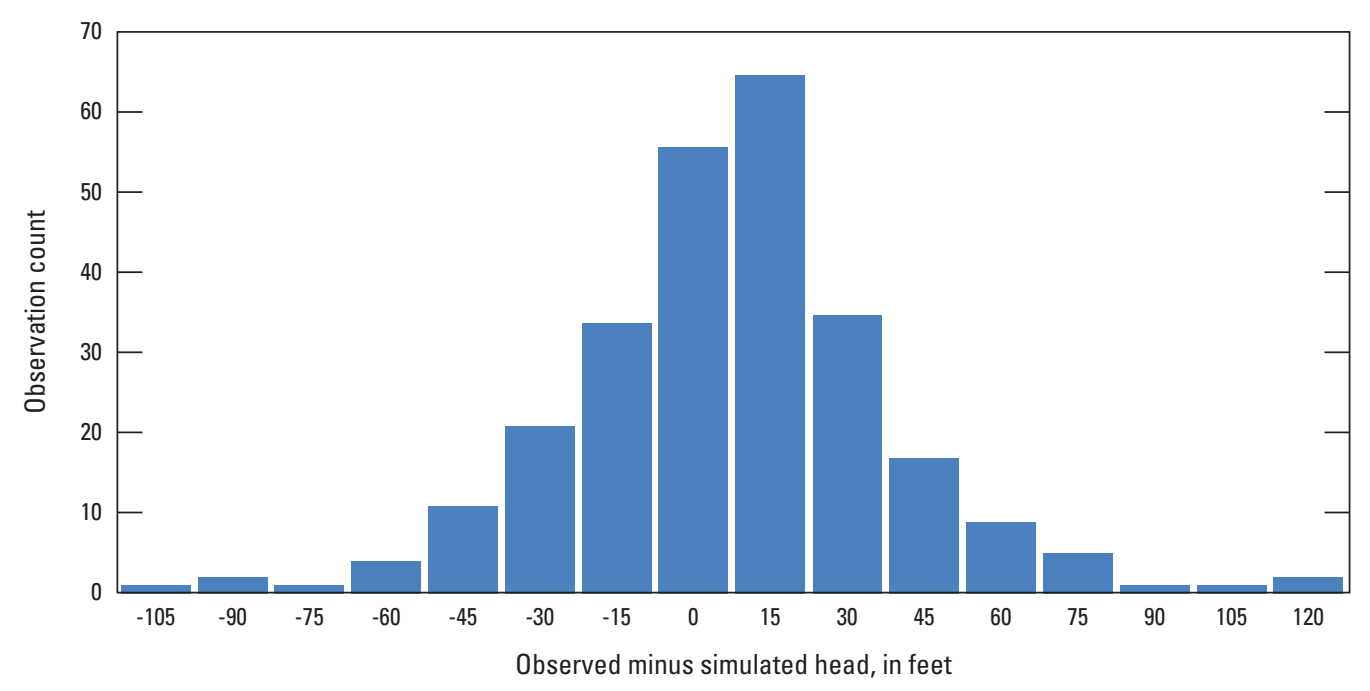




\section{Simulation Inputs}

The hydraulic conductivity and vertical anisotropy from the quasi-steady-state model were used in the transient model and were not adjusted for calibration. Flow into streams entering the model were the median flow for each year at the nearest upstream streamflow-gaging station as described in the Conceptual Flow Model section of this report.

\section{Calibration Targets}

Head targets included all available water-level measurements for the aquifer during the period of the simulation (1987-2009). The HOB package allows heads to be specified for a particular year (which corresponds to a specific stress period), and the number of days in that year. A total of 395 head measurements were used in the calibration process, and some head measurements spanned multiple layers. Because of the two synoptic water-level collection events, the targets are biased toward the first and last stress periods, 1987 and 2009.

\section{Calibration Process}

Parameters adjusted included the specific yield and specific storage of the aquifer, and the average annual recharge rate. Specific yield of the aquifer materials most greatly affects the flow field and heads when water moves in and out of storage. Specific storage is similar, but is only a factor when stresses affect a confined system, and these values are small, having minor effects on calibration in most cases. Specific storage is the amount of water per unit volume of a saturated formation that is stored or expelled from storage owing to compressibility of the mineral matrix and pore water per unit change in head, and has dimensions of 1/length (Fetter, 1994).

Specific yield was adjusted during calibration by scaling the entire array, which was derived from percent sand as described in the Groundwater-Flow Model Hydraulic Properties section of this report. Different scaling factors were used to determine the lowest sum of squared residuals for the entire transient array. Specific storage was not derived from percent sand, and was not known for any part of the aquifer. To get the best calibration and avoid bias, a constant was used for each layer.

Recharge calculated using SWB described in the Recharge section of this report was resampled to a daily average for each year and held constant because of the length of stress periods. Grids of average daily recharge were adjusted by a multiplier for the entire array to preserve the spatial distribution of the relative recharge amounts calculated by SWB. The recharge array was scaled by different amounts until the lowest sum of squared residuals was determined.

The results of the calibration are plotted in a map of model head targets and residuals for the targets in the last stress period (2009) of the model run (fig. 49), a plot of the observed as compared to simulated heads at all targets (fig. 50), and a histogram of the residuals from all targets in the transient model (fig. 51). Figure 49 also includes an approximate distribution of model error, expressed as the absolute value of the head residuals interpolated using inversedistance weighting across the active model area. Figure 49 is a map of the model head error; high model head error indicates areas with less confidence when the model is used to run predictive simulations.

Similar to the quasi-steady-state model, the best calibration was achieved when the SWB potential recharge grid for each year was scaled by 0.4 , indicating that SWB may be overestimating deep percolation volumes related to precipitation. Therefore, a notable part of the deep percolation that advances below the root zone does not enter the Central Oklahoma aquifer, but is lost to evapotranspiration of surface water while still in the soil or in Quaternary-age alluvium overlying or adjoining the Central Oklahoma aquifer.

\section{Simulation Results}

The transient simulation included changes in pumping and recharge driven by changes in groundwater pumping and precipitation, respectively. These stresses on the Central Oklahoma aquifer did not cause large changes in head or flow patterns and appear to be much smaller than the amount of water in storage and recharge. The model budget, listed in table 9, indicates inflows and outflows to the model. The greatest budget discrepancy in the model was 0.09 percent of the total inflow, and the total discrepancy for the entire transient model run was 0.03 percent.

The total flux to and from the model during the transient period is shown by category of boundary condition in figure 52; positive values are inflow to the model and negative values are outflow from the model. The largest inflow to the model is recharge, with water removed from storage, seepage from reservoirs, and stream loss to the aquifer being a smaller amounts. Outflow is dominated by base flow to streams and pumping from wells. The aquifer was in a deficit during this period because inflow to the system from storage was positive (for example, water removed from storage to meet the total outflow). At the end of the transient simulation (2009), the aquifer mean saturated thickness was about $392 \mathrm{ft}$ and the aquifer mean transmissivity was about 1,057 square feet per day (table 10). The simulated available water in storage was about 98.676 million acre-ft (table 10).

\section{0-Year Predictive Simulation}

The purpose of the 50-year predictive simulation was to estimate the change in groundwater in storage if water use continues for 50 years at 2009 rates. The period of the predictive model was 2010 through 2059. The predictive simulation used the calibrated transient model previously described. 


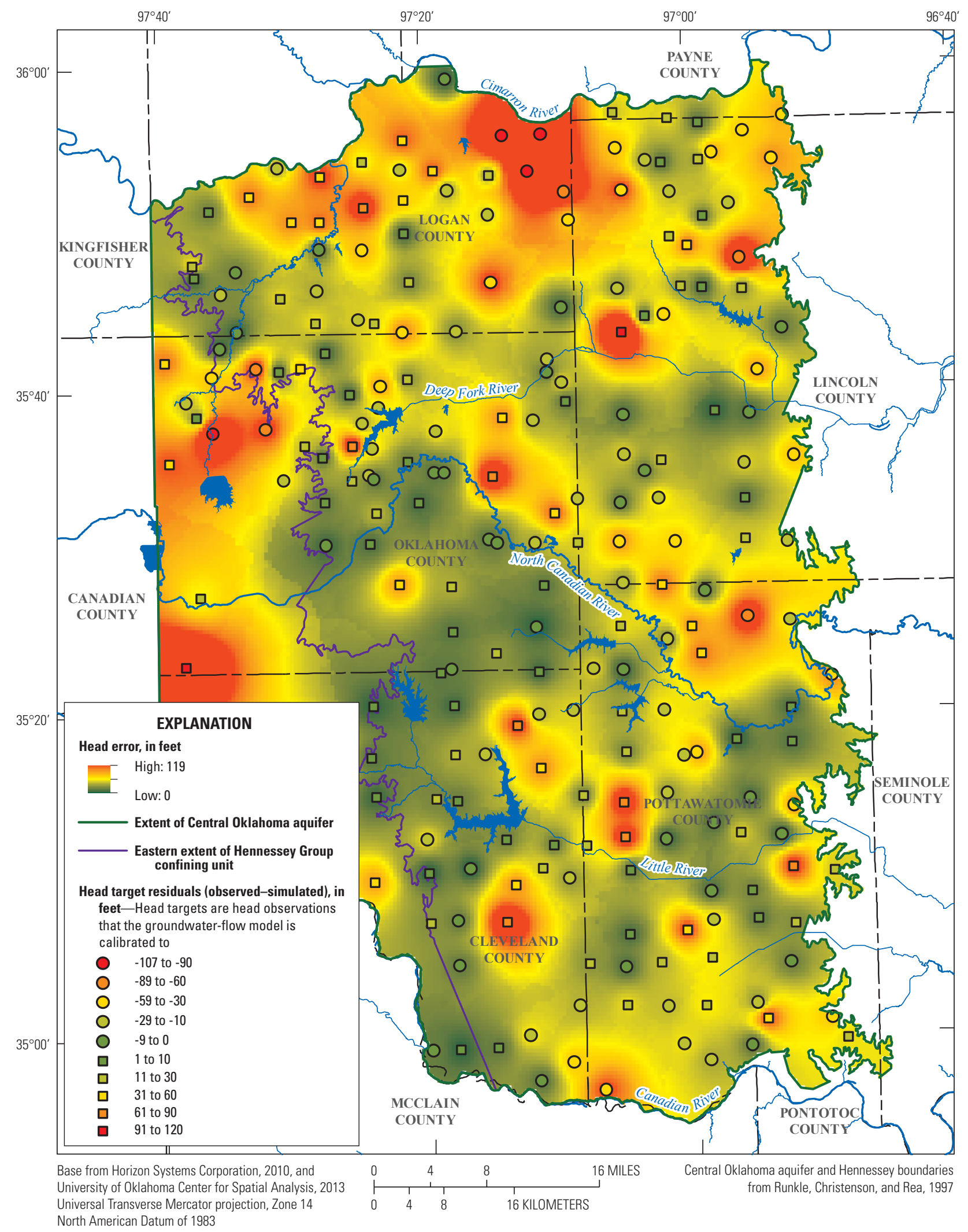

Figure 49. Head residuals and error for the last stress period of the transient model, 1987-2009 (error is the absolute value of head residuals interpolated across the active model area). 


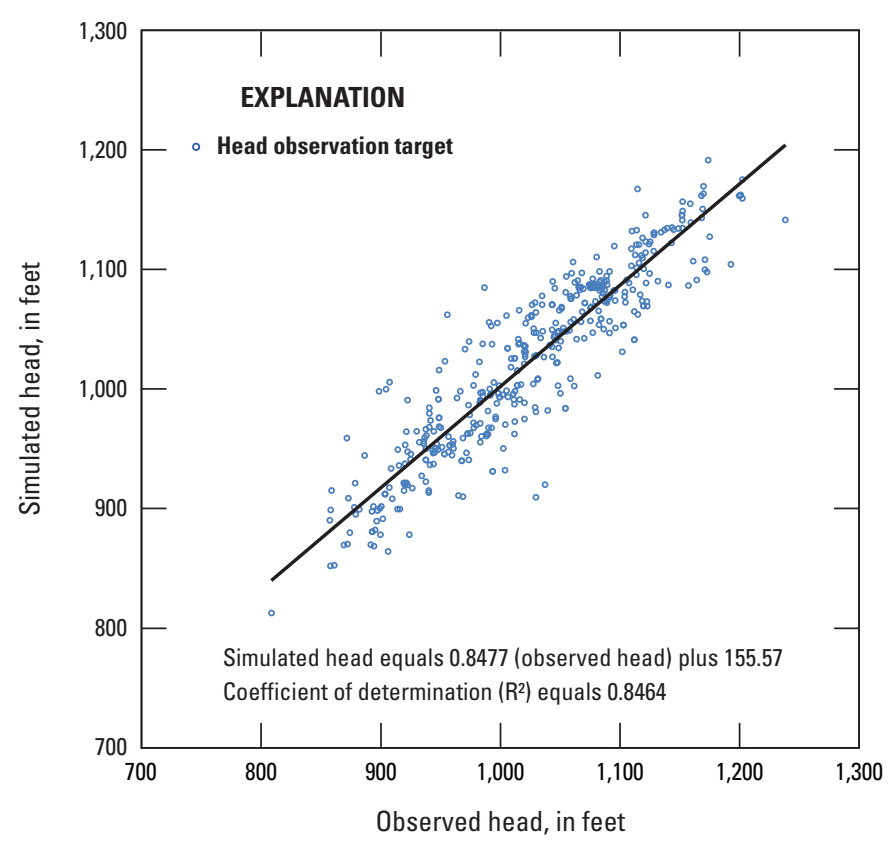

Figure 50. Graph showing simulated as compared to observed heads in the transient model, 1987-2009 (total number of observations was 395).

\section{Simulation Inputs}

The 50-year predictive simulation used the same model inputs as the calibrated transient model except for recharge and pumping. This study did not attempt to simulate effects from a predictive climate model. Therefore, recharge was held constant at the average flux for each cell that was specified for the 1987-2009 time period. Pumping was held constant at the 2009 average daily discharge for each well at about 47,000 acre-feet/year.

Estimation of the effect to water levels in the aquifer by continuously pumping at the 2009 pumping rate for 50 years was achieved by running the model without any pumping, and then running the model with pumping. The difference in heads and water in storage between those model runs was used to estimate the effects to storage in the aquifer.

\section{Simulation Results}

Pumping at the 2009 rate for 50 years with constant recharge resulted in drawdown in upland areas (fig. 53) and reduction of water in storage (fig. 54). The recharge rate was substantially higher than the total pumping rate, but water discharge to streams combined with pumping created a deficit that was met by releasing of water from storage and a decrease in base flow to streams. Groundwater discharge to streams decreased by 100,000 acre-ft/yr over the 50 -year simulation period (fig. 54).

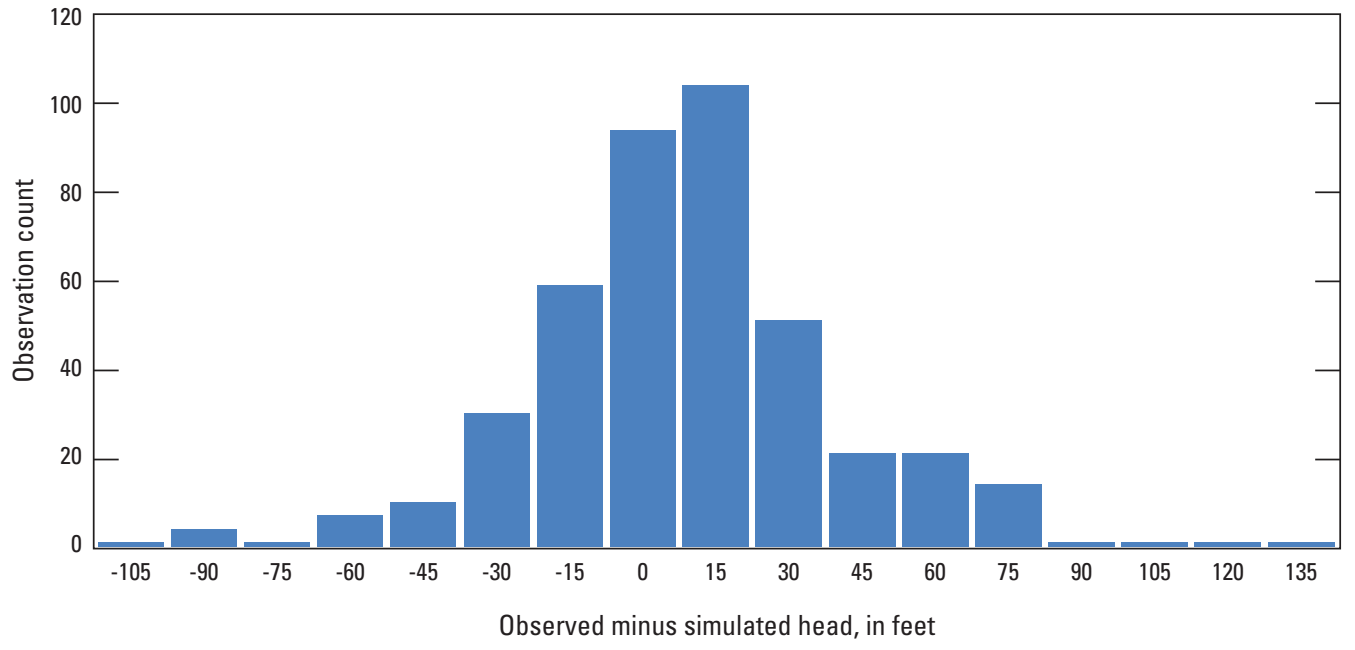

Figure 51. Residuals from the head targets in the transient model, 1987-2009 (total number of observations was 395). 
Table 9. Water budget and inflow-outflow discrepancy for the transient model.

\begin{tabular}{|c|c|c|c|c|c|c|c|c|c|c|}
\hline \multirow{2}{*}{$\begin{array}{l}\text { Stress } \\
\text { period }\end{array}$} & \multirow{2}{*}{ Year } & \multicolumn{5}{|c|}{ Inflow to model in thousand acre-feet per year } & \multicolumn{4}{|c|}{ Outflow from model in thousand acre-feet per year } \\
\hline & & Storage & Lakes & Recharge & Streams & Wells & Storage & Lakes & Streams & Wells \\
\hline 1 & 1987 & 9.173 & 13.285 & 408.992 & 76.741 & 0.123 & 3.354 & 14.030 & 446.784 & 44.138 \\
\hline 2 & 1988 & 112.931 & 13.488 & 292.778 & 79.235 & 0.111 & 16.453 & 13.750 & 423.290 & 44.132 \\
\hline 3 & 1989 & 116.013 & 13.633 & 261.385 & 78.439 & 0.100 & 15.448 & 13.245 & 400.351 & 40.359 \\
\hline 4 & 1990 & 54.295 & 13.633 & 357.563 & 78.695 & 0.098 & 38.031 & 13.224 & 413.220 & 39.586 \\
\hline 5 & 1991 & 63.127 & 13.594 & 333.446 & 79.324 & 0.091 & 31.522 & 13.290 & 403.972 & 40.707 \\
\hline 6 & 1992 & 53.684 & 13.634 & 340.810 & 79.297 & 0.086 & 31.779 & 13.291 & 402.561 & 39.878 \\
\hline 7 & 1993 & 36.065 & 13.557 & 390.168 & 78.235 & 0.085 & 48.585 & 13.318 & 415.984 & 40.051 \\
\hline 8 & 1994 & 65.470 & 13.595 & 317.364 & 77.721 & 0.081 & 22.216 & 13.167 & 396.420 & 42.400 \\
\hline 9 & 1995 & 81.709 & 13.735 & 280.334 & 76.937 & 0.076 & 11.789 & 12.898 & 381.662 & 46.473 \\
\hline 10 & 1996 & 135.698 & 13.987 & 202.768 & 77.836 & 0.070 & 11.953 & 12.408 & 356.703 & 49.111 \\
\hline 11 & 1997 & 101.789 & 14.006 & 235.356 & 75.638 & 0.064 & 13.421 & 12.020 & 354.946 & 46.470 \\
\hline 12 & 1998 & 46.858 & 13.908 & 346.039 & 76.616 & 0.066 & 43.608 & 12.228 & 376.853 & 50.661 \\
\hline 13 & 1999 & 75.843 & 13.903 & 284.885 & 75.577 & 0.064 & 19.119 & 12.308 & 369.357 & 49.457 \\
\hline 14 & 2000 & 26.610 & 13.867 & 375.618 & 76.533 & 0.064 & 44.378 & 12.519 & 385.062 & 50.523 \\
\hline 15 & 2001 & 80.430 & 13.844 & 277.160 & 73.161 & 0.065 & 14.396 & 12.493 & 367.863 & 50.441 \\
\hline 16 & 2002 & 81.061 & 13.974 & 257.254 & 76.406 & 0.056 & 11.373 & 12.157 & 356.851 & 48.203 \\
\hline 17 & 2003 & 76.839 & 14.077 & 258.324 & 76.115 & 0.054 & 8.466 & 11.823 & 353.150 & 51.949 \\
\hline 18 & 2004 & 177.958 & 14.395 & 113.036 & 75.688 & 0.051 & 4.985 & 11.264 & 317.155 & 47.311 \\
\hline 19 & 2005 & 24.034 & 14.228 & 387.411 & 75.558 & 0.052 & 74.771 & 11.398 & 361.496 & 53.063 \\
\hline 20 & 2006 & 137.364 & 14.334 & 163.966 & 76.854 & 0.049 & 13.090 & 11.225 & 322.045 & 45.981 \\
\hline 21 & 2007 & 163.527 & 14.622 & 113.953 & 75.200 & 0.043 & 6.877 & 10.557 & 301.422 & 48.359 \\
\hline 22 & 2008 & 11.518 & 14.347 & 464.839 & 76.665 & 0.051 & 144.522 & 11.038 & 364.617 & 47.265 \\
\hline 23 & 2009 & 100.172 & 14.270 & 208.172 & 74.594 & 0.047 & 11.201 & 11.124 & 327.616 & 47.418 \\
\hline
\end{tabular}

\section{Simulation of Available Water in Storage}

The calibrated transient model also was run to determine how much water hypothetically could be extracted from the Central Oklahoma aquifer over a 50-year period (scenario 1), and the effects of pumping the temporary state-apportioned rate of 2.0 (acre-ft/acre)/yr (scenario 2); Oklahoma Water Resources Board, 2010. The purpose of this analysis was to provide estimates of the amount of water in storage in the Central Oklahoma aquifer.

\section{Methods}

The two scenarios used to determine the amount of water in storage is based on the concept of equal proportionate share described in the Introduction section in this report-the same rate of water extraction for the entire aquifer - which approximates a fully developed aquifer for future water use. The first scenario determined the discharge rate at which wells placed in every model cell would have to be pumped so that just $15 \mathrm{ft}$ (4.57 meters) or less of saturated thickness remained in 50 percent of the aquifer area ( 50 percent of the model cells) after 50 years. The second scenario was to pump 2.0 (acre-ft/acre)/yr from every model cell, and to determine the time at which one-half of the aquifer area was reduced to $15 \mathrm{ft}$ or less of saturated thickness. 


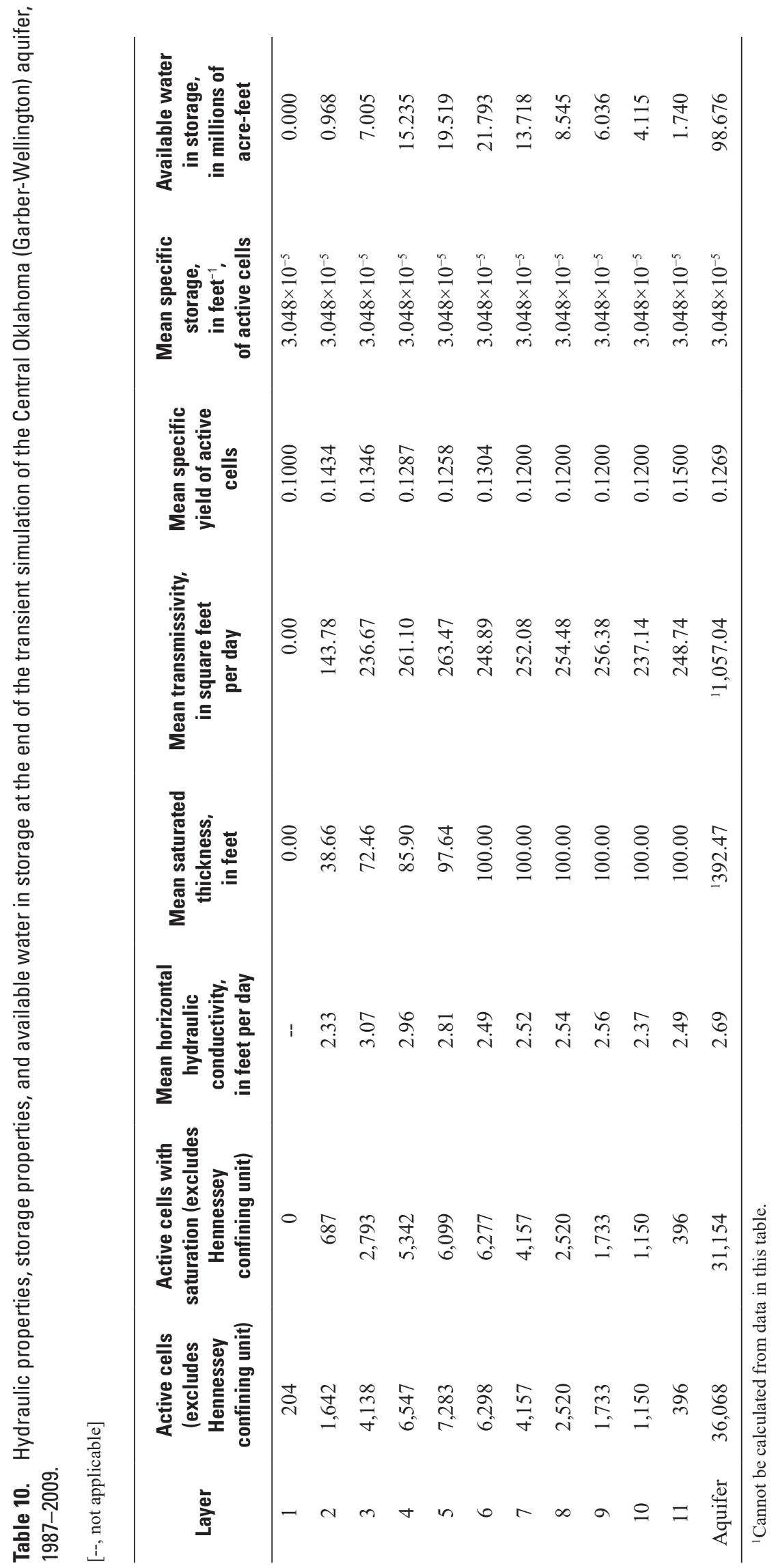




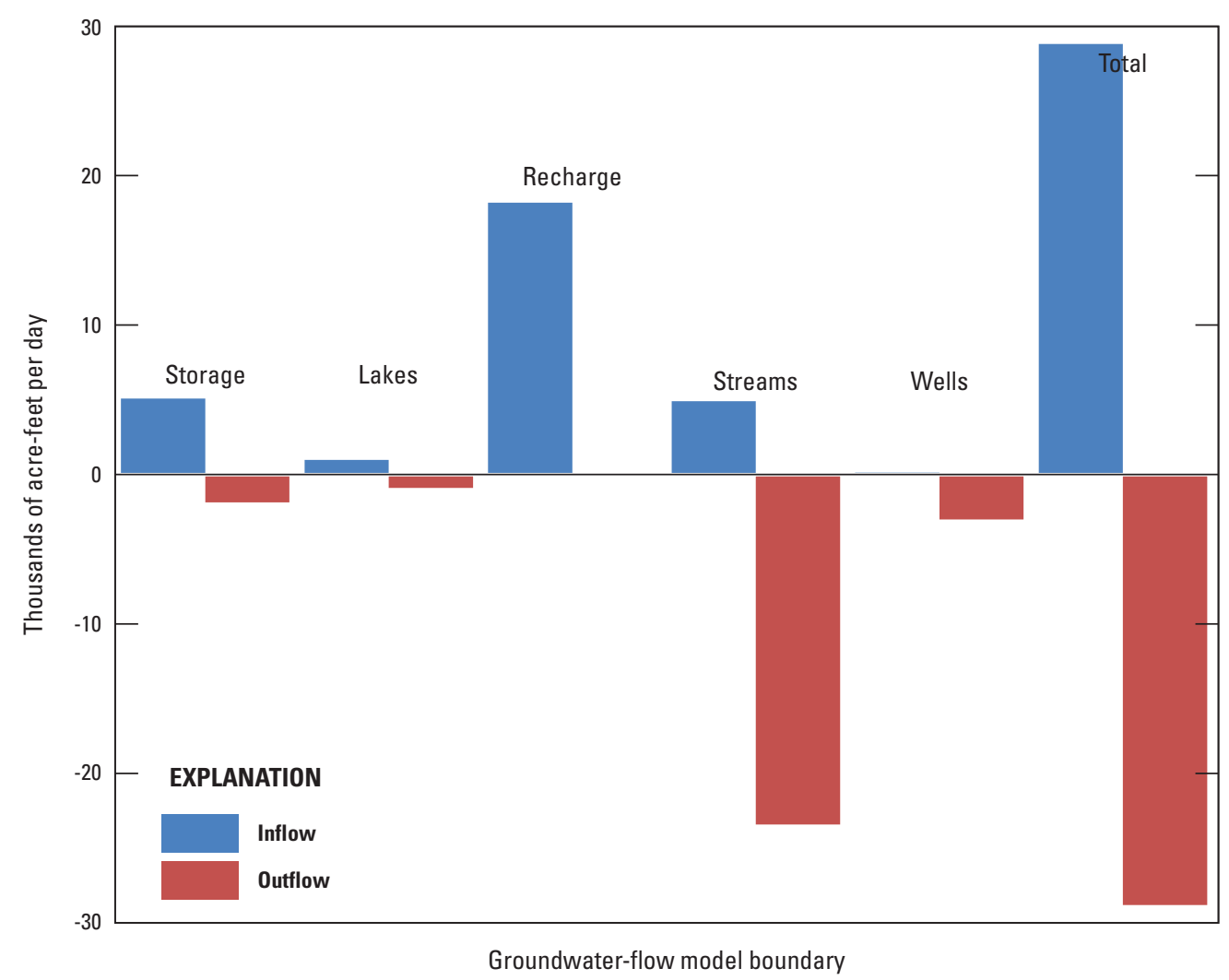

Figure 52. Water budget for the transient model showing total flux for the period 1987-2009, by boundary condition.
These scenarios are somewhat unrealistic because though hydraulic conductivity varies throughout the aquifer and there is substantial vertical anisotropy, the lower model boundary is not a no-flow boundary in reality. Under these pumping conditions, some upward migration of saline water would result, but this migration was not modeled for this study. Determination of the degree to which saline water upwardly migrates was beyond the scope of this study.

\section{Simulation Inputs}

For scenario 1, the transient model was run for a period of 50 years with a hypothetical well in each model cell and pumped from every active layer at that location. The same pumping rate was assigned to each well, and the rate was increased incrementally for a number of model runs until the number of cells with a saturated thickness of $15 \mathrm{ft}(4.57 \mathrm{~m})$ or less equaled 50 percent of the model gridded area. The MNW2 (Multi-Node Well) package allows each well to stop pumping from a cell if that cell dries out during the transient model run.

For scenario 2, the calibrated transient model was run with a multinode well in each cell that was set to discharge 2.0 (acre-ft/acre)/yr for more than a maximum period of 50 years. The saturated thickness was periodically recorded during the 50-year run to determine the year in which one-half of the cells were below $15 \mathrm{ft}$ of saturated thickness.

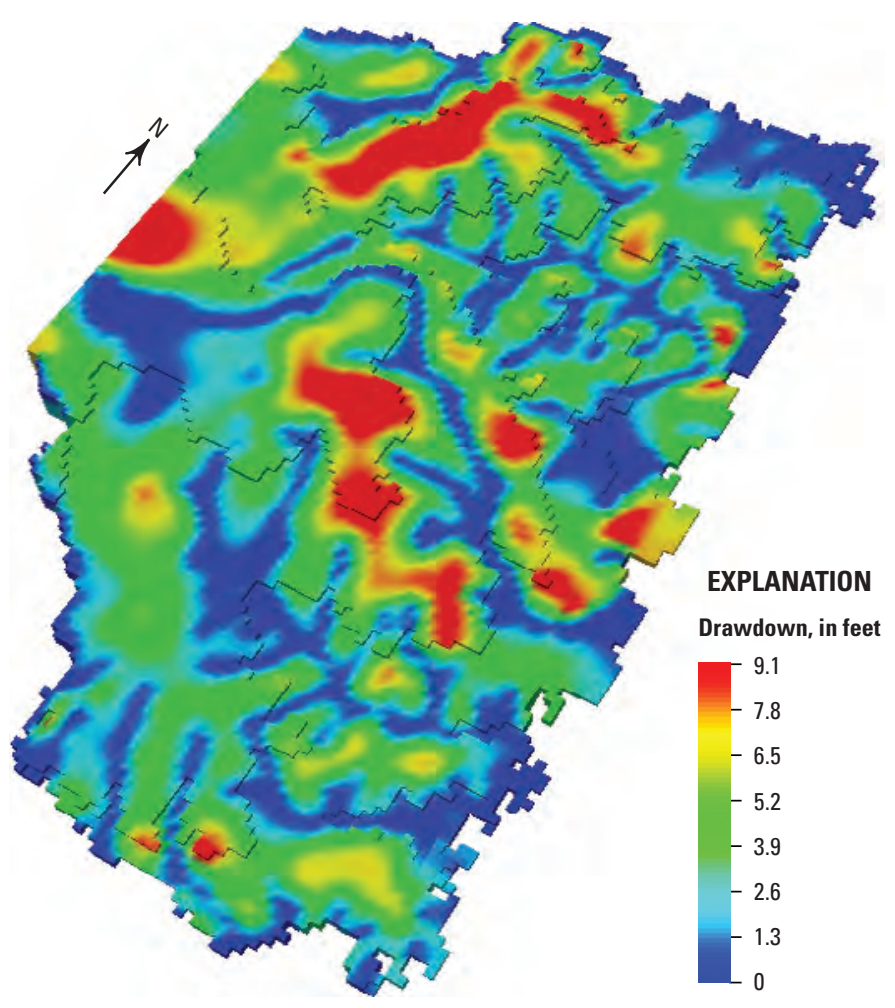

Figure 53. Drawdown in the Central Oklahoma aquifer numerical model after 50 years with 2009 pumping rates compared to the aquifer with no pumping. 
Figure 54. 50-year predictive model budget showing recharge, water removed from storage, groundwater pumpage, and base flow to streams assuming constant recharge and pumping at estimated 2009 rates (50-year predictive simulation).

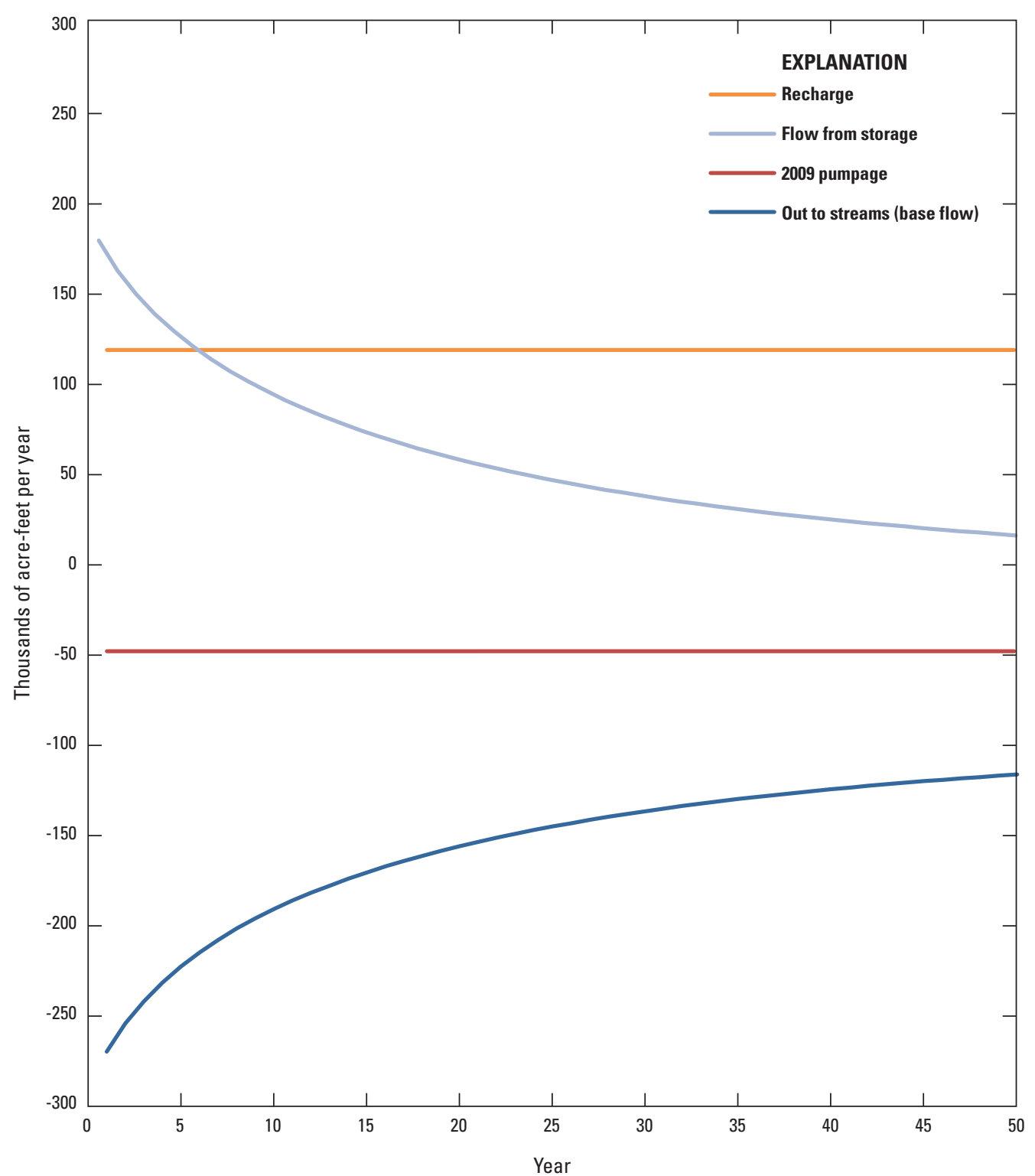

Storage coefficient and specific yield affect the amount of water in storage and were increased and decreased by 10 percent in both scenarios. Storage coefficient and specific yield were adjusted using the same method described in the Sensitivity Analysis section of this report.

\section{Simulation Results}

For scenario 1, the pumping rate at all cells that reduced the saturated thickness in one-half of the cells to or below $15 \mathrm{ft}$ $(4.57 \mathrm{~m})$ after 50 years was approximately between 1.1 and 1.5 (acre-ft/acre)/yr using 10 percent increase and decrease in specific yield. (fig. 55). Simulated heads in scenario 1 indicate that water levels decreased and some model cells went dry first in the eastern part of the aquifer where aquifer thickness is less than $300 \mathrm{ft}$ (fig. 56). The last area of the aquifer with substantially decreased water levels was where the aquifer is the thickest, which is north of Moore near Tinker Air Force Base (see fig. 1 for location). During the 2010-59 depletion scenario, drawdown also was observed below the Hennessey Group (confining unit) in the western part of the aquifer. This drawdown below the Hennessey is not visible on fig. 56 because of the aspect of the maps. Groundwater in the Hennessey Group did not drawdown because the low transmissivity of the Hennessey causes groundwater to be retained in the shale and there was no pumping simulated from the Hennessey Group. Throughout this scenario, pumped water was coming from storage in the aquifer.

The results of scenario 2 are shown in figure 57. The aquifer was estimated to be 50 percent depleted after between 


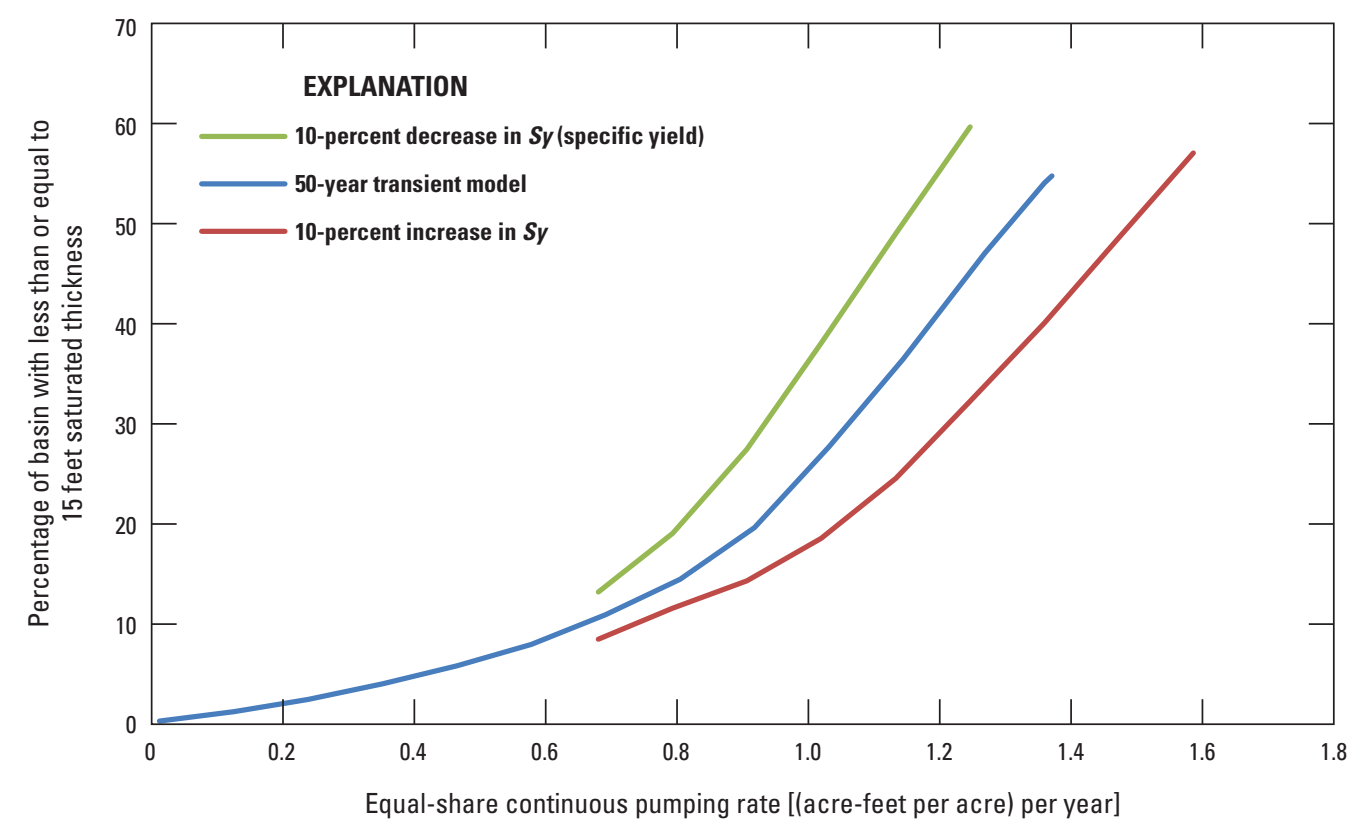

Figure 55. Percent of aquifer that had less than or equal to 15 feet of saturated thickness at various pumping rates at the end of a 50 -year period (scenario 1).
35 and 41 years of pumping 2.0 (acre-ft/acre)/yr using 10 percent increase and decrease in specific yield. This analysis indicates that scenario 2 pumping rate of 2.0 (acre-ft/acre)/yr is not sustainable for more than 41 years if every landowner with a potential well in each acre in the Central Oklahoma aquifer exercised their temporary right to pump at that rate.

\section{Sensitivity Analysis}

A sensitivity analysis was performed on the model, which determines the sensitivity of the calibrated simulation to changes in calibration parameters (hydraulic conductivity, specific yield, specific storage, vertical anisotropy, and recharge). The sensitivity of model heads to changes in these parameters is thus important because the uncertainty in these parameters could have an important effect on the simulation results.

\section{Methods}

All observations were used with the transient simulation for the sensitivity analysis because the quasi-steady-state model was run as part of the transient simulation. The parameters used in the transient model were the hydraulic conductivity, the specific yield, specific storage, vertical anisotropy, and recharge. Each parameter was scaled across the model by multiplying the two-dimensional array for each layer or the recharge for each year by a constant, reducing the multiplier by 10 percent and 20 percent, and increasing the multiplier by 10 percent and 20 percent. For each model run, the average change in head at observation points (from the calibrated model) was recorded.

\section{Sensitivity Analysis Results}

Simulated hydraulic head at head targets in the transient simulation responded to changes in hydraulic conductivity, specific yield, vertical anisotropy, and recharge and are shown in figure 58, and listed in table 11 . The model was most sensitive to recharge, as a 20-percent decrease in recharge caused a 2.58 -ft $(0.79-\mathrm{m})$ drop in average head, and a 20 -percent increase in recharge caused a $2.56-\mathrm{ft}(0.78-\mathrm{m})$ rise in average head. The average change in head was inversely proportional to changes in hydraulic conductivity, with a 20 -percent decrease in hydraulic conductivity resulting in a 1.24-ft $(0.38$ $\mathrm{m})$ rise in average head; a 20-percent increase in hydraulic conductivity caused a $0.85-\mathrm{ft}(0.26-\mathrm{m})$ drop in average head. The model was only slightly sensitive to specific yield, with a 20 -percent decrease in specific yield producing a 0.33 - $\mathrm{ft}(0.10$ m) drop in average head, and a 20-percent increase in specific yield causing a $0.25-\mathrm{ft}(0.08-\mathrm{m})$ increase in average head. A 20 -percent decrease in vertical anisotropy caused $0.016-\mathrm{ft}$ $(0.005-\mathrm{m})$ rise in head, and a 20 -percent increase in vertical anisotropy caused a $0.013-\mathrm{ft}(0.004-\mathrm{m})$ drop in average head.

Small values of sensitivity resulting from changes in storage were most likely related to relatively constant pumping rates, which were smoothed even further by the availability of annual pumping data rather than seasonal or monthly, and a lack of transient head observations that would record seasonal or monthly head changes induced by aquifer stresses. Pumping data were only available in annual totals, which were used in the model as daily average pumping. Thus, with small stresses, water was not moved in and out of storage sufficiently to cause simulated water levels to be sensitive to storage parameters. 
A. 1 Year

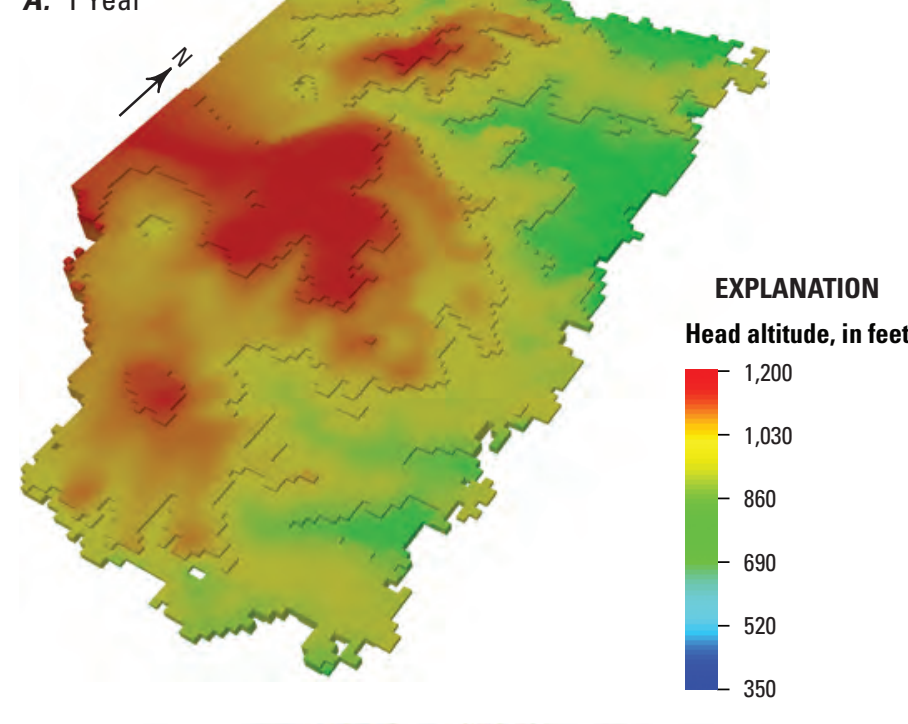

B. 25 Years

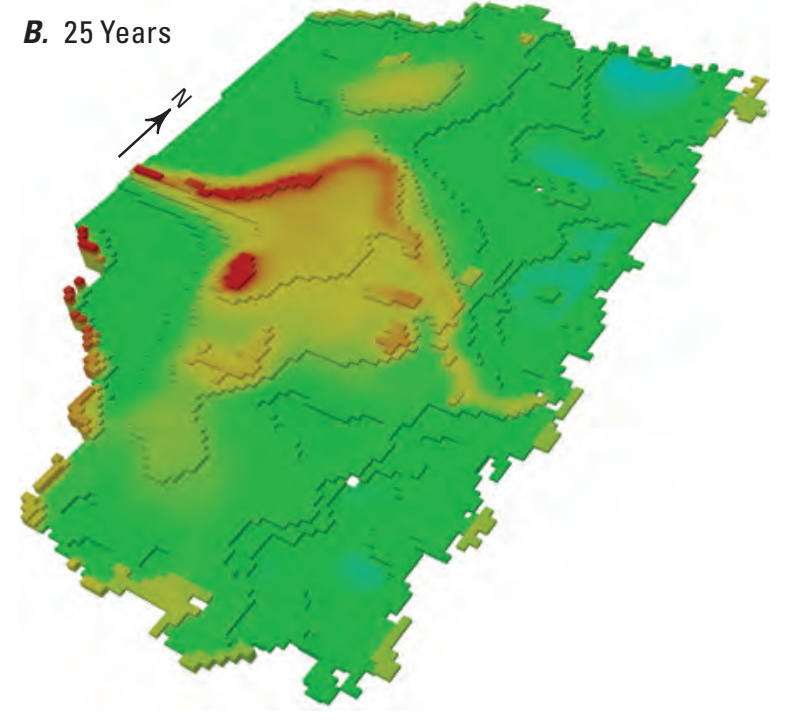

\section{50 Years}

Figure 57. Percent of aquifer that had less than or equal to 15 feet of saturated thickness at a pumping rate of 2.0 (acre-feet per acre) per year (scenario 2).

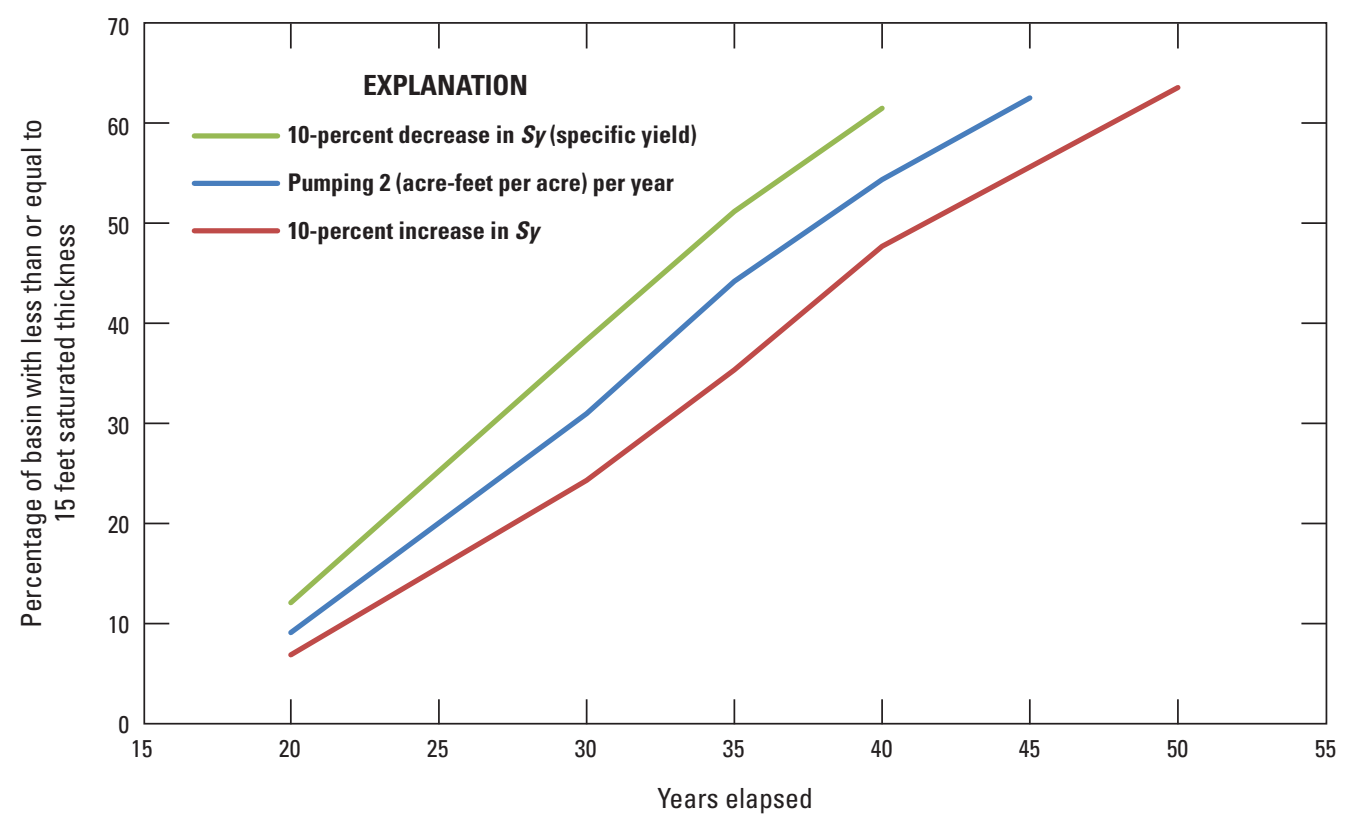

Figure 56. Central Oklahoma aquifer altitude of the water table (head) after 1,25 , and 50 years of pumping for the 2009-58 depletion-scenario simulation. (Model cells that go dry between each time step disappear from the surface of the model. Areas not depleted, in red, are beneath lakes and rivers). 
Table 11. Sensitivity of simulated heads to changes in parameters in the transient model.

\begin{tabular}{lcccc}
\hline \multirow{2}{*}{ Parameter } & \multicolumn{3}{c}{ Average change in head, in feet } \\
\cline { 2 - 5 } & 20-percent decrease & 10-percent decrease & 10-percent increase & 20-percent increase \\
\hline Horizontal hydraulic conductivity & 1.24 & 0.63 & -0.42 & -0.85 \\
Specific yield & -0.33 & -0.16 & 0.12 & 0.25 \\
Vertical anisotropy & 0.016 & 0.006 & -0.006 & -0.013 \\
Specific storage & 0.003 & 0.003 & 0.0003 & 0.003 \\
Recharge & -2.58 & -1.29 & 1.28 & 2.56 \\
\hline
\end{tabular}

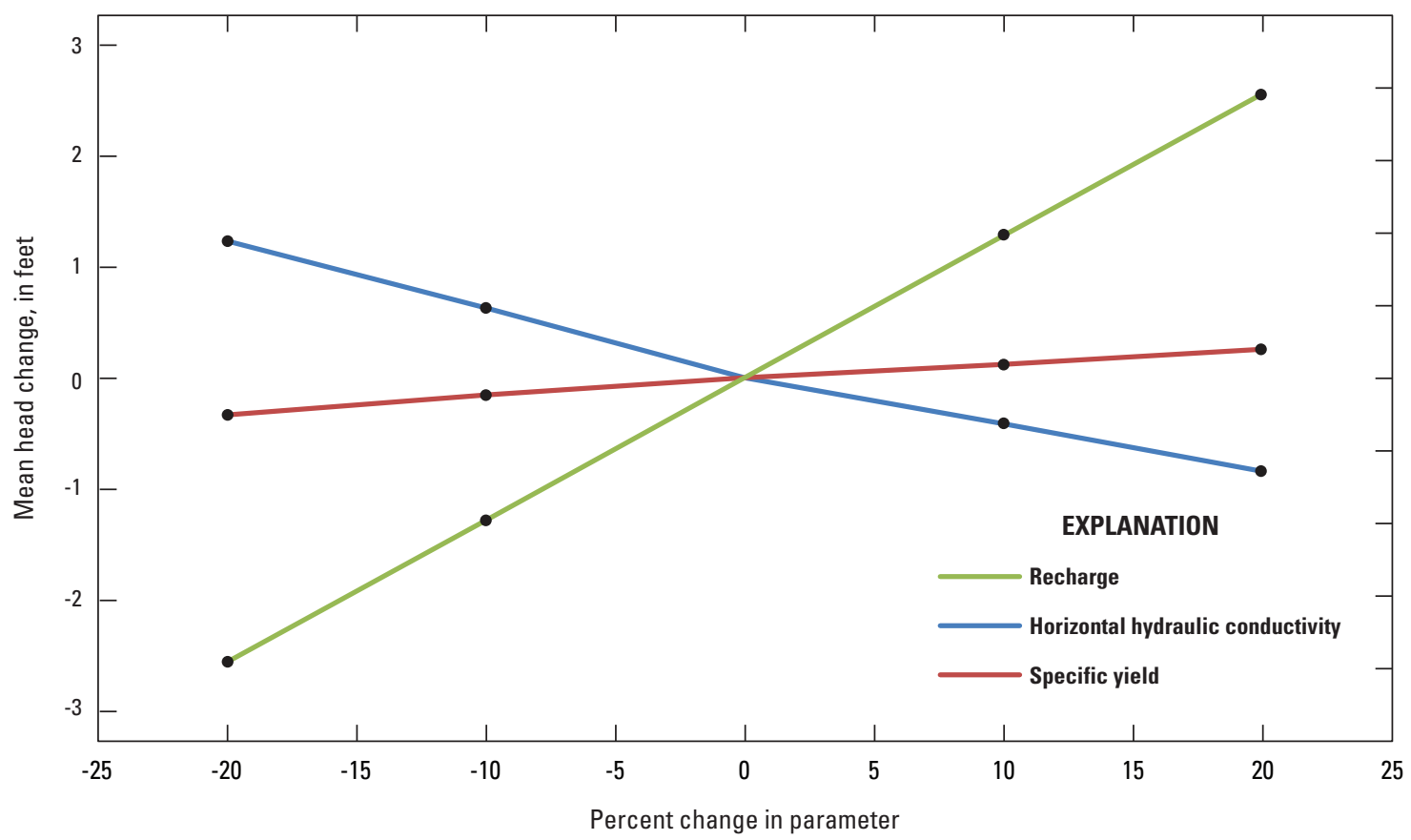

Figure 58. Changes in simulated heads at head targets in the transient model with percent changes in selected model parameters.

\section{Model Simplifications, Assumptions, and Limitations}

All models are generalizations of the systems represented and are based on assumptions with inherent limitations. The model presented herein is a regional-scale model that uses relatively large cells, and only includes large bodies of surface water. Thus, the model is limited by the spatial definition of the model grid. The model is limited in how detailed the interactions between the Central Oklahoma aquifer and surface water can be portrayed. This model also does not discretely distinguish between the alluvium and terrace deposits along the Cimarron, North Canadian, and Canadian Rivers and bedrock parts of the Central Oklahoma aquifer. These deposits are in the model and are represented by increased horizontal conductivity where detected by logs, such as along the North Canadian River east of the extent of the Hennessey Group. However, no water budget can be created by this model to estimate the flux of water between the alluvium and terrace aquifers and the Central Oklahoma aquifer.

The initial model run was a long-duration transient model that was run until there was little change in water in storage, indicating that the flow system was in equilibrium with the inflows and outflows defined for 1987. This is a quasi-steadystate model and there may be some differences between this model and a model run in steady-state mode.

The lithology of the Central Oklahoma aquifer is highly variable, with no continuous internal confining units or conductive zones. Vertical changes in hydraulic conductivity are 
much more variable than can be captured in 100-ft (30.48-m) layers. Thus, the model layers are constructed as an approximation of a complex natural system and the variation in conductivity was estimated using the vertical anisotropy in hydraulic conductivity. These simplifications limit what the model can simulate with regard to specific well drawdown and vertical gradients near wells or well fields. This model design assumes that the percent of sand in the formations as estimated from gamma-ray and lithologic logs was a reasonable starting point for estimating the horizontal hydraulic conductivity of the aquifer.

The reported groundwater-use data provided by the OWRB have several assumptions and estimated values. The method used to determine the domestic groundwater use was based on population changes. This method has limitations in the assumption that the rate of change in population served by domestic wells changes similarly to the rate of change in total population. In addition, exact amounts of reported groundwater use are unknown because wells are not metered or uses logged.

The flow model was calibrated to water-level observations. There was no attempt to calibrate to streamflow observations, which limits the use of this model to simulate daily or seasonal streamflows or effects to daily or seasonal streamflows. However, the model can be used to simulate long-term effects of pumping on water levels and annual streamflows.

To simulate the equal proportionate share approach with the model, a well must be placed in every cell and pumped at equal rates. Model cell sizes were 3,280 ft by $3,280 \mathrm{ft}(1 \mathrm{~km}$ by $1 \mathrm{~km}$ ), so by placing a well in each cell, the equal proportionate share of 2.0 (acre-ft/acre)/yr would indicate that the wells would have to pump at a rate of 494 (acre-ft/1 square-km model cell)/yr. The assumption for the depletion scenario is that wells completed in the aquifer could actually withdraw this large amount of water. The depletion scenario does not take into account low hydraulic conductivities that would prevent large amounts of water from being pumped. The depletion scenario pumps at high rates until there is $15 \mathrm{ft}$ of saturated thickness, a point at which the pumping shuts off. In addition, with only $15 \mathrm{ft}$ of saturated thickness remaining in some areas, saline water would most likely upcone or migrate into the freshwater zone (aquifer). This model does not account for potential saline migration that might limit the extent of freshwater or decrease the amount of freshwater.

The model presented in the investigation described in this report considers the base of freshwater to be a no-flow boundary. This approach could be problematic if groundwater from the aquifer were used at a high rate (depletion) near the freshwater/saline interface that could cause saline water to migrate upgradient near the base of freshwater or horizontally near the western extent of freshwater near the freshwater/saline interface. This model does not account for potential saline-water migration that might limit the extent of freshwater or decrease the amount of freshwater. The potential of saline-water migration could be modeled as part of future investigations for the aquifer, but would require some additional data collection and geochemical and variable-density modeling.

\section{Summary}

The Central Oklahoma (Garber-Wellington) aquifer underlies about 3,000 square miles of central Oklahoma and water from the aquifer is used for public, industrial, commercial, agricultural, and domestic supply of water. The study area for this investigation was the extent of the Central Oklahoma aquifer. With the exception of Oklahoma City, all of the larger communities in central Oklahoma rely either solely or partly on groundwater from this aquifer. The Oklahoma City metropolitan area, incorporating parts of Canadian, Cleveland, Grady, Lincoln, Logan, McClain, and Oklahoma Counties, has a population of approximately 1.2 million people, estimated from the 2010 census and is expected to increase by 20 percent from 2000 to 2030. Growing cities need to locate reliable water supplies to sustain their projected populations. As areas are developed for groundwater supply, increased groundwater withdrawals may cause decreases in long-term aquifer water storage. The U.S. Geological Survey, in cooperation with the Oklahoma Water Resources Board, investigated the hydrogeology and simulated groundwater flow in the aquifer using a numerical groundwater-flow model.

The purpose of this report is to describe an investigation of the Central Oklahoma aquifer that included analyses of the geology, hydrology, hydrogeologic framework of the aquifer, and construction of a numerical groundwater-flow model. The groundwater-flow model was used to simulate groundwater levels and for water-budget analysis. The calibrated transient model was used to evaluate changes in groundwater storage associated with increased future water demands.

The Central Oklahoma aquifer consists of Quaternaryage alluvium and terrace deposits and the Permian-age Garber Sandstone, Wellington Formation, and Chase, Council Grove and Admire Groups. Groundwater flows between these geologic units and many wells are completed in the study area in the Quaternary-age and Permian-age units. Alluvium and terrace deposits in the study area are composed of lenticular beds of unconsolidated or loosely consolidated clays, silt, sand, and gravel and are found along all of the major streams. In the study area, the Permian-age Garber Sandstone and Wellington Formation have similar lithologies and differentiating the two in surface outcrops and in the subsurface by geophysical logs or core samples is difficult. The investigation described in this report focuses more on the Permian-age units because water in the Quaternary-age alluvium and terrace is volumetrically a small fraction of water in the Permian-age units. The Garber Sandstone and Wellington Formation consist of cross-bedded, fine-grained sandstone with shale or mudstone interbedded. Stratigraphically below the Wellington Formation are the Chase, Council Grove, and Admire Groups that are composed of cross-bedded, fine-grained sandstone, shale, and thin 
limestone. The Permian-age Hennessey Group overlies the western part of the Central Oklahoma aquifer and consists of interbedded red shale, clay, and some siltstone or fine-grained sandstone. The Hennessey Group acts as a confining layer because of its small transmissivity.

Analysis of regional groundwater flows indicates that groundwater in the shallow, local flow systems discharges to nearby streams and the rate of flow and flux of water are greatest in these local flow systems. Flow in the deeper part of the aquifer is slower and flowlines are longer than in the shallow, local flow systems. In this deeper flow system, groundwater flows under small streams to discharge primarily to the Deep Fork and Little River. Flow in the Central Oklahoma aquifer is slowest in the confined part of the Garber Sandstone and Wellington Formation and in the less transmissive parts of the unconfined flow system, which includes part of the Chase, Council Grove, and Admire Groups. Groundwater in the confined part of the aquifer comes from recharge primarily from a small area of the unconfined part of the aquifer near $35^{\circ} 23^{\prime}$ latitude and $97^{\circ} 23^{\prime}$ longitude as seen in the mound of water on the potentiometric-surface maps.

Water levels were measured in 280 wells as part of this investigation between February 17, 2009, and March 13, 2009. The 2009 water levels, in feet below land surface, ranged from 3.1 to 233.7 , with a median of 35.8 feet. Water levels were measured in more than 300 wells between December 22, 1986, and April 24, 1987, and water levels, in feet below land surface, ranged from 1.5 to 177 with a median of 32 feet. Water levels from 2009 were compared to water levels from 1986-87. Wells in which there was a measurement for both the 1986-87 and 2009 time periods were compared (169 wells). A statistical test was done to determine if the 2009 water levels changed significantly from the 1986-87 water levels. This statistical test indicated that the 2009 depth-to-water measurements have increased from the 1986-87 depth-to-water measurements, and this increase is statistically significant. The difference in the median depth-to-water measurements for the two time periods was 3.75 feet. A water level decline of 3.75 feet multiplied by the area of the aquifer $(3,000$ square miles), multiplied by the minimum and maximum porosity expected for this aquifer (14 to 30 percent) resulted in a calculated change of water in storage from 1986-87 to 2009 that ranged from 1,008,000 to 2,160,000 acre-feet, assuming all water from aquifer storage came from the unconfined conditions. This loss in storage from the 1986-2009 period, when averaged per year, resulted in approximately 44,000 to 94,000 acre-ft/yr.

Water levels from wells in the Oklahoma Water Resources Board Mass Measurement Program and the U.S. Geological Survey National Water Information System databases indicate that water levels in shallow wells are affected by barometric-pressure changes, precipitation, and pumping from nearby shallow wells. Water levels in deeper wells in the aquifer had minimal response to precipitation and barometric-pressure changes, but respond to pumping from nearby deep wells.
Groundwater-use data were compiled and included public water suppliers, irrigators, industry, and businesses. Including estimated unreported groundwater use, average groundwater use from 1967 to 2008 was about 37,367 acre-feet/year with public-water supply consuming 23,367 acre-feet/year, or about 63 percent of the average annual reported and estimated unreported groundwater use. Domestic use was estimated by using the 1990 census long-form data and population change compared to 1980, 2000, and 2010 census data. Average estimated domestic groundwater use from the aquifer from 1980 to 2010 was about 13,752 acre-feet/year.

The major streams flowing across the Central Oklahoma aquifer are the Cimarron River, North Canadian River, and Canadian River. The flows in these streams are regulated by dams and increased by releases from sewage-treatment plants. Average daily mean streamflow in the study area ranged from $55.8 \mathrm{cubic}$ feet/second at streamflow-gaging station 07230000 Little River below Lake Thunderbird near Norman, Okla., for the period 1966-2009 to 255 cubic feet/second at streamflowgaging station 07242380 Deep Fork at Warwick, Okla., for the period 1988-2009. Discharges measured in January 2009 in the study area during base-flow conditions ranged from 0.23 cubic feet/second at streamflow-gaging station 07241570 Deer Creek near Newalla, Okla., to 4.46 cubic feet/second at streamflow-gaging station 07242378 Captain Creek near Wellston, Okla.

Recharge rates to the Central Oklahoma aquifer were estimated or calculated using a basin-scale base-flowdischarge method, a basin-scale recession-curve displacement (Rorabaugh) method, and a regional-scale method using the Soil-Water Balance code. Recharge rates calculated for the 2009 measurements ranged from 0.20 inches per year at Deer Creek near Newalla, Okla., streamflow-gaging station to 2.02 inches per year at Wildhorse Creek at Luther, Okla., streamflow-gaging station. Recharge rates calculated using the Rorabaugh method varied from 1.3 inches per year at the Little River near Tecumseh, Okla., to 4.1 inches per year at the Deep Fork near Arcadia, Okla. Average annual recharge from the Soil-Water Balance code for the gridded aquifer area for the 1987-2009 period was 4.6 inches. However, during model calibration, a scaling factor of 0.4 was applied to Soil-Water Balance recharge, which resulted in 1.84 inches per year of average annual recharge values for the gridded aquifer area for the 1987-2009 period.

Aquifer hydraulic properties were estimated from lithologic and geophysical well logs, and were measured at a site where a multiple-well aquifer test was completed for this investigation. Transmissivity from the aquifer test at a production well near Norman, Okla., determined as part of this study, was 220 square feet per day. Using the screened interval of 90 feet in the production well, the geohydrologic-unit hydraulic conductivity was 2.4 feet per day. Analytical model solutions indicated a leaky confined aquifer. The storage coefficient from the analytical solution was 0.0013 . This storage coefficient indicates that, even though the Central Oklahoma aquifer extends to land surface with a potentiometric 
surface below the top of the Central Oklahoma aquifer, the groundwater system acts as a confined system due to laterally extensive interbedded mudstone and large contrasts in vertical hydraulic conductivity.

The objective of developing the hydrogeologic framework of the Central Oklahoma aquifer system was to provide a three-dimensional representation of the lithologic variability of aquifer materials at a scale that captured the regional controls on groundwater flow for input to the groundwater-flow model. Lithologic logs and gamma-ray logs were converted to percent sand, which was used as a proxy in the estimation of initial hydraulic conductivity of the aquifer for the groundwater-flow model. Percent sand was interpolated between logs to spatially distribute percent sand across the study area.

Approximately 11,000 lithologic logs were used for the percent-sand analysis. Most of the lithologic logs maintained by the Oklahoma Water Resources Board are from shallow, domestic-use wells, which typically only penetrate to approximately 300 feet below land surface. Therefore, lithologic logs tend to over-represent the shallow aquifer and under-represent the deep aquifer. To simplify and standardize the lithologic logs, the lithologic descriptions for each depth interval were reclassified into one of four categories that were used to estimate the percent sand of each interval. Lithology was classified into four lithologic categories: mud, sandy mud, muddy sand, and sand, which can be conceptually simplified and quantified as a continuous series of textures from 0 percent sand (mudstone) to 100 percent sand (sandstone). As the Central Oklahoma aquifer uniformly consists of very fine to fine grained sand and moderately well to well sorted grains, percentages of sand were assumed to be linearly distributed across the four lithologic categories. Each lithologic category was assigned a percent sand using a multiplier. For example, the sand category was assigned a bin percent sand range of 100 to 75 percent sand and a midpoint of 87.5 percent sand. The midpoint of each bin was used as a percent-sand multiplier because the midpoint was considered an average percent sand for each bin. The sand multiplier was 87.5 percent sand, the muddy sand multiplier was 62.5 percent sand, the sandy mud multiplier was 37.5 percent sand, and the mud multiplier was 12.5 percent sand. The percent sand was summarized into a total percent sand for each lithologic log using a weighted average of the interval thickness.

Approximately 600 gamma-ray logs also were used for the percent-sand analysis. Most of the gamma-ray logs used for the analysis were from public-supply wells, and some oil and gas wells. Depths of the logs ranged from approximately 300 to 1,000 feet below land surface. The approach to classify percent sand from the gamma-ray data assumed that each gamma-ray log included at least one sand (87.5 percent sand) and at least one mud (12.5 percent sand). A sand was determined to be the minimum intensity on the gamma-ray log and a mud was determined to be the maximum intensity on the gamma-ray log. A sand, or minimum intensity gamma-ray, was assigned a value of 87.5 percent sand and a pure mud, or maximum intensity gamma-ray, was assigned a value of
12.5 percent sand. All of the gamma-ray values between the minimum and maximum were scaled relative to the position of the value between the 12.5 and 87.5 percent sand. This scaling technique was independent of the units of measure and normalized the gamma-ray logs to make the logs more comparable. Gamma-ray data were stored at 0.5 -foot depth intervals and for consistency were summarized in the same manner as the lithologic-log data, with the same 4 bins of percent sand categories and the same maximum (87.5 percent) and minimum percent sand (12.5 percent). All data points were assigned one of four multipliers corresponding to the midpoint of each bin. Next, these multipliers were summarized for each log by using a weighted average of the interval thickness.

To spatially distribute the percent sand for the hydrogeologic framework, the data points of lithologic-log percent sand and gamma-ray log percent sand were incorporated into a Geographic Information System. For spatial interpolations at different depth intervals, each lithologic log was represented by a single percent sand value. However, for gamma-ray logs, multiple percent-sand values at 0.5 -foot intervals were averaged for each interval thickness to be interpolated. An inverse distance-weighted interpolation method was used to estimate percent sand for locations without logs. The gammaray percent sand and the lithologic-log percent sand were used to interpolate percent sand between log locations, but preference was given to gamma-ray-derived percent sand because gamma-ray logs were more detailed with depth.

A MODFLOW groundwater-flow model was developed to simulate groundwater flow and build water budgets in the Central Oklahoma aquifer. The Central Oklahoma aquifer was simulated using a grid comprised of 3,280-feet by 3,280-feet (1-kilometer by 1-kilometer) cells and 11 horizontal layers, each 100-feet thick (30.48 meters). The quasi-steady-state model was run to simulate the 1987 calendar year with equilibrium in flow and minimal changes in storage. Initial hydraulic conductivity used for the groundwater-flow model ranged from 0.33 to 3.3 feet per day and was estimated for each model cell using the percent sand from the hydrogeologic framework. The quasi-steady-state model was calibrated to a subset of the 1986-87 water levels. Parameters that were adjusted to affect quasi-steady-state model calibration included hydraulic conductivity, vertical anisotropy, and recharge. Recharge for the groundwater-flow model was set to 0.4 multiplied by the Soil-Water Balance recharge estimate. There was no apparent horizontal or vertical spatial bias to model error and the residuals indicated that the simulated heads are slightly lower than the observed heads, but most residuals were near zero. These results indicate that there is random error in the model, a large component of which is related to the discretization that could not accommodate local variation in flow properties. The hydraulic heads in the aquifer have been well simulated using the spatial distribution of percent sand.

The transient groundwater-flow model was constructed to represent the period from 1987 through 2009. Because pumping rates for public water-supply wells were only available 
on annual intervals, each year was chosen as a stress period. The transient model was calibrated to all available water-level measurements for the aquifer during the period of the simulation (1987-2009). Parameters adjusted during the transient calibration process included the specific yield and specific storage of the aquifer, and the average annual recharge rate. The largest flux to the model is recharge, with water removed from storage, seepage from reservoirs, and water lost from the aquifer to streams being approximately equal to recharge. Outflow was dominated by base flow to streams and pumping from wells. Water was removed from storage to meet the total outflow which indicates the aquifer was in a deficit (losing water) during this period. At the end of the transient simulation (2009), the aquifer mean saturated thickness was about 392 feet and the aquifer mean transmissivity was about 1,057 square feet per day. The simulated available water in storage was about 98.676 million acre-feet.

The purpose of the 50-year predictive simulation was to estimate the change in groundwater in storage if water use continues for 50 years at 2009 rates. The 50 -year predictive simulation used the same model inputs as the calibrated transient model except for recharge and pumping. Because this study did not attempt to simulate effects from a predictive climate model, recharge was held constant at the average flux for each cell that was specified for the 1987-2009 time period. Pumping was held constant at the 2009 average daily discharge for each well. To estimate the effects to water levels in the aquifer by the 2009 pumping rate continuing for 50 years, the model was run without any pumping, and then run with pumping. The difference in hydraulic heads and water in storage between those model runs was used to estimate the effect of pumping to storage in the aquifer. Pumping at the 2009 rate for 50 years with constant recharge resulted in drawdown in upland areas and reduction of water in storage. The recharge rate was substantially larger than the total pumping rate, but water discharge to streams combined with pumping created a deficit that was met by releasing water from aquifer storage and decreasing base flow to streams.

The calibrated transient model also was run to determine how much water could hypothetically be extracted from the Central Oklahoma aquifer in a 50-year period (scenario 1), and the effects of pumping the temporary state-apportioned rate of 2.0 (acre-feet/acre)/year (scenario 2). The purpose of this analysis was to provide estimates of the amount of water in storage in the Central Oklahoma aquifer. These scenarios were used to simulate the equal proportionate share by placing a well in every model cell and pumping at a constant rate. The first scenario determined the discharge rate at which wells placed in every model cell would have to be pumped so that just 15 feet (4.57 meters) or less of saturated thickness remained in 50 percent of the aquifer area ( 50 percent of the model cells) after 50 years. The second scenario was to pump 2 (acre-feet/acre)/year from every model cell, and to determine the time at which one-half of the aquifer area was reduced to 15 feet or less of saturated thickness. For scenario 1, the pumping rate at all cells that reduced the saturated thickness in one-half of the cells to or below 15 feet (4.57 meters) after 50 years was between 1.1 and 1.5 (acre-feet/acre)/year. The results of scenario 2 indicate the aquifer would be 50 percent depleted after between 35 and 41 years of pumping 2.0 (acre-feet/acre)/year using 10 percent increase and decrease in specific yield. This analysis indicates that scenario 2 pump-ing rate of 2.0 (acre-feet/acre)/year is not sustainable for more than 41 years if every landowner with a potential well in each acre in the Central Oklahoma aquifer exercised their tempo-rary right to pump at that rate.

\section{Selected References}

Abbott, B.N., 2005, Subsurface geology of arsenic-bearing Permian sedimentary rocks in the Garber-Wellington interval of the Central Oklahoma aquifer, Cleveland County, Oklahoma: Master's thesis, Oklahoma State University, p. 112 .

Agarwal, R.G., 1980, A new method to account for producing time effects when drawdown type curves are used to analyze pressure build up and other test data: Presented at the Society of Petroleum Engineers Annual Technical Conference and Exhibition, Sept.21-24, Dallas, Texas, SPE paper 9289.

Babbitt, H.E., and Doland, J.C., 1955, Water supply and engineering: New York, McGraw-Hill, 608 p.

Becker, C.J., Overton, M.D., Johnson, K.S., and Luza, K.V., 1997, Geologic and hydraulic characteristics of selected shaly geologic units in Oklahoma: U.S. Geological Survey Water-Resources Investigations Report 96-4303, 25 p.

Benham Engineering Company, Inc., and Black \& Veatch, 1967, Comprehensive report and master plan of water works improvements for the city of Oklahoma City, Oklahoma: $183 \mathrm{p}$.

Bingham, R.H., and Moore, R.L., 1975, Reconnaissance of the water resources of the Oklahoma City quadrangle central Oklahoma: Oklahoma Geological Survey Hydrologic Atlas 4, 4 sheets, scale 1:250,000.

Breit, G.N., 1998, The diagenetic history of Permian rocks in the Central Oklahoma Aquifer: U.S. Geological Survey Water-Supply Paper 2357-A, p. 45-67.

Breit, G.N., Rice, C.A., Esposito, K.J., and Schlottmann, J.L., 1990, Mineralogy and petrography of Permian rocks in the Central Oklahoma Aquifer: U.S. Geological Survey OpenFile Report 90-678, 50 p.

Bureau of Reclamation, 1958, Norman Project, Oklahoma: House Document 420, 85th Congress, 2nd Session, 146 p. 
Butler, J.J., Jin, W., Mohammed, G.A., and Reboulet, E.C., 2011, New insights from well responses to fluctuations in barometric pressure: Ground Water, v. 49, no. 4, p. 525-533.

Carr, J.E., and Marcher, M.V., 1977, A preliminary appraisal of the Garber-Wellington aquifer southern Logan and northern Oklahoma Counties Oklahoma: U.S. Geological Survey Open-File Report 77-278, 23 p.

C.H. Guernsey \& Co., 1959, Additional water supply, proposed surface-water reservoir on Little River, Norman Project, for cities of Norman, Midwest City, Del City: Oklahoma City, C.H. Guernsey \& Co.

Christenson, S.C., and Carpenter, L.K., 1992, Ground-water quality of the central Oklahoma (Garber-Wellington) Aquifer conference; proceedings: U.S. Geological Survey Open-File Report 92-116, 24 p.

Christenson, S.C., Morton, R.B., and Mesander, B.A., 1992, Hydrogeologic maps of the Central Oklahoma Aquifer, Oklahoma: U.S. Geological Survey Hydrologic Investigations Atlas HA-724, 3 sheets, scale 1:250,000.

Domenico, P.A., and Schwartz, F.W., 1998, Physical and chemical hydrogeology (2d): New York, N.Y., John Wiley \& Sons, Inc., 528 p.

Driscoll, F.G., 1986, Groundwater and Wells (2d ed.): St.Paul, Minn., Johnson Filtration Systems, 1,089 p.

Esri, 2007, Implementing Inverse Distance Weighted (IDW), Release 9.2, accessed on January 20, 2012, at http://webhelp.esri.com/arcgisdesktop/9.2/index. cfm?TopicName=Implementing\%20Inverse \%20Distance $\% 20$ Weighted $\% 20$ (IDW).

Fetter, A.W., 1994, Applied hydrogeology (3d ed.): Upper Saddle River, N.J., Prentice-Hall, 691 p.

Gates, M.M., Marsh, J.H., and Fryberger, J.S., 1983, Technical considerations for the development plan of the GarberWellington aquifer: Norman, Oklahoma, Engineering Enterprises, Inc., v. 1, p. IV-33.

Gesch, D.B., 2007, The National Elevation Dataset, in Maune, David, ed., Digital elevation model technologies and applications: The DEM Users Manual, 2nd Edition: Bethesda, Maryland, American Society for Photogrammetry and Remote Sensing, p. 99-118.

Gould, C.N., 1905, Geology and water resources of Oklahoma: U.S. Geological Survey Water Supply and Irrigation Paper 148, 178 p.

Gromadzki, G.A., 2004, Outcrop-based gamma-ray characterization of arsenic-bearing lithofacies in the GarberWellington Formation, Central Oklahoma aquifer (Central Oklahoma aquifer), Cleveland County, Oklahoma: Master's thesis, Oklahoma State University, 232 p.
Hantush, M.S., 1960, Modification of the theory of leaky aquifers: Journal of Geophysical Research., v. 65, no. 11, p. 3713-3725.

Hantush, M.S., 1961a, Drawdown around a partially penetrating well: Journal of the Hydraulics Division, Proceedings of the American Society of Civil Engineering, v. 87, no. HY4, p. 83-98.

Hantush, M.S., 1961b, Aquifer tests on partially penetrating wells: Journal of the Hydraulics Division, Proceedings of the American Society of Civil Engineers, v. 87, no. HY5, p. 171-194.

Hantush, M.S., and Jacob, C.E., 1955, Non-steady radial flow in an infinite leaky aquifer: American Geophysical Union Transactions, v. 36, p. 95-100.

Harbaugh, A.W., 2005, MODFLOW-2005, The U.S. Geological Survey modular ground-water model-The GroundWater Flow Process: U.S. Geological Survey Techniques and Methods, book 6, chap. A16, variously paged.

Harbaugh, A.W., Banta, E.R., Hill, M.C., and McDonald, M.G., 2000, MODFLOW-2000, the U.S. Geological Survey modular ground-water model-User guide to modularization concepts and the Ground-Water Flow Process: U.S. Geological Survey Open-File Report 00-92, 121 p.

Hargreaves, G.H., and Samani, Z.A., 1985, Reference crop evapotranspiration from temperature: Applied Engineering in Agriculture, v. 1, no. 2, p. 98-99.

Hart, D.L., Jr., 1966, Base of fresh ground water in southern Oklahoma: U.S. Geological Survey Hydrologic Atlas HA-223, 2 sheets, scale 1:250,000.

Heran, W.D., Green, G.N., and Stoeser, D.B., 2003, A digital geologic map database for the state of Oklahoma: U.S. Geological Survey Open-File Report 2003-247, 12 maps.

Hill, M.C., Banta, E.R., Harbaugh, A.W., and Anderman, E.R., 2000, MODFLOW-2000, the U.S. Geological Survey modular ground-water model-User guide to the observation, sensitivity, and parameter-estimation processes and three post-processing programs: U.S. Geological Survey Open-File Report 00-184, 210 p.

Hydrosolve, Inc., 2011, Aqtesolv for Windows: Hydrosolve, Inc., accessed January 30, 2011, at http://www.aqtesolv. com.

Horizon Systems Corporation, 2010, National Hydrography Dataset Plus (NHDPlus): Horizon Systems Corporation, accessed November 1, 2010, at http://www.horizon-systems.com/nhdplus/.

Jacobsen, C.L., and Reed, E.W., 1949, Ground-Water supplies in the Oklahoma City area, Oklahoma: Oklahoma Geological Survey Mineral Report no. 20, 27 p. 
Kenney, K.M., 2005, Outcrop-based lithofacies and depositional setting of arsenic-bearing Permian red beds in the Central Oklahoma aquifer, Cleveland County, OklahomaMaster's thesis, Oklahoma State University, 299 p.

Kenny, J.F., Barber, N.L., Hutson, S.S., Linsey, K.S., Lovelace, J.K., and Maupin, M.A., 2009, Estimated use of water in the United States in 2005: U.S. Geological Survey Circular 1344, 52 p.

Keys, W.S., 1990, Borehole geophysics applied to groundwater investigations: U.S. Geological Survey Techniques of Water-Resource Investigation 02-E2, $150 \mathrm{p}$.

Konikow, L.F., Hornberger, G.Z., Halford, K.J., and Hanson, R.T., 2009, Revised multi-node well (MNW2) package for MODFLOW ground-water flow model: U.S. Geological Survey Techniques and Methods, book 6, chap. A30, 67 p.

Lindberg, F.A., ed., 1987, Correlation of stratigraphic units of North America (COSUNA) project, Texas-Oklahoma tectonic region: American Association of Petroleum Geologists, 1 sheet.

Lohman, S.W., 1972, Definitions of selected ground-water terms-Revisions and conceptual refinements: U.S. Geological Survey Water-Supply Paper 1988, 21 p.

Mashburn, S.L., and Magers, Jessica, 2011, Potentiometric surface in the Central Oklahoma (Garber-Wellington) aquifer, Oklahoma, 2009: U.S. Geological Survey Scientific Investigations Map 3147, 1 sheet, scale 1:24,000.

Mogg, J.L., Schoff, S.L., and Reed, E.W., 1960, Groundwater Resources of Canadian County, Oklahoma: Oklahoma Geological Survey Bulletin 87, $112 \mathrm{p}$.

Multi-Resolution Land Characteristics Consortium (MRLC), 2001, National Land Cover Database: U.S. Geological Survey, accessed August 22, 2011, at http://www.mrlc.gov/ nlcd01_data.php.

National Climatic Data Center, 2010, Locate Weather Observation Station Record: accessed July 14, 2010, at http:// www.ncdc.noaa.gov/oa/climate/stationlocator.html.

National Weather Service, 2011, What is the Coop Program?, accessed August 30, 2011, at http://www.weather.gov/om/ coop/what-is-coop.html.

Natural Resources Conservation Service, 2006, Digital general soil map of U.S., accessed October 13, 2009, at http://datagateway.nrcs.usda.gov/.

Neuralog, Inc., 2010, Automated Well Log Digitizing Software: accessed January 30, 2010, at $h t t p: / / w w w . n e u r a l o g$. com/pages/NeuraLog.html.
Niswonger, R.G., and Prudic, D.E., 2005, Documentation of the Streamflow-Routing (SFR2) Package to include unsaturated flow beneath streams-A modification to SFR1: U.S. Geological Survey Techniques and Methods book 6, chap. A16, 50 p.

Nkoghe-Nze, S.C., 2002, A reconnaissance study of controls on aquifer quality in the Central Oklahoma Aquifer: Master's thesis, Oklahoma State University, 68 p.

Oklahoma Climatological Survey, 2011a, The climate of Oklahoma County: accessed October 2011, at http://climate. ok.gov/county_climate/Products/County_Climatologies/ county_climate_oklahoma.pdf.

Oklahoma Climatological Survey, 2011b, Daily time series using cooperative observer (COOP) data: accessed June 8, 2011, at http://climate.ok.gov/index.php/climate/category/ my_county_or_town.

Oklahoma Climatological Survey, 2011c, Daily data retrieval, accessed October 2011, at http://www.mesonet.org/index. php/weather/daily_data_retrieval.

Oklahoma Department of Commerce, 2012, County and MSA population projections 2000-2030: accessed April 16, 2012, at http://www.okcommerce.gov/Data-And-Research/Downloads/Population-Projections.

Oklahoma Statutes Title 82 Section 1020.5, 2011, Determination of Maximum Annual Yield.

Oklahoma Water Resources Board, 2010, Taking and use of groundwater, Title 785, Chapter 30: accessed December 12, 2011, at http://www.owrb.ok.gov/util/rules/pdf_rul/ RulesCurrent2010/Ch30.pdf.

Oklahoma Water Resources Board, 2011, 2012 Oklahoma Comprehensive Water Plan August 2011 Draft Report on the Central Watershed Planning Region: 149 p.

Oklahoma Water Resources Board, 2013, Water Well Record Search, accessed January 1, 2013, at http://www.owrb. ok.gov/wd/search/search.php?type=wl.

Parkhurst, D.L., Christenson, S.C., and Breit, G.N., 1996, Ground-water-quality assessment of the Central Oklahoma Aquifer, Oklahoma; Geochemical and geohydrologic investigations: U.S. Geological Survey Water-Supply Paper 2357-C, $101 \mathrm{p}$.

Parkhurst, D.L., Christenson, S.C., and Schlottmann, J.L., 1989, Ground-water quality assessment of the Central Oklahoma Aquifer, Oklahoma; Analysis of available waterquality data through 1987: U.S. Geological Survey OpenFile Report 88-728, 80 p. 
Parkhurst, D.L., Christenson, S.C., and Schlottmann, J.L., 1994, Ground-water quality assessment of the Central Oklahoma Aquifer, Oklahoma; Analysis of available waterquality data through 1987: U.S. Geological Survey WaterSupply Paper 2357-B, 74 p.

Rasmussen, T.C., and Crawford, L.A., 1997, Identifying and removing barometric pressure effects in confined and unconfined aquifers: Ground Water, v. 35, no. 3, p. 502-511.

Reilly, T.E., 2001, System and boundary conceptualization in ground-water flow simulation: U.S. Geological Survey Techniques of Water-Resources Investigations, book 3, chap. B8, 26 p.

Risser, D.W., Gburek, W.J., and Folmar, G.J., 2005, Comparison of methods for estimating ground-water recharge and base flow at a small watershed underlain by fractured bedrock in the eastern United States: U.S. Geological Survey Scientific Investigations Report 2005-5038, 31 p.

Rorabaugh, M.I., 1964, Estimating changes in bank storage and groundwater contribution to streamflow: International Association of Scientific Hydrology, publication 63, p. $432-441$.

Runkle, D.L., Christenson, S.C., and Rea, Alan, 1997, Digital data sets that describe aquifer characteristics of the Central Oklahoma Aquifer in central Oklahoma: U.S. Geological Survey Open-File Report 96-454, 2 disks.

Rutledge, A.T., 1998, Computer programs for describing the recession of ground-water discharge and for estimating mean ground-water recharge and discharge from streamflow records-Update: U.S. Geological Survey Water-Resources Investigations Report 98-4148, 43 p.

Schlottmann, J.L., and Funkhouser, R.A., 1991, Chemical analysis of water samples and geophysical logs from cored test holes drilled in the Central Oklahoma aquifer, Oklahoma: U.S. Geological Survey Open-File Report 91-464, $58 \mathrm{p}$.

Schlottmann, J.L., Mosier, E.L., and Breit, G.N., 1998, Arsenic, chromium, selenium, and uranium in the Central Oklahoma Aquifer, in Christenson, Scott, and Havens, J.S., eds., Ground-water quality assessment of the Central Oklahoma Aquifer, Oklahoma-Results of investigations: U.S. Geological Survey Water-Supply Paper 2357-A, p.119-179.

Siemers, W.A., Stanley, T.M., and Suneson, N.H., 2000, Geology of Arcadia Lake parks-an introduction and field-trip guide: Oklahoma Geological Survey, Information Series 7, p. 3-9.
Smith, S.J., Paxton, S.T., Christenson, S.C., Puls, R.W., and Greer, J.R., 2009, Flow contribution and water quality with depth in a test hole and public-supply wells: Implications for arsenic remediation through well modification, Norman, Oklahoma, 2003-2006: Environmental Protection Agency 600/R-09/036, 57 p.

Spane, F.A., 2002, Considering barometric pressure in groundwater flow investigations: Water Resources Research, v. 36, no. 6, p. 1078-1095.

Stanton, J.S., Ryter, D.W., and Peterson, S.M., 2012, Effects of linking a soil-water-balance model with a groundwater-flow model: Ground Water, v. 51, no. 4, p. 613-622.

Steel, E.W., 1947, Water supply and sewerage: New York, McGraw-Hill, 666 p.

Stoner, J.D., 1984, Estimate of self-supplied domestic water use in Oklahoma during 1980: U.S. Geological Survey Water-Resources Investigations Report 83-4223, 20 p.

Szilagyi, Jozef, Harvey, F.E., and Ayers, J.F., 2003, Regional estimation of base recharge to ground water using water balance and a base-flow index: Ground Water, v. 41, no. 4, p. 504-513.

Tanaka, H.H., and Davis, L.V., 1963, Ground water Rush Springs sandstone in the Caddo County Area, Oklahoma: Oklahoma Geological Survey Circular 61, 63 p.

Theis, C.V., 1935. The relation between the lowering of the piezometric surface and the rate and duration of discharge of a well using groundwater storage: American Geophysical Union Transactions, v. 16, p. 519-524.

Tortorelli, R.L., 2009, Water use in Oklahoma 1950-2005: U.S. Geological Survey Scientific Investigations Report 2009-5212, 49 p.

Tucker, M.E., 1981, Sedimentary petrology an introduction: Blackwell Scientific Publications, Geoscience Texts, v. 3, $252 \mathrm{p}$.

University of Oklahoma Center for Spatial Analysis, 2013, accessed September 19, 2013, at http://geo.ou.edu/ DataFrame.htm.

U.S. Board on Geographic Names, 2013, Domestic and Antarctic Names - State and Topical Gazetteer Download Files: accessed August 1, 2013, at http://geonames.usgs.gov/.

U.S. Census Bureau, 2013, Census of Population and Housing: U.S. Census Bureau, accessed September 19, 2013, at http://www.census.gov/prod/www/decennial.html.

U.S. Census Bureau, 1990, 1990 Summary tape file 3 technical documentation, accessed September 19, 2013, at http:// www.census.gov/prod/www/decennial.html. 
U.S. Census Bureau, 2001, Redistricting Census TIGER/Line Files, accessed September 19, 2013, at http://www.census. gov/geo/maps-data/data/tiger.html.

U.S. Department of Agriculture, 2004, Hydrology-USDANRCS National Engineering Handbook, Part 630, Chapter 9: Washington D.C., 14 p.

U.S. Geological Survey, 2010a, Water-resources data for the United States, water year 2009: U.S. Geological Survey Water-Data Report WDR-USGS-2009, accessed November 21, 2011, at http://wdr.water.usgs.gov/wy2009/search. jsp.

U.S. Geological Survey, 2010b, National Water Information System data available on the World Wide Web (Water Data for the Nation), accessed November 21, 2009, at http:// waterdata.usgs.gov/nwis/.

Westenbroek, S.M., Kelson, V.A., Dripps, W.R., Hunt R.J., and Bradbury, K.R., 2010, SWB-A modified Thornthwaite-Mather Soil-Water-Balance code for estimating groundwater recharge: U.S. Geological Survey Techniques and Methods, book 6, chap. A31, 60 p.

Wickersham, G., 1979, Ground water resources of the southern part of the Garber-Wellington ground water basin, in Cleveland and Southern Oklahoma Counties and parts of Pottawatomie County, Oklahoma: Oklahoma Water Resources Board, Hydrologic Investigations Publication 86, 3 sheets, scale 1:380,160.

Wilcoxon, F., 1945, Individual comparisons by ranking methods: Biometrics Bulletin, v. 1, no. 6, p. 80-83.

Wood, P.R., and Burton, L.C., 1968, Ground-water resources in Cleveland and Oklahoma Counties, Oklahoma: Oklahoma Geological Survey Circular 71, 75 p.

Ziegler, A.M., 1990, Phytogeographic patterns and continental configurations during the Permian Period, in McKerrow, W.S., and Scotese, C.R., eds., Paleozoic paleogeography and biogeography: The Geological Society of London Memoir no. 12, p. 363-379. 
Appendix 


\section{Appendix 1. Aquifer Test}

A multiple-well aquifer test was completed at a production well near Norman, Okla., as part of this report to determine transmissivity and a storage coefficient for the Central Oklahoma aquifer (fig. 1-1). The production well was completed to a depth of 530 feet below land surface and sealed to a depth of 265 feet. The production well was screened from 300 to 320 feet below land surface, 400 to 420 feet, 430 to 450 feet, 460 to 480 feet, and 500 to 510 feet with a screen diameter of 10.75 inches. There were three observation wells located near the production well that were completed at various depths. The deep observation well, located 45.5 feet from the production well, was completed to a depth of 460 feet below land surface and sealed to a depth of 415 feet. The deep observation well was screened from 430 to 460 feet below land surface with a diameter of 6 inches. The middle observation well was completed to a depth of 235 feet below land surface, screened from 205 to 225 feet with a diameter of 6 inches and sealed to 190 feet. The shallow observation well was completed to a depth of 170 feet below land surface, screened from 140 to 160 feet with a diameter of 6 inches and sealed to 125 feet. The production and observation wells are completed in the Garber Sandstone-Wellington Formation (undifferentiated) just to the east of the outcrop extent of the Hennessey Group (see geologic units on figs. 4 and 5 in the Geology of the Central Oklahoma Aquifer section of this report). The production-well pump was started at 10:30 AM on March 1, 2011. The pump ran at a rate of 190 gallons per minute for 7 days and shut off at 3:15 PM on March 8,
2011. Water levels to document recovery in the observation wells were measured from March 8 through March 16, 2011. Water-levels measured in the shallow and middle observation wells indicated that the pumping was not causing measurable drawdown in the water levels in those wells. Therefore, only the data from the deep observation well were analyzed for the aquifer test (fig. 1-2).

The aquifer test was analyzed by using the AQTESOLV software package (Hydrosolve, Inc., 2011). The depths of the production and observation wells with casing information were input to the AQTESOLV program to correct for partial penetration of the aquifer. Several model solutions were tried for the pumping period of the test, but the best fit was the Hantush for leaky confined aquifers solution (Hantush, 1960; Hantush, 1961a; and Hantush, 1961b) (fig. 1-3). Water levels from the recovery period of the test were matched and the best fit was the Hantush-Jacob for leaky confined aquifers solution (Agarwal, 1980; Hantush and Jacob, 1955) (fig. 1-4).

Transmissivity from the analytical solution was 220 square feet per day (fig. 1-3). Using the screened interval of 90 feet in the production well, the geohydrologic-unit hydraulic conductivity is 2.4 feet per day. The average percent sand of the Central Oklahoma aquifer at the location and of this aquifer test is approximately 70 percent. The storage coefficient from the analytical solution was 0.0013 (fig. 1-3), which is an order of magnitude higher than previously published storage coefficients for this aquifer.

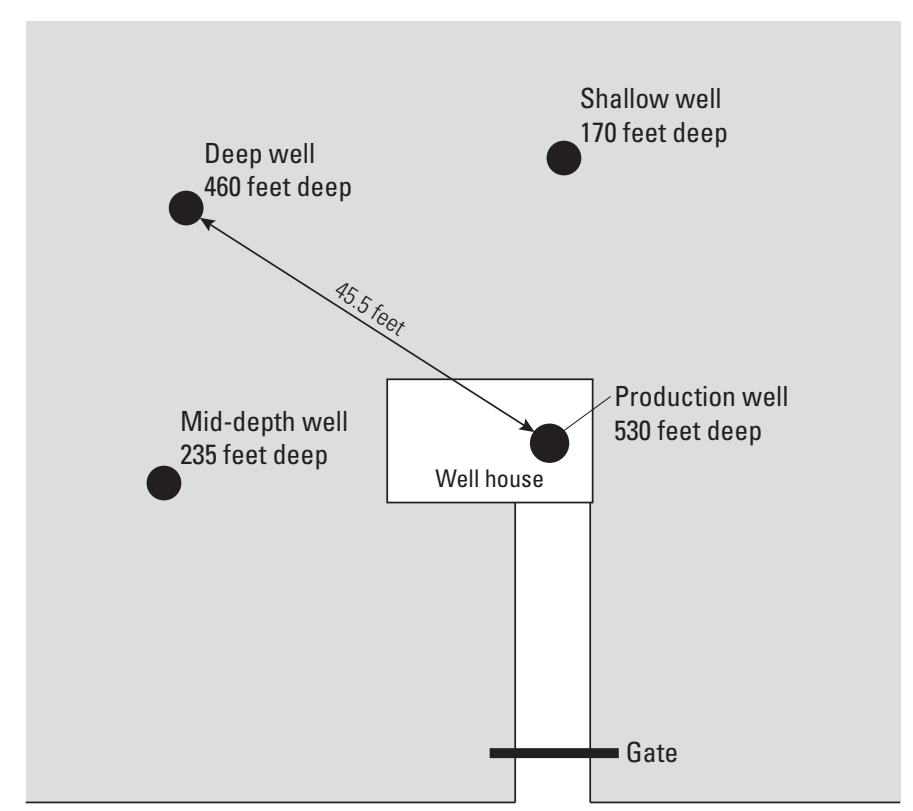

Figure 1-1. Layout of the aquifer test in the Central Oklahoma aquifer. (Not to scale). 

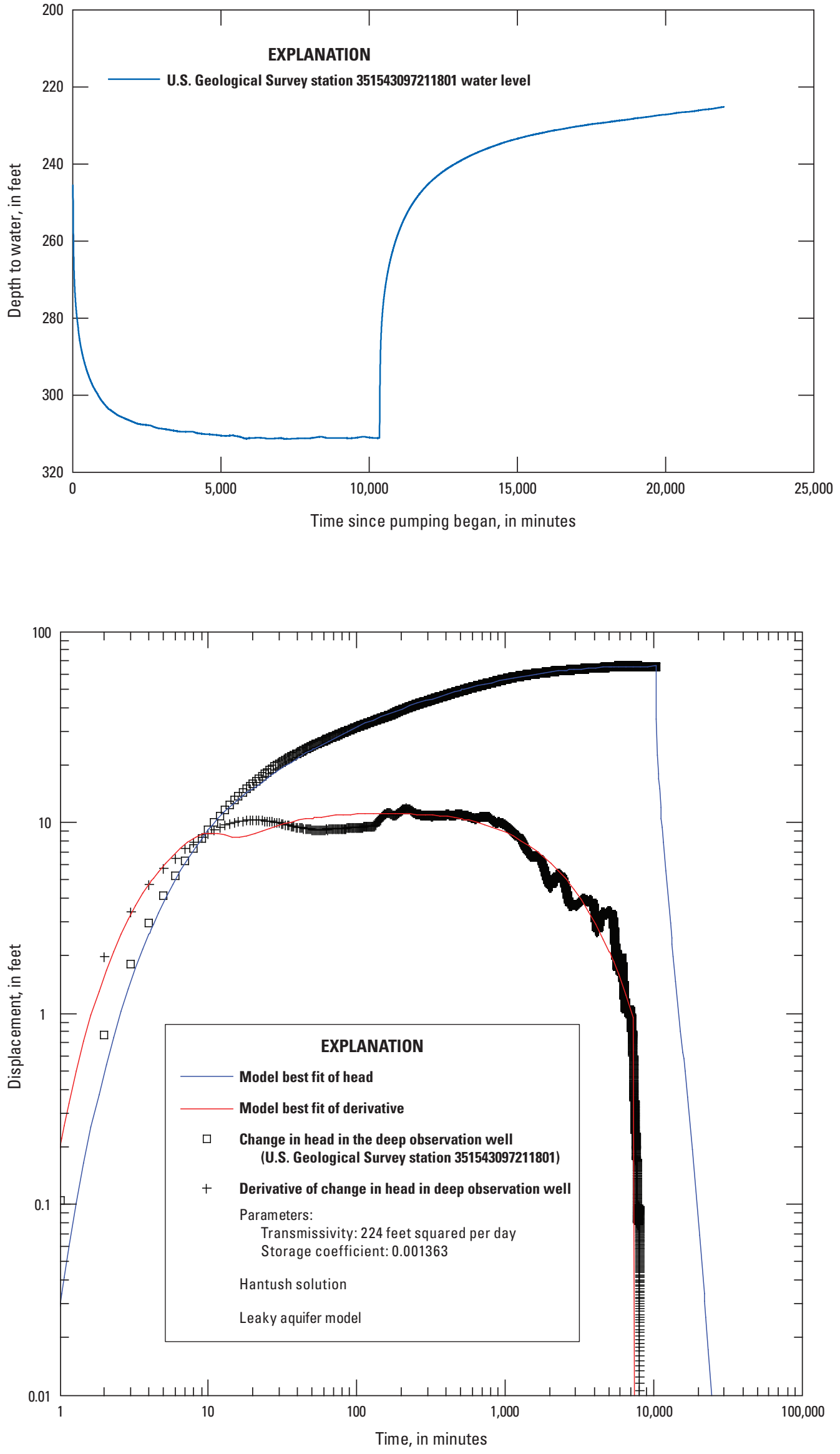

Figure 1-2. The deep observation well water-level during the pumping (March 1-8) and recovery periods (March 8-16) of the Norman aquifer test in the Central Oklahoma aquifer, 2011.
Figure 1-3. Pumping drawdown data curves and derivatives with best-fit Hantush method with aquitard storage solution for leaky confined aquifer analysis (Hantush, 1960). 


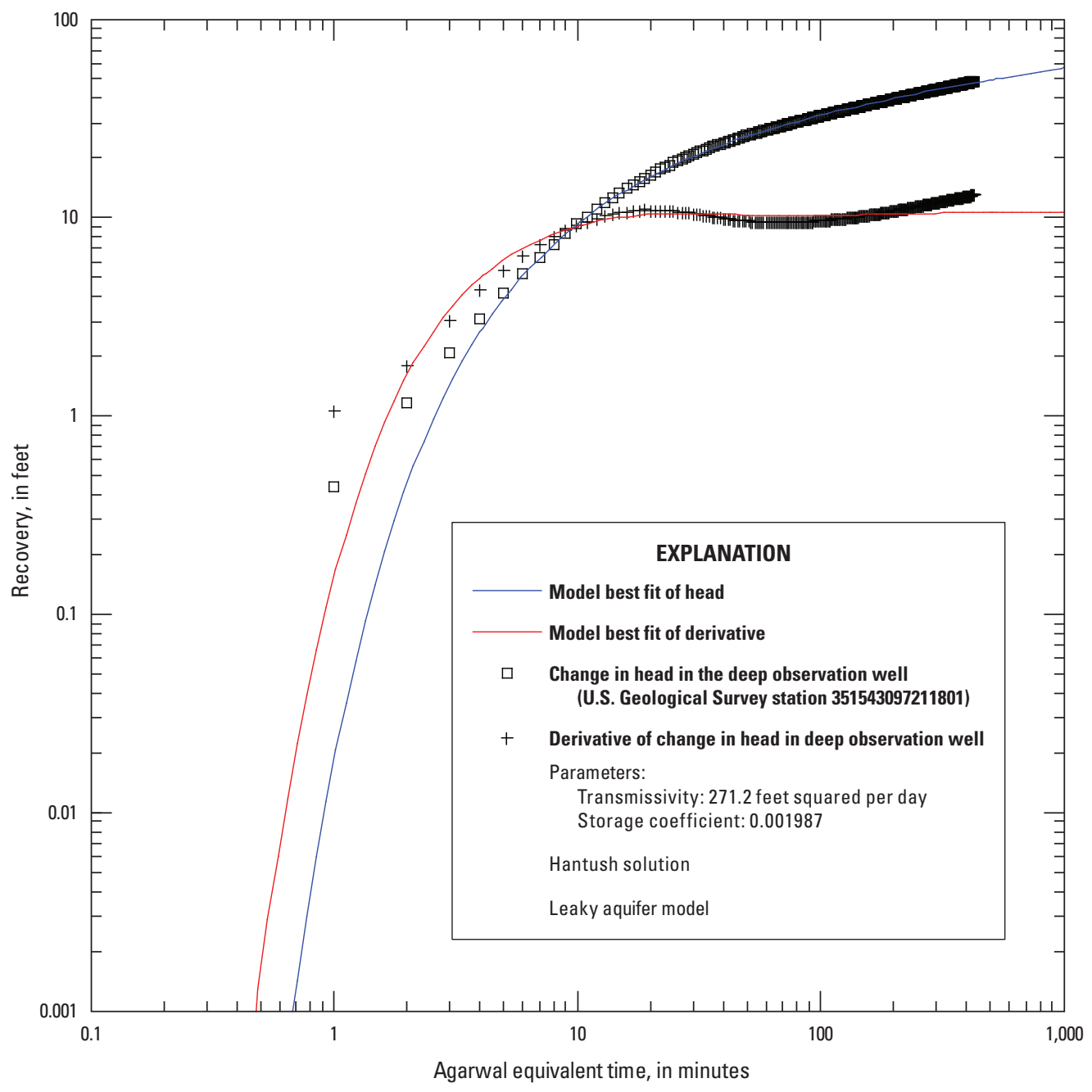

Figure 1-4. Water-level recovery data in Agarwal equivalent time with best-fit curve for the recovery analysis (Agarwal, 1980; Hantush and Jacob, 1955). 
Publishing support provided by:

Rolla and Lafayette Publishing Service Centers

For more information concerning this publication, contact: Director, Oklahoma Water Science Center U.S. Geological Survey

202 NW 66th St., Bldg. 7

Oklahoma City, Oklahoma 73116 (405) 810-4400

Or visit the Oklahoma Water Science Center Web site at: https://ok.water.usgs.gov/ 


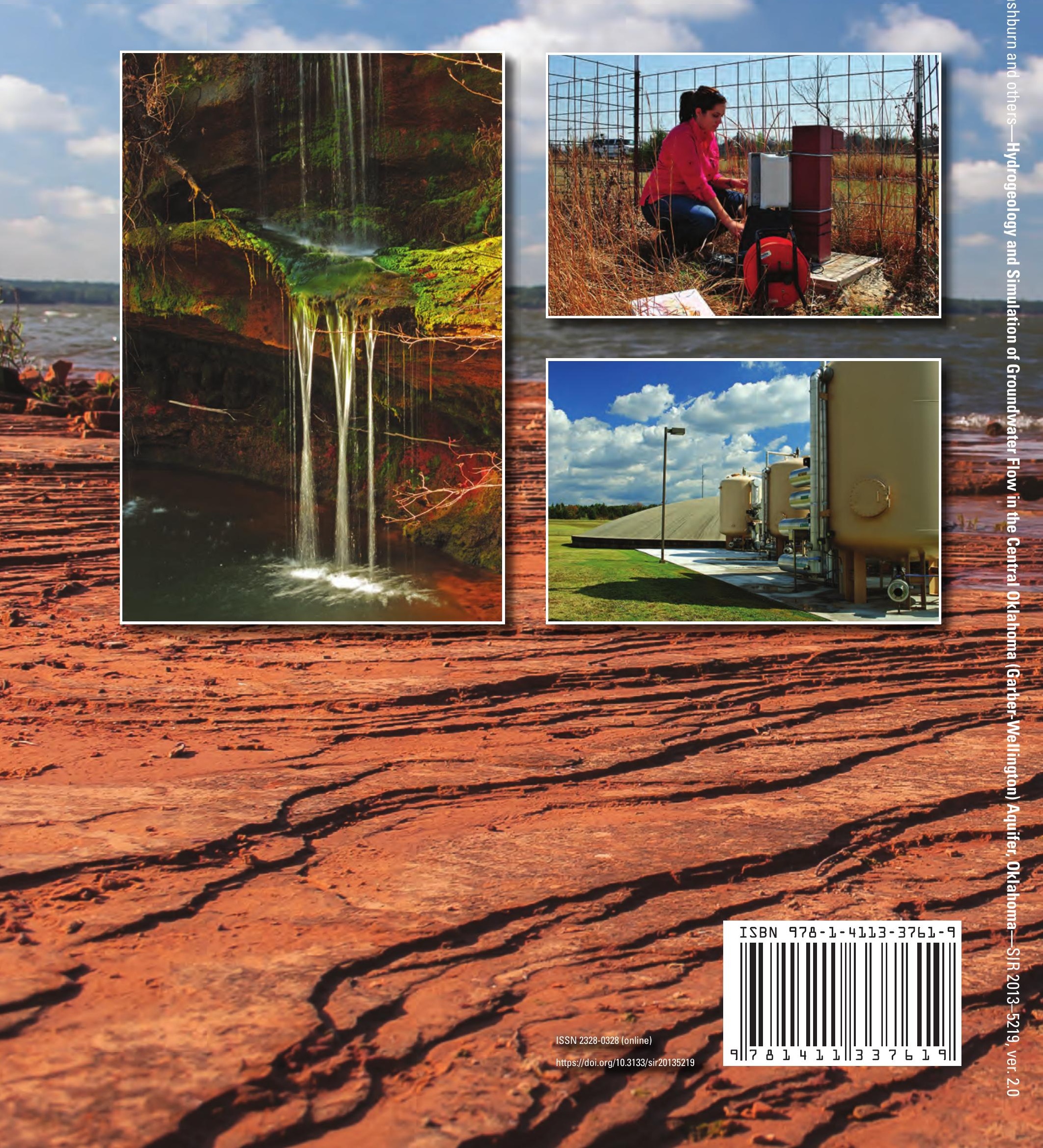

